\title{
Anti-Reflective Coating Materials: A Holistic Review from PV Perspective
}

\author{
Natarajan Shanmugam ${ }^{1}{ }^{\mathbb{D}}$, Rishi Pugazhendhi ${ }^{1}$, Rajvikram Madurai Elavarasan ${ }^{2, * \mathbb{D}}$, \\ Pitchandi Kasiviswanathan ${ }^{1}$ (D) and Narottam Das ${ }^{3,4}$ \\ 1 Department of Mechanical Engineering, Sri Venkateswara College of Engineering, Chennai 602117, India; \\ aspnatraj@gmail.com (N.S.); rishi2000.p@gmail.com (R.P.); pitch@svce.ac.in (P.K.) \\ 2 Department of Electrical and Electronics Engineering, Sri Venkateswara College of Engineering, \\ Chennai 602117, India \\ 3 School of Engineering and Technology, Central Queensland University, Melbourne, VIC 3000, Australia; \\ n.das@cqu.edu.au \\ 4 Centre for Intelligent Systems, School of Engineering and Technology, Central Queensland University, \\ Brisbane, QLD 4000, Australia \\ * Correspondence: rajvikram787@gmail.com
}

Received: 6 April 2020; Accepted: 15 May 2020; Published: 21 May 2020

\begin{abstract}
The solar photovoltaic (PV) cell is a prominent energy harvesting device that reduces the strain in the conventional energy generation approach and endorses the prospectiveness of renewable energy. Thus, the exploration in this ever-green field is worth the effort. From the power conversion efficiency standpoint of view, PVs are consistently improving, and when analyzing the potential areas that can be advanced, more and more exciting challenges are encountered. One such crucial challenge is to increase the photon availability for PV conversion. This challenge is solved using two ways. First, by suppressing the reflection at the interface of the solar cell, and the other way is to enhance the optical pathlength inside the cell for adequate absorption of the photons. Our review addresses this challenge by emphasizing the various strategies that aid in trapping the light in the solar cells. These strategies include the usage of antireflection coatings (ARCs) and light-trapping structures. The primary focus of this study is to review the ARCs from a PV application perspective based on various materials, and it highlights the development of ARCs from more than the past three decades covering the structure, fabrication techniques, optical performance, features, and research potential of ARCs reported. More importantly, various ARCs researched with different classes of PV cells, and their impact on its efficiency is given a special attention. To enhance the optical pathlength, and thus the absorption in solar PV devices, an insight about the advanced light-trapping techniques that deals with the concept of plasmonics, spectral modification, and other prevailing innovative light-trapping structures approaching the Yablonovitch limit is discussed. An extensive collection of information is presented as tables under each core review section. Further, we take a step forward to brief the effects of ageing on ARCs and their influence on the device performance. Finally, we summarize the review of ARCs on the basis of structures, materials, optical performance, multifunctionality, stability, and cost-effectiveness along with a master table comparing the selected high-performance ARCs with perfect AR coatings. Also, from the discussed significant challenges faced by ARCs and future outlook; this work directs the researchers to identify the area of expertise where further research analysis is needed in near future.
\end{abstract}

Keywords: antireflection coatings (ARCs); fabrication techniques; light trapping structures; nanostructures; nanotechnology; photovoltaics (PVs); power conversion efficiency 


\section{Introduction}

Light is an indispensable element in this colorful world, supporting both flora and fauna in every aspect. It is regarded as clean and renewable energy that also acts as a sustainable source of energy for the Photovoltaic (PV) cells. When light strikes the surface of an object, it gets reflected from the boundary between air and the surface of the object with different intensities. In the domain of photovoltaics, reflection becomes undesirable when light strikes the silicon wafer, and it adversely affects the availability of light for photovoltaic conversion. In general, a polished silicon surface would reflect more than $35 \%$ of incident light [1]. The maturation of effective light management strategies involving antireflection coatings and light-trapping structures has helped to enhance the performance of solar PV cells [2].

Antireflection coatings (ARCs) are predominantly utilized to suppress the Fresnel reflection losses when light propagates from one medium to another medium. Presently, there are two main strategies to achieve the antireflection effect: one is by depositing thin films such as a single-, double-, and multi-layer films on the substrate and the other strategy incorporates a graded refractive index (GRIN) coatings with the aid of porous and nanostructured arrays such as moth-eye structures [3-5]. The thin-film coating reduces the reflection occurring at different films through the destructive interference principle. Analyzing the optical properties and the mechanical stability of various anti-reflective (AR) thin-film coating configurations with different materials is crucial for obtaining a valid and high-performance antireflection coating. The latter approach of index matching reduces the reflection by progressively reducing the film refractive index from the index of refraction of the air to the index of refraction of the substrate, ensuring the maximum transmission of light. Also, the antireflection property is obtained by surface modification such as texturization [6-8]. By these methodologies, the light available for PV conversion can be significantly enhanced, and the outcome of which the performance of the solar cells is enhanced.

Nature has its way of developing antireflection properties in species by the process of evolution. The compound eyes of the insects like butterflies and moths possess a subwavelength structure (SWS) that remarkably imparted the antireflection effect on their corneal lens surface $[9,10]$. Similarly, natural structures having the potential to offer anti-reflectivity are found on the surface of the creatures, such as wings of cicadas, butterflies, and some marine organisms [11-15]. These SWSs provide varying refractive indexes from the air to the substrate, resulting in smooth propagation of the light such that reflection loss is close to zero. These biological structures paved the way for the development of state-of-art biomimetic antireflective coatings [16,17]. Also, these structures are robust, possess mechanical stability and durability owing to their geometric morphology and homogeneity of materials $[4,6]$. Extensive research had been carried out in this area, and various Gradient Refractive index (GRIN) nanostructures have been researched to improve the transmittance and to enrich the efficiency of photovoltaic power conversion [18-20]. The GRIN configuration is reported in many structures such as nanopillar [21,22], nanowire [23], nanorods [24,25], nano-cone [26,27], nanopyramid [28], and nanotip [29], and these structures are fabricated with a wide range of materials such as silicon, silicon dioxide, metal, metal oxides, polymers and even composites materials. Although these AR coatings exhibit high-performance in broad wavelength and possess omnidirectional antireflective qualities, the fabrication of such structures requires tedious efforts and still faces many problems. There exists a gap between durability and affordability owing to the limitations of fabrication procedures. Also, high optical performance is obtained only with the tradeoff between these factors. Hence, exploiting simple, cost-effective methodologies to fabricate such structures exhibiting high optical performance is the need of the hour.

The efficiency of the commercial crystalline silicon solar cells ranges between $12 \%$ and $19 \%$ and is expected to reach 20 to $23 \%$ by 2025 [30,31]. The PV technology is heading towards third-generation solar PV cells and most of solar panels in the market possess ARCs either on the PV device or on the glass cover. Hence, enhancing the optical performance of the ARC is very much essential to support the developments that are taking place in solar PV cells. However, with ageing and constant exposure 
to fluctuating environmental conditions, there exists a deterioration in the optical properties and the durability of the ARC [32,33]. Thus, research efforts are required to address the issues, and this review manuscript would highlight the existing solutions and provide a path to identify the potential areas where research efforts are required for further development.

Heretofore, some review works on antireflection coatings have been published [34-42], and Table 1 presents the outcome and future direction of research provided by various review works. The identified grey areas from the existing review works are as follows (Note that each work lacks only some of the topic mentioned below):

- Only commonly used ARC materials are reviewed.

- Analysis of the stability, durability, and environmental aspects of ARCs.

- AR coating's influence on the performance of the solar cells.

- AR coating's compatibility with solar cells and ageing effect.

- Impact of multifunctional coatings, Carbon Nanotube (CNT) coatings on solar cells.

- Environmental influence on the performance of bio-inspired coatings.

In this review work, we mainly focus on the developments in ARC materials over the past three decades from a PV standpoint and address most of the grey areas listed above. The outcome of this review work is as follows:

- Basic concepts of antireflection and strategies to achieve the same.

- Antireflective structures and surface analysis.

- Insight about state-of-art fabrication techniques used for various ARCs.

- A detailed review of antireflection coatings on the basis of various materials used covering the structure, fabrication methods, performance, features, and research potential.

- Coatings on PV cells and their influence on PCE.

- Novel light trapping techniques dealing with plasmonics, spectral modification, and innovative light-trapping structures approaching the Yablonovitch limit

- The ageing effect, the current status of AR technologies, best prospective coatings, challenges, and prospects.

Our review work mainly consists of ten sections. In the first section, the necessary background for understanding antireflection is discussed. The following section deals with antireflection coating structures and surfaces briefly. Then, the basics of various state-of-art fabrication techniques of ARCs are discussed. The proceeding fifth section contains a brief review of antireflection coating technologies based on various materials used. It covers material categories such as silicon-based, metal-based, polymer-based, composites, and other advanced materials. The table given under each mentioned material categories would give a crux of each research work considered along with suggestions for further development. The succeeding section elucidates the various antireflection coatings that are currently researched with different classes of PV cells and their impact on efficiency. Then, some advanced strategies used for trapping the light and increasing the optical pathlength in the solar cells are covered, which deals with the concept of plasmonics, spectral modification, and other potential innovative light-trapping structures having an absorption approaching Yablonovitch limit. Also, the ageing effect of ARCs and their impact on the PV device is briefed. Then, a crucial discussion is provided to summarize the developments that occurred in ARCs, and further, the best prospective coating is analyzed. The final section lists the significant challenges faced by ARCs, and the prospects are presented, accompanied by the conclusion. Regarding review methodology, research work for the past 30 years providing sufficient data of either reflectivity or transmittance in the observed wavelength range only is considered. 
Table 1. Various review works on antireflection coatings.

\begin{tabular}{|c|c|c|c|c|}
\hline YOP & Title of the Review Work & Outcome & Provided Future Direction of Research & Reference \\
\hline 2020 & $\begin{array}{l}\text { A review of anti-reflection and } \\
\text { self-cleaning coatings on } \\
\text { photovoltaic panels }\end{array}$ & $\begin{array}{l}\text { - Application of AR coatings on PV, various } \\
\text { methods of preparation, material and } \\
\text { surface aspects }\end{array}$ & $\begin{array}{l}\text { Provided only the review of } \\
\text { existing ARCs }\end{array}$ & [34] \\
\hline 2019 & $\begin{array}{l}\text { Recent developments in } \\
\text { multifunctional coatings for } \\
\text { solar panel applications: } \\
\text { A review }\end{array}$ & $\begin{array}{l}\text { - Self-cleaning and antireflective coatings for solar } \\
\text { panels with their light transparency } \\
\text { characteristics, surface morphology, electrical } \\
\text { conductivity, and wettability }\end{array}$ & $\begin{array}{l}\text { - Polymeric AR and self-cleaning } \\
\text { coatings developed using } \\
\text { aqueous methods. } \\
\text { - Smart hybrid coatings }\end{array}$ & [35] \\
\hline 2019 & $\begin{array}{l}\text { Ascendant bioinspired } \\
\text { antireflective materials: } \\
\text { Opportunities and } \\
\text { challenges coexist }\end{array}$ & $\begin{array}{l}\text { - The performance of bioinspired AR materials } \\
\text { - Advantages, disadvantages, and limitations of } \\
\text { various manufacturing techniques } \\
\text { Practical applications of ARC with } \\
\text { nanostructures array } \\
\text { - Challenges and opportunities of } \\
\text { bio-inspired ARC }\end{array}$ & $\begin{array}{l}\text { - Natural novel structures, materials, } \\
\text { and fabrication } \\
\text { Investigating a cost-effective, facile } \\
\text { industrial method to prepare } \\
\text { nano/micro-structured ARCs }\end{array}$ & [36] \\
\hline 2016 & $\begin{array}{l}\text { Highly efficient antireflective } \\
\text { and self-cleaning coatings that } \\
\text { incorporate carbon nanotubes } \\
\text { (CNTs) into solar cells: A review }\end{array}$ & $\begin{array}{l}\text { - } \quad \text { Incorporation of CNTs into PV cell } \\
\text { Fabrication techniques for antireflection and } \\
\text { self-cleaning coatings that include CNTs } \\
\text { Developments in AR and self-cleaning coatings } \\
\text { involving CNTs }\end{array}$ & $\begin{array}{l}\text { - } \quad \text { PCE comparison with allotropes of } \\
\text { carbon and CNTs } \\
\text { - } \quad \text { CNT-polymer composites as electrode } \\
\text { - } \quad \text { Exploring in detail the optical } \\
\text { characteristics of SWCNTs } \\
\text { and DWCNTs }\end{array}$ & [37] \\
\hline
\end{tabular}


Table 1. Cont.

\begin{tabular}{|c|c|c|c|c|}
\hline YOP & Title of the Review Work & Outcome & Provided Future Direction of Research & Reference \\
\hline 2016 & $\begin{array}{l}\text { Antireflective surface inspired } \\
\text { from biology: A review }\end{array}$ & $\begin{array}{l}\text { - } \quad \text { Development of bionic antireflective structures } \\
\text { proprication techniques and the antireflective } \\
\text { - The challenge and prospects involved in } \\
\text { bio-inspired structures }\end{array}$ & $\begin{array}{l}\text { - Optimization of } \\
\text { materials performance } \\
\text { Environment-friendly and cheaper } \\
\text { fabrication technology }\end{array}$ & [38] \\
\hline 2016 & $\begin{array}{l}\text { Superhydrophobic surfaces } \\
\text { with antireflection properties for } \\
\text { solar applications: A critical } \\
\text { review }\end{array}$ & $\begin{array}{l}\text { - } \quad \text { Concepts of AR and self-cleaning coatings } \\
\text { Briefing AR surfaces with } \\
\text { superhydrophobic properties } \\
\text { - Mechanism and fabrication pathways of } \\
\text { superhydrophobic and antireflective coatings } \\
\text { - Challenges and future prospects }\end{array}$ & $\begin{array}{l}\text { - Surface formation mechanism and the } \\
\text { composition, structure, and properties } \\
\text { relationship analysis } \\
\text { Exploring cost-effective fabrication } \\
\text { techniques for preparing high } \\
\text { mechanical strength, } \\
\text { abrasion-resistant ARCs }\end{array}$ & [39] \\
\hline 2014 & $\begin{array}{l}\text { Recent progress in antireflection } \\
\text { and self-cleaning } \\
\text { technology-From surface } \\
\text { engineering to functional } \\
\text { surfaces }\end{array}$ & $\begin{array}{l}\text { - The basic principle, fabrication strategies and } \\
\text { material aspects of self-cleaning AR coatings } \\
\text { The practical applications of self-cleaning ARCs } \\
\text { with future development }\end{array}$ & $\begin{array}{l}\text { - Theoretical simulation to reveal the } \\
\text { fabrication mechanism and to relate } \\
\text { composition, structure, and properties } \\
\text { Environmental issues-oriented } \\
\text { research for ARCs }\end{array}$ & [40] \\
\hline 2011 & $\begin{array}{l}\text { Anti-reflective coatings: } \\
\text { A critical, in-depth review }\end{array}$ & $\begin{array}{l}\text { - Strategies adopted for attaining antireflection } \\
\text { and types of ARCs } \\
\text { - } \quad \text { Various fabrication methods and materials used } \\
\text { - Challenges in AR coatings }\end{array}$ & $\begin{array}{l}\text { - } \quad \text { Research towards decreasing the gap } \\
\text { between affordability and durability }\end{array}$ & [41] \\
\hline 2010 & $\begin{array}{l}\text { Anti-reflecting and photonic } \\
\text { nanostructures }\end{array}$ & $\begin{array}{l}\text { - } \quad \text { Structure and surface analysis of ARCs } \\
\text { - } \quad \text { Design and construction of } \\
\text { - } \quad \text { Mhotonic nanostructures } \\
\text { Material aspects and future trends of ARC }\end{array}$ & $\begin{array}{l}\text { - Antireflection coatings on deformable } \\
\text { substrates and the application } \\
\text { of CNTs }\end{array}$ & [42] \\
\hline
\end{tabular}




\section{Framework}

Tons of data and efforts are required in building-up a review work on any expertise of research. Hence, the authors together discussed and made sure the topics that are to be covered in this study. Then, the sequence of execution for collecting the data on decided topics is framed. Initially, the works related to antireflection coatings are identified by using keyword searches across the various journal and publisher platforms such as Elsevier, Google scholar, and IEEE. A lot of work is revealed, and the initial screening is done by analyzing the title of the work. By doing so, a total of around 3300 were works identified, and then the subsequent scrutinizing works were carried out. Qualified information for the core area of study (ARC materials and ARCs on PV) is first scrutinized, and then the particulars for the remaining section is investigated. The first scrutinizing stage involves filtering the identified works with the information provided in the abstract and the conclusion. The second scrutinizing stage involves scanning for specific pre-decided data, and this data may vary from topic to topic. After this, the third scrutinizing stage is accomplished by skimming the whole content of the filtered work. Now, the filtered work is investigated for novel methods, results, prospects and is decided whether the work is to be reviewed in our study or not. Novel materials, innovative methods, and high performance blended with cost-effectiveness are some criteria required for a work to be considered for review in our study. Some scrutinized work contains or proves salient concepts, and research information suitable for supporting the review process is also considered. These are the process incorporated for the finalization of the filtered work, and thus, each finalized work is either used for reviewing or for supporting the review. The flow diagram of the literature survey process and the sequence of the manuscript work is represented in Figure 1. For instance, searching with the keyword "antireflection coatings (ARCs)" on google scholar would yield thousands of articles $(73,600)$. For a sub-section, Silicon-based antireflection coatings, the initial screening is executed by analyzing the title containing silicon-based ARCs. The first scrutinizing stage is carried out with the information extracted from the abstract and conclusion. Then, transmittance or reflectance data in an effective wavelength range is scanned to accomplish the second stage of scrutinizing. For the third stage, the entire content of the filtered work is skimmed to grasp the content, after which the finalization is done by the parameters mentioned earlier.

Apart from the core area of review, other sections in our study are required for supporting the core review area. Thus, the scrutinization and subsequent finalization process for these sections were aimed to provide crystal-clear conceptual knowledge that would help in interpreting the information presented in the core review section. As a whole, we have identified around 4100 works after initial screening from which, almost 1850 works have been scrutinized (stage 1). After the scrutinization process (stage $2 \& 3$ ), the filtered work was about 555 . Then, the subsequent finalization process yielded a total works of 407, which include 371 research works from various reputed journals, 25 review works, 3 online sources, and 8 conference proceedings. 


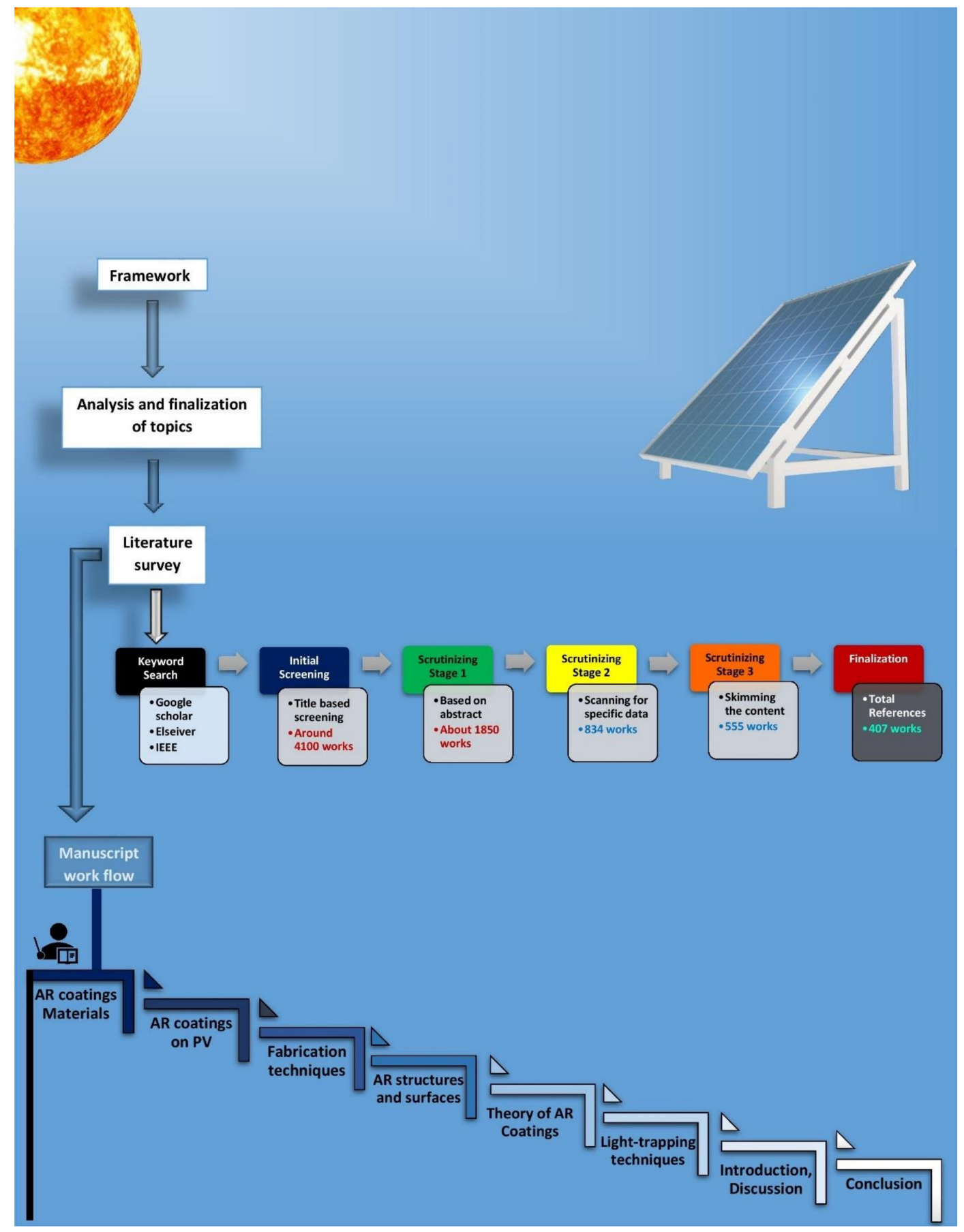

Figure 1. The framework of the study.

\section{Theory of Antireflection}

The reflection is an optical phenomenon that prevails when the light suddenly interfaces another medium resulting in a change of direction of the wave-front. The characteristics of a transparent medium are described by an optical parameter, known as a refractive index, which usually relates the light speed in the propagating medium and light speed in the vacuum. When there is an upheaval in the index of refraction, an optical interruption is produced, meaning, a small part of the incident light is diverted in the form of reflection (ignoring the scattering and absorption effects), and this phenomenon is termed as Fresnel reflection loss. The fragment of light rays that are bounced back is known as reflectance $(R)$, while the remaining transmitted light is termed as transmittance. And the 
refractive index is the dominating guiding variable that is responsible for determining the degree of light transmittance through the medium.

The principle behind the antireflection coating can be perceived from a single dielectric thin film with a refractive index, $n$ lower than that of the substrate having a refractive index, $n_{\mathrm{s}}$ (i.e., $n<n_{\mathrm{s}}$ ). This thin film configuration has two interfaces, causing the emergence of two reflected waves, as represented in Figure 2a. When these two reflected wave-fronts are completely out of phase, destructive interference takes place, canceling out both the rays entirely and thus enhancing the transmittance. The requirements for eliminating the reflected waves are: (i) The two reflected waves must be exactly 180 degrees out of phase and should be of the same intensity after reflecting at two interfaces. (ii) The film depth should be an odd number multiple of one-fourth of the incident beam wavelength $(\lambda / 4)[41]$.

(a)

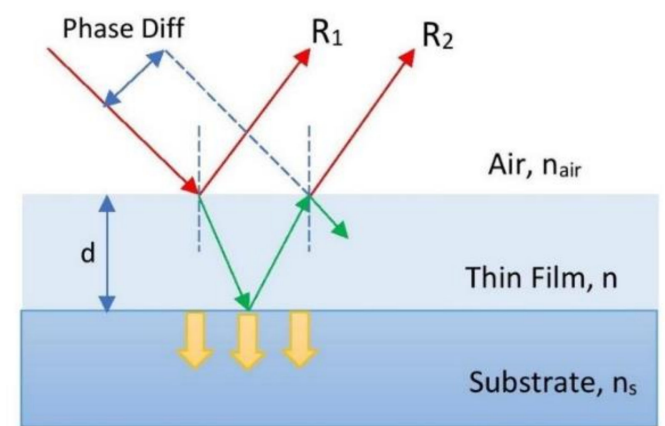

(b)

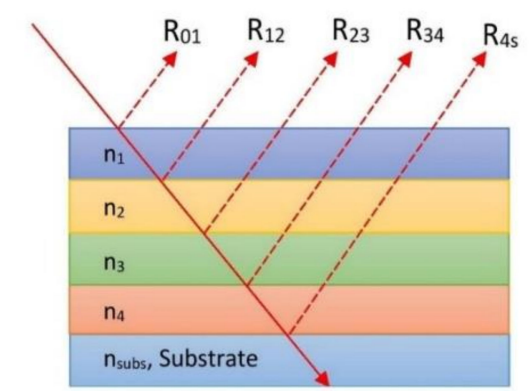

Figure 2. Schematic illustration of diffusion of light in (a) single layer film $\left(n_{\mathrm{S}}>n\right)$ and (b) multiple layer film.

The equation governing the reflectivity at normal incidence is as follows,

$$
R=\left|\frac{\left(n_{0} n_{\mathrm{s}}-n^{2}\right)}{\left(n_{0} n_{\mathrm{s}}+n^{2}\right)}\right|^{2}
$$

The single-layer coatings are useful only in the narrow wavelength range. The stacking of multiple layers of the thin film is proven to enhance the optical performance of the coating in a broad wavelength range with low reflectivity and also in a wide range of incident angles. The principle remains the same for the multi-layered antireflection coatings, but the mathematical model used in this case involves a vector analysis of the reflected individual rays. As represented in Figure $2 b$ the light reflected from the juncture of the two layers, $i$ and $j$ (assuming there are no losses) is provided in the equation as follows [36]:

$$
R_{i j}=\left|R_{i j}\right| \exp \left[-2\left(\delta_{i}+\delta_{j}\right)\right]
$$

where $\left|R_{m n}\right|=\left[\left(n_{i}-n_{j}\right) /\left(n_{i}+n_{j}\right)\right]$ and $\delta_{i}=2 \pi n_{i} d_{i} \cos \theta_{i} / \lambda\left(d_{i}, \theta_{i}\right.$ and $\lambda$ are the optical film thickness, the angle of refraction and wavelength of the light respectively.) Then, the total reflectivity $\left(R_{\text {sum }}\right)$ is obtained by integrating reflectance at the interface of each layer, which is expressed as:

$$
R_{\mathrm{sum}}=R_{01}+R_{12}+R_{23}+\ldots+R_{\mathrm{ns}}
$$

Thus, the $R_{\text {sum }}$ can be reduced by optimizing the index of refraction and optical film thickness appropriately to produce an antireflection effect [36]. 


\subsection{Methodology to Achieve Antireflection}

Antireflection can be provided to a substrate in many ways: (i) Stacking layers of different refractive index, (ii) Imparting porosity to the coating material, (iii) Texturing the surface, (iv) Gradient refractive index film. The stacking of films yields a moderate reduction in reflectance at a specific wavelength range, and as the number of films increases, the suppression of reflection loss can be obtained in a broad wavelength region. However, adhesion issues between the substrate and abutting film or within the layers of coatings due to thermal coefficient difference give rise to de-bonding problems causing instability.

Different fabrication methods can impart porosity, and the index of refraction is influenced by the fraction of the volume of the air and material. For instance, porous silicon is a sponge-like material having nano-voids within it. The index of refraction of porous silicon is reduced by increasing the porosity of the material and vice-versa. Porous ARCs are discussed further in Section 4.2.1. Textured surfaces having the space of the array lesser than the target wavelength and height being a fraction of the wavelength is suitable for AR application. Texturization can be established in both substrate and film surfaces. Another approach to lower the reflectance is to provide a gradually decreasing refractive index in the film. This gradual decrease in the refractive index of the film can be obtained by varying the density [43]. Such a configuration is known as a GRIN structure, and the degree of change in the index of refraction follows different profiles.

\subsection{Requirements for Perfect Antireflection Coatings}

Broadband anti-reflectivity: The ARCs must exhibit the AR properties in a reasonable wavelength range. In particular applications, it is desirable that ARCs should cover a broad wavelength region, including Ultra Violet (UV) region or near-infrared region.

Omnidirectional anti-reflectivity: Glasses and plastics possess a refractive index of about 1.5 and exhibit a $4 \%$ reflectance at normal incidence, but at grazing angles, it reaches up to $100 \%$. Similarly, antireflection coatings also exhibit such a phenomenon, and many coatings yield excellent AR properties mostly within the incident angles from $30^{\circ}$ to $60^{\circ}[44,45]$. Thus, Omni-directional anti-reflectivity is a critical characteristic that needs to be optimized.

High stability: ARCs should have a good bonding with the substrate surface and should be inert to the operating environment with excellent stability.

Multifunctionality: ARCs on the PV cell primarily helps to lower the reflection loss. Contrarily, the self-cleaning properties imparted to it owing to hydrophobicity can also help to solve the problem of dust accumulation. Thus, multifunctional ARC is a promising direction of research in the AR coating's area of expertise.

Polarization sensitivity: It is also required to analyze the effect of s- and p-polarized light on AR coatings. The s-polarization has an electric field oriented perpendicular to the incident plane, whereas the p-polarization has the incident plane parallel to the electric field. In applications such as antiglare coatings (AGCs), polarization plays a significant role.

Cost: Apart from having all the desired properties, the low cost of production makes it more appealing. Figure 3 represents the different criteria for perfect anti-reflection coatings. 


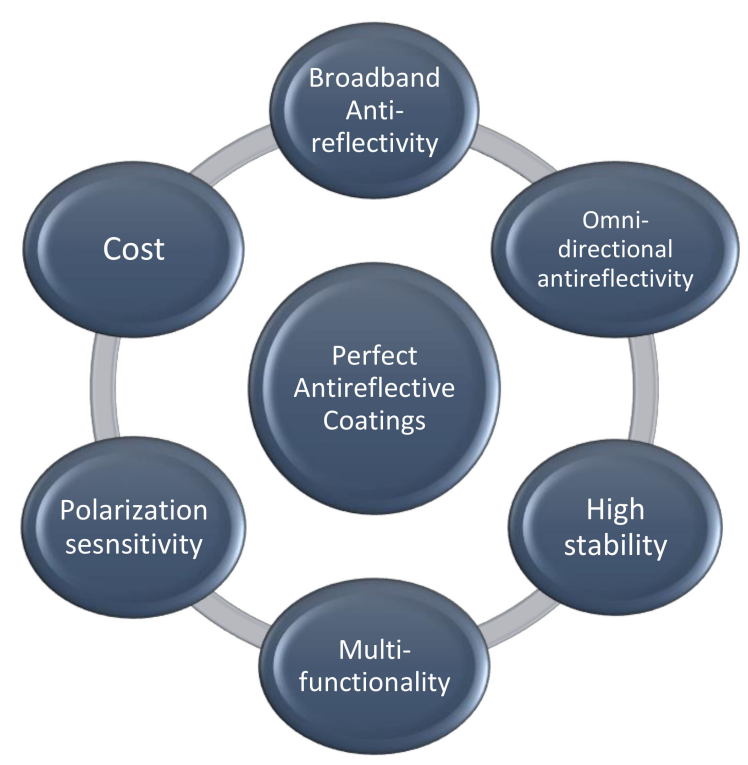

Figure 3. The various criterion for perfect antireflection coatings (ARCs).

\section{Antireflection Coating Structures and Surfaces}

\subsection{Antireflection Coating Structures}

\subsubsection{Single-Layer Coating (SLARC)}

It involves an application of a single layer film on the substrate to reduce the Fresnel reflection loss. SLARC is restricted to the required refractive index of the available materials. For instance, an antireflective coating on a substrate like glass and transparent plastic having an index of refractive of about 1.5 would require a film material with an index of refraction of 1.22 with quarter wavelength thickness. Unfortunately, materials with a lesser than or equal to the index of refraction of 1.22 are scarce, and usually, such a low refractive index is obtained by stacking of multiple layers. Only magnesium fluoride possesses such low refractive index $(n=1.38)$ and the utilization of which reduced the reflectance from just about $4 \%$ to almost $1.3 \%$ at a particular wavelength range as depicted in Figure 4 . Even then, achieving zero reflectance with a single layer is impractical. Generally, a SLARC is utilized for a moderate reduction in reflection to about $2.5 \%$ at normal incidence for a wide spectral range from $450-1100 \mathrm{~nm}[41]$.

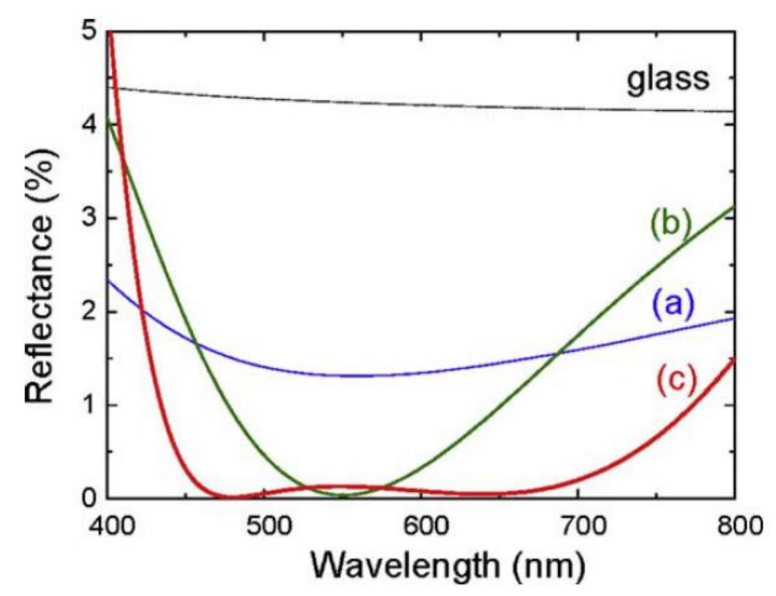

Figure 4. Comparison of reflectance of (a) SLARC (b) DLARC (c) Three-layer ARC. Reprinted with permission [42]; 2010, Elsevier. 


\subsubsection{Double Layer Coating (DLARC)}

DLARC employs two layers of the same or different thicknesses on the substrate to achieve antireflection property. The condition for obtaining zero reflectance using double-layer AR coatings of equal film thickness is $\frac{n_{1}}{n_{2}}=\sqrt{\frac{n_{0}}{n_{\mathrm{s}}}}$ where the $n_{1}$ and $n_{2}$ correspond to Refractive Index (RI) of two layers, $n_{\mathrm{S}}$ is the substrate refractive index, and $n_{0}$ is the RI of air which is unity [46]. In general, when a typical DLAR coating is used, the effective reflectance decreases significantly and approaches zero at the target wavelength and then increases gradually, thus exhibiting a V-shaped reflectance curve in the analyzed spectral range. Hence, DLAR coating is also described as V-coating. Double layer coatings are incredibly suitable for laser applications that demand minimal reflection at the emitted wavelength. Vicente et al. fabricated $\mathrm{SiO}_{2} / \mathrm{TiO}_{2}$ double-layer $\mathrm{ARC}$ by sol-gel technique on solar glass covers. The optimized film exhibited a transmittance value of 0.964 , and the maximum transmittance of 0.993 is achieved at $600 \mathrm{~nm}$ [47].

\subsubsection{Multi-Layer Coating}

A double-layer structure can effectively reduce the reflectance at the desired wavelength, but at either portion of the spectrum from the target wavelength, the reflectivity sometimes increases even higher than a single layer ARCs. Thus, multiple layers are employed for reducing the effective reflectance at a broad wavelength range. Figure 4 shows the comparison of reflection loss of SLARC, DLARC, and multiple-layer ARCs. Thus, multiple layers of AR coating are used, especially for attaining broadband anti-reflection. The overall reflectivity and larger bandwidth are often contrasting to one another and are the main challenge facing us. Bouhafs et al. designed and deposited various AR coatings such as $\mathrm{Ta}_{2} \mathrm{O}_{5}$, $\mathrm{ZnS}$ single layer ARCs, $\mathrm{MgF}_{2} / \mathrm{ZnS}$ double-layer, and $\mathrm{MgF}_{2} / \mathrm{Al}_{2} \mathrm{O}_{3} / \mathrm{ZnS}$ triple-layer ARCs on Si substrate using electron beam and thermal evaporation techniques [48]. The ZnS coating is observed to be more transparent than $\mathrm{Ta}_{2} \mathrm{O}_{5}$ in the short wavelength region. The reflectance for $\mathrm{MgF}_{2} / \mathrm{ZnS}$ DLARC is $9.1 \%$ and $0.58 \%$ at $500 \mathrm{~nm}$ and $1000 \mathrm{~nm}$, whereas for $\mathrm{MgF}_{2} / \mathrm{Al}_{2} \mathrm{O}_{3} / \mathrm{ZnS}$ triple-layer ARCs it is $5.8 \%$ and $0.88 \%$ at $500 \mathrm{~nm}$ and $1000 \mathrm{~nm}$, respectively. This shows the broader low reflectance in the multi-layer coating.

\subsubsection{Gradient Refractive Index (GRIN) Coating}

The GRIN coating can be assessed as the next generation of single-layer AR coatings which eliminates the limitations such as AR effectiveness at only a narrow wavelength range and normal incidence. A sequence of layers having a refractive index changing gradually at each step constitutes gradient refractive index coating. Alternatively, an inhomogeneous film of monotonically varying refractive index is preferred, and also it serves as a broadband anti-reflective coating. Different profiles of gradient RI layers have been proposed for omnidirectional and broadband AR coatings, which include linear, parabolic, cubic, gaussian, quintic, exponential, exponential-sine, and Klopfenstein [42,49-55]. Linear index profiles can be achieved easily on silicon or quartz substrates. A study reported $\mathrm{SiNx}$ films having a linear index profile as an antireflection coating with low reflectance in the near infra-red and visible regions for a wide incidence angle [56]. The typical expressions for GRIN coatings with linear, cubic, and quintic profiles $[42,51]$ are as follows:

Linear index profile:

$$
n=n_{0}+\left(n_{\mathrm{s}}-n_{0}\right) t, 0 \leq t \leq 1
$$

Cubic index profile:

$$
n=n_{0}+\left(n_{\mathrm{s}}-n_{0}\right)\left(3 t^{2}-2 t^{3}\right)
$$

Quintic index profile

$$
n=n_{0}+\left(n_{\mathrm{s}}-n_{0}\right) t\left(10 t^{3}-15 t^{4}+6 t^{5}\right)
$$

where $n_{0}$ and $n_{\mathrm{s}}$ are the refractive indexes of incident and substrate media, $t$ is the optical film thickness of gradient RI, respectively. Figure 5a shows the variation of RI with thickness for linear, cubic, 
and quantic-gradient index profiles. The calculated reflectance of linear, cubic, and quantic GRIN profiles are shown in Figure $5 b$, and Figure $5 c$ represents the variation of reflectance to the different incident angles. $\mathrm{Xi}$ et al. [57] reported a GRIN ARC with a linear, cubic, and quintic index profile and found that a quintic profile is the most exceptionally performing AR profile.
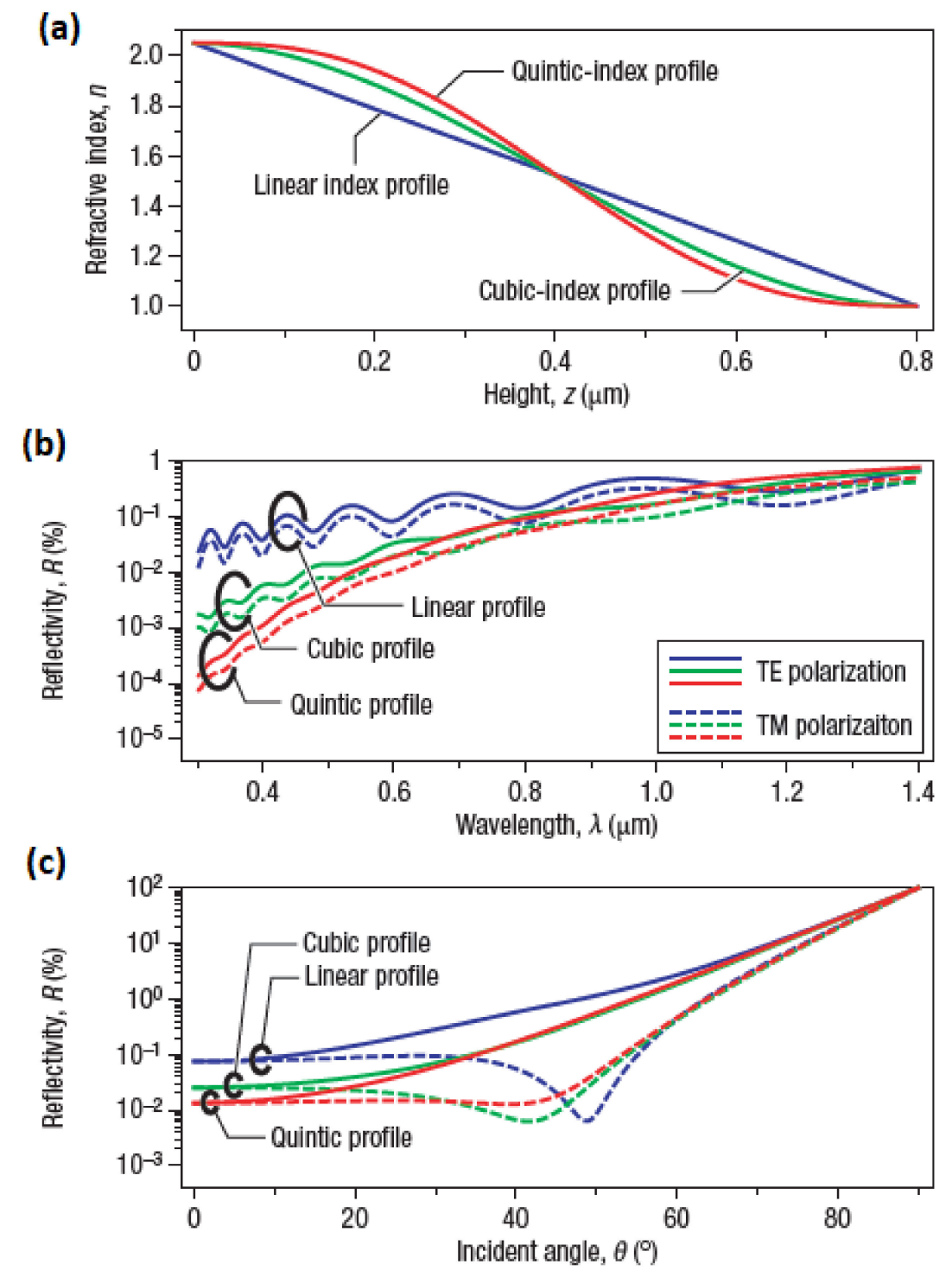

Figure 5. Comparison of various index profiles for gradient RI coating. (a) Variation of refractive index of linear, cubic and quantic -index profiles as a function of thickness (b) Variation of reflectance with respect to wavelength for linear, cubic and quantic-index profiles at normal incidence. (c) Variation of reflectance with respect to incident angle for linear, cubic and quantic-index profiles at $632.8 \mathrm{~nm}$ wavelength. Reprinted with permission [42]; 2010, Elsevier.

When analyzing the limitations of GRIN structures, the index matching of the film to the refractive index (RI) of air and substrate is a tedious job. Moreover, it is practically impossible to achieve the RI of the film at the film-air interface as unity. Gradually varying RI can be obtained by reducing the packing density of the film. However, even then, perfect index matching is not possible, and this would lead to some optical losses. Further, reducing the packing density along the film thickness would trade-off mechanical robustness and durability. 


\subsection{Antireflection Coating Surfaces}

Antireflection characteristics can also be obtained in light of the material's topography. The surface of substrate material mixed with air on a subwavelength scale [58] would exhibit antireflection property such as porous or textured surfaces. Various physical or chemical processes can fabricate these textured and porous surfaces. Specific sub-wavelength structures (SWS) were inspired by natural structures, like moth-eye or cicada's wings [59,60]. Researches on these surfaces for antireflection coatings are reported to be active and this remains a promising area of research. In this section, the different surfaces imparted in ARC are discussed.

\subsubsection{Porous Layers}

Numerous researches have been undertaken in this area, especially in porous silicon, and the application of nano-porous film as an antireflection coating had been established, followed by the evolution of etching techniques [61,62]. The essential requirement is that the size of the pore should be much smaller when compared to the wavelength of the light, and the Refractive index (RI) of the nano-porous film is obtained by averaging over the whole surface. Porous single-layer and GRIN films have been fortunately fabricated by the chemical etching process on the substrate and are refined by subsequent heat treatment processes. The film thickness and the density of the porous material is the vital factor that imparts the gradient RI and influences the overall RI of the film. This factor can be supervised by altering the fabrication parameters. Also, the porous film would provide a minimal reflectance feature about a wide-angle of incidence [63,64]. In a study by Steiner's group, a high-performance broadband antireflection coating is obtained by using nanophase-separated polymer films and by precisely varying the volume fraction, the RI ranging from 1.2 to 1.05 is obtained. The prepared film exhibited an excellent AR property with an average transmittance of $99.7 \%$ in the wavelength span of visible light [65].

\subsubsection{Biomimetic Photonic Nanostructures}

The SWS in a periodic arrangement acting as an AR surface was first discovered in the night-flying moth's eye by Bernhard in 1967 [59]. Researchers have successfully replicated the moth-eye structures on a glass substrate with lithographic techniques [60]. The AR structure of the moth-eye consists of an outer surface having sub-micron height and spaced nipple arrays. Therefore, the index of refraction varies progressively between air and substrate, actively suppressing the reflection at the juncture of two media. The reflectance of such structure depends on the spacing between the arrays, the effective height of the nanostructures, and the wavelength. In an ideal case, AR for broad bandwidth can be obtained through regulating the space as finer as possible and by increasing the height. For replicating the nipple structures, three models were proposed having conical, paraboloidal, and Gaussian-bell shapes $[10,66]$, and it has been reported that parabolic shaped nipple exhibited excellent AR performance at normal incidence. Also, a significant decrease of reflectance takes place for nipples having greater width where they overlap at the base and is progressively reduced when the height is increased. Moreover, SWS is reported to have excellent compatibility with the PV substrate materials. Siddique et al. analyzed the role of random nanostructures of glass wing butterfly for omnidirectional AR properties, and it is observed that these wing structures possess irregularly distributed pillar arrays of random heights [11]. The transparent wing structures exhibited remarkably low haze and excellent AR properties, even for large viewing angles. A detailed discussion on biomimetic structure AR coating is produced in the referred review article [36,38].

\subsubsection{Textured Surfaces}

Surfaces having a texturization period lesser than the target wavelength and height being a fraction of the wavelength is suitable for AR application [67-71]. Theoretically, if the wavelength of the light is much larger than the spacing between the structures, then the textured surface can be 
treated as layers with gradually changing RI (Figure $6 c, d$ ), and the optical properties can be predicted by utilization of effective medium approximation. If the wavelength of the light is shorter than the period between textured structures, the rays would undergo multiple reflections and get trapped inside the crevices (Figure $6 \mathrm{a}, \mathrm{b}$ ). In this case, the optical properties are defined by geometry only, and the numerical modeling is carried out with the help of a ray-tracing method [72]. By selecting proper material and choosing an appropriate depth of texturing, efficient spectral absorber coating for solar thermal conversion and photovoltaic applications can be designed. Textured crystalline silicon can reduce the surface reflectance to $\sim 10 \%$ [73] while it can be reduced to $\sim 1 \%$ in textured amorphous silicon $[68,69]$. These textured structures comprise of pillar arrays with diameters and the air gap between them lower than the incident light wavelength and also with the height equal to or higher than that of the wavelength of the light.

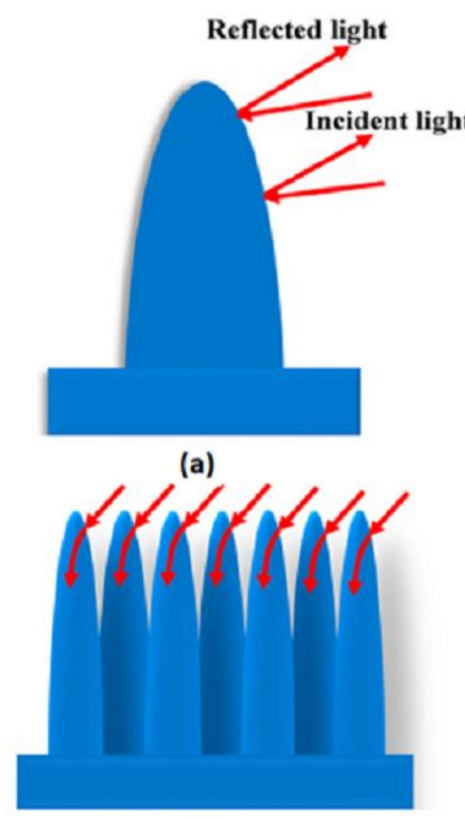

(c)
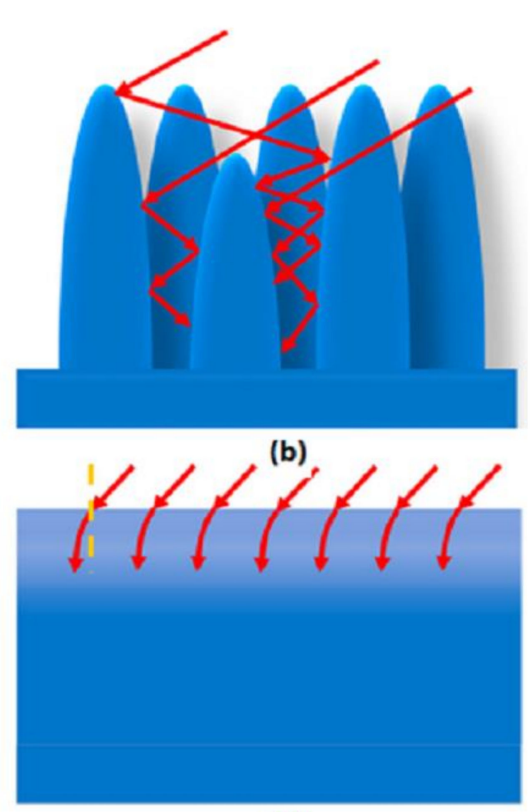

(d)

Figure 6. (a) Light interaction with macrostructure. (b) Multiple internal reflections resulted due to microstructure arrays. (c) Light interaction with nanostructure array. (d) Light interaction with GRIN structure resulting in bending of light rays. Reprinted with permission [36]; 2019, Elsevier.

\section{Fabrication Techniques for Antireflection Coatings}

The fabrication methods are the crucial steps in which the desired properties can be modified by varying the fabrication parameters. For a particular application, after selecting the material for an AR coating, choosing the preparation method is vital. Fabrication of accurate structures, smoother control, adaptivity, and cost-effectiveness are some considerable outcomes that a methodology should possess. In general, the fabrication techniques are classified as a bottom-up approach and a top-down approach under conventional techniques. Some unconventional techniques of fabrication are often used for preparing antireflection coatings. This section discusses both the conventional and non-conventional fabrication approaches with appropriate examples briefly. Figure 7 shows the classification of fabrication techniques forARCs. 


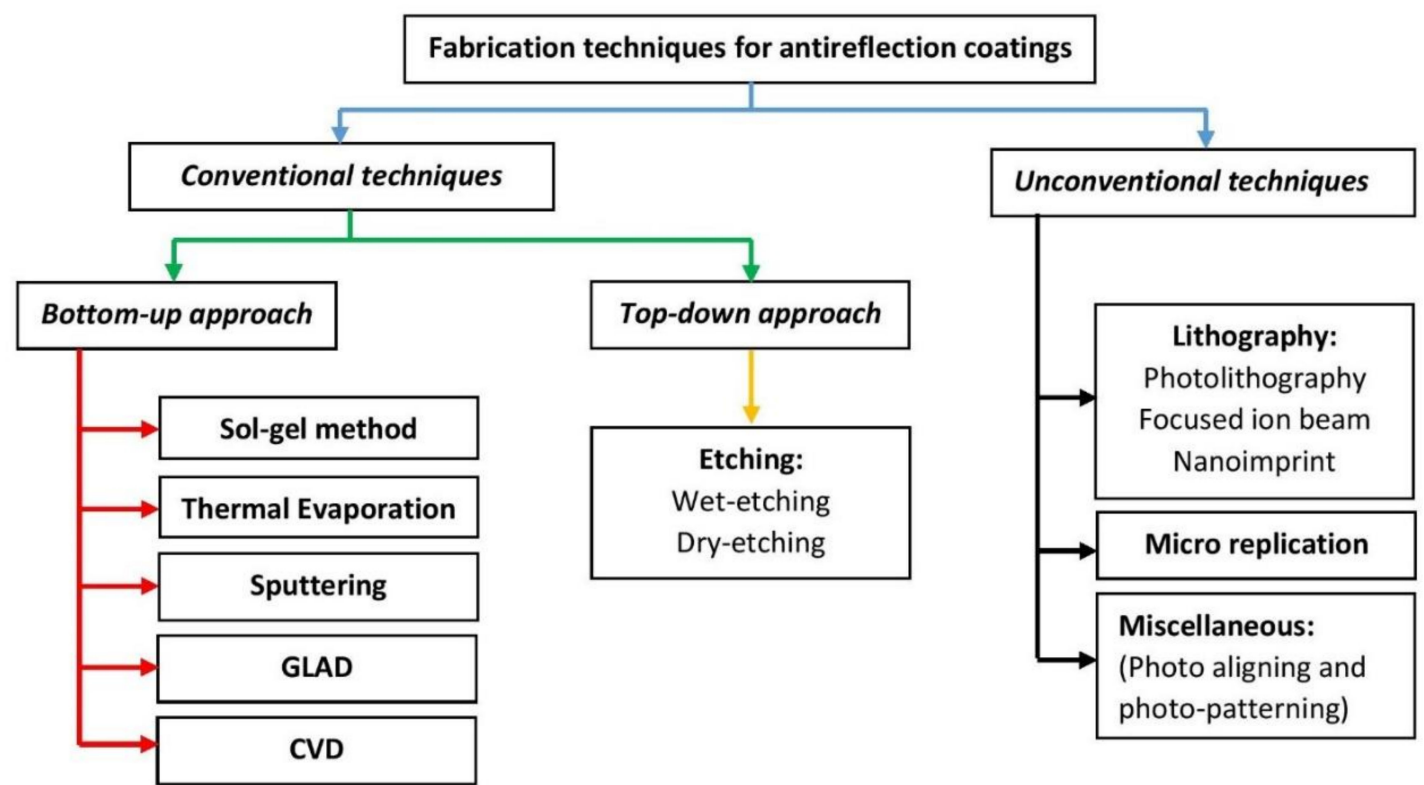

Figure 7. Classification of commonly used fabrication techniques for ARCs.

\subsection{Conventional Techniques: Bottom-Up Approach}

\subsubsection{Sol-Gel Method}

The sol-gel method is the most common approach to produce metal oxide nanoparticles and mixed oxide composites and is industrially used to produce AR coatings. The steps involved in the synthesis of the metal oxide include hydrolysis, condensation, and drying process. The process uses inorganic salts as precursor materials and is mixed in an organic solvent to undergo hydrolysis to form a solution of metal hydroxide, and a three-dimensional gel is formed as a result of subsequent condensation. Then, the obtained gel is allowed to dry in the drying process, which yields Xerogel or Aerogel. The reaction pathway is shown in Figure 8. Depending on the solvent's nature, the sol-gel method is classified into aqueous sol-gel and non-aqueous sol-gel method [74].

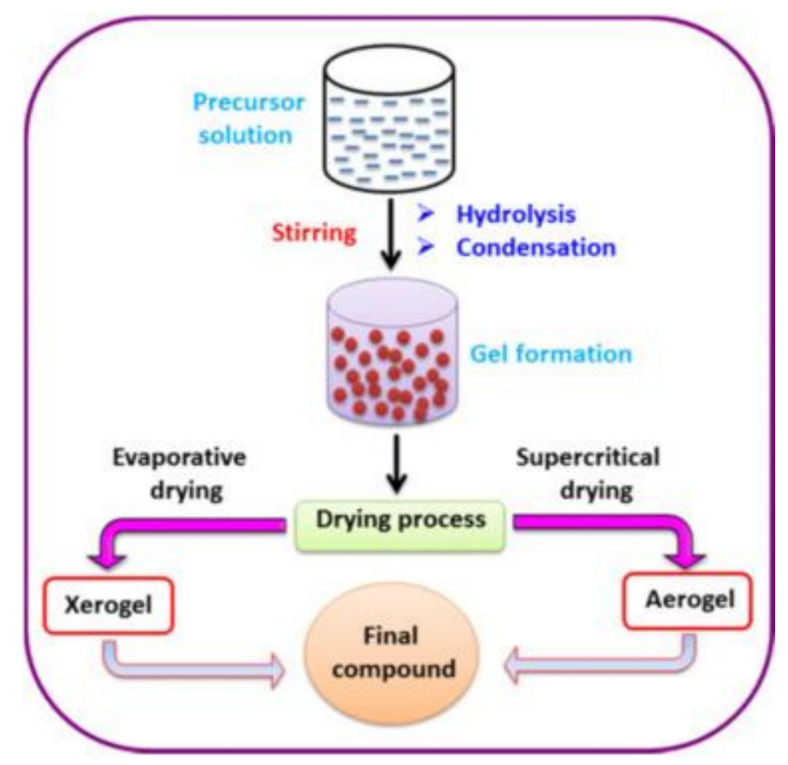

Figure 8. The reaction pathway involved in sol-gel synthesis of metal oxide nanostructures. Reprinted with permission [74]; 2017, Elsevier. 
The aqueous sol-gel method uses a water solvent as a reactive medium, and the water solvent provides oxygen required for the formation of the corresponding metal oxide. Usually, employed metal precursors for this method are metal alkoxides, metal acetates, chlorides, sulfates, and nitrates, out of which metal alkoxides are commonly utilized metal precursors owing to their increased reaction towards the water. In most instances, the process of hydrolysis, condensation, and drying takes place concurrently due to which controlling the morphology and reproducibility of the material becomes difficult, which is significant for fabricating nano-oxide layers. Hence, it is believed that this method is more suitable for bulk metal oxide synthesis than nano-oxide synthesis. The non-aqueous sol-gel method uses organic solvent as the reactive medium, and organic solvents supply the oxygen required for the formation of the metal oxide. This method is superior to the aqueous sol-gel method because of its versatility for tuning vital components such as morphological structure, surface properties, and particle size through the influence of the organic solvent. Thus, the non-aqueous sol-gel method is mainly employed for the preparation of nano-oxides.

The different coating methods widely adopted to coat sol-gel are as follows and is depicted in Figure 9.

Dip coating: Here, the substrate is dipped in the prepared solution and is retracted at a regulated feed rate and hence the name dip-coating. Depending on this feed rate, the morphology and particle size are affected, which in turn affects the antireflective property of the coating. The sequential steps involved in this process are immersion, start-up, deposition, evaporation, and drainage.

Spin coating: In this methodology, the uniform film is formed with the assist of centripetal force due to spinning action. It is a group-production process in which thin coatings can be deposited on a flat substrate or the substrate curved at the end. A viscous film is deposited and subjected to spin at high rpm (of about $3000 \mathrm{rpm}$ ) and, therefore, forcing the film to spread over the substrate. Here, the rpm is a crucial factor to shape the structure.

Meniscus coating: In this methodology, the material is coated on the substrate surface through a porous device that always maintains a meniscus between the substrate and the device. It can result in micron level thickness, and are commonly employed in display panels, optical devices, and an enhanced technique based on this method is used in the paint industry.

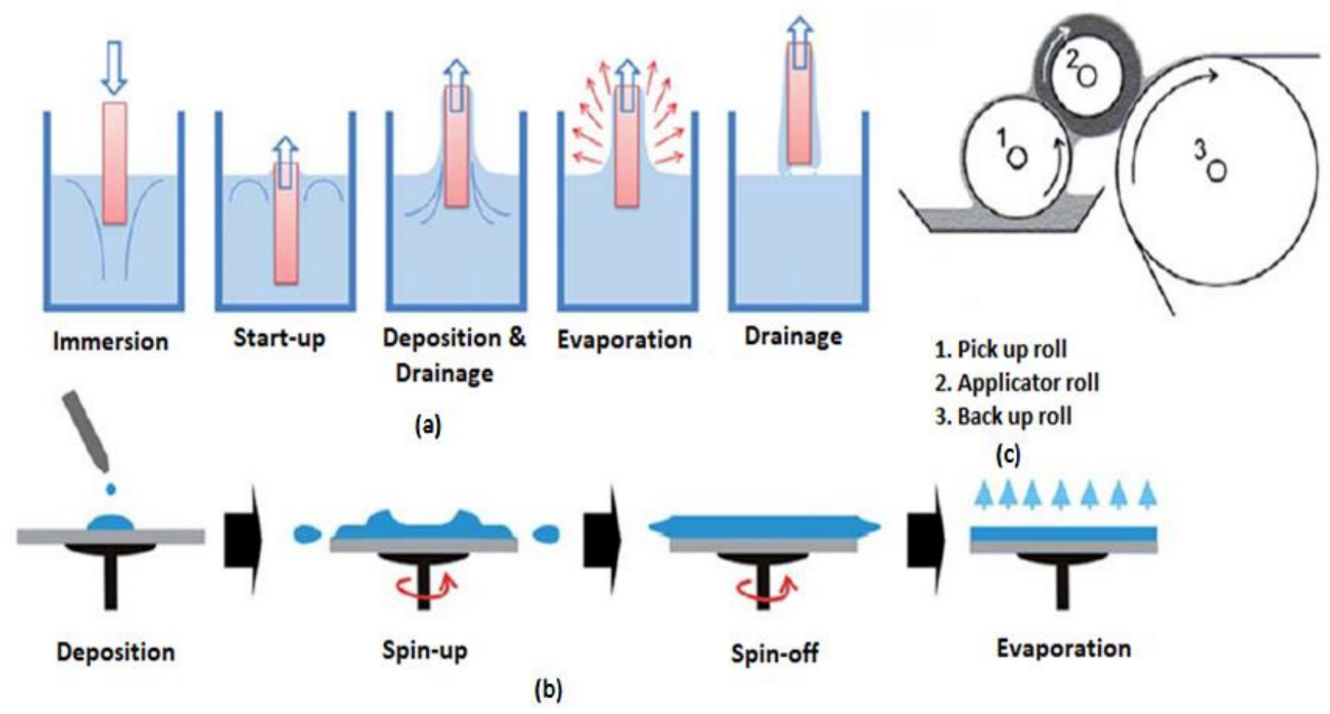

Figure 9. Steps involved in various coating techniques (a) Dip-coating (b) Spin-coating (c) Meniscus-coating. Reprinted with permission [39]; 2016, Elsevier.

\subsubsection{Thermal Evaporation}

The thermal evaporation technique involves the vaporization of coating material in a vacuum chamber maintained below $10^{-4} \mathrm{~Pa}$ and the subsequent condensation of evaporated atoms on the 
substrate surface. It is also regarded as vacuum deposition since the process is carried out in vacuum to avoid the oxidation issues. The evaporation of the source material is accomplished either by resistive heating or electron beam heating [75]. Resistive heating is most commonly employed for depositing thin films, and the coating material is generally vaporized in a resistively heated filament or boat crucible constructed using refractory metals such as Molybdenum, Tungsten, and Tantalum with or without ceramic layer. Electron beam heating is performed in an ultrahigh vacuum for those materials which cannot be resistively heated. The typical design of a thermal evaporation system is shown in Figure 10. The evaporation process can be assisted by microwave, plasma, or electron resonance to have control over the deposition rate or on the properties of the vaporized materials [76]. Many AR coatings are developed using this technique. For example, Zaier et al. prepared $\mathrm{ZnO}$ thin films using thermal evaporation technique and refined the structural, electrical, and optical properties by subsequent annealing at different temperature ranges. Such coatings exhibited transmission spectra higher than $90 \%$ within the visible wavelength range [77].
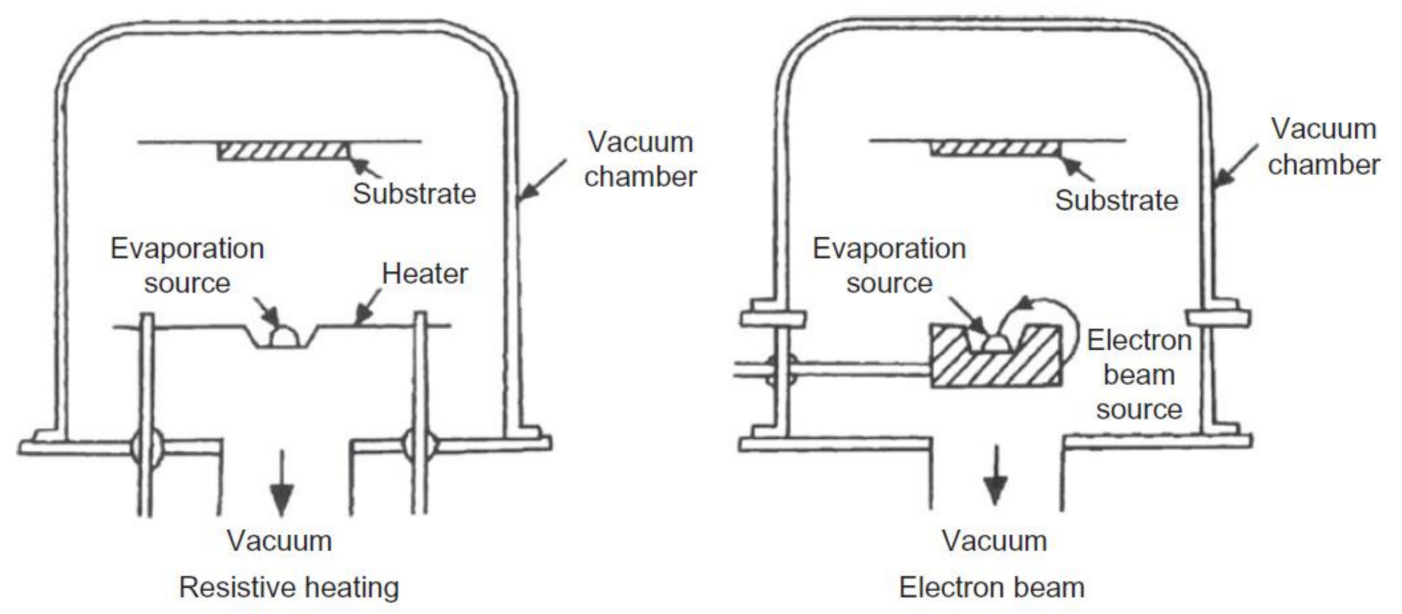

Figure 10. Typical thermal evaporation system representing resistive heating and electron beam heating. Reprinted with permission [75]; 2012, Elsevier.

\subsubsection{Sputtering}

The sputtering deposition technique ranges from a simple Direct Current (DC) diode sputtering system to sophisticated reactive magnetron sputtering. In this method, the coating material is extracted from the cathode (source) by bombarding with accelerated positive ions of inert gas (Argon) and then transmitting the energy and momentum to the substrate (target). There exist various sputtering deposition systems, such as ion-beam sputtering, reactive sputtering, and magnetron sputtering, that are commonly used for depositing thin-films of ARCs. For instance, Zhaoyong Wang et al. fabricated double-layer AR coating using single material $\mathrm{TiO}_{2}$ by using a magnetron sputtering technique. The layer with low RI is obtained from a direct reactive magnetron sputtering, while the layer with higher RI is prepared from energy filtrating magnetron sputtering [78]. The coating exhibited excellent photocatalytic performance and the antireflective property, with average and maximum transmittance of $88.4 \%$ and $98.9 \%$ in the visible spectrum.

\subsubsection{Glancing Angle Deposition (GLAD)}

The GLAD technique is an improvized version of physical vapor deposition that involves the condensation of vaporized material on to the substrate. In this method, the substrate is either stationary or rotated at a constant rate, and the vapor flux is incident at an angle to the substrate (Figure 11ii). By doing so, thin films can be grown at gradually increasing porosity owing to the atomic-scale shadowing (Self-shadowing), as shown in Figure 11iii [79]. If the substrate is held at an oblique angle without rotating, the resultant nanostructure will be tilted towards the source (tilted nanostructure, 
Figure 11ia. When the substrate is rotated to $180^{\circ}$ at fixed intervals, then a zig-zag pattern is formed (chevron nanostructure, Figure 11ib. A helical nanostructure is formed by rotating the substrates (helical column nanostructure, Figure 11ic. When the substrate rotation rate is increased further, the pitch of the helical structure approaches the diameter of the column, and the helical structure degenerates into a vertical column structure (Figure 11id). The advantage of this technique is that the morphology and the porosity of the resultant nanostructure can be accurately controlled by the rotational speed of the substrate and vapor flux incidence angle. The larger the oblique angle, the higher the film's porosity and vice-versa. GLAD technology has advanced to fabricate thin films with slanted, helix, chevron, vertical, and other morphology-based nanostructures. The microstructure and nanostructure of the GLAD deposited films possess an increased surface area. Some applications require surface area enhancement, like electrodes employed in dye-sensitized solar cells (DSSC). Kiema et al. fabricated a DSSC in which the $\mathrm{TiO}_{2}$ electrode is deposited using the GLAD technique, and the device exhibited a PCE of $4.1 \%$ [80].

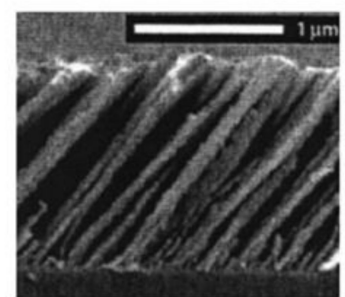

(a)

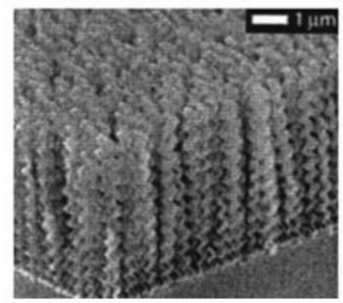

(c)

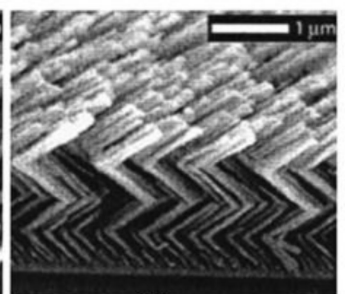

(b)

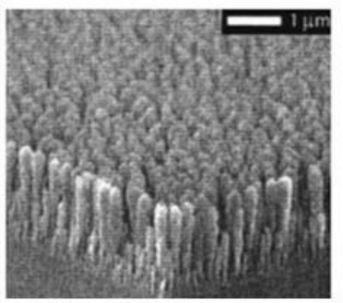

(d)

(i)

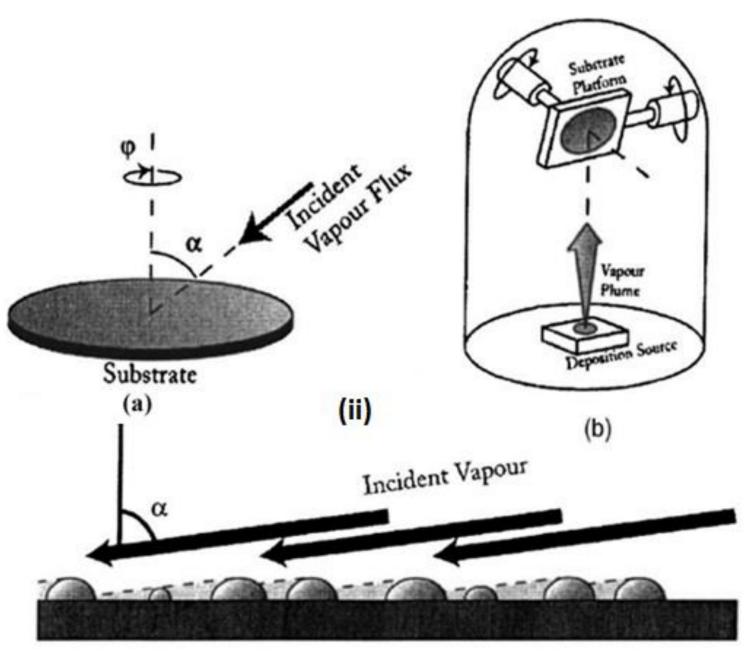

(iii)

Figure 11. (i) GLAD deposited microstructures (a) tilted structures, (b) Chevron or zig-zag structures, (c) helical structures, (d) vertical columns. (ii) (a) The angle of deposition $\alpha$ and the rotation angle of the substrate $\Phi$ to the deposition plane. (b) Typical GLAD apparatus implemented in the PVD system. (iii) Nuclei distributed across the surface leads to ballistic shadowing of the surrounding regions. Reprinted with permission [79]; 2007, AIP Publishing.

By varying the deposition angle, a gradient refractive index can be produced in the films. Kennedy and Brett used GLAD to deposit $\mathrm{SiO}_{2}$ films onto the glass substrates, and the resulted graded-index films effectively suppressed the Fresnel reflection loss [81]. The above-mentioned film exhibited a peak transmittance higher than $99.9 \%$ at normal incidence and more than $99.0 \%$ transmittance between $0^{\circ}$ and $30^{\circ}$ range of incident angles within the wavelength range of 450-1000 nm.

\subsubsection{Chemical Vapor Deposition (CVD)}

Chemical vapor deposition is the technique that involves the deposition of materials in the vapor phase onto the heated substrate surface by the decomposition of chemicals. The materials with different physical, chemical, and tribological properties can be grown on the substrate material by varying the operating parameters such as substrate temperature, gas pressure, substrate material, and the composition of reaction gas mixture. The key feature of the CVD method is that a uniform thickness can be obtained with low porosity even with substrates of complex shapes.

Plasma enhanced CVD (PECVD) is a widely utilized fabrication method for silicon nitride ARCs on c-Si solar cells and is industrially used method. On the other hand, radio frequency PECVD 
(RF-PECVD) remains effective in depositing uniform coatings on the substrates of various shapes and sizes [82]. RF-PECVD has employed in coating diamond-like carbon (DLC) films on Si substrate for the application of Infrared windows and antireflection coatings for solar cells. Remache et al. fabricated a dual-layer of porous silicon and silicon oxide by PECVD technique [83]. The fabricated layer shows improved stability, and passivation properties and with the thickness of $105 \mathrm{~nm}$ of SiOx film, the effective reflectance is reduced to $3.8 \%$. Another CVD method commonly used for fabricating AR coatings is atmospheric pressure chemical vapor deposition (APCVD). Neuman prepared a GRIN layer composed of $\mathrm{SiO}_{2}$ and $\mathrm{TiO}_{2}$ via APCVD, and this layer showed a reflectance of only 0.5\% [84].

\subsection{Conventional Techniques-Top-Down Approach}

\section{Etching}

The etching is a process of removing the material simultaneously on the whole area of the substrate by the action of chemical reactions, which causes a selective dissolution or an ablation on the substrate to obtain a specific pattern. Etching belongs to the family of subtractive patterning and can be a mask assisted process by selectively protecting the material or mask-less process. Depending on the nature of the etching, it can be regarded as isotropic and anisotropic etching. The former gives a uniform material removal rate of the exposed surface while in anisotropic etching, the materials are removed quickly in random directions leading to a non-uniform removal rate. Wet etching and dry etching prevail to be the major etching approach that is generally used for antireflection coating synthesis. In wet etching, the whole substrate is submerged in the etchant (chemical solution), and the material that is not to be removed should be either inert to the solution or must be protected by using a mask (mask-assisted). The factors that influence the rate of etching are the concentration of the etchant, the rate of waste product removal, and the temperature [85]. In a study, silicon-based antireflective SWS is fabricated by wet etching techniques in the presence of nano-sized gold $(\mathrm{Au})$ as a catalyst [86]. The selection of metal catalysts and their shape actively governs the etching process. Another technique that makes the gold particles get attached to the substrate surface is by preheating the substrate and soaking them in an aqueous solution of HF and water, which is then etched using gold catalysts. A black appearance is obtained by the end of $15 \mathrm{~min}$, and this surface demonstrated a reflectance of less than $5 \%$ in the $300-800 \mathrm{~nm}$ wavelength range.

Dry etching involves the removal of material by the bombardment of ions on the exposed surface. The reactive ion etching (RIE) is commonly regarded as dry etching, which involves a chemical reaction between the substrate material and the gaseous etchant. This method can yield more delicate features on the substrate surface as the gas can enter small spaces than liquids and solids comparatively. In certain studies, chlorine trifluoride $\left(\mathrm{ClF}_{3}\right)$ gas was employed as a dry etchant to produce substrates with honeycomb textured nanostructures [87-89]. It is also seen that $\mathrm{ClF}_{3}$ gas is capable of etching the Si surface at near room temperature without plasma, and also, it does not affect the positive-type photoresist mask material.

\subsection{Unconventional Fabrication Techniques}

\subsubsection{Lithography}

Lithography is a process of pattern transfer from a mold having nanoscale features to the substrate surface. Generally, for fabricating antireflection coatings, techniques such as photolithography, focused ion-beam lithography (FIBL), and nanoimprint lithography (NIL) are often utilized apart from the conventional techniques. Photolithography involves an optical means of producing a pattern on the substrate. In this technique, initially, a photoresist film is placed on the substrate and masking of the selected region is done. After masking, it is exposed to electromagnetic radiations [90], and due to photo-induced reaction, the solubility of the photoresist layer exposed to the radiation changes. Then, the developer solution dissolves the photoresist layer exposed to radiation, and etching is carried out 
to remove the film below it. Finally, the remaining photoresist layers are stripped off. Zhou et al. [91] used photolithography to develop the superhydrophobic micropillar arrays, and the illustration of the various steps involved in the photolithography method is shown in Figure 12.

In ion and electron-beam lithography, a focused beam of ions and electrons respectively are employed instead of electromagnetic waves as in photolithography. The focused ion beam lithography possesses less backscattering since ions are much heavier, and a high-resolution patterning can be obtained than UV or electron beam.

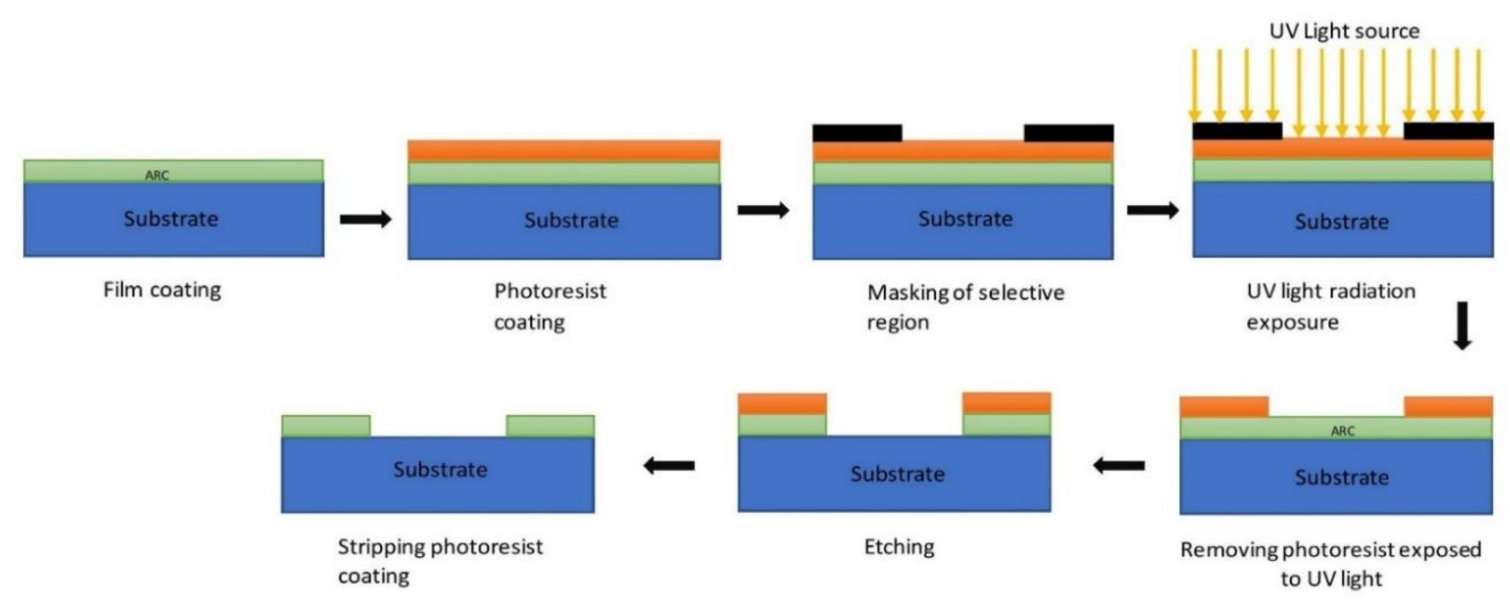

Figure 12. Schematic illustration of steps involved in photolithography.

Nanoimprint lithography (NIL) is also referred to as mold lithography as it does not use light or charged particles; instead, it utilizes the mold to fabricate the structures [92]. It uses a high precision mold made of hard materials. The required topographical nano features are first created on the mold using appropriate advanced techniques. Then, the mold is pressed against the coated substrate to impart the pattern on the substrate surface. After the removal of the mold, the substrate is subjected to a standard RIE to clean the compressed resist. The process of NIL is illustrated in Figure 13i [93]. Kim et al. used a thermal nanoimprinting method to prepare a PMMA film having a nanopillar structure with a spacing of $300 \mathrm{~nm}$ between them. The silicon master imprint used is obtained by the utilization of laser lithography and dry etching techniques. The nanoimprinted polymer film exhibited multifunctional behaviors such as antimicrobial, antireflective, and antiadhesion properties. The reflectance of the film is lesser than $0.5 \%$ in the $400-800 \mathrm{~nm}$ wavelength range [5]. 


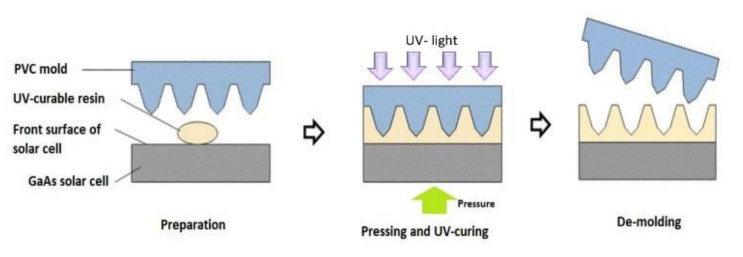

(i)

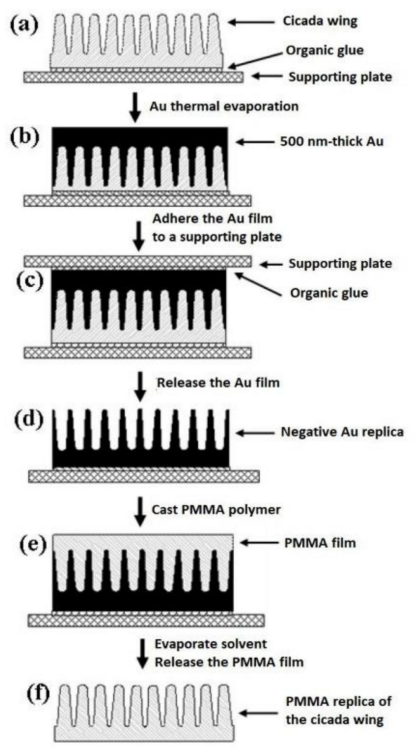

(ii)

Figure 13. (i) Illustration of various steps in the preparation of moth's eye pattern using nano-imprint lithography methodology. Reprinted with permission from Ref. [93]; Copyright 2011, Elsevier (ii) Stepwise illustration of bio-replication method with cicada wing as a template. (a) Cicada wing structure. (b) Depositing Au on the Cicada wing structure through thermal evaporation. (c) Adhering the $\mathrm{Au}$ film to the supporting plate. (d) Releasing the Au plate to obtain the Au mold. (e,f) Replicating the cicada wing structure on the PMMA film through prepared Au mold. Reprinted with permission [42]; 2010, Elsevier.

\subsubsection{Micro Replication Technique}

Nano-fabrication techniques without using lithography have been actively pursued owing to their disadvantages, such as high-cost fabrication techniques, inefficiency in generating 3D structures. New microreplication methods such as soft lithography, micro-cutting process, and micro-stereo lithography have been developed. Out of which, soft lithography is extensively carried out in the effective fabrication of nanostructures in PV application. Soft lithography is also a pattering method which uses an elastomeric stamp to deposit ink on the substrate. The main advantages of this fabrication methodology are more straightforward setup, relatively low cost, and high resolution with high precision. One major drawback of this method of soft lithography is the dependency on lithography methods to create a master pattern. The polydimethylsiloxane (PDMS) polymer is typically used to fabricate the mold due to its high optical transparency, elasticity, hydrophobicity, biocompatibility, and gaseous permeability. Two modes of soft lithography exist, namely micro-contact printing and microfluidics. In microcontact printing, the ink is transferred by bringing the stamp in contact with the substrates. In microfluidic patterning, the ink flows through the channels created by elastomeric stamp across the substate due to capillary forces. Lim et al. fabricated an antireflection film made of PDMS with an inverse tapered nanoholes structure produced by a soft lithography technique [94]. The template is made of Si molds having conical nanopillar structures. The nanohole structured PDMS film with a thickness of $320 \mathrm{~nm}$ is deposited on the FTO glass substrate, and it exhibited a minimum reflectivity of about $\sim 7.1 \%$ at normal incidence in 350 to $800 \mathrm{~nm}$ span of wavelength. Also, in some cases, natural structures are directly employed as a bio-template for the replication of the same, and one such case is demonstrated in Figure 13ii, where the cicada wings are used as a template and is replicated on Au template which is transferred to PMMA film. A comparison of the discussed fabrication techniques is shown in Table 2. 
Table 2. Comparison of various fabrication technologies commonly used for antireflection coatings.

\begin{tabular}{|c|c|c|c|c|c|c|c|c|c|}
\hline $\begin{array}{l}\text { Fabrication } \\
\text { Techniques }\end{array}$ & $\begin{array}{l}\text { Controlling } \\
\text { Parameters }\end{array}$ & $\begin{array}{l}\text { Type of Coatings } \\
\text { Commonly } \\
\text { Fabricated }\end{array}$ & Facileness & $\begin{array}{l}\text { Uniformity of the } \\
\text { Deposited Coating }\end{array}$ & Film Quality & $\begin{array}{c}\text { Deposition } \\
\text { Rate or Rate } \\
\text { of Fabrication }\end{array}$ & Cost & Advantages & Disadvantages \\
\hline Sol-gel & $\begin{array}{l}\text { Type of precursors, the } \\
\text { concentration of } \\
\text { precursors and } \\
\text { additives, solvent } \\
\text { nature, pH of the } \\
\text { solution, pre- and post- } \\
\text { heat treatment }\end{array}$ & $\begin{array}{l}\text { Metal oxide and } \\
\text { dielectric (silica) } \\
\text { thin films, } \\
\text { nanoporous films }\end{array}$ & Yes & $\begin{array}{l}\text { Depends on the } \\
\text { coating used and } \\
\text { the controlling } \\
\text { parameters. Spin } \\
\text { coating yields } \\
\text { higher uniformity }\end{array}$ & $\begin{array}{l}\text { High } \\
\text { homogenous } \\
\text { films can be } \\
\text { obtained }\end{array}$ & $\begin{array}{l}\text { Very fast } \\
\text { deposition }\end{array}$ & Low-cost & $\begin{array}{l}\text { Simple, fast, low } \\
\text { temperature, and } \\
\text { inexpensive } \\
\text { technique }\end{array}$ & $\begin{array}{l}\text { Precise control in } \\
\text { tuning the } \\
\text { morphology and } \\
\text { reproducibility is } \\
\text { difficult }\end{array}$ \\
\hline $\begin{array}{l}\text { Thermal } \\
\text { Evaporation }\end{array}$ & $\begin{array}{l}\text { Pressure and substrate } \\
\text { heat are the prime } \\
\text { parameters. Also, the } \\
\text { process can be assisted } \\
\text { with microwave, } \\
\text { plasma or electron } \\
\text { resonance to have more } \\
\text { control }\end{array}$ & $\begin{array}{l}\text { Preferably low } \\
\text { melting point } \\
\text { metals and } \\
\text { dielectrics }\end{array}$ & Yes & Uniformity is less & $\begin{array}{l}\text { High impurities } \\
\text { but low in case of } \\
\text { E-beam heating }\end{array}$ & $\begin{array}{l}\text { Moderate } \\
\text { deposition } \\
\text { rate } \\
(10-100 \mathrm{~nm} / \mathrm{min})\end{array}$ & $\begin{array}{l}\text { Cost-effective } \\
\text { in large-scale } \\
\text { production }\end{array}$ & $\begin{array}{l}\text { Facile method of } \\
\text { deposition, suitable } \\
\text { for large-scale } \\
\text { implementation, } \\
\text { good } \\
\text { reproducibility and } \\
\text { scalable method }\end{array}$ & $\begin{array}{l}\text { Poor uniformity, } \\
\text { low dense films } \\
\text { and becomes } \\
\text { expensive when } \\
\text { E-beam is used }\end{array}$ \\
\hline Sputtering & $\begin{array}{l}\text { Intense of vacuum } \\
\text { pressure, sputter gas } \\
\text { pressure, substrate and } \\
\text { target temperature and } \\
\text { sputter power }\end{array}$ & $\begin{array}{l}\text { Both metal and } \\
\text { dielectric porous } \\
\text { and thin films }\end{array}$ & No & $\begin{array}{l}\text { Excellent } \\
\text { uniformity }\end{array}$ & $\begin{array}{l}\text { Less impurities } \\
\text { and high-quality } \\
\text { films }\end{array}$ & $\begin{array}{l}\text { Variable } \\
\text { depositing } \\
\text { rates } \\
\text { depending on } \\
\text { the type of } \\
\text { sputtering } \\
\text { used }\end{array}$ & Expensive & $\begin{array}{l}\text { High-quality films, } \\
\text { wide variety of } \\
\text { materials can be } \\
\text { deposited, scalable } \\
\text { method }\end{array}$ & $\begin{array}{l}\text { Requires } \\
\text { sophisticated } \\
\text { arrangements and } \\
\text { cost-ineffective }\end{array}$ \\
\hline $\begin{array}{l}\text { Glancing } \\
\text { angle } \\
\text { deposition }\end{array}$ & $\begin{array}{l}\text { Vacuum, deposition } \\
\text { pressure, deposition } \\
\text { rate, vapor flux incident } \\
\text { angle and rotational } \\
\text { speed of the substrate }\end{array}$ & $\begin{array}{l}\text { Both metal and } \\
\text { dielectric porous } \\
\text { films }\end{array}$ & Yes & Uniformity is less & $\begin{array}{l}\text { Moderate to high } \\
\text { quality structures } \\
\text { can be formed }\end{array}$ & $\begin{array}{l}\text { Variable } \\
\text { deposition } \\
\text { rate }\end{array}$ & Moderate cost & $\begin{array}{l}\text { Morphology and } \\
\text { porosity can be } \\
\text { accurately } \\
\text { controlled. Highly } \\
\text { suitable for porous } \\
\text { films }\end{array}$ & Low dense films \\
\hline PECVD & $\begin{array}{l}\text { Substrate material and } \\
\text { temperature, gas } \\
\text { composition, flow rate, } \\
\text { temperature and } \\
\text { pressure, frequency }\end{array}$ & $\begin{array}{l}\text { Mainly dielectric } \\
\text { thin and porous } \\
\text { films }\end{array}$ & No & Good uniformity & $\begin{array}{l}\text { Very low } \\
\text { impurities and } \\
\text { high-quality films }\end{array}$ & $\begin{array}{l}\text { Variable and } \\
\text { high } \\
\text { deposition } \\
\text { rate }\end{array}$ & $\begin{array}{l}\text { Expensive but } \\
\text { APCVD is less } \\
\text { expensive } \\
\text { comparatively }\end{array}$ & $\begin{array}{l}\text { Industrial method, } \\
\text { high deposition and } \\
\text { uniformity, easily } \\
\text { coated even on } \\
\text { textured substrates }\end{array}$ & $\begin{array}{l}\text { Expensive } \\
\text { method, high } \\
\text { operating } \\
\text { temperature }\end{array}$ \\
\hline
\end{tabular}


Table 2. Cont

\begin{tabular}{|c|c|c|c|c|c|c|c|c|c|}
\hline $\begin{array}{l}\text { Fabrication } \\
\text { Techniques }\end{array}$ & $\begin{array}{l}\text { Controlling } \\
\text { Parameters }\end{array}$ & $\begin{array}{l}\text { Type of Coatings } \\
\text { Commonly } \\
\text { Fabricated } \\
\end{array}$ & Facileness & $\begin{array}{l}\text { Uniformity of the } \\
\text { Deposited Coating }\end{array}$ & Film Quality & $\begin{array}{c}\text { Deposition } \\
\text { Rate or Rate } \\
\text { of Fabrication }\end{array}$ & Cost & Advantages & Disadvantages \\
\hline Wet Etching & $\begin{array}{l}\text { Concentration of } \\
\text { etchant, temperature } \\
\text { and rate of waste } \\
\text { product removal }\end{array}$ & Textured surfaces & Yes & $\begin{array}{l}\text { Isotropic etching } \\
\text { results in uniform } \\
\text { etching }\end{array}$ & - & $\begin{array}{l}\text { High etching } \\
\text { rate. It } \\
\text { depends on } \\
\text { the etchant } \\
\text { used }\end{array}$ & Low-cost & $\begin{array}{l}\text { High selectivity, } \\
\text { high etching rate } \\
\text { and straight } \\
\text { forward method. } \\
\text { Often, used with } \\
\text { other fabrication } \\
\text { methods }\end{array}$ & $\begin{array}{l}\text { Most cases are } \\
\text { mask-assisted to } \\
\text { protect the } \\
\text { substrate and no } \\
\text { precision control }\end{array}$ \\
\hline Dry Etching & $\begin{array}{l}\text { Chamber pressure, gas } \\
\text { flow rate and bias } \\
\text { control }\end{array}$ & Textured surfaces & Yes & $\begin{array}{l}\text { Uniformity is } \\
\text { obtained in tradeoff } \\
\text { with rate and } \\
\text { selectivity }\end{array}$ & - & $\begin{array}{l}\text { Etching rate } \\
\text { depends on } \\
\text { gas or ions } \\
\text { used }\end{array}$ & Low-cost & $\begin{array}{l}\text { Cheap and } \\
\text { eliminates the use } \\
\text { of dangerous } \\
\text { solvents and acids }\end{array}$ & $\begin{array}{l}\text { No precision } \\
\text { control and some } \\
\text { employed gases } \\
\text { are corrosive and } \\
\text { toxic }\end{array}$ \\
\hline Lithography & $\begin{array}{l}\text { Resist film thickness } \\
\text { and uniformity, } \\
\text { exposed radiation }\end{array}$ & $\begin{array}{l}\text { Wide variety of } \\
\text { structures and } \\
\text { surfaces }\end{array}$ & No & $\begin{array}{l}\text { Depends on the } \\
\text { etching after } \\
\text { lithographic } \\
\text { exposure }\end{array}$ & - & - & $\begin{array}{c}\text { Depends on } \\
\text { the radiation } \\
\text { used. } \\
\text { Low-cost } \\
\text { approaches } \\
\text { exist }\end{array}$ & $\begin{array}{l}\text { Process parameters } \\
\text { can be precisely } \\
\text { controlled. Time } \\
\text { efficient, simple and } \\
\text { high throughput }\end{array}$ & $\begin{array}{l}\text { Sophisticated } \\
\text { equipment is } \\
\text { required. } \\
\text { Inefficiency in } \\
\text { generating 3D } \\
\text { structures }\end{array}$ \\
\hline $\begin{array}{l}\text { Nano imprint } \\
\text { lithography }\end{array}$ & $\begin{array}{l}\text { Precision of the mold, } \\
\text { applied pressure. }\end{array}$ & $\begin{array}{l}\text { Wide variety of } \\
\text { structures and } \\
\text { surfaces, and } \\
\text { biomimetic coatings }\end{array}$ & Yes & High uniformity & $\begin{array}{l}\text { Quality of the } \\
\text { structures } \\
\text { depends on the } \\
\text { mold }\end{array}$ & $\begin{array}{l}\text { Rapid } \\
\text { fabrication if } \\
\text { mold is ready }\end{array}$ & $\begin{array}{c}\text { Cost-effective } \\
\text { in large-scale } \\
\text { production }\end{array}$ & $\begin{array}{l}\text { Simple, } \\
\text { cost-effective, } \\
\text { time-effective and } \\
\text { large area } \\
\text { fabrication is } \\
\text { possible }\end{array}$ & $\begin{array}{l}\text { Usually, the } \\
\text { cleaning of the } \\
\text { compressed resist } \\
\text { demands reactive } \\
\text { ion etching } \\
\text { process. Mold } \\
\text { fabrication } \\
\text { requires advanced } \\
\text { technologies }\end{array}$ \\
\hline $\begin{array}{c}\text { Soft } \\
\text { lithography }\end{array}$ & $\begin{array}{l}\text { Depends on the } \\
\text { elastomeric stamp, } \\
\text { temperature and } \\
\text { pressure applied }\end{array}$ & $\begin{array}{l}\text { Wide variety of } \\
\text { nano-structures and } \\
\text { surfaces. Preferably } \\
\text { polymer coatings }\end{array}$ & Yes & $\begin{array}{l}\text { Excellent surface } \\
\text { uniformity }\end{array}$ & $\begin{array}{l}\text { Good quality } \\
\text { structures }\end{array}$ & $\begin{array}{l}\text { Rapid } \\
\text { fabrication }\end{array}$ & Low-cost & $\begin{array}{l}\text { Simple, fast, good } \\
\text { adhesion, high } \\
\text { resolution with } \\
\text { high precision }\end{array}$ & $\begin{array}{l}\text { It depends on } \\
\text { lithography } \\
\text { techniques to } \\
\text { create master } \\
\text { patterns }\end{array}$ \\
\hline
\end{tabular}




\subsubsection{Miscellaneous Techniques}

Specific techniques such as photo-aligning and photopatterning, which are used to fabricate LCDs, are also employed for preparing optical ARC films having controlled surface topologies. The approach involves a phase-separation which is obtained in liquid crystal films deposited on the substrate in such a way that a nano-corrugated surface is produced. One such work by Ibn-Elhaj and Schadt developed an optical polymer film using photo-aligning and photopatterning techniques. The coating is applied to the glass, and it exhibited a very low reflectivity of $0.1 \%$ and a high transmission of about $99.1 \%$ within the wavelength range of 400-700 $\mathrm{nm}$ [95].

\section{Antireflection Coating Materials}

Antireflective coating's primary task is to minimize the Fresnel reflection loss and to assist the propagation of light into the PV bulk materials with maximum light transmission as possible. The criteria in which the effectiveness of the coating revolves are the material with which ARC is made of, the structure of ARC (especially top surface), and fabrication techniques used to prepare an AR coating. Regarding this, materials play a crucial role that decides the properties, including transparency, mechanical robustness, weight, corrosion, thermal and chemical inertness. Also, the fabrication method depends highly on material characteristics and influences the cost factor. In this section, the AR coating materials are classified and reviewed with various structures, preparation methods, maximum or average transmission exhibited, and with other features. Tables under each section also list the research potential for individual reported study. The classification of ARC material is represented below (Figure 14).

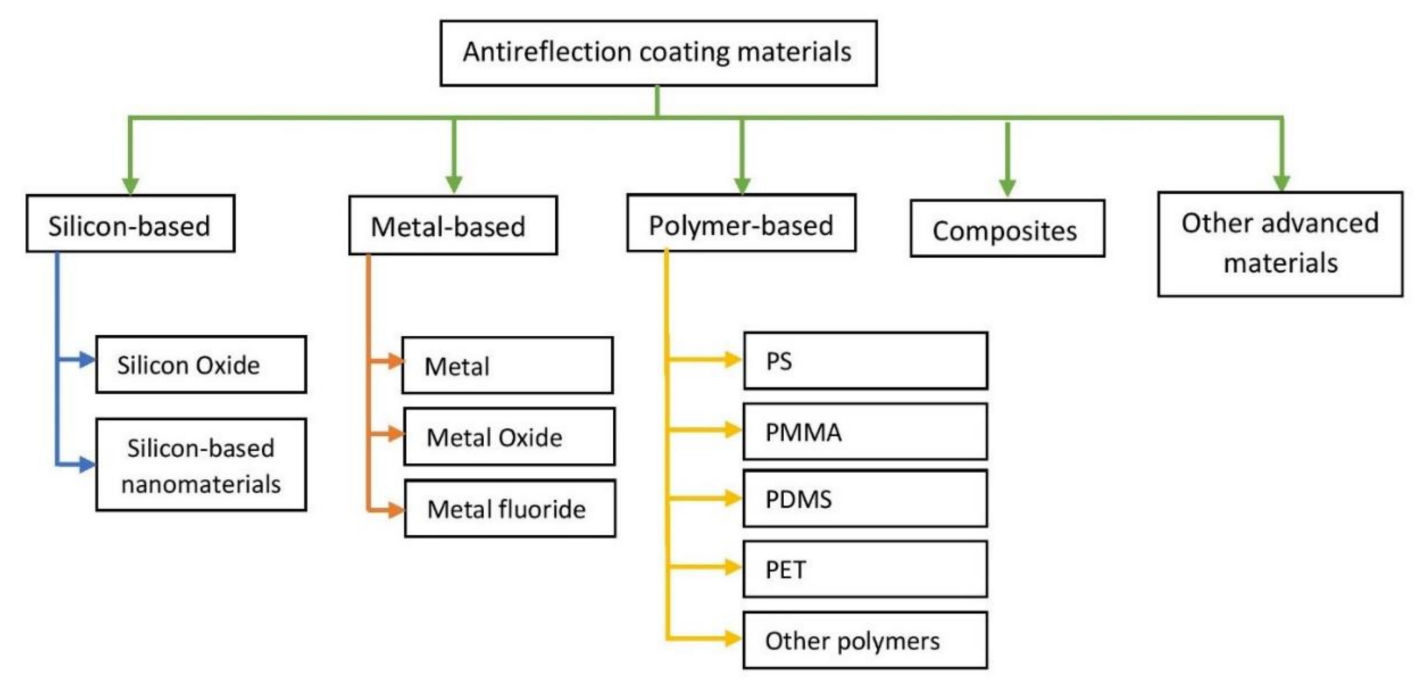

Figure 14. Classification of antireflection coating materials.

\subsection{Silicon-Based}

Silicon is a material that is exceptionally explored in the area of antireflection coatings covering from porous silicon (PSi) to silicon nanowires (SiNWs). Though silicon is subjected to undesirable reflection losses (reflectivity higher than $30 \%$ ), the compatibility with Si solar cells and its use in the photovoltaic industry makes it indispensable. The reflection loss is mainly attributed due to its high index of refraction $\left(n_{\mathrm{si}}>3.4\right)$, and thus, it is crucial to design an efficacious light trapping silicon surface structure to minimize the reflection to amplify the light availability for PV cells. Over the decade, researchers have contributed a lot to fabricate an effectual antireflection coating with Si using different fabrication techniques. 


\subsubsection{Silicon and Silicon Dioxide (Silica)}

Silicon oxide is extensively used in several optical applications because of its high stability, low refractive index, and is inexpensive. Numerous studies related to antireflective coatings have been reported with silica material to boost light transmission through various fabrication processes, such as wet chemical etching [96], colloidal lithography [97], interference lithography [98], and sol-gel process. The majority of studies focusing on monolayer silica is formed by dipping the substrates in sols made from tetraethyl orthosilicate (TEOS) and a combination of TEOS and methyl triethoxysilane (MTES) or colloidal silica solution. In a study, Mahadik et al. [99] fabricated a single layer $\mathrm{SiO}_{2}$ coating from a silica sol and deposited on a cleaned glass substrate using a dip-coating methodology. Further, it is subjected to the heat-treatment process maintained at a temperature of $400{ }^{\circ} \mathrm{C}$. High transmittance of about $97.5 \%$ at $500 \mathrm{~nm}$ wavelength is achieved by optimizing the porosity and coating thickness. The thickness is controlled by varying the substrate lifting speed from the sol, and the porosity is changed with the aid of heat treatment processes and polymer additives. The sol-gel deposition has some drawbacks such as inhomogeneous film deposition, wettability problems, and need for elevated temperature for drying. Nagel et al., on the other hand, produced a novel porous silica ARC through remote plasma enhanced chemical vapor deposition (RPECVD) [100]. The porous $\mathrm{SiO}_{2} \mathrm{SLARC}$ deposited on the two sides of the glass pane boosted the transmission, and at a particular wavelength, the enhancement of transmittance was found to reach $100 \%$ from $91.7 \%$. Moreover, with the use of porous $\mathrm{SiO}_{2}$ DLARC on either side of the glass pane, the transmission weighted in the wavelength span of 400-1150 nm is improved from $91.6 \%$ to $99.4 \%$.

Double layer porous silicon (PSi) ARC proves to be effective in visible wavelength region [101]. For example, a single layer PSi ARC developed achieved an effective reflectance $\sim 7 \%$ in the wavelength region of 400-1000 nm, whereas double-layer PSi ARC achieved below 3\% reflectance as experimented by Strehlke et al. [102]. Also, an effective reflectivity of 5.8\% is obtained in AM1.5 spectral distribution for double-layer PSi ARC fabricated with the help of a chemical stain etching method in 400-1100 nm wavelength range according to the study by Lipinski et al. [103]. Further studies on single and double-layer ARC's were performed by Remache et al. [83]. According to the study, the single-layer PSi ARC deposited on $n+p-$ junction solar cells achieved an effective reflectance of 9\% in $400-1000$ nm wavelength range. Further, the deposition of a silicon oxide film on the PSi ARC through the PECVD technique improved the stability and passivation properties of the double layer ARC. The SiOx layers of $105 \mathrm{~nm}$ thickness, together with the PSi layer, has reduced the effective reflectance to $3.8 \%$. Usually, to study the anti-reflective properties of AR coatings, the transmittance of prepared ARCs was compared with that of glass substrates, which is taken as the reference sample. Wang et al. [104] designed a novel substrate by combining a metal-organic CVD (MOCVD) prepared boron-doped zinc oxide (BZO) with $\mathrm{SiO}_{2}$ coatings. The coating is fabricated through the sol-gel dip-coating method. When compared to the glass substrate, the outcome of the AR coatings was illustrious in near-infrared and UV spectral ranges. The thickness and the RI of the prepared ARC were $90 \mathrm{~nm}$ and 1.28, respectively, achieving the destructive interference conditions and thus, providing an average transmittance of $93.4 \%$ in $400-1000 \mathrm{~nm}$ range and the maximum transmittance of $95.5 \%$ was obtained at $700 \mathrm{~nm}$. When this novel substrate is applied to thin-film a-Si solar cells, the efficiency was enhanced from $9.83 \%$ to $10.24 \%$.

AR properties of PV can also be enhanced by texturing the Si wafer above which ARC is deposited. For instance, Cao et al. [105] demonstrated the AR effect of $\mathrm{SiO}_{2}$ thin film on the pyramidal shape textured mono c-Si wafer. The textured surface on the polished silicon wafer was obtained by etching. The $\mathrm{SiO}_{2}$ film was then deposited and further subjected to thermal oxidation. The average reflectance of fabricated pyramidal textured Si wafer (Figure 15a,b) was 15.6\% in 400-900 nm wavelength range, which is reduced further by $\mathrm{SiO}_{2}$ coating. The $\mathrm{SiO}_{2}$ coating with $111.9 \mathrm{~nm}$ thickness demonstrated a reflectance of about $3.8 \%$ in the visible spectrum, as shown in Figure 15c. Some studies also show high mechanical strength as depicted by Guo et al. [106] in which a silica thin film of a closed-surface structure is formed in a single dipping process. The thickness and hence the refractive index of the film 
is optimized by controlling the withdrawing speed and adjusting acid-catalyzed sol-gel constituents. A high transmittance of $97.1 \%$ is obtained with an index of refraction around 1.25-1.27. This coating claims to have robust mechanical properties with $5 \mathrm{H}$ pencil hardness and possess high temperature and moisture resistance, owing to the lack of surface voids. Another study by Agustin-Saenz et al. [107] indicates that the silica ARC can also be used in the Concentrated Photovoltaics (CPVs) application. In this study, a broadband anti-reflective property is obtained by stacking multiple layers of silica for the CPVs application. Under the reference AM 1.5 solar spectral irradiance, the ARC stack provided a $7.2 \%$ increase in transittance when coated on both sides with respect to bare glass in $300-2000 \mathrm{~nm}$ wavelength range.

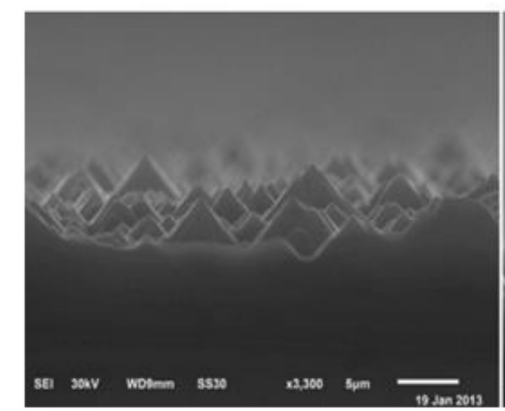

(a)

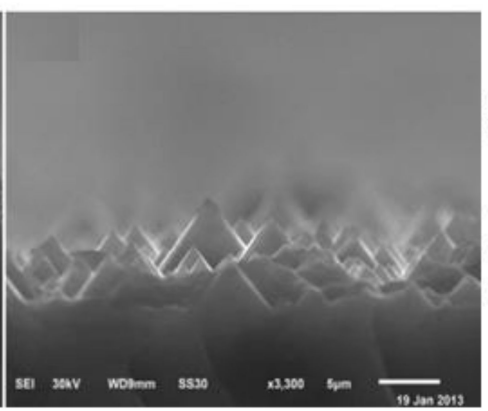

(b)

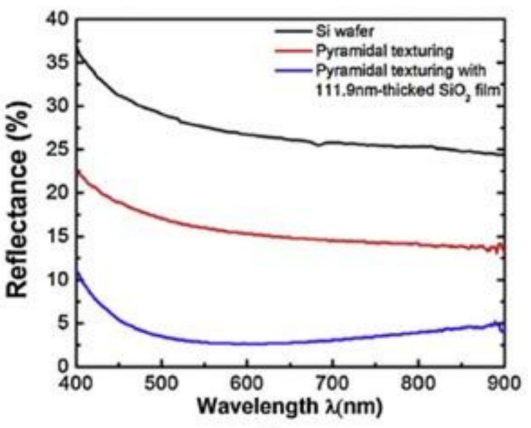

(c)

Figure 15. Pyramidal textured $\mathrm{SiO}_{2}$ surface (a) before and (b) after thermal oxidation. (c) Comparison of reflectance in terms of wavelength for Si wafer surface, pyramidal textured Si surface without and with $\mathrm{SiO}_{2}$ coating Reprinted with permission [105]; 2015, Elsevier.

\subsubsection{Silicon-Based Nanomaterials}

Nanotechnologies are used to obtain necessary textured surfaces to enhance the antireflection properties. Numerous techniques have been experimented to obtain silicon nanostructures either in a bottom-up scheme or top-down scheme. Among recent developments, the metal-assisted chemical etching (MCAE) presents as an efficient and low-cost technique for various $\mathrm{Si}$ nanostructures such as $\mathrm{Si}$ Nanowires (SINWs) [108], porous SiNWs, and Si nanopores [109]. This approach has been effectively used for fabricating large-area silicon nanowires arrays and reported to have increased absorption of incident light and light scattering [110]. Li et al. reported Si nanowire (SiNW) arrays as beneficial antireflection coatings and analyzed the dependence of experimental parameters on the morphological structure and AR properties [111]. It was observed that the fabrication parameters such as deposition time, etching time, $\mathrm{H}_{2} \mathrm{O}_{2}$, and $\mathrm{HF}$ concentration influences on the AR properties of the textured multi-crystalline silicon sample. The research also showed that a tapering structure for nanowire arrays is more beneficial to attain outstanding AR property. Under an optimized condition, the nanowire array with a tapering structure exhibited an excellent antireflection ability with a $\sim 5.6 \%$ reflectivity. Nielsen et al. [112] focused on large-area antireflective surfaces deposited on the commonly used glass in PV application with low-cost processing techniques compared to other technologies. In this work, they prepared a nano-porous silica layer with $100 \mathrm{~nm}$ thickness, and the obtained index of refraction ranges between 1.3 and 1.47. At an optimized state, the maximum transmission achieved an increase of $3.6 \%$ for single side coating at $550 \mathrm{~nm}$ wavelength, and an increase of $3.1 \%$ is obtained for $400-1100 \mathrm{~nm}$ spectral range when compared with uncoated glass sample. Groep et al. fabricated a nanocylinder structured ARC made of silica using combined sol-gel and substrate-conformal soft-imprint lithography techniques [113]. The constructed structure attained an average reflectance of $0.57 \%$ in $425-700 \mathrm{~nm}$ wavelength range and $0.97 \%$ in $425-1000 \mathrm{~nm}$ wavelength range. Low refractive index thin film is vital in optics, Opto- and micro-electronics, and so as for PV application. Sobahan et al. [114] demonstrated a nanostructured porous $\mathrm{SiO}_{2}$ film for antireflection coating. In this study, the $\mathrm{SiO}_{2}$ films are fabricated by using the GLAD technique in such a way that the film is deposited at an angle of $85^{\circ}$, and it 
possessed a refractive index (RI) of 1.08 at $633 \mathrm{~nm}$. A four-layer $\mathrm{SiO}_{2}$ film composed of alternative dense (RI-1.45) and light film (RI-1.08) is constructed, and the reflectance spectra are studied at incident angles of $0^{\circ}, 30^{\circ}$, and $45^{\circ}$ in the span of $400-800 \mathrm{~nm}$ wavelength. The microstructure and the surface morphology are also analyzed by using an SEM. In the $400-800 \mathrm{~nm}$ wavelength range, the mean reflectance is about $0.04 \%, 0.3 \%, 0.61 \%$ at normal incidence, $30^{\circ}$, and $45^{\circ}$ incident angles respectively, and the average transmittance obtained is $99.3 \%$ marking a very high transmission, and low absorption of nanostructured $\mathrm{SiO}_{2}$ layers is obtained. In another approach by Jia et al., a five-layer coating having a total thickness of $250 \mathrm{~nm}$ was constructed by using a sol-gel technique that acted as a graded-refractive index thin film [115]. The RI of the ARC was varied from 1.33 to 1.11, with each layer having a thickness of $50 \mathrm{~nm}$, and the hollow diameters of the silica particles range from 0 to $38 \mathrm{~nm}$. At normal incidence, the average transmittance achieved was $99.04 \%$, and the highest transmittance obtained exceeded $99 \%$ at incident angles ranging from $0^{\circ}$ to $45^{\circ}$ in $380-1600 \mathrm{~nm}$ wavelength range.

Recent trends in developing hydrophobic surfaces to impart self-cleaning property along with antireflectivity for glass covers of the solar cell is indispensable. For instance, Zhi et al. [116] produced a durable hydrophobic surface with AR properties on the glass cover of solar cells. The steps involved in the fabrication of such a surface is shown in Figure 16a. The coating is developed in the form of a dual-scale structure in which initially, a 3D crosslink network of nanopores is established, and then, the silica nanoparticles in a sol were added to the nanopore structure. This reduces the pore size, and a refractive index of 1.3471 is obtained. The transmittance spectra are represented in Figure 16b. An average transmittance of $97 \%$ was attained when compared to $90 \%$ transmittance possessed by a bare glass substrate. This coating surface has desirable characteristics of superhydrophobicity with a static Water Contact Angle (WCA) of $157.9^{\circ}$ (Figure 16c). Moreover, the surface exhibited excellent stability against water drops, strong acid, alkali, and it has a $4 \mathrm{H}$ pencil hardness making it suitable for glass covers in PV application. Another study by Fangting Chi et al. [117] deals with a mechanically robust and self-cleaning ARC in which hydrophobic silica nanoparticles with an organo-silica binder is used. This coating exhibited a hardness of $4.2 \mathrm{GPa}$, and a WCA of $161^{\circ}$ and high transmittance of $99.9 \%$ at a wavelength of $550 \mathrm{~nm}$ is obtained owing to the combination of hydrophobic silica nanoparticles and organo-silica binder. A double function $\mathrm{SiO}_{2}-\mathrm{DMS}$ coating [118] was developed by Zihui Liang et al. in which a fluorine-free material is employed as a modifier to obtain water-repellent ability. The $\mathrm{SiO}_{2}$-DMS coating established a water contact angle of $153^{\circ}$, and an optimized coating exhibited an average transmittance of $96.07 \%$ in $300-800 \mathrm{~nm}$ wavelength range. 

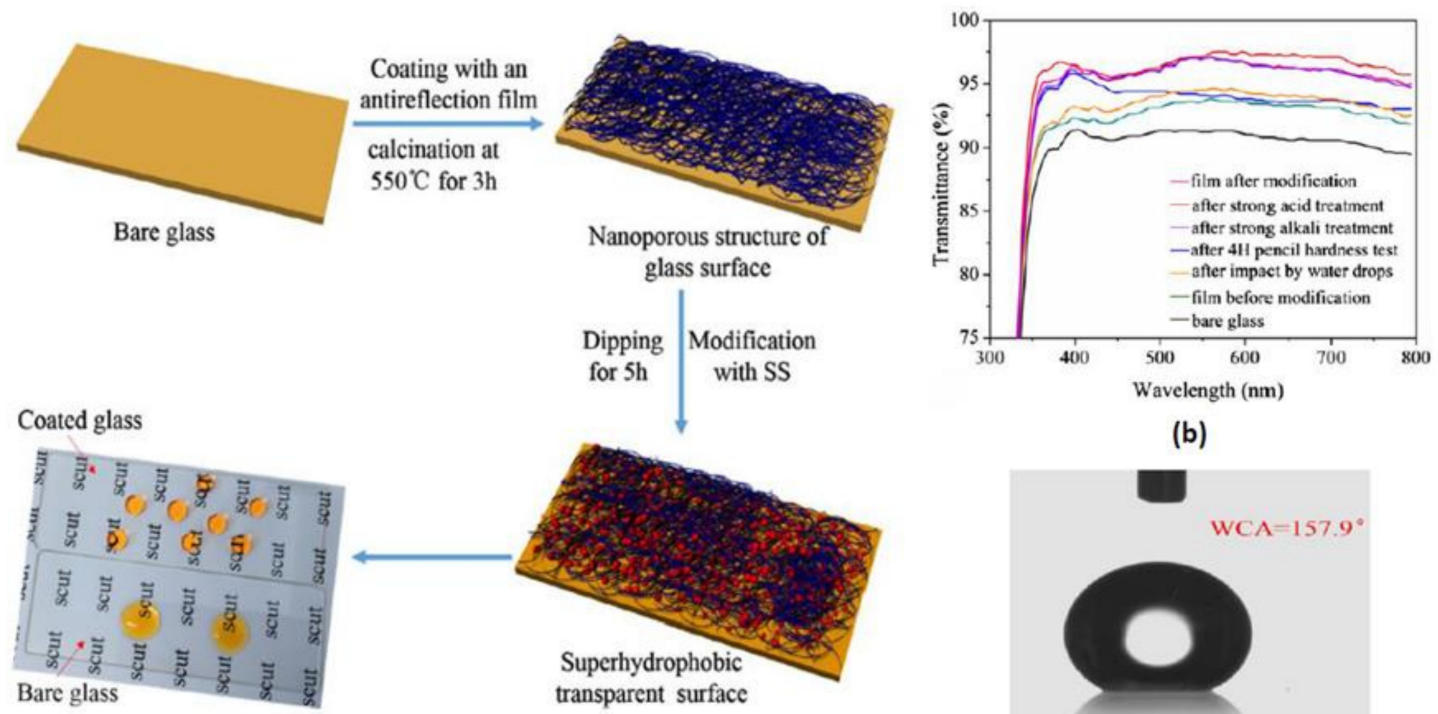

(b)

(a)

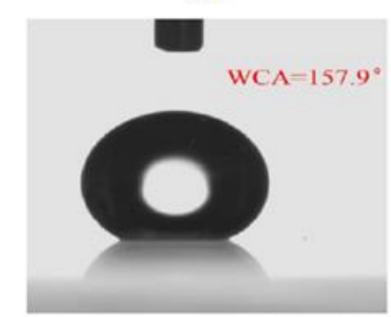

(c)

Figure 16. (a) Illustration of various steps in fabricating durable anti-reflection transparent superhydrophobic surfaces. (b) Comparison of transmittance for glass substrates with various coatings and without coatings with respect to wavelength. (c) Water droplet contact angle on the superhydrophobic coating. Reprinted with permission [116]; 2018, Elsevier.

Silicon nanospheres are also of great interest in designing an effective AR coating, especially in perovskite solar cells, which has vast prospects in the PV industry. Luo et al. enhanced the efficiency of the perovskite solar cells with silica nanosphere ARCs from $14.81 \%$ to $15.82 \%$ [119]. In this research, $\mathrm{SiO}_{2}$ nanosphere AR coatings (Figure $17 \mathrm{a}-\mathrm{c}$ ) are obtained from an aged silica sol and is deposited by utilizing the spin-coating technique in which the thickness and the microstructure are regulated by varying the speed of the spin. The optimized $\mathrm{SiO}_{2}$ nanosphere coating is reported to have the highest transmittance of $96.1 \%$ at the wavelength of $550 \mathrm{~nm}$, and the transmittance spectra are represented in Figure 17d. It is also observed that with this coating, the performance of the PV is less affected by the angle of the incident light. Similarly, Li et al. [120] worked on CIGS solar cells with novel ARC structures consisting of continuous $\mathrm{SiO}_{2}$ film and monodispersed $\mathrm{SiO}_{2}$ nanospheres (NSs) array as a result of which the PCE is enhanced from $11.66 \%$ to $12.59 \%$. This structure is obtained by mimicking a moth-eye-like nanostructure with a periodic sub-wavelength protuberance. The solar transmittance of $\mathrm{SiO}_{2} \mathrm{NSs} / \mathrm{SiO}_{2}$ film in the visible region on average is improved by $7.02 \%$ and with a maximum improvement of $8.21 \%$. 


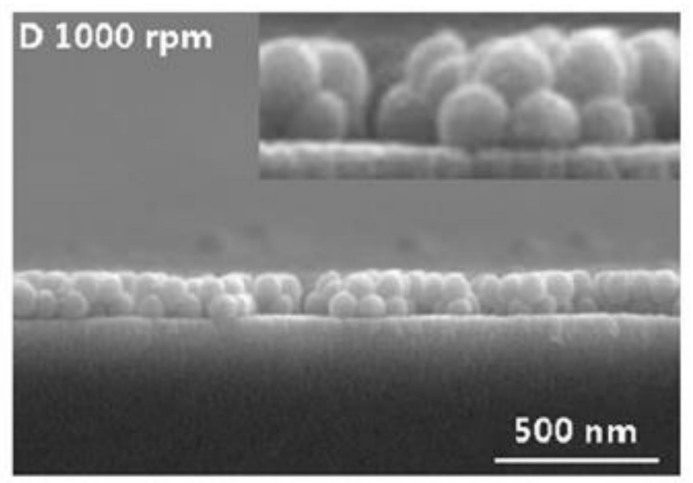

(a)

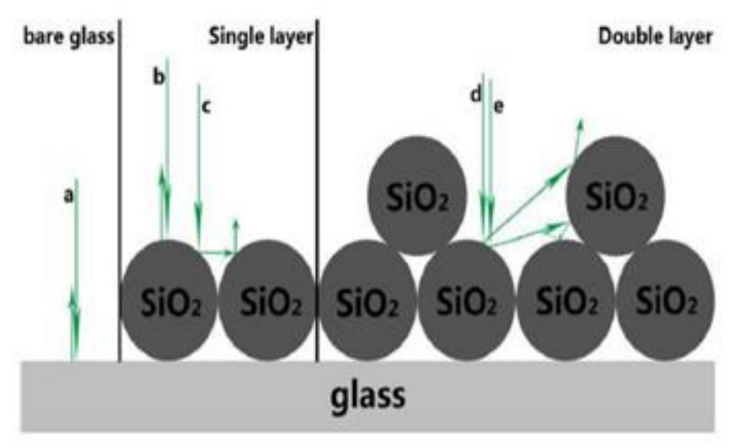

(c)

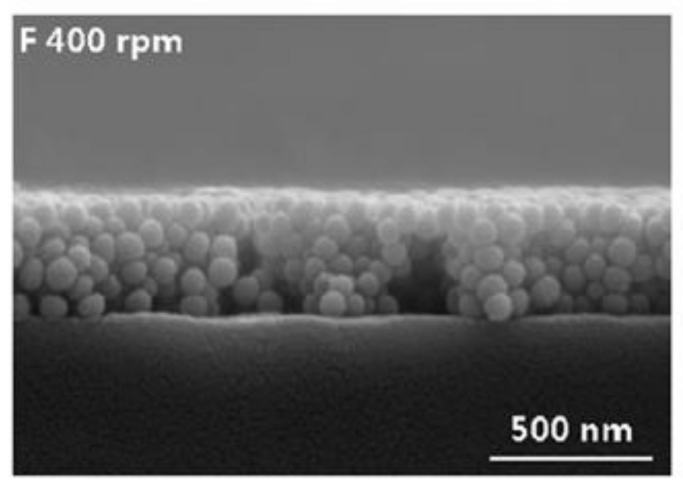

(b)

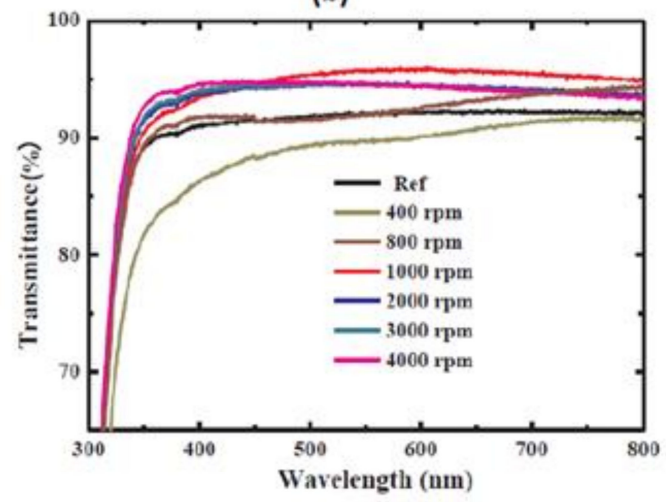

(d)

Figure 17. (a,b) FESEM images of spherical $\mathrm{SiO}_{2}$ coating deposited on glass substrates with various spin-coating speeds. (c) Schematic illustration of the light interaction with $\mathrm{SiO}_{2}$ sphere-based ARCs. (d) Variation of transmittance for spherical $\mathrm{SiO}_{2}$ based AR coatings on glass substrate at various speeds (Ref-Glass sample without coating). Reprinted with permission [119]; 2018, Elsevier.

Wang et al. prepared an ARC consisting of hydrogenated nanocrystalline Si (nc-Si:H) nanorod arrays and is deposited on nickel nano-cone substrate via high-frequency PECVD [121]. The average diameter and height of the optimized nc-Si:H nanorod structures were $200 \mathrm{~nm}$ and $700 \mathrm{~nm}$, respectively. This coating showed a low reflectance achieving below 5\% at normal incidence in 400-1100 nm wavelength range. Duttagupta et al. reported a plasma-deposited silicon nitride coating for Si wafer solar cells [122]. In this study, the refractive index of the coating is adjusted from 1.9 to 2.7 , and it is found that at an index of refraction of 2, corresponding to the $70 \mathrm{~nm}$ film thickness, a weighted average reflectance of less than $2.5 \%$ and a weighted average transmittance more than $97 \%$ on mono-Si wafers. Also, this film shows excellent surface passivation quality. Prasad et al. deposited silicon nitride (SiNx) ARC on multi-crystalline $\mathrm{Si}$ (mc-Si) wafers. The surface of the wafer exhibited a reflectivity of less than $10 \%$ in the $350-800 \mathrm{~nm}$ wavelength range [123]. Huang et al. reported broadband and Omni-direction antireflection coating with an aperiodic array of silicon nanotips structures that effectively suppresses the reflection from UV region to visible spectrum for a wide range of incident angles [29]. The summarized table for silicon-based antireflection coatings is given in Table 3. 
Table 3. Silicon based antireflection coatings.

\begin{tabular}{|c|c|c|c|c|c|c|c|c|}
\hline $\begin{array}{c}\text { AR Coating } \\
\text { Material }\end{array}$ & ARC Structure & $\begin{array}{l}\text { Fabrication } \\
\text { Technology }\end{array}$ & Reflectance (\%) & $\begin{array}{c}\text { Transmittance } \\
(\%)\end{array}$ & $\begin{array}{l}\text { Wavelength } \\
\text { (nm) }\end{array}$ & Features & Research Potential & Reference \\
\hline Silicon & Nanowires (NWs) & $\begin{array}{l}\text { Ag catalyzed } \\
\text { chemical etching }\end{array}$ & 5.6 & - & $250-800$ & $\begin{array}{l}\text { Large scale SiNWs } \\
\text { arrays can be prepared } \\
\text { using MACE method }\end{array}$ & $\begin{array}{l}\text { Experimental analysis } \\
\text { of the increase in PCE } \\
\text { using this coating }\end{array}$ & [111] \\
\hline $\begin{array}{l}\text { Porous silicon } \\
\quad \text { (PSi) }\end{array}$ & $\begin{array}{ll}\text { (i) } & \text { Single layer PSi } \\
\text { (ii) } & \text { Doube layer PSi }\end{array}$ & $\begin{array}{l}\text { Electrochemical } \\
\text { process }\end{array}$ & $\begin{array}{ll}\text { (i) } & \sim 7 \\
\text { (ii) } & \sim 3\end{array}$ & - & $400-1000$ & $\begin{array}{l}\text { Porosity can be varied } \\
\text { by modulating current } \\
\text { density in the } \\
\text { electochemical process }\end{array}$ & $\begin{array}{l}\text { Effect of this coating on } \\
\text { various solar cells to } \\
\text { find its suitable } \\
\text { application }\end{array}$ & [102] \\
\hline $\begin{array}{l}\text { Porous silicon } \\
\quad \text { (PSi) }\end{array}$ & Double PSi layer & $\begin{array}{l}\text { Chemical stain } \\
\text { etching }\end{array}$ & 5.8 & - & $400-1100$ & $\begin{array}{l}\text { Low reflectivity } \\
\text { comparable to SiNx } \\
\text { coating }\end{array}$ & $\begin{array}{l}\text { Effect of this coating on } \\
\text { various solar cells to } \\
\text { find its suitable } \\
\text { application }\end{array}$ & [103] \\
\hline $\begin{array}{l}\text { Hydrogenated } \\
\text { nanocrystalline Si }\end{array}$ & Nanorod arrays & $\begin{array}{l}\text { High frequency } \\
\text { plasma enhanced } \\
\text { vapor deposition }\end{array}$ & $<5$ & - & $400-1100$ & $\begin{array}{l}\text { Broadband } \\
\text { antrireflection coating } \\
\text { with very low } \\
\text { reflectance }\end{array}$ & $\begin{array}{l}\text { Experimental analysis } \\
\text { of the increase in PCE } \\
\text { using this coating }\end{array}$ & [121] \\
\hline Silica & $\begin{array}{l}\text { Single layer } \\
\text { nanoporous }\end{array}$ & Sol-gel dip-coating & - & 97.5 & 500 & $\begin{array}{l}\text { Cost-effective and } \\
\text { straight forward } \\
\text { technique. }\end{array}$ & $\begin{array}{l}\text { Transmittance can be } \\
\text { improved in the whole } \\
\text { visible range }\end{array}$ & [99] \\
\hline Silica & $\begin{array}{l}\text { Double layer porous } \\
\text { film }\end{array}$ & Remote PECVD & - & 99.4 & $400-1150$ & $\begin{array}{l}\text { The low refractive } \\
\text { index of the order of } \\
1.11 \text { can be fabricated }\end{array}$ & $\begin{array}{l}\text { Power conversion } \\
\text { efficiency changes can } \\
\text { be analyzed using this } \\
\text { coating }\end{array}$ & [100] \\
\hline Silica & Single layer $\mathrm{SiO}_{2}$ & $\begin{array}{l}\text { Chemical etching and } \\
\text { thermal oxidation }\end{array}$ & 15.6 & - & $400-900$ & $\begin{array}{l}\text { Uses pyramidal } \\
\text { textured } \mathrm{Si} \text { wafer on } \\
\text { which } \mathrm{SiO}_{2} \text { is deposited }\end{array}$ & $\begin{array}{l}\text { Research can be } \\
\text { performed to reduce } \\
\text { the reflectance further }\end{array}$ & [105] \\
\hline Silica & $\begin{array}{l}\text { Closed-surface silica } \\
\text { ARC }\end{array}$ & $\begin{array}{l}\text { Acid catalyst sol-gel } \\
\text { method }\end{array}$ & - & 97.1 & $300-1200$ & $\begin{array}{l}\text { Robust mechanical } \\
\text { properties with } 5 \mathrm{H} \\
\text { pencil hardness and } \\
\text { high moisture and } \\
\text { high-temperature } \\
\text { resistance }\end{array}$ & $\begin{array}{l}\text { Effect of this coating on } \\
\text { various solar cells to } \\
\text { find its suitable } \\
\text { application }\end{array}$ & [106] \\
\hline Silica & $\begin{array}{l}\text { Multi-layer stacks of } \\
\text { silica }\end{array}$ & $\begin{array}{l}\text { Sol-gel and } \\
\text { evaporation induced } \\
\text { self-assembly (EISA) } \\
\text { technique }\end{array}$ & - & $\begin{array}{l}7.2 \% \text { increase } \\
\text { than bare glass }\end{array}$ & $300-2000$ & $\begin{array}{l}\text { Suitable for } \\
\text { Concentrated } \\
\text { photovoltaic (CPV) } \\
\text { application }\end{array}$ & $\begin{array}{l}\text { Stability, reliability and } \\
\text { environmental effects } \\
\text { of/on the coating can be } \\
\text { analyzed }\end{array}$ & [107] \\
\hline
\end{tabular}


Table 3. Cont.

\begin{tabular}{|c|c|c|c|c|c|c|c|c|}
\hline $\begin{array}{l}\text { AR Coating } \\
\text { Material }\end{array}$ & ARC Structure & $\begin{array}{l}\text { Fabrication } \\
\text { Technology }\end{array}$ & Reflectance (\%) & $\begin{array}{c}\text { Transmittance } \\
\text { (\%) }\end{array}$ & $\begin{array}{l}\text { Wavelength } \\
\quad(\mathrm{nm})\end{array}$ & Features & Research Potential & Reference \\
\hline Silica & Nanoporous & Dip or spray coating & - & $\begin{array}{l}3.1 \% \text { increase } \\
\text { than bare glass }\end{array}$ & $400-1100$ & $\begin{array}{l}\text { Large area and } \\
\text { cost-effectiveARC for } \\
\text { solar glasses }\end{array}$ & $\begin{array}{l}\text { Transmission can be } \\
\text { enhanced further, and } \\
\text { efficiency analysis can } \\
\text { be made }\end{array}$ & [112] \\
\hline Silica & Nanocylinder & $\begin{array}{l}\text { Sol-gel and } \\
\text { softimprint } \\
\text { lithography }\end{array}$ & 0.57 & - & $425-700$ & $\begin{array}{l}\text { Large area fabrication, } \\
\text { cost-effective, and } \\
\text { simple methods }\end{array}$ & $\begin{array}{l}\text { Improvement of } \\
\text { transmittance in } \\
\text { broadband wavelength } \\
\text { range and efficiency } \\
\text { analysis can be } \\
\text { considered }\end{array}$ & [113] \\
\hline Silica & $\begin{array}{l}\text { Four-layer } \\
\text { Nano-porous } \mathrm{SiO} 2\end{array}$ & $\begin{array}{l}\text { Glancing angle } \\
\text { deposition technique }\end{array}$ & 0.04 & - & $400-800$ & $\begin{array}{l}\text { Very negligable } \\
\text { reflectance }\end{array}$ & $\begin{array}{l}\text { Experimental analysis } \\
\text { of the increase in PCE } \\
\text { using this coating }\end{array}$ & [114] \\
\hline Silica & $\begin{array}{l}\text { Five-layer hollow } \\
\text { silica nanoparticles }\end{array}$ & Dip coating method & - & 99.04 & $380-1600$ & $\begin{array}{l}\text { Broadband } \\
\text { antrireflection coating }\end{array}$ & $\begin{array}{l}\text { Effect of this coating on } \\
\text { various solar cells to } \\
\text { find its suitable } \\
\text { application }\end{array}$ & [115] \\
\hline Silica & Nanopore & $\begin{array}{l}\text { Phase separation } \\
\text { process, calcination, } \\
\text { dip coating }\end{array}$ & - & 97 & $400-800$ & $\begin{array}{l}\text { The coating is resistant } \\
\text { to water, strong alkali } \\
\text { and acids possessing } \\
4 \mathrm{H} \text { pencil hardness }\end{array}$ & $\begin{array}{l}\text { Experimental analysis } \\
\text { of the increase in PCE } \\
\text { using this coating }\end{array}$ & [116] \\
\hline Silica & Nanoparticles & $\begin{array}{l}\text { Stober and dip } \\
\text { coating method }\end{array}$ & - & 99.9 & 550 & $\begin{array}{l}\text { Robust and } \\
\text { self-cleaning ARCs }\end{array}$ & $\begin{array}{l}\text { Effect of this coating on } \\
\text { various solar cells to } \\
\text { find its suitable } \\
\text { application }\end{array}$ & [117] \\
\hline Silica & $\begin{array}{l}\text { Double function } \\
\mathrm{SiO}_{2} \text {-DMS coating }\end{array}$ & Sol-gel method & - & 96.07 & $300-800$ & $\begin{array}{l}\text { Fluorine-free materials } \\
\text { were used as a modifier } \\
\text { to obtain water } \\
\text { repellent capability }\end{array}$ & $\begin{array}{l}\text { Effect of this coating on } \\
\text { various solar cells to } \\
\text { find its suitable } \\
\text { application }\end{array}$ & [118] \\
\hline Silica & Nanosphere & Spin coating & - & $3.8 \%$ increase & $400-800$ & $\begin{array}{l}\text { PCE improved from } \\
14.81 \text { to } 15.82 \% \text { for PSC } \\
\text { device }\end{array}$ & $\begin{array}{l}\text { Improvement of } \\
\text { transmittance in } \\
\text { broadband wavelength } \\
\text { range and stability, the } \\
\text { durability of the film } \\
\text { can be considered }\end{array}$ & [119] \\
\hline
\end{tabular}


Table 3. Cont

\begin{tabular}{|c|c|c|c|c|c|c|c|c|}
\hline $\begin{array}{l}\text { AR Coating } \\
\text { Material }\end{array}$ & ARC Structure & $\begin{array}{l}\text { Fabrication } \\
\text { Technology }\end{array}$ & Reflectance (\%) & $\begin{array}{c}\text { Transmittance } \\
\text { (\%) }\end{array}$ & $\begin{array}{l}\text { Wavelength } \\
(\mathrm{nm})\end{array}$ & Features & Research Potential & Reference \\
\hline Silica & $\begin{array}{l}\text { Moth-eye like } \\
\text { structure }\end{array}$ & $\begin{array}{l}\text { Sol-gel dip-coating } \\
\text { and electrostatic } \\
\text { self-assembly } \\
\text { technique }\end{array}$ & - & $8.21 \%$ increase & $400-800$ & $\begin{array}{l}\text { PCE is icreased from } \\
11.66 \% \text { to } 12.59 \% \text { for } \\
\text { CIGS device }\end{array}$ & $\begin{array}{l}\text { Stability, durability and } \\
\text { environmental effects } \\
\text { of/on the coating can be } \\
\text { analyzed }\end{array}$ & [120] \\
\hline $\begin{array}{c}\text { Mesoporous } \\
\text { silicon }+\mathrm{SiOx} \\
\text { layer }\end{array}$ & $\begin{array}{ll}\text { (i) } & \text { single layer Psi } \\
\text { (ii) } & \text { PSi layer + } \\
& \text { SiOx layer }\end{array}$ & $\begin{array}{l}\text { Plasma enhanced } \\
\text { chemical vapour } \\
\text { deposition }\end{array}$ & $\begin{array}{ll}\text { (i) } & 9 \\
\text { (ii) } & 3.8\end{array}$ & - & $400-1000$ & $\begin{array}{l}\text { Passivation property is } \\
\text { also improved }\end{array}$ & $\begin{array}{l}\text { Experimental analysis } \\
\text { of increase in PCE } \\
\text { using this coating }\end{array}$ & [83] \\
\hline $\begin{array}{l}\mathrm{SiO}_{2} \text { with boron } \\
\text { doped } \mathrm{Zinc} \text { oxide } \\
\text { (BZO) substrate }\end{array}$ & $\begin{array}{l}\mathrm{SiO}_{2} \mathrm{AR} \\
\text { coatings/glass/BZO }\end{array}$ & $\begin{array}{l}\text { Sol-gel dip coating } \\
\text { method }\end{array}$ & - & 93.4 & $400-1000$ & $\begin{array}{l}\text { The efficiency of the } \\
\text { amorphous thin film } \mathrm{Si} \\
\mathrm{PV} \text { cell enhanced from } \\
9.83 \% \text { to } 10.24 \%\end{array}$ & $\begin{array}{l}\text { Stability, reliabilty and } \\
\text { environmental effects } \\
\text { of/on the coating can be } \\
\text { analyzed }\end{array}$ & [104] \\
\hline Silicon nitride & $\begin{array}{l}\text { Single layer SiNx on } \\
\text { textured } \mathrm{Si} \text { wafer }\end{array}$ & Plasma deposition & 2.5 & 97 & $300-1000$ & $\begin{array}{l}\text { Good optical and } \\
\text { excellent passivation } \\
\text { properties }\end{array}$ & $\begin{array}{l}\text { Stability, durability and } \\
\text { environmental effects } \\
\text { of/on the coating can be } \\
\text { analysed }\end{array}$ & [122] \\
\hline Silicon nitride & $\begin{array}{l}\text { SiNx coating on } \\
\text { multicrystalline } \\
\text { silicon wafer }\end{array}$ & $\begin{array}{l}\text { Plasma texturization } \\
\text { and chemical etching }\end{array}$ & $<10$ & - & $350-800$ & $\begin{array}{l}\text { Perfomance } \\
\text { enhancement of mc-Si } \\
\text { solar cells }\end{array}$ & $\begin{array}{l}\text { A comparative study } \\
\text { with other ARC can be } \\
\text { made considering, } \\
\text { cost-effectiveness and } \\
\text { efficiency enhancement }\end{array}$ & [123] \\
\hline
\end{tabular}




\subsection{Metal-Based}

\subsubsection{Metal}

Metals as a thin film are widely used in optical fields $[124,125]$ and are extensively researched. It is generally known that metal surfaces are smooth and are subject to high reflectivity, rendering the transmission of propagated light, and a portion of it is ultimately absorbed. This problem can be overcome by texturing the metal surface with appropriate structures, which would result in decreased light reflection and increased light transmission into the solar cell [126-130]. For instance, Toma et al. [131] fabricated a light-absorbing and broadband antireflective nanostructured gold thin film with flexible properties. It is prepared by depositing gold vapor as a nano-cone array. By controlling the bead diameter and etching timing, the height and periodicity of the nanostructured cone array can be optimized. This optimized thin film exhibited an average reflectivity lesser than $1 \%$ over $450-950 \mathrm{~nm}$ spectral range with a wide-angle of incidence from $0-70^{\circ}$. The result obtained is due to a combined effect of plasmonic absorption and diffractive scattering loss. This method of fabrication can help in creating flexible nano-cone structured thin gold films. Apart from nano-cone structures, other nanostructures, such as nanopyramids, nano-cups, and nano-cavities, can also be obtained by plasma etching of the colloidal bilayers.

In recent years, metal nanofilms have evolved as a successful material to mitigate the reflection loss and to enhance the propagation of light into the material, and simultaneously, the film should absorb a minimum amount of light incident on it. Thus, while preparing the structures on metal films, it is necessary to choose the metal nanoparticles of such a shape and size that an optimized structure assists in maximizing the transmission of light.

\subsubsection{Metal Oxides}

Metal oxides possess an excellent antireflective property, and some of the commonly known metal oxides used as AR coatings are $\mathrm{TiO}_{2}, \mathrm{ZnO}, \mathrm{Al}_{2} \mathrm{O}_{3}$, Indium Tin Oxide (ITO), $\mathrm{Ta}_{2} \mathrm{O}_{5}$ and various nanostructured metal oxide films. Titanium Oxide $\left(\mathrm{TiO}_{2}\right)$ is widely preferred antireflection coating material in photovoltaics [132] due to its well matching refractive index, low deposition cost, durability, stability, hardness and possess excellent transmittance and mechanical resistance [133-135]. Regarding fabrication processes, $\mathrm{TiO}_{2}$ films are usually deposited by vacuum processes that include chemical vapor deposition [136-138], atomic layer deposition [139]. Under favorable fabrication conditions, a uniform film can be obtained, but these methods are expensive and are not appropriate for large-scale production, especially for the PV field. Methods such as sol-gel dip coatings [140,141], spray pyrolysis [142], hydrothermal process [143-145], and liquid phase deposition (LPD) [146] are also employed for coating $\mathrm{TiO}_{2}$ films on the substrate. Hocine et al. reported a $\mathrm{TiO}_{2}$ antireflection coating that is deposited using atmospheric pressure chemical vapor deposition (APCVD) method. Due to this, the reflectivity has brought down from $35 \%$ to $8.6 \%$, causing a rise in short circuit current density (Jsc) to $33.86 \mathrm{~mA} / \mathrm{cm}^{2}$ with a gain of $5.23 \mathrm{~mA} / \mathrm{cm}^{2}$ relative to the uncoated cell [147]. This study also shows that the fabrication of multi-crystalline Si cells using CVD as an efficient and cost-effective technique which together with AR coating, leads to an increase of $3 \%$ conversion efficiency compared to the reference cell. Super-hydrophilic coatings consisting of $\mathrm{TiO}_{2}$ is able to break down the organic contaminants when it interacts with light $[148,149]$. Adak et al., [150] developed a highly transparent, super hydrophilic, self-ordered, and photoactive $\mathrm{TiO}_{2}$ thin film coatings through a process of combined sol-gel and plasma-based approach. A block copolymer Pluronic F127 is used for such coatings, which play the role of structure-directing agent that helps in the creation of pores in $\mathrm{TiO}_{2}$ coating. Such a porous $\mathrm{TiO}_{2}$ thin film has a reduced RI of $\sim 1.31$ and possesses optical transparency as high as $95 \%$. The prepared film was observed to have robust mechanical characteristics with micro or nano hardness of 0.95-2.02 GPa and are also found to be super-hydrophilic having a water contact angle lesser than $5^{\circ}$, which claims to be a suitable candidate for PV application and other energy devices. 
In recent studies, it has been reported that better antireflection characteristics are obtained when $\mathrm{TiO}_{2}$ is combined with another material, such as with a layer of $\mathrm{SiO}_{2}$, which is discussed in the section of composite materials. $\mathrm{TiO}_{2}$ with $\mathrm{SiO}_{2}$ mono or multilayers can lower the effective $\mathrm{RI}$ of the substrate. Haider et al. [151] carried their work on $\mathrm{Ni}$-doped $\mathrm{TiO}_{2}$ thin films, which is coated by using pulsed laser deposition (PLD) technique. The $\mathrm{Ni}$ is doped in as 1,3 , and 5 weight $\%$ into $\mathrm{TiO}_{2}$ films, among which the maximum band gap is associated with a $5 \%$ doping level $(\mathrm{Eg}=3.82 \mathrm{eV})$. The $\left(\mathrm{TiO}_{2}\right)_{0.95} \mathrm{Ni}_{0.05}$ film exhibited the lowest reflectance of about $25.43 \%$ and a refractive index of 3.02. In certain studies, $\mathrm{TiO}_{2}$ is used as both antireflection coating films and as a passivation film. For example, Huang et al. [152] deposited titanium oxide as AR coatings using liquid phase deposition on Silicon nanowires solar cells. In this investigation, $\left(\mathrm{NH}_{4}\right)_{2} \mathrm{TiF}_{6}$ and $\mathrm{H}_{3} \mathrm{BO}_{3}$ solutions were employed for depositing $\mathrm{TiO}_{2}$. Under the condition of $0.5 \mathrm{M} \mathrm{H}_{3} \mathrm{BO}_{3}$ after annealing at $500{ }^{\circ} \mathrm{C}$ in the $\mathrm{N}_{2}$ atmosphere for $30 \mathrm{~min}$, the liquid phase deposited $\mathrm{TiO}_{2}$ films exhibited a reflectance of $3.6 \%$ and the effective minority carrier lifetime was $1.29 \mu$ s. The SEM images and reflectance spectra are shown in Figure 18. The $\mathrm{TiO}_{2}$ films fabricated in this case are used as antireflection coatings and passivation films. Visniakov et al. [153] tested high impulse power magnetron sputtering (HiPIMS) technology for depositing $\mathrm{TiO}_{2}$ coatings and investigated the antireflective properties of the film. They textured a pyramidal structure on silicon substrates before the deposition of $\mathrm{TiO}_{2}$. Then, different thicknesses of thin films were deposited on textured samples using both conventional Direct Current (DC) method, and HiPIMS method in the argon-oxygen atmosphere with a titanium target. The sample coated by the conventional DC method is taken as reference, and the coatings were observed using SEM, TEM, grazing index X-ray diffraction, ellipsometry, spectrophotometry techniques. On comparison, the HiPIMS deposited coatings exhibited lowest reflectance than that of DC deposited samples for the same thickness. In certain studies, double layer $\mathrm{TiO}_{2}$ coating is used for enhanced antireflection property. Richards [154] prepared a DLARC using only single $\mathrm{TiO}_{2}$ material. The optical parameters of titanium dioxide films were optimized by regulating the sintering and deposition conditions, which yielded coatings with refractive indices

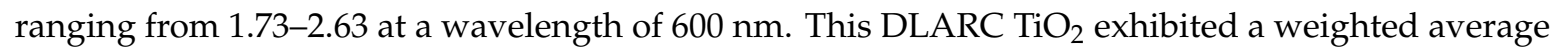
reflectance of about $6.5 \%$ and $7 \%$, in air and under glass individually. By coating on a silicon solar cell, the short-circuit current density is improved by $2.5 \mathrm{~mA} / \mathrm{cm}^{2}$ relative to $\mathrm{TiO}_{2}$ SLARC.

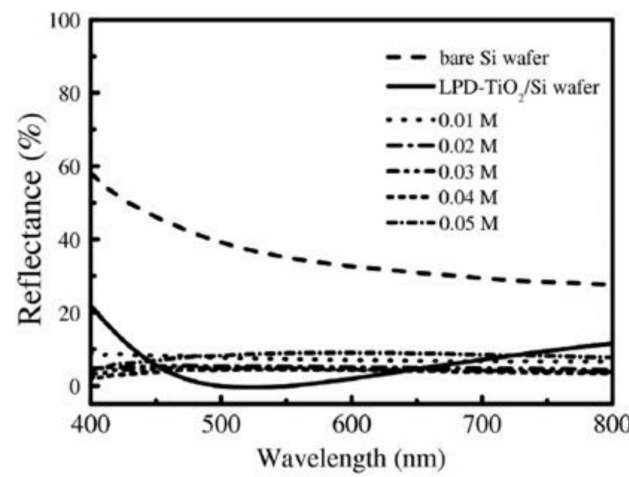

(a)

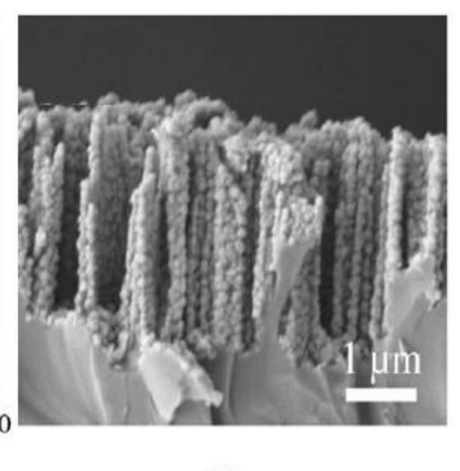

(b)

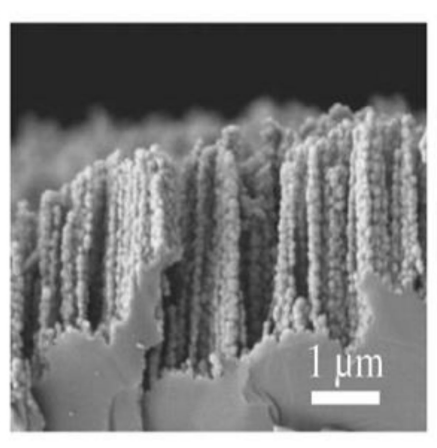

(c)

Figure 18. (a) The reflectance curve of $\mathrm{LPD}-\mathrm{TiO}_{2}$ thin film on $\mathrm{SiNWs}$ with different $\mathrm{H}_{3} \mathrm{BO}_{3}$ concentration in 400 to $800 \mathrm{~nm}$ wavelength range. (b) SEM cross-sectional images of LPD-TiO $2(0.3 \mathrm{M}) / \mathrm{SiNWs} / \mathrm{Si}$, (c) LPD-TiO2 (0.4 M)/SiNWs/Si. Reprinted with permission [152]; 2017, Elsevier.

Over a decade, AR coatings based on Zinc oxides $(\mathrm{ZnO})$ nanostructures such as nanorod, nanowires, nanotube, and nanoneedle have attracted massive attention for research in optoelectronic and nanodevices due to their excellent optical performance, broad bandgap [155-161]. Generally, zinc oxide nanostructured arrays were created by electron beam evaporation [162], wet chemical deposition [163], chemical vapor deposition [164]. Also, low-cost methods of fabrication include the sol-gel method [165] and hydrothermal synthesis [166,167]. For instance, Nowak et al. constructed 
the arrays of Zinc oxide nanorods on Al-doped $\mathrm{ZnO}$ seed layers using an electrochemical deposition method in which the size of the nanorod arrays can be easily controlled [168]. It exhibited a reflectivity of about $6.1 \%$ in $340-760 \mathrm{~nm}$ wavelength range with a $400 \mathrm{~nm}$ thick seed layer. These enhanced antireflection properties contributed in improving the PCE of silicon solar cells. Chung et al. [169] fabricated $\mathrm{ZnO}$ nanostructures on silicon wafers by utilizing the hydrothermal technique. In this technique, the zinc acetate thin films are employed as a seed layer, and the density of $\mathrm{ZnO}$ nanorods can be changed by controlling the spin-coating speed and annealing time. The results showed that the nanorods reduced the Fresnel reflection loss owing to the gradient refractive index obtained in the structure, and the total reflectance was about $11 \%$. In contrast, it was also observed that the nanorod morphology changes from wire-like geometry to tower-like geometry as the ascorbic acid concentration is increased. Another study focusing on GaAs p-n junction solar cell was researched by Makableh et al. [170] with $\mathrm{ZnO}$ antireflection coating of $110 \mathrm{~nm}$ thickness formed by sol-gel technique, and the refractive index and the reflectance was measured using ellipsometry. The spectral response showed an average refractive index of 1.65 in the wavelength span of 400-900 nm, and the reflectance is reduced from $33 \%$ to a lower value of about $3 \%$ at $650 \mathrm{~nm}$, whereas the transmission at $980 \mathrm{~nm}$ was increased from $45 \%$ to $60 \%$. Further, the power conversion efficiency and quantum efficiency were enhanced in the order of $32 \%$ and $51 \%$, respectively.

$\mathrm{Qu}$ et al. [171], produced $\mathrm{ZnO}$ nanorod arrays (NRAs) through a cost-effective chemical bath deposition method and analyzed their AR property on mc-Si solar cells. The structure and the morphology were analyzed and studied by SEM, TEM, and X-ray diffractometer. From the analysis, it is seen that the ZnO NRA features a wurtzite structure having a diameter of around $40-50 \mathrm{~nm}$. The comparison is made between $\mathrm{ZnO}$ thin film-coated, $\mathrm{ZnO}$ nanorod array coated, and uncoated solar cells. The average reflectance calculated for the fabricated three solar cells was $18.1 \%, 15.9 \%, 41.6 \%$, respectively. The steps involved in the fabrication, schematic structure of three solar cells, and the reflectance spectra are shown in Figure 19. The PCE of the ZnO nanorod array coated solar cell was found to be $6.61 \%$ rather than $2.27 \%$ for uncoated solar cell. Further, it is also observed that ZnO NRA proves to be much more effective as an antireflective coating than $\mathrm{ZnO}$ thin film.

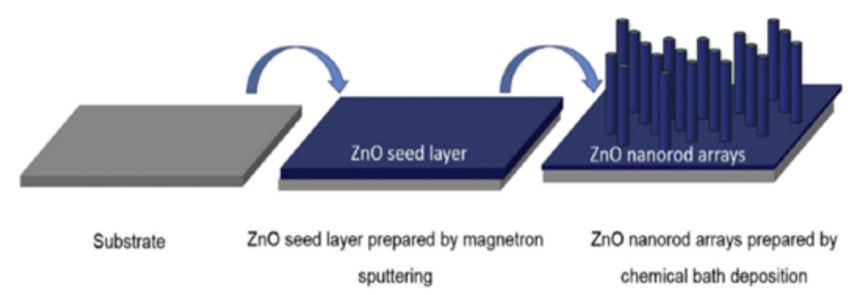

(a)

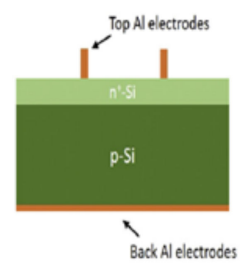

(a) First type of solar cells

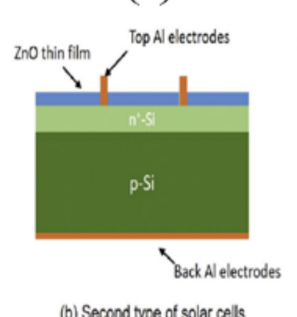

(b)

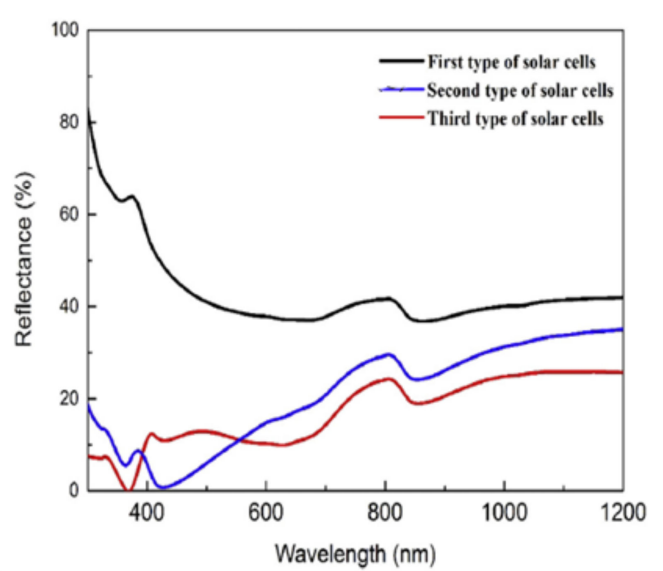

(c)

Figure 19. (a) Steps involved in the fabrication of $\mathrm{ZnO}$ nanorod arrays. (b) Schematic structures of fabricated three types of solar cells. (c) Variation of reflectance for the fabricated solar cells with respect to wavelength. Reprinted with permission [171]; 2017, Elsevier.

Lin et al. [172], researched on antireflection coating structure with syringe-shaped $\mathrm{ZnO}$ nanorod arrays, which were prepared by a two-step aqueous solution method. The cross-section SEM image and the reflectance spectra are shown in Figure 20. The surface reflectivity was reduced to below 5\% 
over broad wavelength range on multi-crystalline Si solar cells. Also, the short-circuit current density and the PCE was improved by $\sim 37 \%$ and $\sim 41 \%$ relative to that of the bare surface. This was primarily due to the ultra-sharp tips on the top of nanorods, which results in a progressive rise in RI from the air to the nanorods bottom. Fernandez et al. [173] constructed a novel $\mathrm{ZnO}: \mathrm{Al}$ thin film and investigates the optical properties of the film with the thickness varying from 80 to $110 \mathrm{~nm}$. The film is coated on a polished silicon wafer using RF magnetron sputtering, and the texturization of the surface is carried out by the wet etching process based on $\mathrm{NH}_{4} \mathrm{Cl}$. The optimized textured films exhibited a weighted reflectance below $15 \%$.

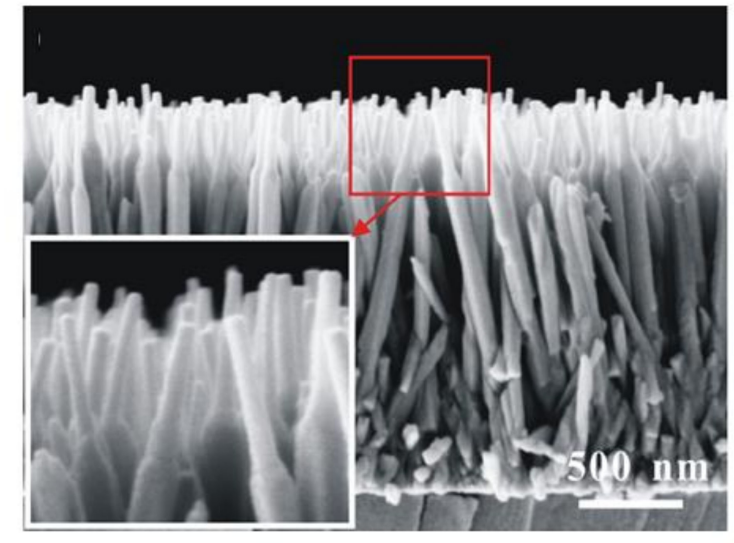

(a)

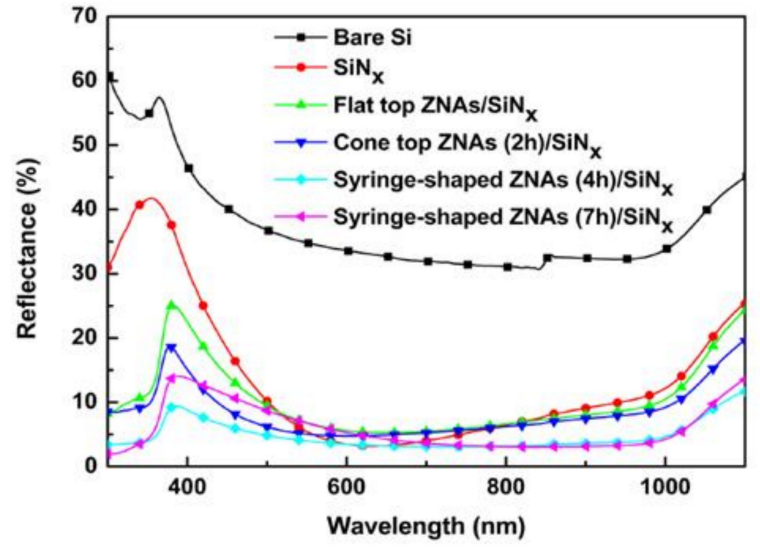

(b)

Figure 20. (a) Cross-section SEM image of the syringe-shaped ZnO nanorod arrays. (b) Comparison of reflectance of mc-Si PV cells with various surface conditions. Reprinted with permission [172]; 2018, Elsevier.

Indium tin oxide (ITO) is widely preferred material for the construction of transparent conductive electrodes owing to its superior conductivity and transmittance. For instance, Yun et al. constructed an ITO nano-lens arrays using UV nano-imprint and etching techniques on Si substrate [174]. The reflectance of the fabricated nano-lens arrays with a thickness of $80 \mathrm{~nm}$ was $4.7 \%$ in the wavelength between 400 and $1100 \mathrm{~nm}$ and exhibited almost nil reflection for a wide angle of incidence. Also, Ham et al. prepared a transparent ITO coating with nano-branched structures via electron beam deposition method on the front surface of the glass, which showed an average transmittance of about $92 \%$ with the thickness ranging from 550 to $820 \mathrm{~nm}$ in the $500-800 \mathrm{~nm}$ wavelength range [175]. Tien et al. [176] fabricated a double layer ARC by using Indium tin oxide. The high refractive index bottom ITO layer is constructed by a long-throw RF magnetron sputtering method at room temperature, and the low refractive index top ITO layer is constructed by supercritical $\mathrm{CO}_{2}\left(\mathrm{SCCO}_{2}\right)$ treatment at $60{ }^{\circ} \mathrm{C}$ on gel-coated ITO films. The RI of the coatings was controlled by varying the operating pressure of sputtering and $\mathrm{SCCO}_{2}$ treatment and sputtering power. The average transmittance and reflectance of DARC ITO thin films were found to be $86.2 \%$ and $4.3 \%$, respectively.

In the 20th century, researches were also focused on $\mathrm{Ta}_{2} \mathrm{O}_{5}$ as an antireflection coating film. For example, Rubio et al. [177] used $\mathrm{Ta}_{2} \mathrm{O}_{5}$ thin films as an antireflection coating on monocrystalline silicon cells, which is deposited by magnetron reactive sputtering. By doing so, the reflectance of the $\mathrm{Si}$ surface is reduced from 30\% to about 3\% approximately. On the other hand, in another study [178], the refractive index was brought close to 2.0 in the visible region, and the PCE of the cell was enhanced from $9.5 \%$ to $12.9 \%$.

\subsubsection{Metal Fluorides}

When considering metal fluorides, magnesium fluoride $\left(\mathrm{MgF}_{2}\right)$ prevails as prominent antireflective material. $\mathrm{MgF}_{2}$ is widely used in antireflection coatings because of their lower refractive index (lower 
than glass), high transparency and is generally added for composite AR coatings $[179,180]$. Also, various kinds of morphologies of $\mathrm{MgF}_{2}$ particles such as nanorods, hollow spherical particles, cube, and platelets, induce properties based on their structure [181-184] and are gaining more attention in research. Reddy et al. used hollow magnesium fluoride nanoparticles (Figure 21a) to develop a high-performance broadband AR coating [185]. It exhibited an average transmittance (Figure 21b) of $98.3 \%$ in the $400-800 \mathrm{~nm}$ wavelength range and $96.2 \%$ in solar spectral range (300-1500 nm). Such high transmittance is obtained as a result of the facile formation-deformation-reformation synthesis route, and a high-performance ARC with a low RI, high durability in the economic range is obtained. Another study by Karthik et al. synthesized high-performance ink-bottle mesoporous $\mathrm{MgF}_{2}$ nanoparticles [186]. A deformation-formation route via lyothermal synthesis is utilized for preparing the nanoparticles from coarse commercial $\mathrm{MgF}_{2}$ hydrate powder. By using the dip-coating method, a single layer of ARC is obtained after the dispersion of nanoparticles into a suitable solvent. The developed AR coating achieved a transmittance of nearly $100 \%$ in $615-660 \mathrm{~nm}$ wavelength range and exhibited an average transmittance of $99 \%$ and $97 \%$ in the wavelength range of $400-800 \mathrm{~nm}$ and active solar range (300-1500 nm), respectively. Moreover, the usage of such AR coatings on solar cell glass increased the efficiency by $6 \%$ for crystalline silicon solar cells.

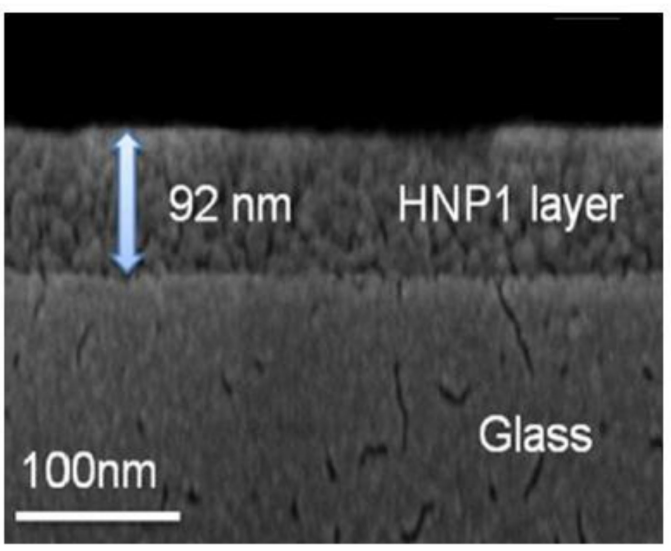

(a)

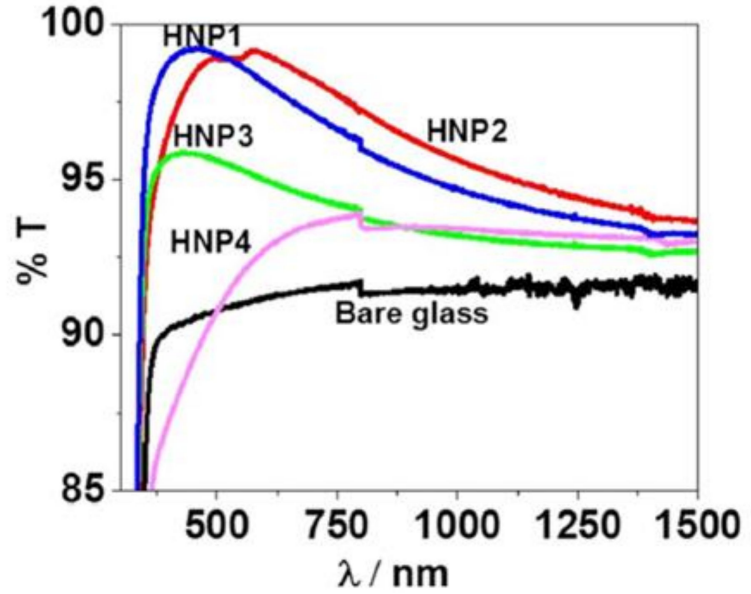

(b)

Figure 21. (a) FIB cross-sectional image of $\mathrm{ARC}$ consisting of hollow $\mathrm{MgF}_{2}$ nanoparticles (HNP-1 layer). (b) Transmittance spectra of AR films comprised of different hollow nanoparticles. Reprinted with permission [185]; 2018, Elsevier.

Pendse et al. [187] reported a hydrophobic modification of high-performance broadband antireflection coating with mesoporous $\mathrm{MgF}_{2}$ nanoparticles. The prepared $\mathrm{MgF}_{2}$ film is hydrophilic with a WCA of $27^{\circ}$ and possesses high transmission higher than $99 \%$ in the visible range and is greater than $97 \%$ in active solar range. The film is modified into the hydrophobic coating with the help of flurosilane carrying silica sol using a dip-coating technique, which significantly widens the WCA to $130^{\circ}$ without any modification in transmission characteristics of the film. This modified layer exhibits a transmission of $98.8 \%$ in the visible range $(400-800 \mathrm{~nm})$ and $97.03 \%$ in active solar spectral range (300-1500 nm) with hydrophobic nature. Also, this layer is reported to be environmentally stable and is suitable for PV and optical applications. A summary of metal-based antireflection coatings is provided in Table 4. 
Table 4. Metal based antireflection coatings.

\begin{tabular}{|c|c|c|c|c|c|c|c|c|}
\hline $\begin{array}{l}\text { AR Coating } \\
\text { Material }\end{array}$ & ARC Structure & $\begin{array}{l}\text { Fabrication } \\
\text { Technology }\end{array}$ & Reflectance (\%) & $\begin{array}{c}\text { Transmittance } \\
(\%)\end{array}$ & $\begin{array}{l}\text { Wavelength } \\
\text { Range (nm) }\end{array}$ & Features & Research Potential & Reference \\
\hline $\mathrm{Au}$ & $\begin{array}{l}\text { Nanocone } \\
\text { arrays }\end{array}$ & $\begin{array}{l}\text { Gold vapor } \\
\text { deposition }\end{array}$ & $<1$ & - & $450-950$ & $\begin{array}{l}\text { Broadband antireflective and } \\
\text { light-absorbing properties }\end{array}$ & $\begin{array}{l}\text { Effect of this coating on } \\
\text { various solar cells to find } \\
\text { its suitable application }\end{array}$ & [131] \\
\hline $\mathrm{TiO}_{2}$ & Thin film & $\begin{array}{l}\text { Atmospheric pressure } \\
\text { chemical vapor } \\
\text { deposition }\end{array}$ & 8.61 & - & $300-1150$ & $\begin{array}{l}\text { Simple, inexpensive } \\
\text { methodology and attains a } \\
+3 \% \text { gain in PCE relative to the } \\
\text { reference cell }\end{array}$ & $\begin{array}{l}\text { Stability, reliabilty and } \\
\text { environmental effects } \\
\text { of/on the coating can be } \\
\text { analysed }\end{array}$ & [147] \\
\hline $\mathrm{TiO}_{2}$ & Porous film & $\begin{array}{l}\text { Sol-gel based } \\
\text { self-assembly and } \\
\text { plasma-based } \\
\text { approach }\end{array}$ & - & 95 & $400-900$ & $\begin{array}{l}\text { Usage of a novel fabrication } \\
\text { method involving a low-cost } \\
\text { block copolymer }\end{array}$ & $\begin{array}{l}\text { Experimental analysis of } \\
\text { increase in PCE using this } \\
\text { coating }\end{array}$ & [150] \\
\hline Ni-doped $\mathrm{TiO}_{2}$ & Thin film & $\begin{array}{l}\text { Pulsed Laser } \\
\text { Deposition }\end{array}$ & - & 60 & $300-1100$ & $\begin{array}{l}\text { Reflectance decreased with } \\
\text { increasing Ni concentrations } \\
\text { significantly }\end{array}$ & $\begin{array}{l}\text { Research to improve } \\
\text { transmittance further can } \\
\text { be considered }\end{array}$ & [151] \\
\hline $\mathrm{TiO}_{2}$ & $\mathrm{TiO}_{2}$ thin films & $\begin{array}{l}\text { Liquid phase } \\
\text { deposition }\end{array}$ & 3.6 & - & $400-800$ & $\begin{array}{l}\text { Excellent compatibility, } \\
\text { uniformity, large-scale } \\
\text { production blended with } \\
\text { cost-effectiveness. }\end{array}$ & $\begin{array}{l}\text { Experimental analysis of } \\
\text { increase in PCE using this } \\
\text { coating }\end{array}$ & [152] \\
\hline $\mathrm{TiO}_{2}$ & $\begin{array}{l}\mathrm{TiO}_{2} \text { thin films } \\
\text { deposited on } \\
\text { textured } \mathrm{Si} \\
\text { substrate }\end{array}$ & $\begin{array}{l}\text { High impulse power } \\
\text { magnetron sputtering }\end{array}$ & $<3$ & - & $400-1100$ & $\begin{array}{l}\text { HiPIMS deposited films show } \\
\text { the lowest reflectance in } \\
\text { comparison to the DC } \\
\text { deposited samples of the same } \\
\text { thickness }\end{array}$ & $\begin{array}{l}\text { Effect of this coating on } \\
\text { various solar cells to find } \\
\text { its suitable application }\end{array}$ & [153] \\
\hline $\mathrm{TiO}_{2}$ & $\begin{array}{l}\text { Double layer } \\
\mathrm{TiO}_{2} \text { film }\end{array}$ & $\begin{array}{l}\text { Atmospheric pressure } \\
\text { chemical vapor } \\
\text { deposition }\end{array}$ & 6.5 & - & $350-1150$ & $\begin{array}{l}2.5 \mathrm{~mA} / \mathrm{cm}^{2} \text { improvement in } \\
\text { the short-circuit current density }\end{array}$ & $\begin{array}{l}\text { Experimental analysis of } \\
\text { the increase in PCE using } \\
\text { this coating }\end{array}$ & [154] \\
\hline
\end{tabular}


Table 4. Cont

\begin{tabular}{|c|c|c|c|c|c|c|c|c|}
\hline $\begin{array}{l}\text { AR Coating } \\
\text { Material }\end{array}$ & ARC Structure & $\begin{array}{l}\text { Fabrication } \\
\text { Technology }\end{array}$ & Reflectance (\%) & $\begin{array}{c}\text { Transmittance } \\
\text { (\%) }\end{array}$ & $\begin{array}{l}\text { Wavelength } \\
\text { Range (nm) }\end{array}$ & Features & Research Potential & Reference \\
\hline $\mathrm{ZnO}$ & Nanorod array & $\begin{array}{l}\text { Electrochemical } \\
\text { deposition method }\end{array}$ & 6.1 & - & $340-760$ & $\begin{array}{l}\text { The size of the nanorod arrays } \\
\text { can be easily controlled }\end{array}$ & $\begin{array}{l}\text { Reflectance for increased } \\
\text { bandwidth can be } \\
\text { analyzed combined with } \\
\text { PCE analysis }\end{array}$ & [168] \\
\hline $\mathrm{ZnO}$ & Nanorods & $\begin{array}{l}\text { Hydrothermal } \\
\text { method }\end{array}$ & 14.8 & - & $400-800$ & $\begin{array}{l}\text { Different morphologies of } \mathrm{ZnO} \\
\text { is obtained and observed for } \\
\text { reflectance }\end{array}$ & $\begin{array}{l}\text { Research to reduce } \\
\text { reflectance further can be } \\
\text { considered }\end{array}$ & [169] \\
\hline $\mathrm{ZnO}$ & Thin film & Sol-gel method & 3 & - & 650 & $\begin{array}{l}\text { Enhancement in the PCE of } \\
\text { GaAs p-n junction PV cell by } \\
30 \%\end{array}$ & $\begin{array}{l}\text { Reflectance for increased } \\
\text { bandwidth can be } \\
\text { analyzed }\end{array}$ & [170] \\
\hline $\mathrm{ZnO}$ & Nanorod array & $\begin{array}{l}\text { Chemical bath } \\
\text { deposition }\end{array}$ & 15.9 & - & $300-1200$ & $\begin{array}{l}\text { PCE increases from } 2.27 \% \text { to } \\
6.61 \% \text { in polycrystalline } \mathrm{Si} \\
\text { solar cells }\end{array}$ & $\begin{array}{l}\text { Research to reduce } \\
\text { reflectance further can be } \\
\text { considered }\end{array}$ & [171] \\
\hline $\mathrm{ZnO}$ & $\begin{array}{l}\text { Syringe shaped } \\
\text { Nanorod }\end{array}$ & $\begin{array}{l}\text { Two-step aqueous } \\
\text { solution technique }\end{array}$ & $<5$ & - & $300-1100$ & $\begin{array}{l}\text { Improvement of short-circuit } \\
\text { current density and PCE by } \\
\sim 37 \% \text { and } \sim 41 \% \text {, respectively }\end{array}$ & $\begin{array}{l}\text { Effect of this coating on } \\
\text { various solar cells to find } \\
\text { its suitable application }\end{array}$ & [172] \\
\hline $\mathrm{ZnO}$ & $\begin{array}{l}\text { Moth eye } \\
\text { structure }\end{array}$ & $\begin{array}{l}\text { Aqueous solution } \\
\text { method }\end{array}$ & 1.46 & - & $200-800$ & $\begin{array}{l}\text { The PCE of the PV cell } \\
\text { enhanced from } 10 \% \text { to } 11.5 \%\end{array}$ & $\begin{array}{l}\text { Stability, reliability and } \\
\text { environmental effects } \\
\text { of/on the coating can be } \\
\text { analyzed }\end{array}$ & [188] \\
\hline $\mathrm{ZnO}: \mathrm{Al}$ & Thin film & $\begin{array}{l}\text { Radio frequency } \\
\text { magnetron sputtering }\end{array}$ & $<15$ & - & $300-1050$ & $\begin{array}{l}\text { Increment achieved in the } \\
\text { roughness of the film and } \\
\text { decrease of its sheet resistance } \\
\text { helps to enhance the efficiency } \\
\text { of the devices }\end{array}$ & $\begin{array}{l}\text { Experimental analysis of } \\
\text { the increase in PCE using } \\
\text { this coating }\end{array}$ & [173] \\
\hline ITO & Nano-lens array & $\begin{array}{l}\text { UV nano-imprinting } \\
\text { and oxygen etching }\end{array}$ & 4.7 & - & $400-1100$ & $\begin{array}{l}\text { Exhibited near-zero reflectance } \\
\text { in wide incident angles }\end{array}$ & $\begin{array}{l}\text { Experimental analysis of } \\
\text { the increase in PCE using } \\
\text { this coating }\end{array}$ & [174] \\
\hline ITO & $\begin{array}{l}\text { Nano-branched } \\
\text { stuctures }\end{array}$ & $\begin{array}{l}\text { Electron beam } \\
\text { deposition method }\end{array}$ & - & 92 & $500-800$ & $\begin{array}{l}\text { High transmittance and } \\
\text { conductive material }\end{array}$ & $\begin{array}{l}\text { Transmission can be } \\
\text { analyzed and improved } \\
\text { for broadband } \\
\text { wavelength }\end{array}$ & [175] \\
\hline
\end{tabular}


Table 4. Cont.

\begin{tabular}{|c|c|c|c|c|c|c|c|c|}
\hline $\begin{array}{l}\text { AR Coating } \\
\text { Material }\end{array}$ & ARC Structure & $\begin{array}{l}\text { Fabrication } \\
\text { Technology }\end{array}$ & Reflectance (\%) & $\begin{array}{c}\text { Transmittance } \\
\text { (\%) }\end{array}$ & $\begin{array}{l}\text { Wavelength } \\
\text { Range (nm) }\end{array}$ & Features & Research Potential & Reference \\
\hline ITO & $\begin{array}{l}\text { Double layer } \\
\text { ITO film }\end{array}$ & $\begin{array}{l}\text { Long throw radio } \\
\text { frequency magnetron } \\
\text { sputtering technique } \\
+ \text { supercritical } \mathrm{CO}_{2} \\
\text { treatment }\end{array}$ & 4.3 & 86.2 & $400-1000$ & $\begin{array}{l}\text { The low optical reflectance and } \\
\text { excellent electrical conductance } \\
\text { make it suitable for Si-based } \\
\text { solar cell applications }\end{array}$ & $\begin{array}{l}\text { Research to improve } \\
\text { transmittance further can } \\
\text { be considered, and } \\
\text { together with PCE } \\
\text { analysis can be } \\
\text { considered }\end{array}$ & [176] \\
\hline $\mathrm{MgF}_{2}$ & $\begin{array}{l}\text { Hollow } \\
\text { nanoparticles }\end{array}$ & $\begin{array}{l}\text { Formation-deformation-re } \\
\text { approach }\end{array}$ & reformation & 96.2 & $300-1500$ & $\begin{array}{l}\text { High-performance AR coating } \\
\text { with a low index of refraction, } \\
\text { high durability, and } \\
\text { economical coating }\end{array}$ & $\begin{array}{l}\text { Effect of this coating on } \\
\text { various solar cells to find } \\
\text { its suitable application }\end{array}$ & [185] \\
\hline $\mathrm{MgF}_{2}$ & $\begin{array}{l}\text { Mesoporous } \\
\mathrm{MgF}_{2} \\
\text { nanoparticles }\end{array}$ & $\begin{array}{l}\text { Deformation-reformation } \\
\text { approach }\end{array}$ & - & 97 & $300-1500$ & $\begin{array}{l}\text { Broadband } \mathrm{ARC} \text { is obtained } \\
\text { with a simple method using } \\
\text { ink-bottle } \mathrm{MgF}_{2} \text {. }\end{array}$ & $\begin{array}{l}\text { Effect of this coating on } \\
\text { various solar cells to find } \\
\text { its suitable application }\end{array}$ & [186] \\
\hline $\mathrm{MgF}_{2}$ & $\begin{array}{l}\text { Mesoporous } \\
\mathrm{MgF}_{2} \\
\text { nanoparticles }\end{array}$ & $\begin{array}{l}\text { Lyothermal and Dip } \\
\text { coating process }\end{array}$ & - & 97.03 & $300-1500$ & $\begin{array}{l}\text { The hydrophilic surface of } \\
\mathrm{MgF}_{2} \text { AR films is advanced to } \\
\text { hydrophobicity }\end{array}$ & $\begin{array}{l}\text { Experimental analysis of } \\
\text { the increase in PCE using } \\
\text { this coating }\end{array}$ & [187] \\
\hline Barium titanate & Thin film & $\begin{array}{l}\text { Radio frequency } \\
\text { magnetron sputtering }\end{array}$ & $50 \%$ reduction & - & $250-1100$ & Usage of barium titanate & $\begin{array}{l}\text { Stability, reliability and } \\
\text { environmental effects } \\
\text { of/on the coating can be } \\
\text { analyzed }\end{array}$ & [189] \\
\hline
\end{tabular}




\subsection{Polymer-Based}

In this decade, the usage of polymer films as ARCs have been consistently increasing for numerous state-of-art optical applications to minimize the reflection loss between air and the substrate [190-192]. The characteristics of the polymers such as high mechanical strength, easy and quick fabrication, good optical properties, lightweight, chemical and thermal resistance, and mainly its cost-effective production makes polymer to have a superior advantage over other materials. Nanopatterned antireflective polymer films, namely polystyrene (PS) [6], poly(methyl methacrylate) (PMMA) [193], poly(dimethyl siloxane) (PDMS) [194] and poly (ethylene terephthalate) (PET) [195], polyimide (PI) [196], and ethoxylated trimethylolpropane tri acrylate (ETPTA) [23] have been reported to enhance the transmission of light. Moreover, the nano-polymer films can be easily prepared by many nanopatterning methodologies, which include plasma etching [195], soft imprint lithography [94], and microinjection compression molding [197]. Antireflective polymer films with the sub-wavelength structure are the new area of research under exploration.

\subsubsection{Polystyrene (PS)}

Polystyrene has an index of refraction of 1.6 and a transmittance of up to $88-92 \%$. The material possesses good thermal stability, fluidity, which enables it suitable for the molding process, especially injection molding. Owing to its stability, cost-effective and fast synthesis, the self-assembly polystyrene spheres are commonly used as a template for etching colloidal single layer to create patterns on various substrates [198-201]. For instance, Li et al. reported antireflective polystyrene film textured with a conical micropore structure and coated on both surfaces of the silicon substrate. The textured polystyrene film showed a transmittance of nearly $75 \%$ at a bandwidth of $0.1-1.5 \mathrm{THz}$ [202]. The performance of such material can still be improved by adjusting the structure parameter, mold parameters, and material. Recently, Xie et al. produced biomimetic PS film consisting of nanopillar arrays exhibiting antireflective properties whose structure is inspired by the cicada wings nanostructure [197]. They replicated the nanostructures on PS surface using microinjection compression molding in which the nickel mold is used as an inverted template. The nano-textured PS surface achieved a reflectance of nearly $4 \%$ in the $400-1000 \mathrm{~nm}$ span of the spectrum and also exhibited a water contact angle of $143^{\circ} \pm 2^{\circ}$. The same group also constructed a PS film having pyramidal arrays using the same fabrication methodology mentioned above with an inverted pyramid-structured nickel mold as the template [6]. This film exhibited a reflectance of $\sim 5 \%$ and a transmittance of about $93 \%$ in the $400-900 \mathrm{~nm}$ wavelength range. The SEM images, reflectance spectra, and the photograph are represented in Figure 22a-d, respectively. 


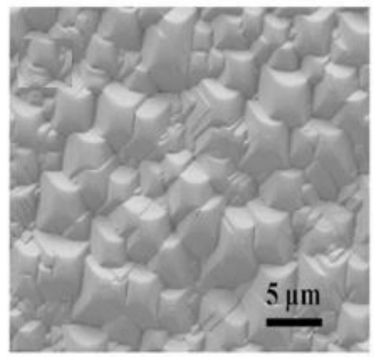

(a)

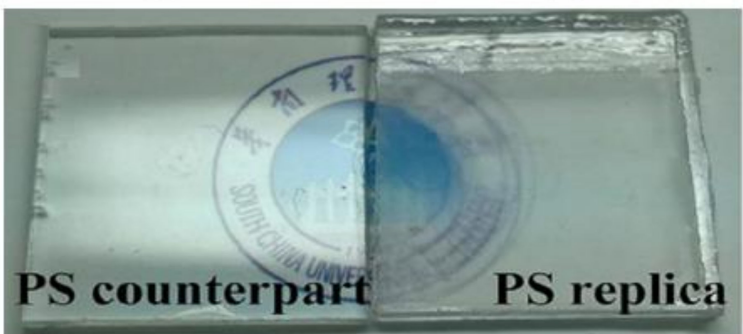

(d)

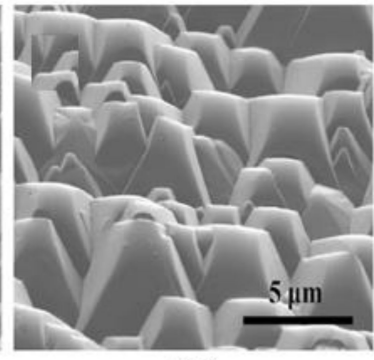

(b)

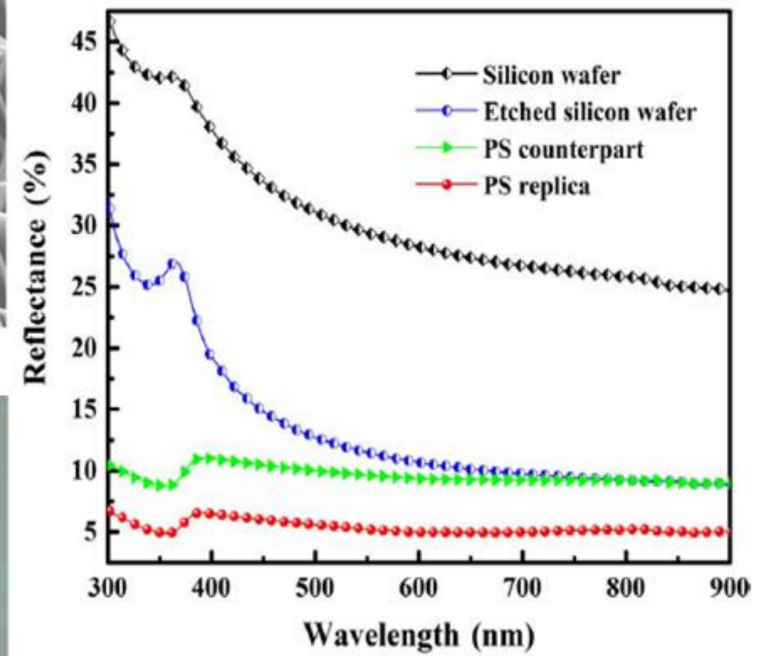

(c)

Figure 22. (a) Top and (b) tilted views of PS replica molded by micro-ICM (SEM images). (c) Comparison of reflectance spectra of silicon wafer, etched silicon wafer, PS counterpart, and PS replica. (d) Photograph of PS replica and PS counterpart exposed to white fluorescent light. Reprinted with permission [6]; 2017, Elsevier.

\subsubsection{Poly (Methyl Methacrylate) (PMMA)}

PMMA has a refractive index of 1.49 with outstanding optical transparency in a broad wavelength range, including near-IR and visible regions, which is a unique property of PMMA. This polymer also has high toughness, mechanical strength, and chemical resistance, as well as thermal shock resistance, but it has low fluidity, surface hardness, and poor scratch resistance. PMMA as AR films usually possess nanopatterns that include nanopillar, nano-dome, nano-needle, nano-cone, moth-eye structures which can be fabricated by nano-print lithography, a combination of colloidal lithography and cast molding followed by reversal nanoimprint lithography [36,203], RIE coupled with nanoimprint, and block copolymer micelle lithography [204]. For example, an antireflection coating of a parabolic shape made of PMMA possesses nano-cone arrays having a base diameter of $85 \mathrm{~nm}$ and a height of $180 \mathrm{~nm}$, which were fabricated by vacuum-assisted surface wetting methodology employing an anodic aluminum oxide as a template with nanopore-pattern [193]. In the $400-800 \mathrm{~nm}$ wavelength range, the coating demonstrated an average transmittance and reflectance of $99.4 \%$ and $0.64 \%$, respectively. Kim et al. developed an antireflective PMMA film with nanopillar structure, which is produced by using thermal nanoimprinting. In this method, laser lithography and dry etching are employed for preparing nanostructured silicon master imprint [5]. Such nanopatterns demonstrated reflectance lesser than $0.5 \%$ in the visible wavelength range. In general, nanoimprint methodology is the commonly used fabrication method to architect diverse nanostructures on the PMMA surface to achieve a high antireflective effect owing to its simple, large-scale, and cost-effective production. Hence, the master molds dimension and shape must be sculpted perfectly by using advanced technologies. However, by doing so, the overall cost might be expensive.

\subsubsection{Poly (Dimethylsiloxane) (PDMS)}

The PDMS is often employed as an antireflective encapsulation film to preserve the material and optical devices from mechanical damage, rust, dust, and other contaminations [36]. These properties are mainly due to the material characteristics such as hardness, strong adhesion, thermal stability, oxidation resistance, formability, flexibility, and also good transparency. It has a low refractive index of about 1.4-1.43, a closer value to that of glass [3,194]. Many studies have reported 
PDMS films with nanostructures such as nano-cones, wrinkle structure, hemispheres, nanopillar, and moth-eye structures were used as AR coatings. While considering preparation techniques, soft imprint lithography [18], molding process [205], self-assembly technique [206], biological template, and plasma treatment are employed in fabricating PMMA [207-209]. For instance, Galeotti et al. developed an antireflective PDMS film having a hemispherical nano-dome structure whose average diameter is less than $300 \mathrm{~nm}$ [206]. For the PDMS film fabricated, the maximum transmittance of about $95 \%$ is obtained, and reflectivity value was lesser than $2 \%$ relative to the uncoated sample in 400-900 nm wavelength range. Lim et al. fabricated inversely tapered nanoholes (NHs) structures on the surface of PDMS film using soft lithography, which employs conical nanopillars structured Si molds as a template [94]. The film is deposited on the outer surface of the glass coated with FTO. The optimized PDMS film has NHs structures with a height of $320 \mathrm{~nm}$ and exhibited a reduced reflectance of about $\sim 7.1 \%$ at normal incidence in the span of 350-800 nm wavelength. When this film is employed on DSSC, the PCE was increased from $7.15 \%$ to $7.56 \%$. Dudem et al. developed a PDMS coating having nano-nipple structures via soft imprint lithography technique on inverted micro-pyramidal arrays [210]. The nano-structured PDMS coating deposited on ITO/PET demonstrated a transmittance and reflectance of nearly $92.1 \%$ and $\sim 9.5 \%$, respectively. The same research team developed subwavelength structured architecture PDMS (SWAPDMS) as an antireflection film by the above-mentioned method on a glass substrate via Anodized Aluminum Oxide (AAO) molds. It exhibited a flux-weighted transmittance of about $\sim 95.4 \%$ and also a low flux-weighted reflectance value of nearly $4.68 \%$ in $350-800 \mathrm{~nm}$ wavelength region. Zhang et al. designed a low-cost ARC using PDMS having a wrinkled surface in which the relative PCE of the coated cell on average is enhanced approximately by $13.6 \%$ [211].

\subsubsection{Poly (Ethylene Terephthalate) (PET)}

The PET is a transparent thermoplastic polymer which has an index of refraction of 1.58. The advantages of this material include high transparency, good corrosion resistance, ultraviolet blocking tendency, low-temperature resistance, and suitable mechanical property. A nano-cone array embedded in PET film prepared by the RIE method is used as an AR coating that reported to have self-cleaning properties [190]. This film demonstrated outstanding optical performance in 300-900 nm wavelength range, indicating a transmittance of $\sim 97 \%$ and reflectance of $\sim 0.5 \%$ with superhydrophobic properties. The optical effects rely on the shape and size of nano-cone patterns and duration of RIE. Kumar et al. developed a nano-porous AR-pattern by implementing a single-step plasma etching technique on both sides of the PET surface [195]. The FESEM micrographs, transmittance, and reflectance spectra are represented in Figure 23. 


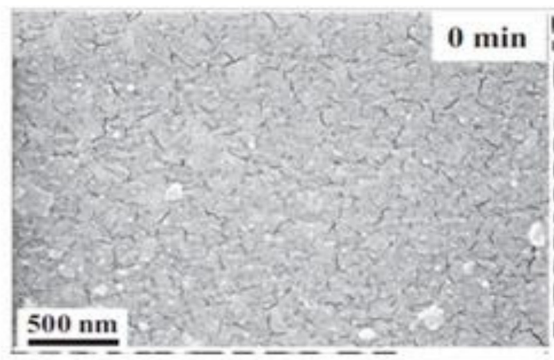

(a)

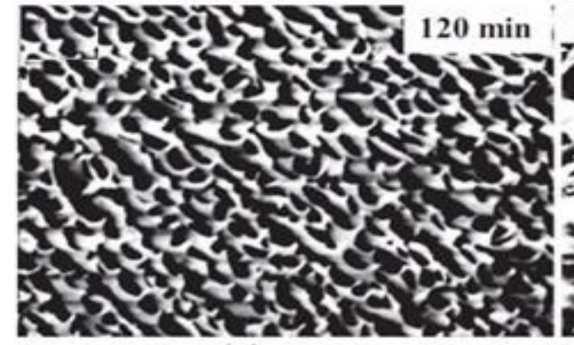

(c)

(i)

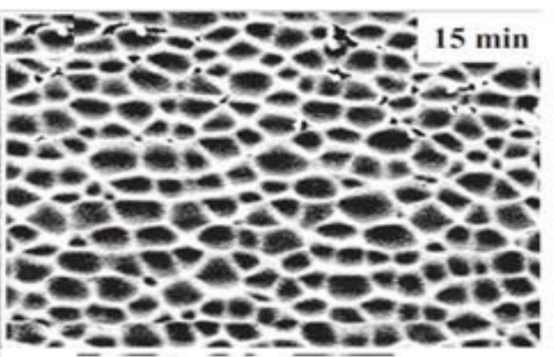

(b)

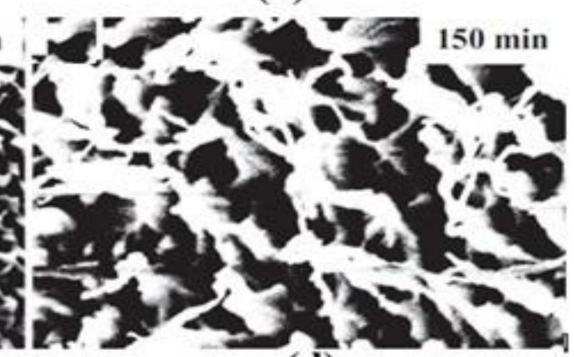

(d)

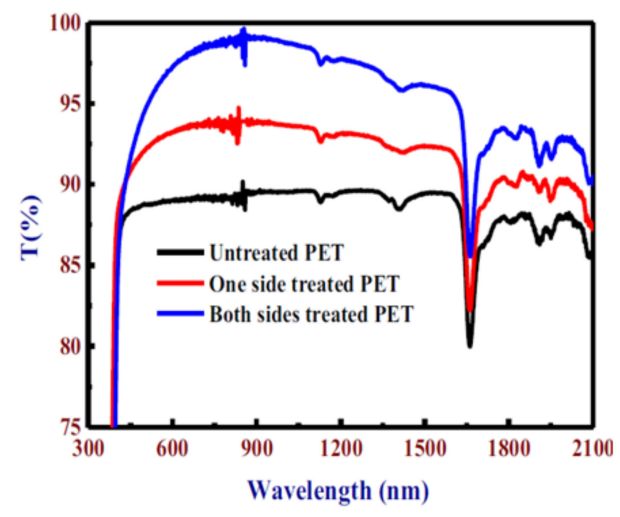

(ii)

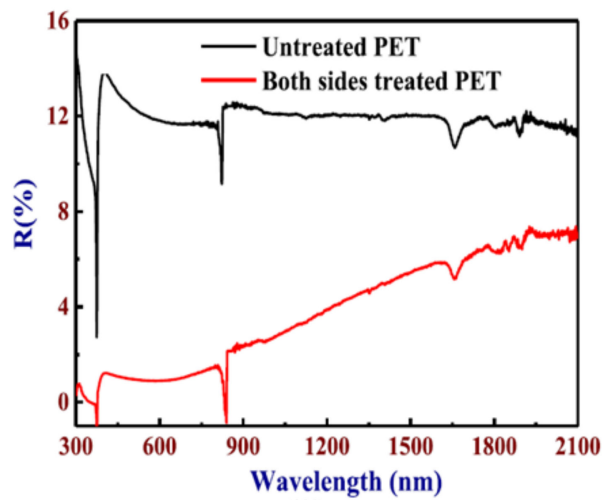

(iii)

Figure 23. (i) FESEM micrographs of (a) untreated PET (0 min) (b) treated PET for 15 min (c) 120 min (d) 150 min; (ii) Transmittance spectra of untreated, one side treated and both sides treated PET. (iii) Variation of reflectance for untreated and both sides treated PET. Reprinted with permission [195]; 2016, Elsevier.

The coating showed broadband, and quasi-omnidirectional antireflection performance and an optimized PET film resulted in a total transmittance of about $\sim 98 \%$ in the wavelength ranging from $660-1100 \mathrm{~nm}$ and a reflection of $\sim 3 \%$ at an incidence angle varying from $8^{\circ}$ to $48^{\circ}$. The high transmittance is primarily due to the gradient refractive index of the nanostructures. In this case, the optical properties were depending on the etching time.

\subsubsection{Other Polymers}

Apart from the commonly used polymers for PV applications discussed above, researchers also found many other polymers that address the Fresnel reflection loss. For example, Biswas et al. prepared nanoporous poly (methyl silsesquioxane) (PMSSQ) through the sacrificial-porogen approach that has been proposed as antireflection coatings [212]. In this method, the optical thickness can be optimized by adjusting spin-casting speed and varying the amount of organic polymer which controls the porosity and the solid content of the solution. The index of refraction ranges from 1.18 to 1.44 
owing to the variation in the thickness ranging from $10 \mathrm{~nm}$ to $1 \mu \mathrm{m}$. When fixing the refractive index at 1.3 , a high transmission value of $>99.7 \%$ is obtained in the visible wavelength span. Dai et al. prepared a single layer coating of a polymer blend comprising of PMMA/PS nanoparticles and deposited using a spin-coating technique demonstrated eminent AR performance [213]. The size of the particles can be optimized by tuning the synthesis parameters, which significantly affects the optical performance. The optimized antireflection coating exhibited a transmittance in the visible range of about $99.17 \%$. Further improvement can also be achieved via surface roughness modification. The transmittance spectra and the image of the substrate at various conditions are shown in Figure 24. A summary of polymer-based antireflection coatings is given in Table 5.

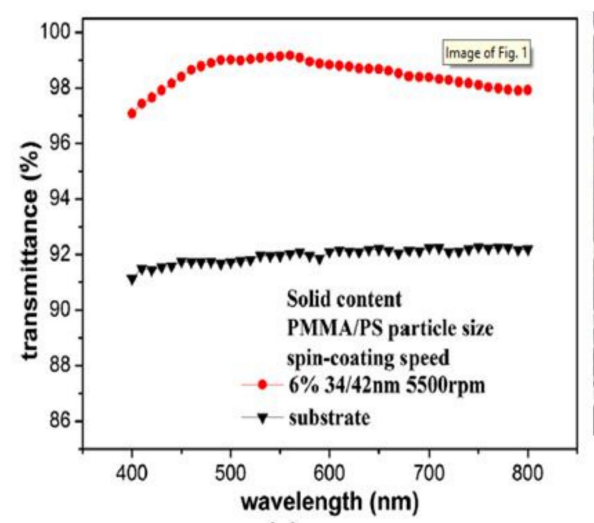

(a)

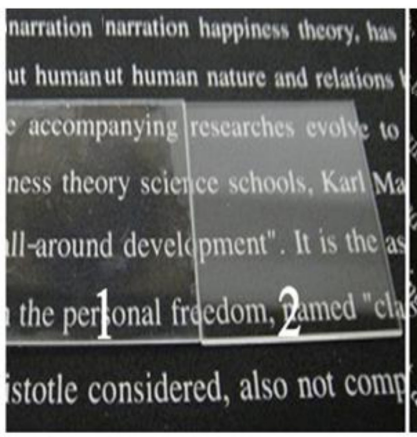

(b)

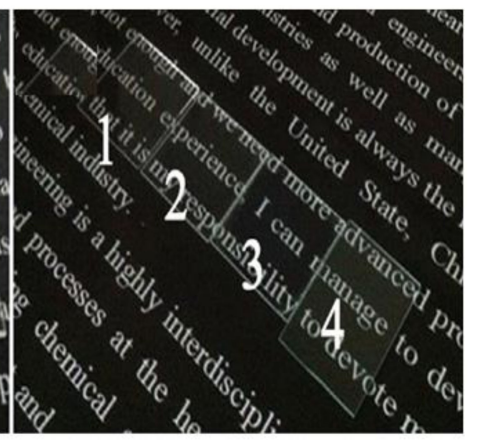

(c)

Figure 24. (a) Transmittance spectra of uncoated substrate and coated substrate in visible range (b) Images of substrate under bright light (1. Coated PMMA sheet; 2. bare PMMA sheet), (c) images of substrate under normal light (1. Uncoated PMMA sheet; 2. one-side coated PMMA sheet; 3. both sides coated PMMA sheet; 4. uncoated glass sheet). Reprinted with permission [213]; 2014, Elsevier. 
Table 5. Polymer based antireflection coatings.

\begin{tabular}{|c|c|c|c|c|c|c|c|c|}
\hline $\begin{array}{l}\text { AR Coating } \\
\text { Material }\end{array}$ & ARC Structure & $\begin{array}{l}\text { Fabrication } \\
\text { Technology }\end{array}$ & Reflectance (\%) & $\begin{array}{c}\text { Transmittance } \\
(\%)\end{array}$ & $\begin{array}{l}\text { Wavelength } \\
\text { (nm) }\end{array}$ & Features & Research Potential & Reference \\
\hline Polystyrene & $\begin{array}{l}\text { Biomimetic } \\
\text { nanopillars }\end{array}$ & $\begin{array}{l}\text { Microinjection } \\
\text { compression molding }\end{array}$ & $\sim 4$ & - & $400-1000$ & $\begin{array}{l}\text { Inspired from Cicada of wing } \\
\text { nanostructures and has a water } \\
\text { contact angle of } 143^{\circ} \pm 2^{\circ}\end{array}$ & $\begin{array}{l}\text { Experimental analysis of } \\
\text { the increase in PCE using } \\
\text { this coating }\end{array}$ & [197] \\
\hline Polystyrene & $\begin{array}{l}\text { Pyramid- } \\
\text { arrayed PS film }\end{array}$ & $\begin{array}{l}\text { Microinjection } \\
\text { compression molding }\end{array}$ & $\sim 5$ & 93 & $400-900$ & $\begin{array}{l}\text { PS coated thin-film PV cell } \\
\text { shown an improvement of } 7.9 \% \\
\text { increase in PCE }\end{array}$ & $\begin{array}{l}\text { Stability, reliability and } \\
\text { environmental effects } \\
\text { of/on the coating can be } \\
\text { analyzed }\end{array}$ & [6] \\
\hline PMMA & $\begin{array}{l}\text { Nano-cone } \\
\text { array }\end{array}$ & $\begin{array}{l}\text { Vacuum-assisted } \\
\text { surface wetting } \\
\text { methodology }\end{array}$ & 0.64 & 99.4 & $400-800$ & $\begin{array}{l}\text { Antireflection coating of } \\
\text { parabola shape made of } \\
\text { PMMA with nano-cone arrays }\end{array}$ & $\begin{array}{l}\text { Effect of this coating on } \\
\text { various solar cells to find } \\
\text { its suitable application }\end{array}$ & [193] \\
\hline PMMA & Nanopatterns & $\begin{array}{l}\text { Thermal } \\
\text { nanoimprinting, laser } \\
\text { lithography and dry } \\
\text { etching }\end{array}$ & $<0.5$ & - & $400-800$ & $\begin{array}{l}\text { Simple, large-scale and } \\
\text { cost-effective production }\end{array}$ & $\begin{array}{l}\text { Experimental analysis of } \\
\text { the increase in PCE using } \\
\text { this coating }\end{array}$ & [5] \\
\hline PDMS & Nano-domes & $\begin{array}{l}\text { Replica molding } \\
\text { approach }\end{array}$ & $<2$ & 95 & $400-900$ & $\begin{array}{l}\text { Broadband AR PDMS film } \\
\text { with a hemispherical } \\
\text { nano-domes structure }\end{array}$ & $\begin{array}{l}\text { The threshold of the } \\
\text { nanopatterned PDMS } \\
\text { film need to be } \\
\text { investigated }\end{array}$ & [206] \\
\hline PDMS & $\begin{array}{l}\text { Tappered } \\
\text { nanoholes } \\
(\mathrm{NHs})\end{array}$ & Soft lithography & $\sim 7.1$ & - & $350-800$ & $\begin{array}{l}\text { When the film is used on a } \\
\text { DSSC, the PCE enhanced to } \\
7.56 \% \text { from } 7.15 \%\end{array}$ & $\begin{array}{l}\text { Stability, reliability and } \\
\text { environmental effects } \\
\text { of/on the coating can be } \\
\text { analyzed }\end{array}$ & [94] \\
\hline
\end{tabular}


Table 5. Cont

\begin{tabular}{|c|c|c|c|c|c|c|c|c|}
\hline $\begin{array}{l}\text { AR Coating } \\
\text { Material }\end{array}$ & ARC Structure & $\begin{array}{l}\text { Fabrication } \\
\text { Technology }\end{array}$ & Reflectance (\%) & $\begin{array}{c}\text { Transmittance } \\
(\%)\end{array}$ & $\begin{array}{l}\text { Wavelength } \\
\text { (nm) }\end{array}$ & Features & Research Potential & Reference \\
\hline PET & $\begin{array}{l}\text { Nano-cone } \\
\text { array }\end{array}$ & Reactive-ion Etching & $\sim 0.5$ & $\sim 97$ & $300-900$ & $\begin{array}{l}\text { The film exhibits } \\
\text { superhydrophobic properties }\end{array}$ & $\begin{array}{l}\text { Effect of this coating on } \\
\text { various solar cells to find } \\
\text { its suitable application }\end{array}$ & [190] \\
\hline PET & $\begin{array}{l}\text { Nano-porous } \\
\text { patterns }\end{array}$ & Plasma etching & - & $\sim 98$ & $660-1100$ & $\begin{array}{l}\text { The coating showed broadband } \\
\text { and quasi- omnidirectional } \\
\text { antireflection performance }\end{array}$ & $\begin{array}{l}\text { Experimental analysis of } \\
\text { the increase in PCE using } \\
\text { this coating }\end{array}$ & [195] \\
\hline $\begin{array}{l}\text { Poly(methylsil } \\
\text { sesquioxane) } \\
\text { (PMSSQ) }\end{array}$ & $\begin{array}{l}\text { Nanoporous } \\
\text { poly(methylsil } \\
\text { sesquioxane) } \\
\text { (PMSSQ) films }\end{array}$ & $\begin{array}{l}\text { Sacrificial-porogen } \\
\text { approach }\end{array}$ & - & $>99.7$ & $400-800$ & $\begin{array}{l}\text { The refractive indices ranges } \\
\text { from } 1.44 \text { to as low as } 1.18\end{array}$ & $\begin{array}{l}\text { Stability, reliability and } \\
\text { environmental effects } \\
\text { of/on the coating can be } \\
\text { analyzed }\end{array}$ & [212] \\
\hline $\begin{array}{l}\text { Poly(methyl } \\
\text { methacrylate)/ } \\
\text { polystyrene }\end{array}$ & $\begin{array}{l}\text { PMMA/PS } \\
\text { nanoparticles }\end{array}$ & Spin-coating method & - & 99.17 & $400-800$ & $\begin{array}{l}\text { Improved transmittance } \\
\text { obtained from the modification } \\
\text { of surface roughness }\end{array}$ & $\begin{array}{l}\text { Transmission can be } \\
\text { analyzed and improved } \\
\text { for broadband } \\
\text { wavelength, and PCE } \\
\text { analysis can be } \\
\text { considered }\end{array}$ & [213] \\
\hline Epoxy resin & $\begin{array}{l}\text { Biomimetic } \\
\text { diodon-skin } \\
\text { nanothorn } \\
\text { (DSNT) epoxy } \\
\text { resin ARC }\end{array}$ & $\begin{array}{l}\text { Soft imprint } \\
\text { lithography }\end{array}$ & $\sim 15.8$ & - & $300-1100$ & $\begin{array}{l}\text { PCE of the silicon PV cell is } \\
\text { increased from } 18.99 \% \text { to } \\
19.88 \%\end{array}$ & $\begin{array}{l}\text { Effect of this coating on } \\
\text { various solar cells to find } \\
\text { its suitable application }\end{array}$ & [214] \\
\hline
\end{tabular}




\subsection{Composites}

For achieving a minimum reflection for broad wavelength span, layers of ARCs need to be stacked. Researchers have developed many combinations of materials to improve the overall antireflective property of the coating. Likewise, Liu et al. reported a bilayer of $\mathrm{SiO}_{2}$ and $\mathrm{TiO}_{2}$ film fabricated through a facile sol-dip coating method having an excellent antireflective and self-cleaning property [215]. The $\mathrm{TiO}_{2}$ layer enhances the self-cleaning ability of the film, and the $\mathrm{SiO}_{2}$ layer having a low refractive index acts as an AR coating. The maximum transmittance of DLARC at normal incidence attained about 96.7\%. Lien et al. prepared $\mathrm{TiO}_{2} \mathrm{SLARC}, \mathrm{SiO}_{2} / \mathrm{TiO}_{2}$ DLARC, and $\mathrm{SiO}_{2} / \mathrm{SiO}_{2}-\mathrm{TiO}_{2} / \mathrm{TiO}_{2}$ triple-layer AR coatings and deployed on the silicon solar cells through sol-gel method [216]. The average reflectance exhibited was $9.3 \%, 6.2 \%$, and $3.2 \%$ in the $400-1000 \mathrm{~nm}$ wavelength range for SLARC, DLARC, and triple-layer AR coatings, respectively. Further, it was reported an enhancement of $39 \%$ in the PCE of the monocrystalline silicon cell, indicating the potential of low-cost sol-gel processed ARC. The combination of $\mathrm{SiO}_{2}$ and $\mathrm{TiO}_{2}$ film has many advantages, such as excellent stability, photocatalytic activity, non-toxic, thermal stability, and chemical resistance [217-222]. Tao et al. also worked on double-layer $\mathrm{TiO}_{2}-\mathrm{SiO}_{2}$ broadband ARC prepared by the sol-gel technique [223]. The RI can be tuned from 1.19 to 1.45 by controlling the incorporation of $\mathrm{TiO}_{2}$ into the $\mathrm{SiO}_{2}$ layer largely consists of nanopores. The double-layer coating demonstrated the highest transmittance and the average transmittance of $98.4 \%$ and $97.7 \%$ in the visible and near-IR region. This work contributes to a different path to refine the refractive indices of ARC, which usually depends on the preparation process parameters. Mazur et al. fabricated an ARC consisting of a combination of five $\mathrm{TiO}_{2}$ and $\mathrm{SiO}_{2}$ thin films, and a microwave-assisted reactive magnetron sputtering method was employed for the deposition of these films [224]. The deposition of a thin $\mathrm{TiO}_{2}$ layer helps in achieving the photocatalytic effect, and the coating exhibited a WCA greater than $90^{\circ}$. The overall transmittance of ARC was greater than $97 \%$ in the target wavelength range. The prepared coating was scratch resistant, hydrophobic, photo-catalytically active, and possessed increased hardness with good transmittance.

In order to achieve a low reflectivity, the usage of metallic nanoparticles on a thin dielectric film [225-231], metal-dielectric-metal hybrid microstructure [232] is reported. Sun et al. prepared an ARC composed of nanostructured Ag and silica coatings [233]. The transmittance and scattering characteristics of the coating are improved by utilizing the localized surface plasmon resonance, and the nanostructured Ag exhibited an increased forward scattering and low indices of refraction for $\mathrm{Ag} / \mathrm{SiO}{ }_{2}$ coatings. The transmittance values of ARCs with $0.10 \mathrm{wt} \% \mathrm{Ag}$ annealed at $400{ }^{\circ} \mathrm{C}$ were $95.7 \%$ and $97.2 \%$ for single-side, and both sides coated glass samples in the visible wavelength range. Recently, Huang created a broadband low reflection ARC with Ag nanospheres on Si nanopillar arrays [234]. The results showed that the average reflection reached up to $2.66 \%$ in $400-1100 \mathrm{~nm}$ wavelength range owing to the AR properties of Si nanopillars and the forward scattering effect of Ag nanospheres. The optical properties primarily depend on the dimensions of Si nanopillars and Ag nanospheres and also on the period of the arrays.

$\mathrm{Li}$ et al. developed a composite ARC comprised of nanoporous $\mathrm{ZnO} / \mathrm{SiO}_{2}$ bilayer using a sol-gel dip-coating method on the glass sample [235]. The refractive indices of 1.34 and 1.21 at $550 \mathrm{~nm}$ wavelength is obtained for $\mathrm{ZnO}$ and $\mathrm{SiO}_{2}$ layer, respectively. When the optical properties were analyzed, a broadband AR performance was obtained throughout the solar spectrum with an improvement of $6.5 \%$ and $6.2 \%$ transmittance in the wavelength span of 300-1200 $\mathrm{nm}$ and $1200-2500 \mathrm{~nm}$, respectively. Salman et al. used $\mathrm{ZnO}$ /porous silicon layer as AR coating in which the porous silicon (PSi) was prepared by photoelectrochemical etching methodology, and the ZnO layer was coated on PSi layer by using radiofrequency sputtering technique [236]. A high-quality Zinc oxide nano-crystalline coating was obtained, which was indicated by Raman measurements at room temperature. The coating exhibited excellent antireflection properties with the lowest effective reflectance in the 400-1000 nm wavelength range, which in turn raised the efficiency to $18.15 \%$. Another study reported a DLARC composed of $\mathrm{MgF}_{2}$ and $\mathrm{ZnO}$ nanorod layers [237]. The coating was developed on gallium doped $\mathrm{MgZnO}$ transparent conducting oxide layer of CIGS solar cells. The global weighted reflectance was 
reduced to $5.5 \%$, and the efficiency is enhanced to about $17 \%$. This enhancement is primarily attributed to a decreased reflection loss due to the gradually changing refractive index of the DLAR coating.

Wuu et al. investigated liquid phase deposited $\mathrm{Al}_{2} \mathrm{O}_{3} / \mathrm{TiO}_{2}$ double-layer antireflection coating on polished $\mathrm{Si}$ substrate [238]. For $\mathrm{Al}_{2} \mathrm{O}_{3}$ deposition, aluminum sulfate and sodium bicarbonate were employed, and to deposit $\mathrm{TiO}_{2}$, a solution of ammonium hexafluoro-titanate and boric acid were utilized. The deposition rate is controlled by the varying concentration of sodium bicarbonate and boric acid. The optimized film exhibited an average refractive index of 1.58 and 1.76 for $\mathrm{Al}_{2} \mathrm{O}_{3}$ and $\mathrm{TiO}_{2}$ films, respectively, and the average reflectance in 400 to $800 \mathrm{~nm}$ the wavelength range was $3.3 \%$ for a thickness of $99 \mathrm{~nm} \mathrm{Al}_{2} \mathrm{O}_{3}$ film and $89 \mathrm{~nm} \mathrm{TiO} 2$ film. The structure and the measured reflectance spectra are shown in Figure 25. Sharma et al. compared a single layer ARC of $\mathrm{MgF}_{2}$ and multilayer composite ARC consists of $\mathrm{Al}_{2} \mathrm{O}_{3} / \mathrm{TiO}_{2} / \mathrm{SiO}_{2}$, which are deposited using E-beam deposition technique [239]. The thickness of each layer was optimized for both single-layer and multilayer ARC. The single ARC and multilayer ARC exhibited a peak transmittance of $96.41 \%$ and $94.09 \%$, respectively. Rajvikram et al. employed cost-effective coatings with the structure of $\mathrm{Al}_{2} \mathrm{O}_{3} / \mathrm{Ta}_{2} \mathrm{O}_{3} / \mathrm{Al}_{2} \mathrm{O}_{3}$ to minimize the reflection loss and thereby, increasing the PCE of the PV cell [240]. Recently, Qiang-Ma et al. [241] constructed and compared two quadruple layers of antireflection coating in which the top three layers $\left(\mathrm{SiO}_{2} / \mathrm{SiNx} / \mathrm{SiNx}\right)$ were common. The bottom layer of one quadruple $\mathrm{ARC}$ was composed of the $\mathrm{Al}_{2} \mathrm{O}_{3}$ layer deposited by DC reactive magnetron sputtering, and the bottom layer of the other quadruple ARC consists of $\mathrm{SiO}_{2}$ layer deposited by PECVD. The solar cell coated with quadruple ARC was compared with a solar cell coated with DLARC of $\mathrm{SiNx}: \mathrm{H}$, and it is found that the reflectance of the quadruple layer coated cell is lesser than the other. Kim et al. prepared a novel self-cleaning ARC using plasma-polymerized fluorocarbon (PPFC) on $\mathrm{Nb}_{2} \mathrm{O}_{5} / \mathrm{SiO}_{2} / \mathrm{Nb}_{2} \mathrm{O}_{5}$ (NSN) tri-layers [242]. The PPFC/NSN antireflection films demonstrated decreased reflectance in the visible range, and it exhibited a reflectance of $1.71 \%$ at $528 \mathrm{~nm}$ wavelength for PPFC layer thickness of $70 \mathrm{~nm}$. The ARC also demonstrated a hydrophobic character having a water contact angle of $105^{\circ}$. When this ARC is deposited on perovskite solar cells, its PCE was increased to $17 \%$. The reflection spectra and the TEM image is shown in Figure 26. Uzum et al. prepared a polymer-based composite antireflection film by the spin-coating method [243]. The fabricated polymer-based $\mathrm{ZrO}_{2}$ and surface deactivated $\mathrm{TiO}_{2}$ multilayer composite film exhibited an average reflectance of $5.5 \%$, and when these films deposited on the silicon solar cells, the PCE was enhanced by $0.8 \%$ relative to the uncoated cell. Rajvikram et al., adopted $\mathrm{ZnS}_{-} \mathrm{SiO}_{2}-\mathrm{ZnS}$ multilayer coating on the solar panel, and a 3.5\% rise in the efficiency is obtained comparatively with the uncoated solar panel [244]. A summary of composite antireflection coatings is provided in Table 6.

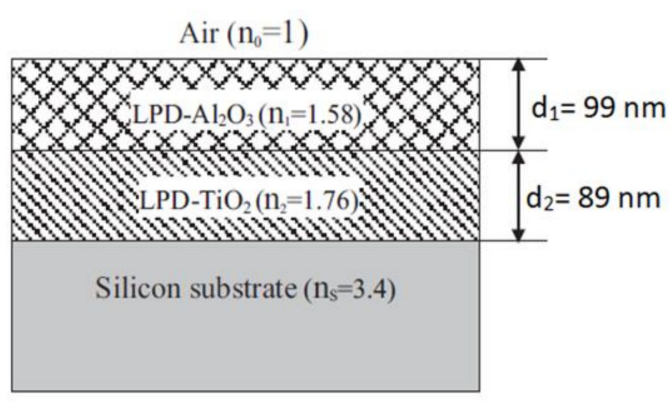

(a)

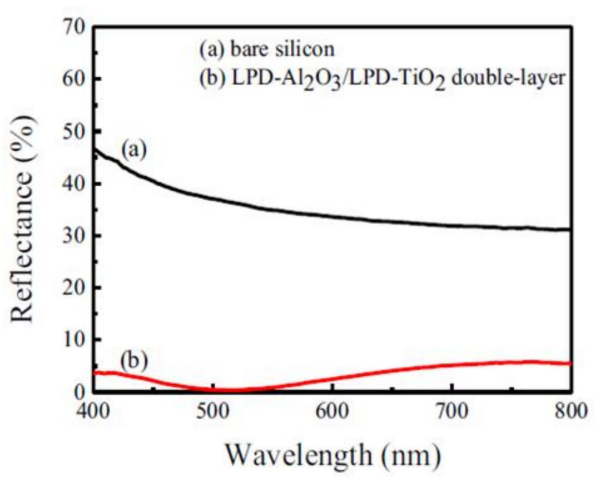

(b)

Figure 25. (a) Structural diagram of double layer $\mathrm{LPD}-\mathrm{Al}_{2} \mathrm{O}_{3} / \mathrm{LPD}-\mathrm{TiO}_{2}$ ARCs. (b) Variation of measured reflectance for the LPD- $\mathrm{Al}_{2} \mathrm{O}_{3} / \mathrm{LPD}-\mathrm{TiO}_{2}$ DLARCs on polished silicon substrate and bare silicon. Reprinted with permission [238]; 2015, Elsevier. 
Table 6. Composite material antireflection coatings.

\begin{tabular}{|c|c|c|c|c|c|c|c|c|}
\hline $\begin{array}{l}\text { AR Coating } \\
\text { Material }\end{array}$ & ARC Structure & $\begin{array}{l}\text { Fabrication } \\
\text { Technology }\end{array}$ & Reflectance (\%) & $\begin{array}{c}\text { Transmittance } \\
(\%)\end{array}$ & $\begin{array}{l}\text { Wavelength } \\
\text { (nm) }\end{array}$ & Features & Research Potential & Reference \\
\hline $\mathrm{SiO}_{2}$ and $\mathrm{TiO}_{2}$ & $\mathrm{SiO}_{2} / \mathrm{TiO}_{2}$ DLARC & $\begin{array}{l}\text { Sol-gel dip-coating } \\
\text { method }\end{array}$ & - & 92 & $350-800$ & $\begin{array}{l}\text { Super-hydrophilic with water } \\
\text { contact angle less than } 2^{\circ}\end{array}$ & $\begin{array}{l}\text { Experimental analysis of } \\
\text { the increase in PCE using } \\
\text { this coating }\end{array}$ & [215] \\
\hline $\mathrm{SiO}_{2}$ and $\mathrm{TiO}_{2}$ & $\begin{array}{ll}\text { (i) } & \mathrm{TiO}_{2} \mathrm{SLARC} \\
\text { (ii) } & \mathrm{SiO}_{2} / \mathrm{TiO}_{2} \text { DLARC } \\
\text { (iii) } & \mathrm{SiO}_{2} / \mathrm{SiO}_{2} \\
& -\mathrm{TiO}_{2} / \mathrm{TiO}_{2} \text { triple-layer }\end{array}$ & Sol-gel method & $\begin{array}{ll}\text { (i) } & 9.3 \\
\text { (ii) } & 6.2 \\
\text { (iii) } & 3.2\end{array}$ & - & $400-1000$ & $\begin{array}{l}\text { An enhancement of } 39 \% \text { in } \\
\text { PCE of a mono c-Si PV cell is } \\
\text { obtained with triple-layer ARC }\end{array}$ & $\begin{array}{l}\text { Effect of this coating on } \\
\text { various solar cells to find } \\
\text { its suitable application }\end{array}$ & [216] \\
\hline $\mathrm{SiO}_{2}$ and $\mathrm{TiO}_{2}$ & $\mathrm{SiO}_{2} / \mathrm{TiO}_{2}$ DLARC & $\begin{array}{l}\text { Surface sol-gel } \\
\text { process }\end{array}$ & - & 97.7 & $400-1200$ & $\begin{array}{l}\text { Multifunctional ARC with high } \\
\text { performance, wide wavelength } \\
\text { range, and high environmental } \\
\text { stability }\end{array}$ & $\begin{array}{l}\text { Experimental analysis of } \\
\text { the increase in PCE using } \\
\text { this coating }\end{array}$ & [223] \\
\hline $\mathrm{SiO}_{2}$ and $\mathrm{TiO}_{2}$ & Five $\mathrm{TiO}_{2}$ and $\mathrm{SiO}_{2}$ thin films & $\begin{array}{l}\text { Microwave assisted } \\
\text { reactive magnetron } \\
\text { sputtering process }\end{array}$ & - & 97 & $450-780$ & $\begin{array}{l}\text { Improved hardness, high } \\
\text { photocatalytic activity, } \\
\text { scratch-resistant, and } \\
\text { hydrophobic }\end{array}$ & $\begin{array}{l}\text { Transmission can be } \\
\text { analyzed and improved } \\
\text { for broadband } \\
\text { wavelength }\end{array}$ & [224] \\
\hline $\mathrm{Ag}$ and $\mathrm{SiiO}_{2}$ & Nanostructured Ag and silica & $\begin{array}{l}\text { Localized surface } \\
\text { plasmon resonance }\end{array}$ & - & 97.2 & $400-800$ & $\begin{array}{l}\text { Low refractive index and high } \\
\text { forward scattering is obtained }\end{array}$ & $\begin{array}{l}\text { Effect of this coating on } \\
\text { various solar cells to find } \\
\text { its suitable application }\end{array}$ & [233] \\
\hline $\mathrm{Ag}$ and Silicon & $\begin{array}{l}\text { Ag nanosphereson } \mathrm{Si} \\
\text { nanopillar arrays }\end{array}$ & Simulation Research & 2.66 & - & $400-1100$ & $\begin{array}{l}\text { Practicable method for the } \\
\text { optimization of antireflection } \\
\text { in different device applications }\end{array}$ & $\begin{array}{l}\text { Experimental analysis of } \\
\text { the increase in PCE using } \\
\text { this coating }\end{array}$ & [234] \\
\hline $\mathrm{ZnO}$ and $\mathrm{SiO}_{2}$ & $\begin{array}{l}\text { Nanoporous } \mathrm{ZnO} / \mathrm{SiO}_{2} \\
\text { bilayer coating }\end{array}$ & $\begin{array}{l}\text { Sol-gel dip-coating } \\
\text { method }\end{array}$ & - & $6.5 \%$ increase & $300-1200$ & $\begin{array}{l}\text { Broadband antireflection } \\
\text { performance of the bilayer } \\
\text { structure }\end{array}$ & $\begin{array}{l}\text { Stability, reliability and } \\
\text { environmental effects } \\
\text { of/on the coating can be } \\
\text { analyzed }\end{array}$ & [235] \\
\hline $\mathrm{ZnO}$ and Silicon & $\mathrm{ZnO} /$ porous silicon layer & $\begin{array}{l}\text { Photoelectrochemical } \\
\text { etching methodology } \\
\text { and radio frequency } \\
\text { sputtering technique }\end{array}$ & - & - & $400-1000$ & $\begin{array}{l}\text { Increased the efficiency of the } \\
\text { solar cell to } 18.15 \%\end{array}$ & $\begin{array}{l}\text { Transmission and } \\
\text { reflectance values can be } \\
\text { obtained }\end{array}$ & [236] \\
\hline $\mathrm{MgF}_{2}$ and $\mathrm{ZnO}$ & $\begin{array}{l}\text { Double layer } \mathrm{MgF}_{2} \text { and } \mathrm{ZnO} \\
\text { nanorods layer }\end{array}$ & RF sputtering & 5.5 & - & $300-1000$ & $\begin{array}{l}\text { An enhanced PCE of } 17 \% \text { in } \\
\text { CIGS solar cells }\end{array}$ & $\begin{array}{l}\text { Stability, reliability and } \\
\text { environmental effects } \\
\text { of/on the coating can be } \\
\text { analyzed }\end{array}$ & [237] \\
\hline
\end{tabular}


Table 6. Cont

\begin{tabular}{|c|c|c|c|c|c|c|c|c|}
\hline $\begin{array}{l}\text { AR Coating } \\
\text { Material }\end{array}$ & ARC Structure & $\begin{array}{l}\text { Fabrication } \\
\text { Technology }\end{array}$ & Reflectance (\%) & $\begin{array}{c}\text { Transmittance } \\
(\%)\end{array}$ & $\begin{array}{l}\text { Wavelength } \\
(\mathrm{nm})\end{array}$ & Features & Research Potential & Reference \\
\hline $\mathrm{Al}_{2} \mathrm{O}_{3}$ and $\mathrm{TiO}_{2}$ & $\mathrm{Al}_{2} \mathrm{O}_{3} / \mathrm{TiO}_{2}$ DARC & $\begin{array}{l}\text { Liquid phase } \\
\text { deposition }\end{array}$ & 3.3 & - & $400-800$ & $\begin{array}{l}\text { Highly favorable method for } \mathrm{Si} \\
\text { PV cells }\end{array}$ & $\begin{array}{l}\text { Experimental analysis of } \\
\text { the increase in PCE using } \\
\text { this coating }\end{array}$ & [238] \\
\hline $\begin{array}{c}\mathrm{Al}_{2} \mathrm{O}_{3}, \mathrm{TiO}_{2} \\
\mathrm{SiO}_{2} \text { and } \mathrm{MgF}_{2}\end{array}$ & $\begin{array}{ll}\text { (i) } & \text { Single layer } \mathrm{MgF}_{2} \\
\text { (ii) } & \mathrm{Multilayer} \\
\mathrm{Al}_{2} \mathrm{O}_{3} / \mathrm{TiO}_{2} / \mathrm{SiO}_{2}\end{array}$ & $\begin{array}{l}\text { E-beam deposition } \\
\text { technique }\end{array}$ & $\begin{array}{ll}\text { (i) } & 5.28 \\
\text { (ii) } & 8.97\end{array}$ & $\begin{array}{ll}\text { (i) } & 94.72 \\
\text { (ii) } & 91.03\end{array}$ & $400-700$ & $\begin{array}{l}\text { These filters can be used for } \\
\text { applications such as } \\
\text { transparent industrial display } \\
\text { systems, relay optics in } \\
\text { complex optical instruments }\end{array}$ & $\begin{array}{l}\text { Transmission can be } \\
\text { analyzed and improved } \\
\text { for broadband } \\
\text { wavelength, and PCE } \\
\text { analysis can be } \\
\text { considered }\end{array}$ & [239] \\
\hline $\begin{array}{l}\mathrm{SiO}_{2}, \mathrm{Al}_{2} \mathrm{O}_{3} \text { and } \\
\mathrm{SiNx}\end{array}$ & $\begin{array}{ll}\text { (i) } & \text { Double layer } \mathrm{SiNx}: \mathrm{H} \\
\text { (ii) } & \text { Quadruple } \\
& \mathrm{SiO}_{2} / \mathrm{SiNx} / \mathrm{SiNx} / \mathrm{SiO}_{2} \\
\text { (iii) } & \text { Quadruple } \\
& \mathrm{SiO}_{2} / \mathrm{SiNx} / \mathrm{SiNx} / \mathrm{Al}_{2} \mathrm{O}_{3}\end{array}$ & $\begin{array}{l}\text { DC reactive } \\
\text { magnetron sputtering } \\
\text { and PECVD }\end{array}$ & $\begin{array}{ll}\text { (i) } & 9.9 \\
\text { (ii) } & 5.4 \\
\text { (iii) } & 4.5 \%\end{array}$ & - & $350-1100$ & $\begin{array}{l}\text { Optimal design of } \\
\text { quadruple-layer antireflection } \\
\text { coating }\end{array}$ & $\begin{array}{l}\text { Experimental analysis of } \\
\text { the increase in PCE using } \\
\text { this coating }\end{array}$ & [241] \\
\hline PPFC and NSN & $\begin{array}{l}\mathrm{PPFC} \text { on } \mathrm{Nb}_{2} \mathrm{O}_{5} / \mathrm{SiO}_{2} / \\
\mathrm{Nb}_{2} \mathrm{O}_{5} \text { (NSN) trilayers }\end{array}$ & $\begin{array}{l}\text { Roll to roll sputtering } \\
\text { and plasma treatment }\end{array}$ & 1.71 & - & 528 & $\begin{array}{l}\text { Possesses a water contact angle } \\
\text { of } 100^{\circ}\end{array}$ & $\begin{array}{l}\text { Effect of this coating on } \\
\text { various solar cells to find } \\
\text { its suitable application }\end{array}$ & [242] \\
\hline $\begin{array}{l}\mathrm{SiO}_{2}, \mathrm{PEG} \text { and } \\
\text { polyvinyl } \\
\text { pyrrolidone }\end{array}$ & $\begin{array}{ll}\text { (a) } & \mathrm{SiO}_{2} \text {-Polyethylene } \\
& \text { glycol (PEG) } \\
\text { (b) } & \mathrm{SiO}_{2} \text { polyvinyl } \\
& \text { pyrrolidone (PVP) }\end{array}$ & $\begin{array}{l}\text { Sol-gel dip-coating } \\
\text { method }\end{array}$ & - & 97 & $450-700$ & $\begin{array}{l}\text { The enhancement of PCE of } \\
\mathrm{SiO}_{2}-\mathrm{PVP} \text { and } \mathrm{SiO}_{2} \text { - PEG AR } \\
\text { coatings are } 8.33 \% \text { and } 7.27 \% \text {, } \\
\text { respectively }\end{array}$ & $\begin{array}{l}\text { Stability, reliability and } \\
\text { environmental effects } \\
\text { of/on the coating can be } \\
\text { analyzed }\end{array}$ & [245] \\
\hline Silica and PET & $\begin{array}{l}\text { Single-layered porous silica } \\
\text { films on polyethylene } \\
\text { terephthalate (PET) } \\
\text { substrates }\end{array}$ & $\begin{array}{l}\text { Template synthesis } \\
\text { and spin-coating } \\
\text { method }\end{array}$ & $<2$ & - & $400-800$ & $\begin{array}{l}\text { ARC for efficient, large-scale } \\
\text { flexible optoelectronics devices }\end{array}$ & $\begin{array}{l}\text { Research to improve } \\
\text { transmittance further can } \\
\text { be considered, and } \\
\text { together with PCE } \\
\text { analysis can be } \\
\text { considered }\end{array}$ & [246] \\
\hline
\end{tabular}




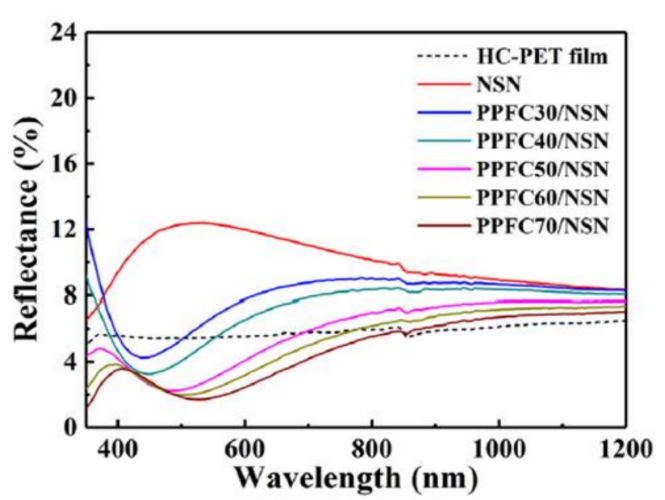

(a)

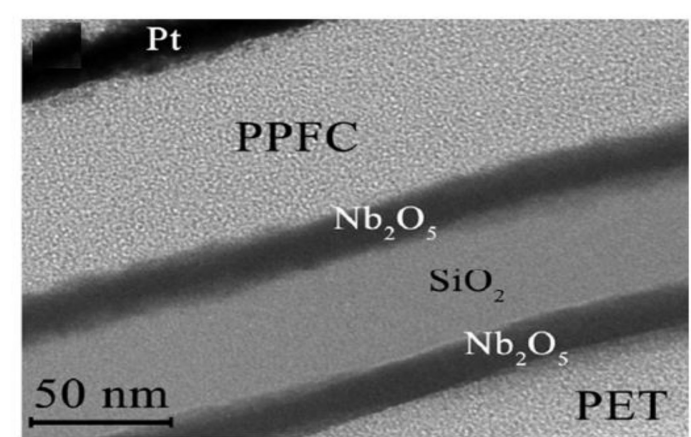

(b)

Figure 26. (a) Reflection spectra of HC-PET substrate film, trilayered NSN thin film, and quadrilayered PPFC/NSN thin films in 350 to $1200 \mathrm{~nm}$ wavelength range. (b) Cross-sectional TEM image of quadrilayered PPFC70/NSN thin film. Reprinted with permission [242]; 2019, Elsevier.

\subsection{Other Advanced Materials}

Several researchers have contributed their efforts in this wonder material, 'graphene' which has a massive potential in the material sector possessing numerous desirable properties. It consists of a two-dimensional carbon hexagonal ring with a uniform honeycomb crystal lattice structure. Graphene can be warped to form fullerene (zero dimension), an allotrope of carbon. One-dimensional carbon nanotubes (CNTs) can be formed by rolling the graphene layer or can be stacked on one another to form a three-dimensional graphite structure. Moreover, it is regarded as an ideal material for the electrode in PV devices and is extensively being researched. Such materials have also found applications in PV devices as an active component in solar cells [247-250]. For instance, recently, Auguita et al. reported an ultrathin graphene layer developed by stacking of layers and nanotexturing of metal nanopatterns. This graphene layer possesses highly efficient optical absorption properties over a broad wavelength range from mid-infrared (IR) to ultraviolet (UV) [251], achieving a super broadband antireflectivity and a light absorption efficiency as high as $99 \%$. Choi et al. prepared graphene-based Schottky junction solar cells in which a graphene film is deposited on Si substrate as an ARC to improve the performance [252]. The fabricated cell attained a PCE of $12.5 \%$. Kim et al. developed a Si quantum dots based solar cell in which graphene is used as transparent conductive electrodes [253]. The graphene layer is doped with two different materials, such as $\mathrm{AuCl}_{3}$ and silver nanowires. This layer also suppresses the reflection, and a maximum power conversion efficiency of $16.2 \%$ is obtained.

Nicola et al. progressed an AR coating made of single-walled CNT (SWCNT) thin-film on Si substrate. It is prepared by using a solution-processing method followed by dry-transfer printing [254]. The optical properties rely on the thickness of the SWCNT coating, and the coating exhibited broadband and omnidirectional AR performance. This research team also prepared multi-walled carbon nanotube (MWCNT) on air-stabled silicon heterojunction solar cells by the vacuum filtration process. The developed solar cell showed a PCE of about 10\% when exposed to the air, even for a month [255]. Fullerene and its derivatives are regarded as suitable candidates for PV devices owing to their excellent geometric structure and high electron affinity. George et al. developed a functional fullerene derivative and incorporated into the inverted PV configuration to improve the efficiency of about 3\% [256]. Contrarily, Wang et al. prepared the C60 pyrrolidine tris-acid (CPTA) film and deposited as an electron transport layer by a spin-coated method on a perovskite solar cells (PSCs) [257]. The PSC device with ITO and flexible substrate attained a power conversion efficiency of $18.39 \%$ and $17.04 \%$, respectively. These materials are highly ascribed owing to their excellent mechanical and electrical properties. In par with the development of the technologies, many preparation techniques have been consistently improved to achieve smooth and reliable fabrication methodology for these materials, and they have become pioneering materials for optoelectronic devices. 


\section{Antireflection Coatings on PV Cell}

The fundamentals for the antireflection coatings, analysis of AR coating's reported structures and surfaces, their commonly used method of fabrication, and a brief review on AR coatings on the basis of materials used, are covered in the above sections. In this section, the currently used and succeeded coatings are reviewed, whereas the previous section would give a grasp of possible materials that have the prospective role in acting as antireflection coatings on PV modules.

Initially, in the solar cells, the antireflective properties are imparted by providing roughness on the surface of the silicon wafer. Solar cells have then experimented with $\mathrm{SiO}_{2}$, and $\mathrm{TiO}_{2} \mathrm{ARC}$ in which $\mathrm{SiO}_{2}$ wasn't optically favorable with silicon solar cells owing to its high refractive index and $\mathrm{TiO}_{2}$ ARC did not contribute to surface passivation although it is a better candidate for ARC. After years of research and development, $\mathrm{Si}_{3} \mathrm{~N}_{4}$ is found to be a suitable material for ARC with excellent surface passivation properties that developed into an industry trend. The research work considered in this section is reviewed based on distinct AR material coated on different types of solar cells and the subsequent impact on its efficiency. Usually, the common materials are utilized for antireflection coatings on silicon solar cells are silicon nitride $(\mathrm{SiNx})$, Silicon oxide $\left(\mathrm{SiO}_{2}\right)$, titanium dioxide $\left(\mathrm{TiO}_{2}\right)$, tin dioxide $\left(\mathrm{SnO}_{2}\right)$, zinc sulfide $(\mathrm{ZnS})$, zinc oxide $(\mathrm{ZnO})$ [258-261].

\subsection{Monocrystalline Silicon Solar Cells}

The monocrystalline silicon solar cells have specially opted for its good efficiency and ARC materials such as $\mathrm{ZnS}, \mathrm{SiO}_{2}$ and $\mathrm{TiO}_{2}$ have been researched with monocrystalline $\mathrm{Si}$ solar cells. Gangopadhyay et al. reported a Zinc sulfide antireflection coating on monocrystalline Si solar cells through chemical bath deposition (CBD). The work attempts to achieve an optimized molar percentage for various chemical bath constituents to improve the refractive index, uniformity of film deposited, and for effective reduction of reflection [262]. With proper optimization, high uniformity along with a refractive index of 2.35 is obtained, which reduced the average reflection to about 0.655 . Considering the electrical parameters, the short circuit current is increased by $6.55 \%$, and an improvement in the PCE of $5 \%$ is obtained for chemical bath deposited ZnS ARC coating compared to textured monocrystalline Si solar cells. The $\mathrm{ZnS}$ coated solar cell is reported to achieve a $13.8 \%$ PCE over a large area $(103 \times 103 \mathrm{~mm})$. Kern et al. have demonstrated a $44 \%$ increase in PCE after depositing a single-layer $\mathrm{TiO}_{2}$ antireflection coating [132]. Green et al. employed $\mathrm{MgF}_{2} / \mathrm{ZnS}$ DLARCs on silicon cells and the efficiency is boosted to $19.1 \%$ [263]. Another study by Lien et al. analyzed three different coatings, namely $\mathrm{TiO}_{2} \mathrm{SLARC}, \mathrm{SiO}_{2} / \mathrm{TiO}_{2}$ DLARC, and $\mathrm{SiO}_{2} / \mathrm{SiO}_{2}-\mathrm{TiO}_{2} / \mathrm{TiO}_{2}$ triple-layer AR coating is deposited on non-textured monocrystalline silicon cell through sol-gel spin-coating method [216]. By controlling the spinning rate and the concentration of alcohol in the sol-gel solution, the film thickness can be optimized. The results of such coatings with a triple-layer ARC, DLARC, and SLARC demonstrated considerable improvement in the PCE by $39 \%, 32 \%$, and $27 \%$, respectively relative to bare Si solar cell having a PCE of $11.36 \%$. In other words, the PCE of the fabricated solar cell with triple-layer AR coating achieved an efficiency of $15.85 \%$ with a cost-effective methodology.

Research by $\mathrm{Xu}$ et al. provided insight about double-layer ARC on crystalline solar cells, and also their residual color was considered in this study. The coating consists of a dense silica layer at the bottom and a top mesoporous silica layer [264]. The fabricated DLAR coatings exhibited an average transmittance of about $99.02 \%$ in $380 \mathrm{~nm}$ to $780 \mathrm{~nm}$ wavelength range. When this coating is applied to the crystalline silicon module, a $2.40 \%$ increase in PCE is obtained in relative terms. Qiang-Ma et al. showed an optimum design of a quadruple-layer ARC structure for improving the PCE of c-Si cells [241]. The work involved coating three different ARCs on different c-Si cells and subsequent comparison of their performance. The first type coating includes a SiNx:H double-layer ARC, then the remaining two quadruple-layer ARC (QLARC) consists of $\mathrm{SiO}_{2}$ top layer which is deposited on two layers of $\mathrm{SiNx}: \mathrm{H}$ which in turn, is coated on $\mathrm{SiO}_{2}$ bottom layer in one case and $\mathrm{Al}_{2} \mathrm{O}_{3}$ bottom layer in the other case, constituting QLARC-1 and QLARC-2 coatings, respectively. The PCE is reported to be $14.25 \%, 14.43 \%$, and $10.93 \%$ for QLARC-1, QLARC-2, and DLARC, respectively. It is observed 
that the QLARC-2 structure has a slightly higher efficiency than the QLARC-1 structure, which can be explained by the higher index of refraction of the $\mathrm{Al}_{2} \mathrm{O}_{3}$ bottom layer when compared to the $\mathrm{SiO}_{2}$ layer providing a favorable condition for multilayer antireflective structures. Karthik et al. reported a low refractive index $\mathrm{MgF}_{2} \mathrm{ARC}$, on crystalline silicon solar cells prepared by the deformation-reformation route [186]. The coating exhibited a high transmission in the selected wavelength region, and the use of this coating on solar glass of c-Si cells had increased the efficiency of about $6 \%$.

Salman et al. fabricated $\mathrm{ZnO} /$ Porous silicon (PSi) layer ARCs for c-Si cells [236]. Generally, the integration of $\mathrm{ZnO}$ films with crystalline silicon is significant as it would induce stresses between the materials owing to the large mismatch in the coefficient of thermal expansion. Thus, an interesting case has been researched, and the ZnO/PSi layer ARC achieved an efficiency of $18.15 \%$. Also, Minemoto et al. succeeded in depositing ZnO thin films on spherical solar cells with a PCE of 11.8\% [265]. Gangopadhyay et al. used a nano-composite based antireflection coating to enhance the PCE of c-Si solar cells [266]. An attractive concept of wrinkle surface-based AR coating can successfully localize and trap the light. Also, large areas of wrinkles can be formed easily by cost-effective methods [267-269]. These are much suitable for polymer-based thin-film solar cells [270]. Polydimethylsiloxane (PDMS) is used for this purpose, and diverse PDMS wrinkle patterns have been reported [271-273]. The main advantage is that PDMS can be prepared by surface modification without using master molds [274,275]. Zhang et al. prepared a PDMS wrinkle film by surface modification aided by plasma treatment and demonstrated that the coating could improvise the efficiency in a relatively large incident angle. The average efficiency obtained was approximately $13.6 \%$ [211]. Basher et al. analyzed the impact of surface texturization in the photovoltaic performance of the monocrystalline Si solar cell. The group fabricated three PV samples, out of which the $\mathrm{Si}$ wafers of two samples are texturized with pyramidal structures using the wet-chemical texturization technique [276]. The textured substrates exhibited a $1.66 \%$ decrease in the optical reflectance, and the texturization improved the light-trapping ability, and the efficiency is almost twice that of the untextured solar cell.

\subsection{Multi-Crystalline Silicon Solar Cells}

In general, single crystalline silicon (sc-Si) solar cells can be textured easily by using an alkaline solution to texture a pyramidal structure that helps in absorbing more incident light [277]. But this is not effective in the case of multi-crystalline silicon (mc-Si) cells as it leads to randomly oriented grains [278]. Some studies suggest the application of RIE on both single crystalline and multi-crystalline silicon wafers that enhances the PCE of the solar cells together with silicon nitride ARCs [279-281]. Contrarily, plasma texturization paves a path for achieving isotropically texturized multi-crystalline silicon wafer, which cannot be achieved with conventional techniques adopted for crystalline silicon wafers. A study reported a considerable increase in PCE (20\%) of multi-crystalline Si cells through the development of the plasma texturization process [282]. An attempt by Prasad et al. using SiNx:H AR coating on mc-Si to obtain a low reflectivity. The performance of the cell demonstrated an improvement of nearly $2.4 \%$ in the efficiency of the large area $\left(149 \mathrm{~cm}^{2}\right) \mathrm{mc}-\mathrm{Si}$ cell [123]. Slooff et al. employed a polymer coating containing luminescent dye to improvise the efficiency of multi-crystalline solar cell [283].

Recently, $\mathrm{ZnO}$ nanostructures have been employed on various solar cells to impart AR properties (amorphous-Si [284,285], sc-Si [286-288], mc-Si [289], GaAs [290]). Lin et al. deposited syringe-shaped $\mathrm{ZnO}$ nanorods on multi-crystalline silicon photovoltaic cells by a two-step aqueous solution process and obtained an efficiency enhancement of nearly $41 \%$ with a value of $17.61 \%$ when compared to those of bare surface [172]. Also, the use of the $\mathrm{TiO}_{2}$ layer on mc-Si solar cells as an edge for improving the photovoltaic performance of the device [291,292]. Hocine et al. worked on $\mathrm{TiO}_{2}$ antireflection coating on mc-Si solar cell [147], which was deposited by using an atmospheric pressure CVD method (APCVD), a relatively low-cost technology compared to PECVD. The fabricated solar cell achieved a PCE of $14.26 \%$, with an enhancement of $3 \%$ compared to the reference cell. 


\subsection{Thin-Film Solar Cells}

The thin-film solar cells have gained significant attention in research due to their excellent solar conversion properties and possible realizations on numerous substrates, even including polymer substrates [293]. Singh et al. implemented SiNx as an index matching layer in a-Si thin-film solar cells [294]. The study claims to reduce the reflection loss by engineering the silicon nitride films between glass and TCO. The RI of the film is optimized in the range between that of glass and TCO. The fabricated cell exhibited a reduced reflectance of $8 \%$ when $\mathrm{SiNx}$ is utilized, and the current density is improved by $20 \%$. Another approach by Wang et al. used combined sol-gel obtained $\mathrm{SiO}_{2}$ and metal-organic CVD obtained Boron doped $\mathrm{ZnO}(\mathrm{BZO})$ thin films to enhance the efficiency of thin-film solar cells. The structure of the novel AR substrate is $\mathrm{SiO}_{2}$ film/glass/BZO. The coating exhibited high transmittance in the broad wavelength region of 350-1100 nm, and the performance of the coated a-Si thin solar cells is enhanced from 9.83\% to 10.24\% [104]. Similarly, Al-doped $\mathrm{ZnO}$ is considerable material that possesses good transparency, conductivity, and low-cost $[295,296]$. In line with it, Lu et al. investigated the effect of aluminum-doped $\mathrm{ZnO}$ as an AR coating in thin-film Si solar cells [297]. Yang et al. simulated a dual AR design with multiple layers coated on both the sides of the glass substrate, and the coated thin-film cell also possesses a back reflector. The optimized coating showed a very low reflectance of $2.58 \%$ in comparison with the ARCs on Si solar cells. Apart from it, omnidirectional and broadband performance is obtained, and the spectrum averaged external quantum efficiency accounts for $81.4 \%$ at an incidence angle of $75^{\circ}$ [298]. Textured glass substrates are highly suitable for Si thin-film PV technologies such as commercially available Asahi-U glass substrate. Addonizio et al. utilized aluminium induced texturization (AIT) method to fabricate a textured glass substrate for thin-film photovoltaic technology. The cell fabricated by the AIT method shows a higher quantum efficiency in the entire wavelength range considered, yielding a better antireflective property when compared to cell fabricated with Asahi-U substrate and flat glass substrate. Also, the obtained short circuit current density is $13.9 \mathrm{~mA} / \mathrm{cm}^{2}, 10.9 \mathrm{~mA} / \mathrm{cm}^{2}$, and $13.7 \mathrm{~mA} / \mathrm{cm}^{2}$ for the cell fabricated on the AIT textured glass, flat substrate, and Asahi-U glass substrate [299].

\subsection{Multi-Junction Solar Cells}

The stacking of III-IV compound semiconductors with different bandgaps using tunnel junction, which is also known as multi-junction solar cells, has the potential to extract more power from light per sq. area as compared to that of single-junction solar cells [300,301]. These highly efficient solar cells can remain effectual only by adopting proper antireflection coatings. Oh et al. prepared a broadband antireflection coating for InGaP/GaAs/InGaAsP/InGaAs multi-junction solar cells [302]. ZnS and $\mathrm{MgF}_{2}$ were used as antireflection coating materials that were deposited using the GLAD technique. As expected, the outcome of ARC deposited multi-junction solar cells showed an improvement in the PCE from $9.91 \%$ to $13.3 \%$. Tsai et al. fabricated a graded refractive index film with $\mathrm{ZnO}$ nanorods and $\mathrm{TiO}_{2}$ layer, which is deposited on InGaP/GaAs/Ge triple-junction solar cells to improve the omnidirectional photovoltaic performance [303]. The coating exhibited a weighted average reflectance of about $6 \%$ over the wavelength range $380-1800 \mathrm{~nm}$. Further, the coating is hydrophobic with $128.2^{\circ} \mathrm{WCA}$, and the enhancement of $31.8 \%$ in short circuit density is obtained for the fabricated solar cell with omnidirectional performance. Thus, the proposed GRIN ARC is more promising for the next generation of solar cells. GaInP/GaAs/Ge is a salient triple-junction solar cell, and various antireflection coatings have experimented. Leem et al. used a composite DLARC of $\mathrm{SiO}_{2} / \mathrm{TiO}_{2}$, and on depositing, the PCE was improved from $28.28 \%$ to $30.72 \%$ [304]. Hou et al. deposited two variants of ARC consisting of SLARC SiNx and $\mathrm{TiO}_{2} / \mathrm{Al}_{2} \mathrm{O}_{3}$ DLARC on the GaInP/GaAs/Ge multi-junction cell and the performance was improved from $23.45 \%$ to $27.17 \%$, and to $29.91 \%$ corresponding to SLARC and DLARC [305]. Another study by Sertel et al. analyzed the effect of $\mathrm{Ta}_{2} \mathrm{O}_{5}$ single-layer ARC and $\mathrm{SiO}_{2} / \mathrm{Ta}_{2} \mathrm{O}_{5}$ double-layer ARC on GaInP/GaAs/Ge triple-junction solar cell grown by Molecular beam epitaxy method. The fabricated SLARC exhibited a reduced average reflectance of $14 \%$, while the DLARC showed only $7 \%$ reflectance [306]. The effect of this low-reflectance is reflected in the 
performance of the triple-junction solar cell with an enhancement of $6 \%$ and $19 \%$ corresponding to SLARC and DLARC, respectively. This also raised the EQE and current density values in each sub-cell. Carbon nanotube - Silicon solar cells, and grapheme-Silicon solar cells are of great interest as they are emerging rapidly in the field of photovoltaics. Shi et al. fabricated a single layer graphene-silicon solar cells with colloidal AR coating of $\mathrm{TiO}_{2}$ material. The AR coating deposited on the prepared solar cell has improved the short circuit current density, and also, an enhancement of $14.5 \%$ in PCE is obtained [307]. Lancellotti et al. investigated the effects of different graphene chemical dopants on multi-layer graphene/n-Si solar cells with the $\mathrm{MgF}_{2} / \mathrm{ZnS}$ double layer antireflection coatings. The graphene chemical dopants utilized were nitric acid, and thionyl chloride and a DLARC is deposited on this Schottky barrier solar cell through thermal evaporation technique. In the case of $\mathrm{HNO}_{3}$ based doping, a $100 \%$ enhancement is obtained while $190 \%$ improvement is obtained in the case of $\mathrm{SOCl}_{2}$ when compared to pristine device. The implementation of $\mathrm{MgF}_{2} / \mathrm{ZnS}$ DLARC significantly improved the PCE and, the combined optimized doping and DLARC has resulted in a PCE of 8.5\% [308].

\subsection{Gallium Arsenide Based Solar Cells (GaAs)}

GaAs multijunction solar cells have been gaining attention consistently, which diluted the focus on single-junction GaAs solar cells [309]. ZnO is usually a preferred material, mainly because of its low cost, high-quality films, less toxicity, and its implementation is more straightforward [310-313]. Also, a single layer $\mathrm{ZnO}$ coating produces an equivalent enhancement of performance or even a cut above the multiple-layer coatings for GaAs and Silicon solar cells [314,315]. Makableh et al. reported an improvement in the performance of the GaAs cell by employing a Zinc oxide ARC deposited by the sol-gel technique. The enhancement achieved for the fabricated scheme was $32 \%$ in efficiency and $51 \%$ in quantum efficiency [170]. Jung et al. used the popular $\mathrm{MgF}_{2}$ single layer films on GaAs solar cells but also investigated the effects of $\mathrm{ZnS}-\mathrm{MgF}_{2}$ DLARC and $\mathrm{MgF}_{2} / \mathrm{ZnS}-\mathrm{MgF}_{2}$ multiple layer composite films which are deposited by using RF magnetron sputtering technique [316]. Low reflectance is obtained at a particular wavelength with the SLARC, while the suppression of reflection occurred in a wide wavelength when multilayer ARC is used combined with omnidirectional performance. Also, several other approaches to enhance the GaAs solar cell performance were made, such as texturization [317], the plasmonic effect $[318,319]$.

\subsection{Copper Indium Gallium Selenide Solar Cells (CIGS)}

Shim et al. fabricated an omnidirectional double-layer AR coating to enhance the PCE of CIGS solar cells. The coating consists of $\mathrm{ZnO}$ nanorods and $\mathrm{MgF}_{2}$ film, and the film exhibited high optical transmittance reducing the weighted global reflectance to about $5.5 \%$, and the power conversion efficiency was boosted by $17 \%$ [237]. Also, many studies focusing on $\mathrm{SiO}_{2}$-polymer based composite coatings fabricated by a single step sol-gel technique to achieve the gradient refractive index structure have potential in laser applications [320-323]. Related to this, a study by Li et al. employed polyethylene glycol (PEG) and polyvinyl pyrrolidone (PVP) additives in silica sols to obtain a modified $\mathrm{SiO}_{2}$-PEG and $\mathrm{SiO}_{2}$-PVP films using the sol-gel dip-coating technique. The study also investigated the coating's influence on the PCE of CIGS solar cells [245]. They achieved a very high transmittance, and the relative efficiencies of coated CIGS cells were improved by $7.27 \%$ and $8.33 \%$ for $\mathrm{SiO}_{2}-\mathrm{PEG}$ and $\mathrm{SiO}_{2}-\mathrm{PVP}$, respectively. Such modified $\mathrm{SiO}_{2}$ coatings possess advantages such as good adhesion, high antireflective performance, low-cost manufacturing. Shin et al. researched a novel moth-eye structured $\mathrm{ZnO}$ nanorod coatings as ARC on CIGS solar cells by a bottom-up process [188]. The bio-mimicked AR coating reduced the average reflectivity of CIGS solar cell from $6.14 \%$ to $1.46 \%$, and the PCE is enhanced from $10 \%$ to $11.5 \%$. Rezaei et al. simulated double-layer porous $\mathrm{MgF}_{2} \mathrm{ARC}$ using an effective medium approximation approach, and the study claims to shorten the simulation time from four days to one hour [324]. A 6.8\% enhancement is obtained in photocurrent density. Further, the study uses a point-contacted $\mathrm{MgF}_{2} / \mathrm{Al}_{2} \mathrm{O}_{3}$ reflector at the rear side of the cell, and with the combined effect of ARC, the photocurrent density is boosted up to $11.3 \%$ relative to the reference solar 
cell. Some studies impart texturization effects on the surface of $\mathrm{ZnO}: \mathrm{Al}$ to improve the performance of CIGS solar cells. For example, Dahan et al. obtained an improvement of $10 \%$ in the short circuit current density of CIGS solar cells from the theoretical and experimental point of view [325]. Another approach by Shimazaki et al. studied the effects of DLARC $\mathrm{SiO}_{2} / \mathrm{Al}_{2} \mathrm{O}_{3}$ deposited on the surface of $\mathrm{AZO}$, and as a result of which a $2.3 \%$ enhancement in short circuit current density is obtained [326]. In general, the research employing porous film on CIGS solar cells is reported only in a few studies. Wakefield et al. investigated the potential of mesoporous silica nanocomposite ARC for CIGS thin-film solar cells. Despite the vacuum deposition approach, the study incorporated wet deposition techniques to prepare a single layer of silica nanoparticle coating. The optimized coating exhibited a moderate reduction in reflection, and the short circuit current is increased by $4.9 \%$ on average [327]. Though it is a single layer coating, there is evidence that silica coatings improve the optical performance at high angles of incidence, which is significant for PV application [328,329].

\subsection{Dye-Sensitized Solar Cell (DSSC)}

DSSCs typically consists of a transparent conductive substrate, electrolyte, a working and counter electrode. They belong to the third generation of solar cells and have gained significant attention in the research field owing to their simple fabrication process and cost-effective production [330-332]. However, the efficiency of DSSCs is still lesser than that of commercial Si solar cells owing to high reflection loss, charge recombination, and power loss due to the resistance of the cell. Hence, there is no doubt that the incorporation of ARC in DSSC is advantageous in improving the PCE of the cell. In general, the $\mathrm{SiO}_{2}$ and $\mathrm{ZnO}$ thin films are deposited on the non-conductive surfaces of FTO in order to suppress the reflection. Chanta et al. improved the efficiency of DSSC from $1.19 \%$ to $1.54 \%$ by depositing a ZnO ARC on the FTO non-conducting surface, which resulted in higher light transmission when compared to reference film [333]. Also, Chen et al. fabricated silica ARC through a liquid phase deposition method and coated on the non-conducting surface of ITO by the action of which the transmittance is improved and thus, the efficiency was increased to $6.03 \%$ from $4.76 \%$ with a gain in the short circuit current density of $25.39 \%$ [334]. Li et al. employed DLARC consisting of $\mathrm{SiO}_{2}$ and $\mathrm{ZnO}$ films in which the $\mathrm{SiO}_{2}$ is deposited on the non-conductive surface of FTO by spraying method while $\mathrm{ZnO}$ film is fabricated by sol-gel methodology and deposited on the conductive surface of FTO. This $\mathrm{ZnO}$ layer also helps in restraining the charge recombination issues. The outcome was indeed favorable, with an increase in the current density from 10.79 to $12.90 \mathrm{~mA} / \mathrm{cm}^{2}$, and the PCE is enhanced from $4.67 \%$ to $5.79 \%$ [335]. A study reported the use of a double-layer $\mathrm{ZnO}$ ARC in which the bottom layer is RF sputtered, and the top layer is deposited by the sparking technique. The stacking of $\mathrm{ZnO}$ layers of different morphologies resulted in a short circuit current density of $5.80 \mathrm{~mA} / \mathrm{cm}^{2}$ and a maximum PCE of $1.88 \%$ owing to the improved transmission of light [336]. Li et al. fabricated a high-performance broadband AR and superhydrophobic coatings consisting of silica nanoparticles prepared by spin coating method, which is accompanied by calcination and hydrophobic modification. The obtained silica nanoparticles possess a porous structure that increased the roughness as well as the transmittance of the glass. In the wavelength range of 480-900 nm, the coating showed an absolute gain of $6 \%$ and a maximum transmittance of $99 \%$ at $580 \mathrm{~nm}$ wavelength. The obtained WCA was $147^{\circ}$ and the sliding angle was lesser than $10^{\circ}$. The effect of this coating on the performance of the DSSCs is reflected as a $10.12 \%$ improvement in the PCE, that is, an enhancement from 6.03 to $6.64 \%$ [337]. Titanium dioxide ARC is also researched and implemented on DSSCs. Kiema et al. deposited a porous $\mathrm{TiO}_{2}$ film by using oblique reactive e-beam evaporation technique. The best performing DSSC with annealed films exhibited a PCE of 4.1\% [80]. Lim et al., on the other hand, focuses on improving the efficiency of the DSSC through polymer AR coatings. A pattern of negatively tapered nanoholes on PDMS AR film is coated on the external surface of the glass. The optimized coating helps in improving the current density of DSSC from 15.69 to $16.52 \mathrm{~mA} / \mathrm{cm}^{2}$, and the PCE is enhanced by $7.56 \%$ relative to the reference cell [94]. 


\subsection{Organic Solar Cells (OSCs)}

Organic photovoltaics is one of the pioneering research field among the third-generation solar cells, which opened up broad applications in entirely different perspectives such as flexible solar cells, transparent solar cells, building-integrated photovoltaics. OSCs are unique owing to their low material cost, cost-effective processing methods, lightweight, high throughput, and compatibility with flexible substrates over a large area [338-340]. The PCE of the OSCs has been continuously improving, and the highest PCE attained has crossed 13\% [341]. Moreover, OSCs are thin and is a more promising candidate for further research. Focusing on ARC's influence on PCE, researchers have also contributed to this aspect. Dudem et al. reported an OSC with subwavelength architecture PDMS film as ARC, coated on a glass substrate, which enhanced both the transparency and the efficiency of the cell. The optimized SWA-PDMS on glass possessed a period of $125 \mathrm{~nm}$ and a diameter of $80 \mathrm{~nm}$. Consequently, the coating exhibited a maximum average transmittance of $\sim 95.2 \%$. On applying this coating on opaque and semi-transparent OSCs, the PCE was significantly enhanced from $8.67 \%$ and $7.07 \%$ to $10.59 \%$ and $8.52 \%$, respectively [209]. Leem et al. enhanced the efficiency of the OSC with the use of hydrophobic antireflective PDMS films. The PDMS film consists of a 2D periodic inverted moth-eye pattern on the surface is coated on the glass substrate, which is utilized in encapsulated OSC. The inverted moth-eye pattern is fabricated using soft imprint lithography. The optimized structures are reported to have a period of $380 \mathrm{~nm}$ that exhibited hydrophobic characteristics with a WCA of $\sim 120^{\circ}$. The solar weighted transmittance of the coating is $94.2 \%$, and the efficiency of the OSC is increased from $5.16 \%$ to $6.19 \%$ [18]. Another study by Kim et al. employed a $\mathrm{ZnO}$ nanorod array to enhance the efficiency of Bilayered Inverted OSCs. The periodically patterned $\mathrm{ZnO}$ nanorod array influenced the light-trapping ability of the solar cell, and the bilayer architecture in inverted OSC showed excellent stability combined with a maximum PCE of 5.95\% [155]. Leem et al. proposed a biomimetic moth-eye nanoarchitecture as a plasmonic structure to enhance the OSC's efficiency. This involves $\mathrm{ZnO}$ moth-eye structured nanoarchitecture that is grated as hexagonal periodic arrays on both the front and rear surface of the active layers [159]. Also, these structures are prepared by a cost-effective soft imprint nanopatterning technique. The ultimate enhancement in the PCE was $6.28 \%$, from $5.12 \%$ corresponding to the pristine device.

\subsection{Perovskite Solar Cells (PSCs)}

The perovskite solar cells (PSCs) are proven to be high-efficient solar cells [342] and typically use transparent conductive oxide (TCO) glasses like ITO and FTO. Usually, in the PSC devices, there is a trade-off between the optical transmittance and the sheet resistance of TCO meaning, the use of thick TCO can reduce the sheet resistance, but it affects the optical transmittance and this trade-off impacts the efficiency of PSCs. The antireflection coatings can aid in enhancing the light-harvesting property of the PSCs. Luo et al. fabricated an AR coating for perovskite solar cells based on silica nanospheres [119]. The coating is deposited using spin-coating techniques, and the microstructure and the thickness are regulated by adjusting the speed of the spin. The optimized ARC coating reduced the reflectance in a wide wavelength span, which boosted the efficiency from $14.81 \%$ as exhibited by reference PV cell to $15.82 \%$. An interesting study by Kim et al. demonstrates a novel self-cleaning antireflective coating composed of plasma-polymerized fluorocarbon (PPFC) on $\mathrm{Nb}_{2} \mathrm{O}_{5} / \mathrm{SiO}_{2} / \mathrm{Nb}_{2} \mathrm{O}_{5}$ (NSN) tri-layers deposited on PSC using a continuous roll-to-roll sputtering process [242]. The coating confirmed the self-cleaning and antireflective properties, and also the PCE of PPFC/NSN/HCPET/PSC was found to be $17 \%$. A study by Dudem et al. reported the potential of PDMS film as an ARC in perovskite solar cells. The PDMS layer possessed an inverted micro-pyramidal structure and is fabricated by a cost-effective and facile method of soft lithography via master mold having a micro-pyramidal structured Si. The transmittance is improved, and thus, the PCE of the reference cell, flat PDMS coated cell, and inverted pyramid structured PDMS coated cell were $17.17 \%, 17.42 \%$, and $17.74 \%$, respectively [192]. Further research is required to find suitable materials supporting antireflective properties for perovskite solar cell applications. 


\subsection{Heterojunction and Hybrid Solar Cells}

Heterojunction solar cells is a pioneering field of research in the photovoltaic industry owing to their characteristics such as higher efficiency [343,344], short processing time, low thermal budget, and when compared to diffused homojunction c-Si solar cells, the processing cost is low [345]. Similar to homojunction Si solar cells, the heterojunction solar cell also suffers from metallic shading losses and Fresnel reflection losses. Zhang et al. simulated and experimented with the effects of texturization on the heterojunction solar cells and also compared them with that of flat cells. Also, the usage of double-layer ARC (SiOx layer and ITO layer) plays a role in improving the efficiency of the cell by combined reduction of reflection loss and the parasitic absorption losses owing to the thinner ITO layer. Ultimately, the experimental observation shows that the textured heterojunction solar cell with DLARC has a short circuit current density of $40.5 \mathrm{~mA} / \mathrm{cm}^{2}$ and a PCE of $19.0 \%$ [346]. Hussain et al. employed $\mathrm{ZnO}$ as an active n-layer and also as an ARC for Si-based heterojunction solar cells. This approach can save the cost and complexity as the $\mathrm{ZnO}$ layer acts as both front n-layer and ARC. The optimized simulation results yielded a 19\% PCE with a fill factor of $81 \%$ [347]. Sachchidanand et al. investigated the combined role of metal nanoparticles and nanopyramid array in improving the light-trapping ability of the poly(3,4-ethylenedioxythiophene) polystyrene sulfonate (PEDOT:PSS)/c-Si nanopyramid based hybrid solar cells. By using a 3D finite-difference time-domain method, the enhancements are simulated. With the top nanopyramid textured arrays, the maximum current density was $35.91 \mathrm{~mA} / \mathrm{cm}^{2}$ while when combined with the effect of insertion of $\mathrm{Al}$ metal nanoparticles at the rear side of the hybrid solar cell, the current density increased to $41.71 \mathrm{~mA} / \mathrm{cm}^{2}$ which is $44.47 \%$ improvement relative to the planar hybrid cell [348].

\subsection{Other Types of Solar Cell}

Apart from the solar cells discussed in the above subsection, some novel and non-Si solar cells are grouped here as only a few research works in these classes of solar cells deal with performance enhancement by means of implementing antireflection coatings. These solar cells primarily include CdTe solar cells, quantum dots solar cells, Tandem solar cells, and concentrated photovoltaics. Concerning CdTe cells, Hu et al. fabricated silica thin film and layers of $\mathrm{SiO}_{2}$ nanoparticles through a sol-gel method, which is deposited on the glass substrate of CdTe solar cell [349]. The resultant coating exhibited a transmittance of $98 \%$ at $390-870 \mathrm{~nm}$ wavelength range with WCA of $97^{\circ}$ meaning, the coating possesses hydrophobic nature and also, the damp heat test, Light-tact, and ultraviolet radiation test imply good stability of the fabricated coatings. Womack et al. stacked layers of silica and zirconia films which are deposited using reactive magnetron sputtering. The enhancement in the short circuit current density was $0.65 \mathrm{~mA} / \mathrm{cm}^{2}$, and the PCE is improved by $3.6 \%$ relative to the reference cell [350]. Quantum dot solar cells (QDSCs) is an emerging candidate in the third generation of solar cells. Some unique qualities of QDSCs are tunable bandgaps, high absorption coefficients, and multiple exciton effects [351,352]. Lay et al. fabricated an innovative InGaAs quantum dots-in-a-well solar cells which exhibited a short-circuit current density of $17.4 \mathrm{~mA} / \mathrm{cm}^{2}$, and the PCE of $8.7 \%$. The solar cell is then coated with $\mathrm{Al}_{2} \mathrm{O}_{3} / \mathrm{HfO}_{2} \mathrm{ARC}$, and as a result, the performance is further improved, having a current density of $23.5 \mathrm{~mA} / \mathrm{cm}^{2}$, and the PCE is enhanced to $11.8 \%$ [353]. Implementation of ARC in a tandem solar cell is a challenging process. However, Zhang et al. successfully employed a hybridized hollow silica nanosphere coating as ARC either on one side or both the sides of glass superstrates of tandem solar cells. The ARC deposited on both sides demonstrated the largest enhancement in the current densities, which accounts for $4.20 \%$ and $7.53 \%$ for top and bottom subcells, respectively [354]. Considering CPV application, the ARC should possess broadband high-performance antireflection properties approximately covering 300-2000 nm wavelength range. Agustín-Sáenz et al. employed methyl-silylated silica coatings as ARC, and it exhibited great stability, hydrophobicity, high optical performance in broad wavelength range $[107,355]$. The plasmonic solar cells are detailed in Section 8.1. The most common antireflection coatings on the PV cell and its influence on PCE are represented in Table 7. 
Table 7. Antireflection coatings on PV cell.

\begin{tabular}{|c|c|c|c|c|}
\hline Type of PV Cell & AR Coating Material & Fabrication Technology & PCE (\%) & Reference \\
\hline Mono-crystalline solar cells & $\mathrm{ZnS}$ & Chemical bath deposition & $13.80 \%$ & [262] \\
\hline Mono-crystalline solar cells & $\begin{array}{l}\mathrm{SiO}_{2} / \mathrm{SiO}_{2}-\mathrm{TiO}_{2} / \mathrm{TiO}_{2} \text { triple-layer } \\
\text { ARC }\end{array}$ & Sol-gel method & $39 \%$ improvement & [216] \\
\hline Crystalline solar cells & Mesoporous DLAR silica & Sol-gel & 2.40 times increase & [264] \\
\hline Crystalline silicon solar cells & $\begin{array}{ll}\text { (i) } & \text { SiNx:H double layer } \\
\text { (ii) } & \text { SiNx:H and } \mathrm{SiO}_{2} \\
& \text { quadruple layer } \\
\text { (iii) } & \mathrm{SiNx}: \mathrm{H}, \mathrm{SiO}_{2} \text { and } \mathrm{Al}_{2} \mathrm{O}_{3} \\
& \text { quadruple layer }\end{array}$ & $\begin{array}{l}\text { DC reactive magnetron sputerring } \\
\text { and PECVD }\end{array}$ & $\begin{array}{ll}\text { (i) } & 10.93 \% \\
\text { (ii) } & 14.25 \% \\
\text { (iii) } & 14.43 \%\end{array}$ & [241] \\
\hline Crystalline silicon solar cells & Polydimethylsiloxane (PDMS) & $\begin{array}{l}\text { Ion-beam etching and plasma } \\
\text { treatment }\end{array}$ & $13.60 \%$ & [211] \\
\hline Crystalline silicon solar cells & $\mathrm{MgF}_{2}$ & Deformation-reformation approach & $6 \%$ improvement & [186] \\
\hline Crystalline silicon solar cells & $\mathrm{ZnO} / \mathrm{PS}$ layers & $\begin{array}{l}\text { Photoelectrochemical etching and } \\
\text { radio frequency sputtering method }\end{array}$ & $18.15 \%$ & [236] \\
\hline Multi-crystalline silicon solar cells & $\mathrm{ZnO}$ nanorod arrays & Two-step aqueous solution method & enhancement of $41 \%$ & [172] \\
\hline Multi-crystalline silicon solar cells & $\mathrm{TiO}_{2}$ & $\begin{array}{l}\text { Atmospheric pressure chemical } \\
\text { vapor deposition }\end{array}$ & increased from $11.24 \%$ to $14.26 \%$ & [147] \\
\hline Multi-crystalline silicon solar cells & Silicon nitride & $\begin{array}{l}\text { Plasma texturization and chemical } \\
\text { etching }\end{array}$ & improvement up to $\sim 2.4 \%$ & [123] \\
\hline $\begin{array}{l}\text { Thin film solar cells } \\
\text { Multi-junction solar cells }\end{array}$ & $\begin{array}{l}\mathrm{SiO}_{2} \text { and } \mathrm{BZO} \\
\mathrm{ZnS} \text { and } \mathrm{MgF}_{2}\end{array}$ & $\begin{array}{l}\text { Sol-gel and MOCVD method } \\
\text { Glancing angle deposition }\end{array}$ & $\begin{array}{l}\text { Enhanced from } 9.83 \% \text { to } 10.24 \% \\
\text { improved from } 9.91 \% \text { to } 13.3 \%\end{array}$ & $\begin{array}{l}{[104]} \\
{[302]}\end{array}$ \\
\hline Multi-junction solar cells & $\begin{array}{l}\text { (i) } \mathrm{Ta}_{2} \mathrm{O}_{5} \text { SLARC } \\
\text { (ii) } \mathrm{SiO}_{2} / \mathrm{Ta}_{2} \mathrm{O}_{5} \text { DLARC }\end{array}$ & Molecular beam epitaxy method & $\begin{array}{l}\text { enhancement of (i) } 6 \% \text { and (ii) } \\
19 \%\end{array}$ & [306] \\
\hline GaAs p-n junction solar cell & $\mathrm{ZnO}$ & Sol-gel method & $32 \%$ enhancement & [170] \\
\hline CiGS solar cells & $\mathrm{MgF}_{2}$ and $\mathrm{ZnO}$ & $\begin{array}{l}\text { RF sputtering and hydrothermal } \\
\text { method }\end{array}$ & boosted by $17 \%$ & [237] \\
\hline
\end{tabular}


Table 7. Cont.

\begin{tabular}{|c|c|c|c|c|}
\hline Type of PV Cell & AR Coating Material & Fabrication Technology & PCE (\%) & Reference \\
\hline CiGS solar cells & $\begin{array}{l}\text { (a) } \mathrm{SiO}_{2} \text {-Polyethylene glycol } \\
\text { (PEG) } \\
\text { (b) } \mathrm{SiO}_{2} \text { polyvinyl pyrrolidone } \\
\text { (PVP) }\end{array}$ & Sol-gel dip coating process & $\begin{array}{l}\text { (a) increased by } 7.27 \% \\
\text { (b) increased by } 8.33 \%\end{array}$ & [245] \\
\hline CiGS solar cells & $\mathrm{SiO}_{2}$ & $\begin{array}{l}\text { Sol-gel dip-coating and electrostatic } \\
\text { self-assembly technique }\end{array}$ & increased from $11.66 \%$ to $12.59 \%$ & [120] \\
\hline CiGS solar cells & $\mathrm{ZnO}$ nanorods & Aqueous solution method & increased from $10 \%$ to $11.5 \%$ & [188] \\
\hline DSSC & Silica & Liquid phase deposition & increased from $4.76 \%$ to $6.03 \%$ & [334] \\
\hline DSSC & $\mathrm{SiO}_{2}$ and $\mathrm{ZnO}$ & Sol-gel and spraying technique & enhanced from $4.67 \%$ to $5.79 \%$ & [335] \\
\hline Organic solar cells & PDMS film & Soft imprint lithography & increased from $5.16 \%$ to $6.19 \%$ & [18] \\
\hline Organic solar cells & $\mathrm{ZnO}$ moth-eye structure & Soft imprint nanopatterning & enhanced from $5.12 \%$ to $6.28 \%$ & [159] \\
\hline Perovskite solar cells & PPFC and NSN & $\begin{array}{l}\text { Roll to roll sputtering and plasma } \\
\text { treatment }\end{array}$ & $17 \%$ & [242] \\
\hline Perovskite solar cells & Silica & Spin coating & Increased from $14.81 \%$ to $15.82 \%$ & [119] \\
\hline
\end{tabular}




\section{Advanced Light-Trapping Techniques}

Enhancing the conversion efficiency in the solar PV cells requires improved transmittance of light from the ambient to the active PV material and subsequent absorption of photons by the active material. Moreover, the spectral sensitivity of the commonly used active material (Silicon) is effective only within the visible range, which results in significant loss of available energy before photovoltaic conversion. To resolve this problem, some novel strategies such as the plasmonic assisted absorption enhancement, spectral modification techniques, and other innovative light-trapping structures can be implemented to enhance the absorption. An insight into these strategies is provided in this section.

\subsection{Plasmonic Structures}

The concept of plasmonic in confining or directing the light at the metal-dielectric interface has vast potential to trap the light in the solar cells. This novel method makes use of metal nanoparticles that supports surface plasmons (excitations of conduction electrons at the interference of metal and a dielectric medium). By the proper incorporation of metal nanostructures in the solar cell, the light can be directed or concentrated in the active material to maximize the absorption [356]. Plasmonic structures have been reported in at least three different configurations, which include plasmonic structures deposited on the surface of the cell, structures embedded into the active layer of the cell, and structures at the interface between the semiconductor and the metal electrode [357]. The various configuration is illustrated in Figure 27.
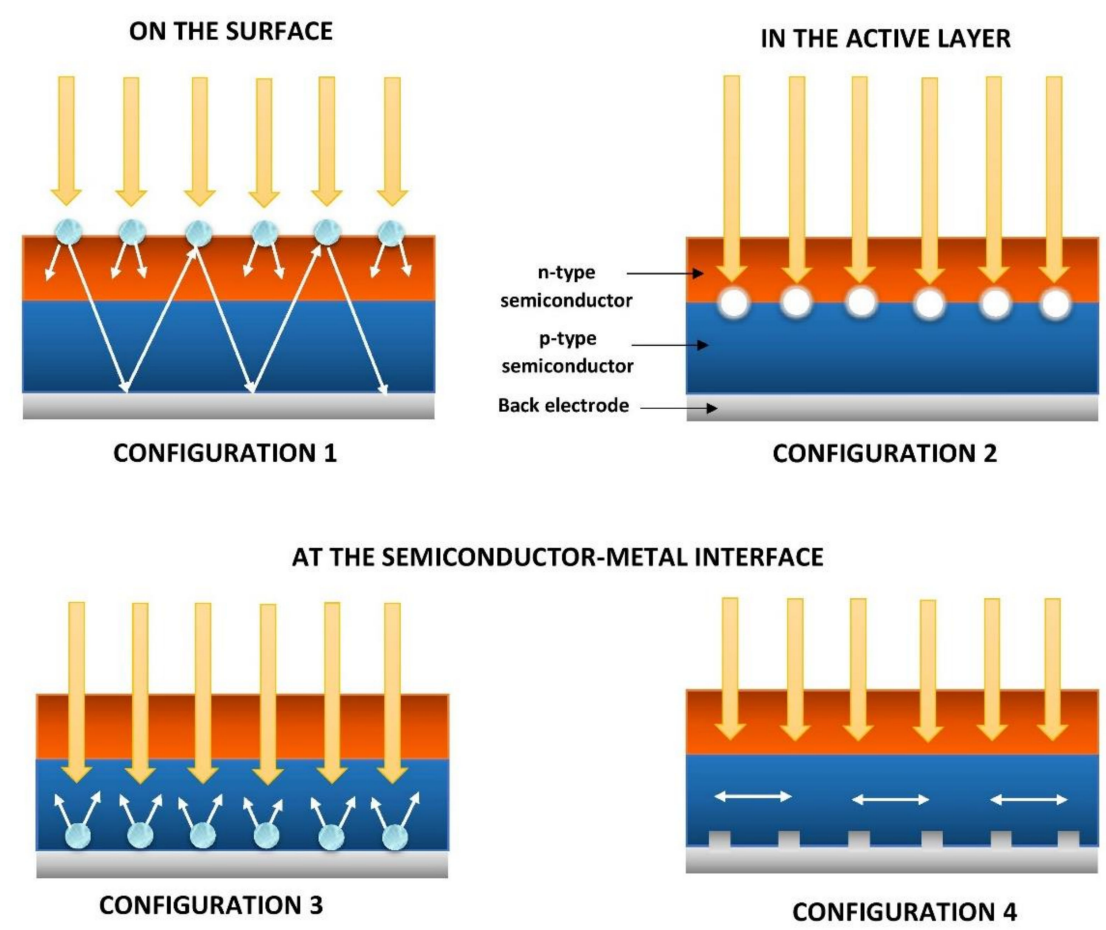

Figure 27. Various light-trapping configurations for plasmonic assisted solar cells.

The various configuration makes use of different optical phenomenon to achieve light trapping ability. In the first configuration, the light is scattered by the metal nanoparticles at high angles and are trapped and dispersed in the semiconductor film. This results in an increased effective optical path length inside the cell and thus enhancing the light absorption. The second configuration makes use of the strong localized field around the excited metal nanoparticles to improve the light-absorbing ability of the semiconductor. The third configuration improves the optical path length by back-scattering the incident light back to the substrate. In the fourth configuration, light is trapped by the excitation of surface plasmon polaritons, and the light is propagated along with the interface in the semiconductor 
plane. In this configuration, a metal grating consisting of periodically arranged nanostructure placed at the interface of semiconductor and metal is used.

Apart from the configurations, it is also reported that the shape and size of the metal nanoparticles also have a significant impact on the in-coupling efficiency $[358,359]$. Simulations by Catchpole and Polman give a clear understanding of the influence of various shape and size of nanoparticles employed [358]. In short, the cylinder and the hemispherical shape resulted in higher optical pathlengths than the spherical shape. From observation, it is also seen that the smaller the size, the better is the forward scattering of light, but very small structures would suffer from significant ohmic losses. Further, from the material aspects, they employed gold and silver nanoparticles, out of which Ag provided increased optical pathlengths than Au for the same dimension.

Various materials have been reported in plasmonic enhanced solar cells such as silver, gold, titanium dioxide, aluminum, and so on. Matheu et al. investigated the electromagnetic scattering of $\mathrm{Au}$ and silica nanoparticles positioned at the top of the silicon PV device and their influence on the photocurrent generation [360]. The diameter of the gold and silica nanoparticles fabricated were $100 \mathrm{~nm}$ and $150 \mathrm{~nm}$, respectively. The scattering effects of the nanoparticles have enhanced the photocurrent by $2.8 \%$ for Au nanoparticles and $8.8 \%$ for silica nanoparticles in silicon PV cells. Zhang et al. analyzed the effect of surface plasmon resonance in enhancing the optical absorption in thin Si solar cells [361]. The group employed aluminum nanoparticles and examined the influence of particle size and the space between the particles in improvising the optical path length. The simulation showed a maximum enhancement of $40 \%$ in absorption for incorporating aluminum nanoparticles of diameter $100 \mathrm{~nm}$ with a period of $150 \mathrm{~nm}$. Zhang et al. experimented and simulated the influence of incorporated $\mathrm{Al}$ nanoparticles together with the deposited AR coating on multi-crystalline silicon solar cells [362]. An averaged diameter of $100 \mathrm{~nm} \mathrm{Al}$ nanoparticles is used, and the enhancement in photocurrent generation of $0.4 \mathrm{~mA} / \mathrm{cm}^{2}$ is obtained, which boosted the power conversion efficiency of industrial standard textured multi-crystalline Si solar cell from $14.2 \%$ to $14.5 \%$. This study shows that the light trapping ability influenced by the different mechanisms (for ARC and plasmonic structures) can be combined on a single device to obtain substantial enhancements. Such devices would provide a low-cost solution with the use of abundant materials like aluminum and silicon-based materials.

The prospects of absorption enhancements due to a near-field plasmonic effect in the semiconductor are enormous. Spinelli and Polman incorporated silver nanoparticles in the semiconductor materials and analyzed the light interaction and absorption enhancements through simulations [363]. The absorption enhancements are analyzed for Ag nanoparticles with diameters ranging from 5 to $60 \mathrm{~nm}$ for crystalline silicon, amorphous silicon, polymer blends, and $\mathrm{Fe}_{2} \mathrm{O}_{3}$. The absorption was significantly affected by the ohmic losses in all the cases. The result showed nearly a $20 \%$ absorbance enhancement in crystalline $\mathrm{Si}$, and $24 \%$ enhancement is seen in $\mathrm{Fe}_{2} \mathrm{O}_{3}$. A $100 \mathrm{~nm}$ thick polymer blend layer yielded an enhancement in absorption from $17 \%$ to $34 \%$ over the wavelength range of 300-1100 nm. Another study by Wang et al. demonstrates the importance of optimizing the reflectors in the case of using grating structures at the rear surface of the semiconductor [364]. The simulations investigated the light trapping properties of the 2D diffraction grating formed by silver discs or $\mathrm{TiO}_{2}$ pillars, which is positioned at the solar cell rear surface. By optimizing the grating dimensions and the distance from the reflectors, the short circuit current enhancements of about $67 \%$ and $45 \%$ were obtained for silver and $\mathrm{TiO}_{2}$ nanoparticles, respectively. Prabhathan and Murukeshan proposed a surface plasmon polariton (SPP) waveguide coupled with back reflector. They employed an aluminum thin metal layer as SPP grating in the simulation and obtained optimized dimensions for the metal layer and the back-reflector distance that yielded maximum enhancements [365]. The maximum absorption enhancement of $153 \%$ is obtained for thin-film silicon solar cell with a silicon substrate thickness of $220 \mathrm{~nm}$ with $20 \mathrm{~nm}$ thickness of the SPP thin metal layer and at a $30 \mathrm{~nm}$ distance from back metal. The crux of some simulation-based and experimental-based work on plasmonic enhanced solar cells have been described in Table 8 in which the various work has been categorized based on the configuration used (configuration 1-4 shown in Figure 27). 
Table 8. Various plasmonic enhanced solar cells with different light trapping configurations.

\begin{tabular}{|c|c|c|c|c|c|c|c|}
\hline Configuration & Material & Substrate & $\begin{array}{c}\text { Material } \\
\text { Structures }\end{array}$ & Dimensions & Category & Results & Reference \\
\hline \multirow{4}{*}{1} & $\begin{array}{c}\mathrm{Ag} \text { and } \mathrm{Au} \\
\text { nanoparticles }\end{array}$ & Silicon & $\begin{array}{c}\text { Cylinder } \\
\text { Hemispherical } \\
\text { Spherical }\end{array}$ & $\begin{array}{c}\mathrm{d}=100 \mathrm{~nm}, \mathrm{~h}=50 \mathrm{~nm} \\
\mathrm{~d}=100 \mathrm{~nm} \\
\mathrm{~d}=100 \mathrm{~nm} \& 150 \mathrm{~nm}\end{array}$ & Simulations & $\begin{array}{l}\text { Cylindrical and hemispherical shapes exhibited } \\
\text { improved path lengths than spherical shaped particles. } \\
\text { Also, Ag particles provide better path length } \\
\text { enhancements than Au particles }\end{array}$ & [358] \\
\hline & $\begin{array}{l}\text { Au and silica } \\
\text { nanoparticles }\end{array}$ & Silicon & - & $\begin{array}{c}\text { Au-d }=100 \mathrm{~nm} \\
\text { Silica-d }=150 \mathrm{~nm}\end{array}$ & $\begin{array}{c}\text { Simulation and } \\
\text { experiment }\end{array}$ & $\begin{array}{l}\text { Photocurrent enhancement of } 2.8 \% \text { and } 8.8 \% \text { in } \\
\text { crystalline Si PV were obtained for Au and silica } \\
\text { nanoparticles, respectively }\end{array}$ & {$[360]$} \\
\hline & $\begin{array}{l}\text { Aluminum } \\
\text { nanoparticles }\end{array}$ & Silicon & Spherical & $\mathrm{d}=100 \pm 30 \mathrm{~nm}$ & $\begin{array}{c}\text { Simulation and } \\
\text { experiment }\end{array}$ & $\begin{array}{l}\text { Photocurrent improvement of } 0.4 \mathrm{~mA} / \mathrm{cm}^{2} \text { was achieved } \\
\text { due to the incorporation of Al nanoparticles in SiNx AR } \\
\text { coatings deposited on textured multi-crystalline Si solar } \\
\text { cells }\end{array}$ & [362] \\
\hline & $\begin{array}{l}\text { Aluminum } \\
\text { nanoparticles }\end{array}$ & Silicon & - & $\begin{array}{l}\mathrm{d}=\text { Varied from } 60 \text { to } \\
\quad 220 \mathrm{~nm}\end{array}$ & Simulation & $\begin{array}{l}\text { The enhancement factor increase as the size of } \\
\text { nanoparticles increases up to } 100 \mathrm{~nm} \text {. Maximum } \\
\text { absorption enhancement of } 40 \% \text { is obtained for } \mathrm{Al} \\
\text { nanoparticles with } \mathrm{d}=100 \mathrm{~nm} \text { and } 150 \mathrm{~nm} \text { period }\end{array}$ & [361] \\
\hline 2 & Ag nanoparticles & $\begin{array}{l}\text { Crystalline } \mathrm{Si}, \\
\text { amorphous } \mathrm{Si}, \\
\text { polymer blend and } \\
\mathrm{Fe}_{2} \mathrm{O}_{3}\end{array}$ & - & $\mathrm{d}=5$ to $60 \mathrm{~nm}$ & Simulation & $\begin{array}{l}\text { Significant Ohmic losses in the metal dominate the } \\
\text { absorption in c-Si, a-Si, } \mathrm{Fe}_{2} \mathrm{O}_{3} \text {, and polymer blend. } \\
5 \text {-fold enhancement in c-Si while a-Si cannot be } \\
\text { sensitized. Absorption can be enhanced by } 17-34 \% \text { in } \\
\text { the polymer blend }\end{array}$ & [363] \\
\hline \multirow[t]{2}{*}{3} & $\mathrm{Ag}$ and $\mathrm{TiO}_{2}$ & Silicon & $\begin{array}{l}\text { Silver discs and } \\
\text { titanium dioxide } \\
\text { pillars }\end{array}$ & $\begin{array}{c}\mathrm{Ag}-\mathrm{d}=200 \mathrm{~nm} \\
\mathrm{~h}=50 \mathrm{~nm} \\
\mathrm{TiO}_{2}-\mathrm{d}=400 \mathrm{~nm} \\
\mathrm{~h}=300 \mathrm{~nm}\end{array}$ & Simulation & $\begin{array}{l}\text { Enhancement of short circuit current of about } 67 \% \text { and } \\
45 \% \text { for silver and } \mathrm{TiO}_{2} \text { nanoparticles, respectively }\end{array}$ & [364] \\
\hline & $\mathrm{Au}$ & Silicon & $\begin{array}{l}\text { Spherical gold } \\
\text { nano colloids }\end{array}$ & $\begin{array}{c}\mathrm{d}=100,150 \text { and } \\
200 \mathrm{~nm}\end{array}$ & Experiment & $\begin{array}{l}\text { Superior enhancements of photocurrent are obtained by } \\
\text { incorporating plasmonic back reflectors with } 150 \text { and } \\
200 \mathrm{~nm} \text { Au metal nanoparticle }\end{array}$ & [367] \\
\hline 4 & Aluminum & Silicon & $\begin{array}{l}\text { Thin metal layer } \\
\text { (SPP grating) }\end{array}$ & $\begin{array}{c}\text { Thickness }=20 \mathrm{~nm} \\
\text { Length }=1.5 \mu \mathrm{m} \\
\text { Spacing }=100 \mathrm{~nm} \\
\text { Distance from back } \\
\text { metal }=30 \mathrm{~nm} \\
\text { Silicon substrate } \\
\text { thickness }=220 \mathrm{~nm}\end{array}$ & Simulation & $\begin{array}{l}\text { Improvement in the absorption for an ultrathin Si solar } \\
\text { cell is about } 153 \% \text { in the wavelength range of } 400-1100 \\
\mathrm{~nm}\end{array}$ & [365] \\
\hline
\end{tabular}

at the semiconductor- metal interface, Configuration 4-SPP grating structures at the semiconductor- metal interface. 
The main advantage of incorporating the plasmonics in the solar cell is seen as a reduction in the thickness of the silicon substrate for a given optical absorption. Thin-film solar cells are economical, but they poorly absorb the light as the substrate is thin. In such applications, plasmonics can play a more prominent role and improve their light-absorbing ability. Many designs have been proposed for attaining plasmonic enhanced solar cells, and the usage of abundant material like aluminum and silica nanoparticles have the potential to enhance the light absorption in solar cells with low-cost investment. Also, they can be coupled with antireflective coatings to boost the efficiency of the solar cells further.

\subsection{Spectral Modification}

Generally, silicon solar cells work effectively on a narrow wavelength range (in the visible range), and only photons having appropriate energy can support the photovoltaic conversion. Thus, the photons having lesser energy cannot promote the electrons to the conduction band, and this insufficient excitation energy is thermalized. Also, the photons having higher energy than required, promote the electrons to the conduction band, and the remaining energy is converted into heat energy. This generated heat raises the device temperature, and in turn, decreases the power conversion efficiency. Thus, concepts of spectral modification are developed to encounter this issue by converting the photons of higher energies and lower energies into the desired levels of energy. By doing so, the efficiency of the cell is enhanced as well as the heat generation is minimized. There are mainly three methods for accomplishing spectral modification that includes photoluminescence (PL), down-conversion (DC), up-conversion (UC) techniques. The down-conversion and photoluminescence techniques convert the higher energy short-wavelength photons (typically 350-550 $\mathrm{nm}$ ) into lower energy longer wavelength photons (typically $500-1000 \mathrm{~nm}$ ) while the up-conversion technique transforms the lower energy photons to the higher energy photons [368]. Technically, the transparent host material is imparted with active ions, which absorbs the incident light and gains the excitation energy. In the case of photoluminescence and down-conversion, the de-excitation of this active ions occurs in two stages, with the only difference that in PL, the first de-excitation is non-radiative one and the following second stage relaxation involves radiative photon emission while in DC, both the stages of de-excitation involve radiative emission. The up-conversion technique, on the other hand, occurs by the sequential absorption of two photons of lower energy and the emission of single high energy photon. The illustration of the process is represented in Figure 28.

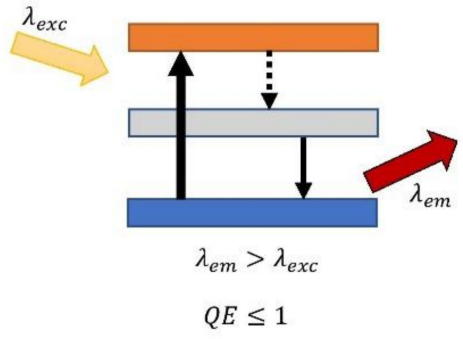

(a) Photoluminescence

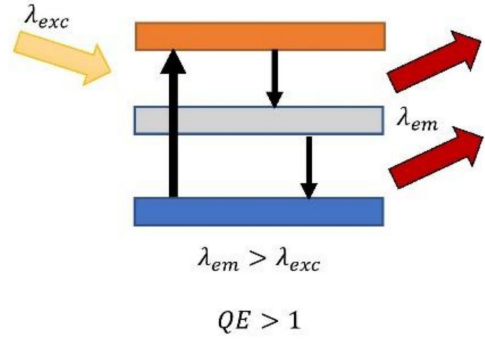

(b) Down-conversion

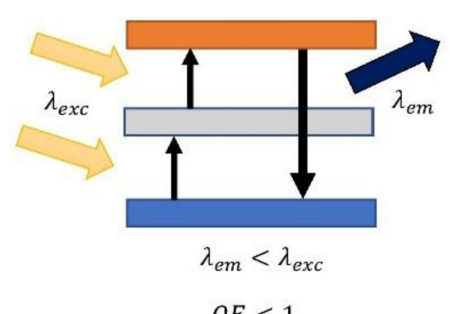

(c) Up-conversion

Figure 28. Schematic illustration of various spectral modification methods.

The quantum efficiency $(\mathrm{QE})$ is the ratio of the number of the photons emitted to the number of incident photons absorbed. Since the DC technique involves the absorption of single high energy photons and the emission of two low energy photons, the quantum efficiency of DC exceeds $100 \%$, whereas the PL technique would have a QE lesser than or equal to $100 \%$. The down-conversion technique, also regarded as quantum cutting, is usually attained by doping active ions of divalent or trivalent lanthanide elements into the transparent host material [369-371]. These lanthanide ions have abundant active states owing to the atomic structure that allows them to absorb light and emit photons at the broad spectrum from UV to IR [372,373]. This technique can effectively reduce 
the thermalization losses contributed by the high energy photons and also assist in increasing the photocurrent generation. Svrcek et al. employed silicon nanocrystals for effective down-conversion from blue photons (nearly $450 \mathrm{~nm}$ ) to red photons (about $680 \mathrm{~nm}$ ) to enhance the organic and hybrid organic/inorganic heterojunction solar cell [374]. By implementing the DC spectral modification, the photocurrent under concentrated sunlight was enhanced by $24 \%$. Fukuda et al. utilized wavelength conversion film (WCF) that consists of Eu chelate particles encapsulated in silica glass obtained from the sol-gel process. The Eu chelate excitation spectrum demonstrated that the violet light below $400 \mathrm{~nm}$ is converted into red light of $613 \mathrm{~nm}$ [375]. Moreover, the PV cells possess higher sensitivity towards red light than compared to violet light, which makes the Eu chelate more appealing for photovoltaic applications.

The upconversion technique can be used to match the lower energy portion of the solar spectrum to the effective absorption spectral range of the solar cells. The quantum efficiency of UC technique lies well below $100 \%$ as two photons of lower energy is absorbed to yield a single high energy photon. Similar to down-conversion techniques, nanoparticles of lanthanide series (rare earth elements) is used to dope the host material [368]. Chen et al. employed lanthanide-doped nano-phosphors as UC-converters to harvest sub-bandgap photons for organic solar cells [376]. An improvement in the short circuit current in the UC film deposited device was found to be $1.6 \%$ under one sun irradiation. Many materials have been experimentally researched for up-conversion techniques, and there is no significant improvement in PCE of the solar cells under AM1.5 solar conditions. Also, other considerations of implementing hybrid light trapping techniques such as ARCs and spectral matching on a single device are of great interest. A detailed investigation of spectral modification techniques is provided in referred studies $[368,377]$.

\subsection{Potential Light Trapping Structures}

It is pivotal to improve the optical absorption of silicon solar cells by increasing the optical path length. This will result in thin silicon solar cells that ultimately help in reducing the cost. Although the implementation of AR coating film and texturization on the front side significantly reduces the reflection losses, there is still some part of the light that passes through the cell without absorbing photovoltaic conversion. Hence, broadband absorption enhancement is another potential area in which PV efficiency can be substantially improved. From the theoretical aspects, Yablonovitch proposed a thermodynamic limit using a statistical ray optics approach, which implicit the minimum thickness needed for complete absorption of the solar spectrum or maximum light absorption a homogeneous absorber material can obtain for a given thickness [378]. Researchers have been simulating and experimenting with nanophotonic structures and other innovative textured surfaces to attain this limit. This section would provide an insight into some innovative structures that enhanced the absorption and nearly attained or conquered the Yablonovitch limit.

The pyramidal texturization effectively suppresses the reflection taking place at the top surface due to the so-called "double bounce effect" [379,380]. In recent studies, it is seen that ultrathin silicon cells with double-sided texturization have been proven effective in simulations [381-383], and also experimental analysis of double-sided pyramids provided superior results in crystalline Si solar cells $[384,385]$. Guan et al. designed and simulated an ultrathin crystalline silicon solar cells with front and double-sided pyramids. By optimizing the pyramid shape, the maximum photocurrent density of front pyramids and double-sided pyramids is found to be $36.23 \mathrm{~mA} / \mathrm{cm}^{2}$ and $37.71 \mathrm{~mA} / \mathrm{cm}^{2}$, respectively [386]. The double-sided pyramidal structures not only suppresses the reflection, but also improves the optical absorption at long wavelength range that made the absorption to reach the Yablonovitch limit. The calculated PCE for plane solar cell, front pyramidal, and double-sided pyramidal textured cells are found to be $16.94 \%, 19.65 \%$, and $20.45 \%$, respectively. Wangyang et al. characterized silicon square nano-conical frustum (SiSNF) arrays for PV application through simulation. The solar cells based on the optimized SiSNF yielded an ultimate efficiency of $31.60 \%$, which is $3.47 \%$ higher than that of silicon hexagonal nano-conical frustum (SiHNF) arrays of textured surface-based solar cells, 
which is close to perfect Yablonovitch surface [387]. Also, it is observed that efficiency is unaffected by the incident angles and top diameter. Another study by Ma et al. also focusses on the efficient enhancement of ultrathin c-Si solar cells by using composite grating structures [383]. The group utilized three-dimensional, rigorous coupled-wave analysis to investigate the light absorption characteristics of the used composite grating structures, and it is observed that the light absorption approached the Yablonovitch limit in both IR and visual regions of the spectrum. The photocurrent density of the optimized structure is $33.9 \mathrm{~mA} / \mathrm{cm}^{2}$ at $2 \mu \mathrm{m}$ equivalent thickness.

Some studies have also claimed to achieve an optical absorption beyond the Yablonovitch limit. This is because the limit is applicable only for geometrical optics of homogeneous materials but not for emerging subwavelength spectral absorbing technologies that include photonic crystal based-cells, wire-based cells, ultra-thin, or inhomogeneously structured cells [388]. For instance, Konedana et al. demonstrated the possibility of attaining an optical absorption beyond the Yablonovitch limit by using subwavelength Si light funnels arrays on silicon-on-insulator (SOI) substrates. And they obtained nearly 5\% absorption enhancement beyond the limit [389]. Wang et al. designed a highly efficient light-trapping structure inspired by natural evolution, and the optimized structure exhibited a 3-fold enhancement beyond the Yablonovitch limit with the broadband absorption efficiency of 48.1\% [390]. An interesting study by Saeta et al. deals with the dipole scatterers embedded in the absorbing layers to enhance the optical absorption in thin metal-backed solar cells. Massive absorption enhancements were observed for strongly coupled dipoles, and a Si:H AR coating of $100 \mathrm{~nm}$ thickness on Ag absorbed about $87 \%$ of incident above-gap light [391].

\section{Effect of Ageing and Environmental Exposure in ARCs and PV Devices}

The implementation of ARCs on the solar cell would suppress the reflection, and in turn, enhances the PCE, but their durability with continuous exposure to the environment and performance degradation characteristics are some novel areas where research is required. Any device or material is subjected to degradation with time. When considering antireflective coatings, the degradation may occur in terms of disintegration between substrate and coating or within different layers, penetration of contaminants, degradation due to weather conditions, and temperature influence. Also, there exists a possibility of adsorption of water or moisture into nanoporous antireflection coatings that can eventually increase the refractive index resulting in a performance degradation [392]. In general, the kinetics of degradation is not fully known concerning PV devices and antireflection coatings, since only little works have been contributed in this domain. The characterization of performance degradation with time and environment can be either observed in a real-time experiment or in a potentially simulated environment to predict the outcome or can be subjected to accelerated ageing tests. Toth et al. performed a durability study on photovoltaic glass coatings as part of a five-year experiment held at five different locations across the world. The prime aspect of their work is to investigate the effects of soiling and cleaning on the coated samples. They observed contaminations including soiling, biological contaminants, and also the impacts of different cleaning methods such as effects of using a dry brush, wet sponge and squeegee, or low-pressure water spray [393]. The impact of damage by soiling depends on the environment and climatic conditions. Still, we need a thorough analysis of the influence of these parameters such as soiling, cleaning, temperature, climatic conditions on power generation of PV cells, or in terms of performance degradation of ARCs. Abraham et al. investigated the durability and the deterioration of the surface and optical properties for fabricated bifunctional hybrid silica sol-gel coatings by performing an aqueous soaking test at various $\mathrm{pH}$ levels [394]. This study also suggests the retrieval of optical properties via heat treatment either entirely or partially. Another study by Zhang et al. fabricated dual-precursor derived antireflective coatings consisting of hollow silica nanospheres. The coating exhibited a 5.08\% increase in average transmission in the $300-1200 \mathrm{~nm}$ wavelength range. The coating is subjected to ultra-long highly-accelerated temperature and humidity stress for $120 \mathrm{~h}$, which is equivalent to a damp heat test at a temperature of $85{ }^{\circ} \mathrm{C}$ with a relative humidity of $85 \%$ for $5000 \mathrm{~h}$ and the deterioration in transmission was found to be below $0.6 \%$ [395]. 
Further, this ARC is deposited on crystalline Si mini-modules, and after performing dust settling and removal tests, the solar cell is observed to have a degradation of $1.15 \%$ in power conversion efficiency. Such test techniques can claim the durability of the coatings in a harsh environment, and many similar testings are encouraged for different AR materials to observe the stability and durability of the coatings. These factors are essential to relate the ageing effects in ARCs and their influence on performance.

On the other hand, the ageing effect on solar cells is also needed to be considered apart from AR coatings, and the effect of UV radiation plays a crucial role in ageing of the PV module. Guiheneuf et al. conducted an accelerated ageing UV exposure test on commercial unencapsulated mono-Si solar cells to determine the ageing effect on the functional properties of solar cells. After a UV exposure of $200 \mathrm{kWh} / \mathrm{m}^{2}$, the unencapsulated solar cells exhibited a significant performance degradation of $-11.23 \%$ in PCE [396]. Further, the reflectance in the 500-900 nm range diminishes due to photo-oxidation of SiNx AR coating. Ageing effect can also be investigated on already installed panels as they would yield a perfect practical observation. One such study was performed by Bouraiou et al. to investigate the various defects that occurred in crystalline Si solar cells under real operating conditions in Algeria. The team analyzed $608 \mathrm{PV}$ modules and categorized the degradation into several modes such as delamination, discoloration of the encapsulant, corrosion, cracks, deterioration of AR coatings, and soiling [397]. Also, the electrical characteristics are tested for some modules to correlate the degradation effect with the performance of the cell. Vicente et al. analyzed the durability of silica film's performance deposited on borosilicate glass and have observed a $1.5 \%$ decrease in the solar transmittance after testing for $1900 \mathrm{~h}$ in a weathering chamber [398].

\section{Discussion}

A brief review of antireflection coatings is covered in this work from various aspects that include structures, fabrication techniques, materials, and the influence on their optical performance and photovoltaic efficiency enhancement. Also, the importance of the light-trapping technique is perceived. In this section, the development of antireflection coating on the basis of structure, material, optical performance, multifunctionality, stability, and cost-effectiveness is discussed to get a big picture of the gravity of this field in photovoltaics.

On the basis of structures, the ARCs range from thin films to nanoporous structures. The thin film ARCs follow the destructive interference principle, whereas porous structures indulge with an index matching approach. Regarding thin-film ARCs, a single layer film suppresses the reflection at target wavelength, and it remains effective only in a narrow range. Double layer thin film ARC is proven to be effective in quite a wide range, and low reflectance can be obtained whereas the multilayer ARC preferably yields a broadband antireflective property. Double layers made of a single material with a different packing density or DLARC made of a different combination of materials is reported with a variety of properties, mainly when different material is used. When incorporating DLARC or multilayer ARCs, material selection and the process for tuning the RI is crucial in modifying the properties of the resulting ARCs. On the other hand, we have ARCs with a nanostructured surface that have gained significant attention in the last decade, including biomimetic structures. These structures have a gradually changing refractive index from air to substrate (GRIN structure), and numerous GRIN structures have been reported, such as nanovoid, nanopillar, nanowire, nanorod, nanotips, and nanopyramid. Here, each structure possesses certain advantages in influencing optical performance. Further, texturization on the surface of substrates or ARCs also proven to be effective in trapping the light, and the well-known pyramidal structure texturization is reported to have remarkable optical characteristics. Some novel studies also outlined different methods for achieving index matching ARCs by stacking layers of nanostructures with a varying hollowness in each layer. Such research is well encouraged as it simplifies the fabrication process.

From the material aspect, AR coatings have been researched and developed in a several class of materials such as Si-based (Silicon, Silica, $\mathrm{SiNx})$, metal-based $(\mathrm{Au}, \mathrm{Ag})$, metal oxide $\left(\mathrm{TiO}_{2}, \mathrm{ZnO}\right.$, ITO), metal fluorides and sulphides $\left(\mathrm{MgF}_{2}, \mathrm{ZnS}\right)$, polymer-based (Polystyrene, PMMA, PET, PDMS), 
and advanced materials including carbon nanotubes and graphite. Apart from these, composite materials constituting double layer, multiple layer ARCs have been developed. It is seen that silica, titanium dioxide, and Zinc oxide are the widely researched materials for antireflection coatings, as many studies related to it have been found. Further, each material has some inherent qualities that might lead to multifunctional AR coatings. For example, $\mathrm{TiO}_{2}$ enhances the photocatalytic activity, SiNx improves passivation property, Silica is naturally mechanically robust when tightly packed, most $\mathrm{MgF}_{2}$ coatings support hydrophobic characteristics, and so on. The fabrication technique is the key for controlling the structural parameters that influence the material to exhibit its inherent properties to give a maximum desired benefit.

On the basis of optical properties, three parameters are of utmost importance, which are refractive index, transmittance or reflectance, and the wavelength range, upon which the whole review information is gathered. These parameters would describe the prime performance of an ARC and its light trapping ability. A transmittance of more than $90 \%$ and reflectance less than $10 \%$ is achieved in most of our reviewed work. But a perfect ARC would exhibit its antireflective property in broadband wavelength range covering the visible region entirely and partially in UV or IR portions of the spectrum and possesses omnidirectional antireflectivity. When considering the work reviewed, about $40 \%$ of them possess broadband antireflection characteristics, and only a few possess omnidirectional antireflectivity. On further analysis, it is inferred that metal-based antireflection coatings demonstrate a greater number of reported broadband antireflectivity while some silicon-based materials also impart this property. The optical properties are influenced by the structural arrangement, density of the medium, period between structures in case of textured coatings, and all these factors indirectly depend on the flexibility of fabrication methodology used.

Multifunctional antireflective coatings are of great interest and are much-needed. Currently available multifunctional coatings include self-cleaning coatings (hydrophobic coatings), photoactive superhydrophilic coatings, transparent conductive coatings, and antimicrobial coatings. The multifunctional behavior is mainly attributed to the material inherent properties, and secondly, structural characteristics also have an impact to some extent. In our study, among multifunctional coatings, the hydrophobic characteristic are commonly reported. A detailed review of multifunctional coatings is provided in the referred study [35].

Though an AR coating possesses good optical properties, its degradation of performance with ageing is an important parameter to be considered. Such performance degradation analysis is carried out only in a few studies. A separate section of ageing effects on ARC and PV is discussed in our study, where the commonly used methods for predicting the performance degradation intensity and its impact on the performance of PV is provided. The stability of coatings with the substrate and with various environmental conditions, durability are all some essential characteristics that can be determined from the coatings resistive nature to temperature, moisture, UV exposure, and chemicals. Certain sophisticated experiments need to be performed to predict these parameters, and this will create a positive impact on the further development of antireflection coatings. Regarding the cost analysis, coating material and fabrication methodology shares the role. There is no point in manufacturing an ARC that has suitable properties and being expensive. While AR coatings have already been fabricated in low-cost methodologies, as reported in many studies, preparing the high-performance coating in a cost-effective approach can gain immense attention in the field of photovoltaics. 
The prime objective of this work is to review the various strategies proposed and researched to enhance the photon's availability for photovoltaic conversion. Moreover, it is necessary to provide a comparison for the reviewed ARCs to understand the current status of research and development. Since vast information is collected and processed, we decided to present a table that will provide a comparison between various antireflection coatings in reference to perfect AR coatings characteristics. Out of all reviewed AR coatings, only high-performance ARC from each table is selected and presented in Table 9. The AR coatings that have either a transmittance higher than $95 \%$ or reflectance lesser than $5 \%$ are first chosen and are further sorted with an additional parameter of its effective wavelength range difference having more than $600 \mathrm{~nm}$ (preferably more than the visible range). From the table, we can infer that the many ARCs made of silica nanoparticles exhibit excellent optical performance in a broad wavelength range. A particular study [115] reports to have a broadband transmittance of about $99.04 \%$ (in 380-1600 nm) which is astonishing. In addition, several other studies indicates more than $97 \%$ transmittance. Besides, stability and durability tests of particular silica coating [106] show its mechanical robustness and longevity for such coatings. Even cheap and straightforward fabrication methods for obtaining silica ARCs are reported in many research works. Hence, high-performance silica nanoparticles fabricated in a cost-effective approach proving the stability and durability of the coatings have immense potential to act as a valid AR coating in commercially available PV devices. Apart from silica, $\mathrm{TiO}_{2}$ material is another potential candidate which can impart photocatalytic properties to the AR coatings. Such coatings are highly suitable for thin-film solar cells, multijunction solar cells, dye-sensitized solar cells, and emerging transparent photovoltaics. Polymer coatings, though possessing excellent optical performance, it needs more research in terms of achieving broadband antireflectivity with simple fabrication techniques, stability, and durability. We authors suggest the researchers to consider the performance degradation due to ageing of ARCs, which is the lagging information in most research that would benefit a lot in determining the suitable ARC application. 
Table 9. Comparison of various high-performance coatings with respect to perfect AR coating characteristics.

\begin{tabular}{|c|c|c|c|c|c|c|c|c|c|c|}
\hline \multirow[b]{2}{*}{$\begin{array}{l}\text { AR Coating } \\
\text { Material }\end{array}$} & \multirow[b]{2}{*}{ AR Structure } & \multirow{2}{*}{$\begin{array}{l}\text { Fabrication } \\
\text { Technology }\end{array}$} & \multicolumn{3}{|c|}{ Optical Performance } & \multirow{2}{*}{$\begin{array}{c}\text { Broadband } \\
\text { Antireflectivity }\end{array}$} & \multirow[b]{2}{*}{ Multifunctionality } & \multirow{2}{*}{$\begin{array}{l}\text { Stability and } \\
\text { Durability }\end{array}$} & \multirow[b]{2}{*}{$\begin{array}{l}\text { Feasibility and } \\
\text { Cost-Effectiveness }\end{array}$} & \multirow[b]{2}{*}{ Source } \\
\hline & & & $\begin{array}{l}\text { Reflectance } \\
(\%)\end{array}$ & $\begin{array}{c}\text { Transmittance } \\
(\%)\end{array}$ & $\begin{array}{l}\text { Wavelength } \\
\text { Range (nm) }\end{array}$ & & & & & \\
\hline Silica & $\begin{array}{l}\text { Closed-surface silica AR thin } \\
\text { film }\end{array}$ & $\begin{array}{l}\text { Acid catalyst sol-gel } \\
\text { method }\end{array}$ & - & 97.1 & $300-1200$ & Yes & No & $\begin{array}{l}\text { Highly stable and } \\
\text { durable. } 5 \mathrm{H} \\
\text { pencil hardness, } \\
\text { damp test showed } \\
\text { excellent moisture } \\
\text { and temperature } \\
\text { resistance }\end{array}$ & $\begin{array}{l}\text { Dip-coating method } \\
\text { is used. Simple, } \\
\text { convenient and } \\
\text { cost-effective } \\
\text { method }\end{array}$ & [106] \\
\hline Silica & Four layer Nanoporous $\mathrm{SiO}_{2}$ & $\begin{array}{l}\text { Glancing angle } \\
\text { deposition } \\
\text { technique }\end{array}$ & 0.04 & - & $400-800$ & No & No & No information & $\begin{array}{l}\text { Involves complex } \\
\text { fabrication of thin } \\
\text { film layers }\end{array}$ & [114] \\
\hline Silica & $\begin{array}{l}\text { Five layer hollow silica } \\
\text { nanoparticles }\end{array}$ & Dip-coating method & - & 99.04 & $380-1600$ & $\begin{array}{l}\text { Omnidirectional } \\
\text { broadband } \\
\text { antireflectivity }\end{array}$ & No & No information & $\begin{array}{l}\text { Simple method, } \\
\text { feasible for large } \\
\text { area manufacturing }\end{array}$ & [115] \\
\hline $\begin{array}{c}\text { Porous } \\
\text { silicon (PS) }\end{array}$ & $\begin{array}{l}\text { (i) Single layer PS } \\
\text { (ii) doube layer PS }\end{array}$ & $\begin{array}{l}\text { Electrochemical } \\
\text { process }\end{array}$ & $\begin{array}{c}\text { Single } \\
\text { layer- 7 } \\
\text { Double } \\
\text { layer- 3 }\end{array}$ & - & $400-1000$ & No & No & No information & $\begin{array}{l}\text { Multiple PSi layers } \\
\text { can be formed in } \\
\text { one step process }\end{array}$ & [102] \\
\hline $\begin{array}{l}\text { Silicon } \\
\text { nitride }\end{array}$ & $\begin{array}{l}\text { Single layer SiNx on textured } \mathrm{Si} \\
\text { wafer }\end{array}$ & Plasma deposition & $<2.5$ & $>97$ & $300-1000$ & Yes & No & No information & $\begin{array}{l}\text { Industrially used } \\
\text { method of PECVD } \\
\text { is used. } \\
\text { Implementation } \\
\text { will be easier }\end{array}$ & [122] \\
\hline $\mathrm{TiO}_{2}$ & $\begin{array}{l}\mathrm{TiO}_{2} \text { thin films deposited on } \\
\text { textured } \mathrm{Si} \text { substrate }\end{array}$ & $\begin{array}{l}\text { High impulse } \\
\text { power magnetron } \\
\text { sputtering }\end{array}$ & $<3$ & - & $400-1100$ & Yes & No & No information & $\begin{array}{l}\text { Large scale } \\
\text { manufacturing isn't } \\
\text { cost-effective with } \\
\text { HiPIMS }\end{array}$ & [153] \\
\hline $\mathrm{TiO}_{2}$ & Double layer $\mathrm{TiO}_{2}$ film & $\begin{array}{l}\text { Atmospheric } \\
\text { pressure chemical } \\
\text { vapor deposition }\end{array}$ & 6.5 & - & $350-1150$ & Yes & No & No information & $\begin{array}{l}\text { Low cost, US } \$ 0.05 \\
\text { per } 100 \mathrm{~mm} \times 100 \\
\text { mm wafer }\end{array}$ & [154] \\
\hline $\mathrm{MgF}_{2}$ & $\begin{array}{l}\text { Mesoporous } \mathrm{MgF}_{2} \\
\text { nanoparticles }\end{array}$ & $\begin{array}{l}\text { Lyothermal } \\
\text { synthesis and Dip } \\
\text { coating process }\end{array}$ & - & 97.03 & $300-1500$ & Yes & Hydrophobic film & $\begin{array}{l}\text { Environmentally } \\
\text { and mechanically } \\
\text { stable coating }\end{array}$ & $\begin{array}{l}\text { Simple technique } \\
\text { and cost-effective } \\
\text { methodology }\end{array}$ & [187] \\
\hline $\mathrm{ZnO}$ & Moth eye structure & $\begin{array}{l}\text { Aqueous solution } \\
\text { method }\end{array}$ & 1.46 & - & $200-800$ & No & No & No information & - & [188] \\
\hline
\end{tabular}


Table 9. Cont

\begin{tabular}{|c|c|c|c|c|c|c|c|c|c|c|}
\hline \multirow{2}{*}{$\begin{array}{l}\text { AR Coating } \\
\text { Material }\end{array}$} & \multirow[b]{2}{*}{ AR Structure } & \multirow{2}{*}{$\begin{array}{l}\text { Fabrication } \\
\text { Technology }\end{array}$} & \multicolumn{3}{|c|}{ Optical Performance } & \multirow{2}{*}{$\begin{array}{c}\text { Broadband } \\
\text { Antireflectivity }\end{array}$} & \multirow[b]{2}{*}{ Multifunctionality } & \multirow{2}{*}{$\begin{array}{l}\text { Stability and } \\
\text { Durability }\end{array}$} & \multirow{2}{*}{$\begin{array}{l}\text { Feasibility and } \\
\text { Cost-Effectiveness }\end{array}$} & \multirow[b]{2}{*}{ Source } \\
\hline & & & $\begin{array}{l}\text { Reflectance } \\
(\%)\end{array}$ & $\begin{array}{c}\text { Transmittance } \\
(\%)\end{array}$ & $\begin{array}{l}\text { Wavelength } \\
\text { Range (nm) }\end{array}$ & & & & & \\
\hline Polystyrene & Biomimetic nanopillars & $\begin{array}{l}\text { Microinjection } \\
\text { compression } \\
\text { molding }\end{array}$ & $\sim 4$ & - & 400-1000 & No & $\begin{array}{l}\text { Hydrophobic } \\
\text { coating }\end{array}$ & No information & $\begin{array}{l}\text { Rapid fabrication } \\
\text { and efficient } \\
\text { replication method }\end{array}$ & [197] \\
\hline PMMA & Nanopatterns & $\begin{array}{l}\text { Thermal } \\
\text { nanoimprinting, } \\
\text { laser lithography } \\
\text { and dry etching }\end{array}$ & $<0.5$ & - & $400-800$ & No & $\begin{array}{l}\text { Antiwettability, } \\
\text { antiadhesion and } \\
\text { antimicrobial } \\
\text { coating }\end{array}$ & No information & $\begin{array}{l}\text { Complicated } \\
\text { fabrication } \\
\text { technique }\end{array}$ & [5] \\
\hline PET & Nano-cone array & $\begin{array}{l}\text { Reactive-ion } \\
\text { Etching }\end{array}$ & $<0.5$ & $>97$ & $300-900$ & No & $\begin{array}{l}\text { Superhydrophobic } \\
\text { coating }\end{array}$ & No information & $\begin{array}{l}\text { Facile method but } \\
\text { requires } \\
\text { sophisticated } \\
\text { equipment }\end{array}$ & [190] \\
\hline $\begin{array}{l}\mathrm{SiO}_{2} \text { and } \\
\mathrm{TiO}_{2}\end{array}$ & $\begin{array}{ll}\text { (i) } & \mathrm{TiO}_{2} \text { single layer } \\
\text { (ii) } & \mathrm{SiO}_{2} / \mathrm{TiO}_{2} \text { double-layer } \\
\text { (iii) } & \mathrm{SiO}_{2} / \mathrm{SiO}_{2}-\mathrm{TiO}_{2} / \mathrm{TiO}_{2} \\
& \text { triple-layer }\end{array}$ & Sol-gel method & $\begin{array}{ll}\text { (i) } & 9.3 \\
\text { (ii) } & 6.2 \\
\text { (iii) } & 3.2\end{array}$ & - & $400-1000$ & No & No & No information & $\begin{array}{l}\text { Low-cost } \\
\text { fabrication } \\
\text { approach }\end{array}$ & [216] \\
\hline $\begin{array}{l}\mathrm{SiO}_{2} \text { and } \\
\mathrm{TiO}_{2}\end{array}$ & Double-layer $\mathrm{SiO}_{2} / \mathrm{TiO}_{2}$ coating & $\begin{array}{l}\text { Surface sol-gel } \\
\text { process }\end{array}$ & - & 97.7 & $400-1200$ & Yes & $\begin{array}{l}\text { Photocatalytic and } \\
\text { hydrophobic } \\
\text { coating }\end{array}$ & $\begin{array}{l}\text { Mechanically } \\
\text { robust, moisture } \\
\text { resistance, } \\
\text { long-term stability } \\
\text { against } \\
\text { temperature and } \\
\text { durable }\end{array}$ & $\begin{array}{l}\text { Simple and facile } \\
\text { fabrication method }\end{array}$ & [223] \\
\hline $\begin{array}{c}\mathrm{ZnO} \text { and } \\
\mathrm{SiO}_{2}\end{array}$ & $\begin{array}{l}\text { Nanoporous } \mathrm{ZnO} / \mathrm{SiO}_{2} \text { bilayer } \\
\text { coating }\end{array}$ & $\begin{array}{l}\text { Sol-gel dip-coating } \\
\text { method }\end{array}$ & 2.4 & 96.1 & $300-1200$ & Yes & No & No information & $\begin{array}{l}\text { Cost-effective } \\
\text { fabrication } \\
\text { technique }\end{array}$ & [235] \\
\hline $\begin{array}{l}\mathrm{MgF}_{2} \text { and } \\
\mathrm{ZnO}\end{array}$ & $\begin{array}{l}\text { Double layer } \mathrm{MgF}_{2} \text { and } \mathrm{Zno} \\
\text { nanorods layer }\end{array}$ & RF sputtering & 5.5 & - & $300-1000$ & Yes & No & No information & Expensive method & [237] \\
\hline
\end{tabular}




\section{Challenges, Prospects, and Conclusions}

Antireflection coatings are indispensable in the PV applications, and their performance is consistently improvising over the course of time, thanks to all the researcher's continuous efforts. The prime function of ARC is to reduce the reflectance over a broad spectrum with Omni-directional anti-reflectivity by using different materials, structures, and topography. Though many types of researches have contributed to achieving these results, an ARC with all prime functions is rare, and further, it raises the question of stability, reliability with PV over the course of time. Currently, ARCs demonstrating very low reflectance or high transmittance are not effective for a broadband range and even, if it is effective in some instances, it is limited to its narrow range of incident angle. Thus, researches focusing on tuning the defining characters of ARCs to achieve an optimized coating that remains effective in all conditions is much needed. Moreover, the working environment is different, which demands additional research. Modeling, simulation, and analysis are promising approaches in determining the basic optical parameters, such as refractive index and reflectivity for a different combination of materials, and the subsequent experimental verification would be useful in real-world applications.

The performance of the PV cells diminishes with the accumulation of dust, moisture, and microbes. That is where the emergence of ARCs having multiple functions developed in recent years. Thus, the interest in developing hybrid coatings is widening, which serves as an antireflection coating, self-cleaning coatings and as an encapsulant in commercially viable crystalline Si solar modules that would account for a substantial improvement in PV sector. Certain studies have also reported a self-cleaning ARC exhibiting excellent stability, resistant to harsh environmental conditions, with good mechanical properties along with high transmission at broadband wavelengths. However, there still exists a considerable gap between durability and affordability. Kim et al. developed a nanoimprinted polymer films showing a multifunctional behavior such as antimicrobial, antireflective, and antiadhesion properties [5]. This opens up a pioneering application in medical fields, and many such types of researches are required to prove its viability. Researches focusing on the longevity of the coating's performance is much appreciated.

A novel study by Druffel et al. [399] on ceramic thin-films and polymer nanocomposites reported that the ceramic thin-films are prone to brittle fracture. On the other hand, the material having the ductile nature of failure tend to possess durability, but to go in hand with the whole lifespan of the PV cell with consistent performance is still a question to answer. Usually, owing to the difference in thermal coefficients of different materials, the residual stress might build up between the substrate and the coating. For instance, if the coating material has low thermal expansion than that of substrate material, the substrate expands more than the coating and due to which the substrate experiences a higher contraction while the coating is under tension. This results in the bending of the overall configuration. On the contrary, if the coating material has higher thermal expansion than that of substrate material, the coating experiences a higher contraction, whereas the substrate is under tension, which also results in bending but in the opposite direction. Recent trends in ARC also focuses on low-emissivity characteristics of the coatings. This analysis could contribute to a certain extent to decrease the heat transferred to the solar cells from the surroundings is and also useful in applications such as windows for radiation thermometry, sensing, and so on.

From material aspects, after the emergence of a wonder material, graphene, world-wide researchers have contributed much effort in exploring an effective production methodology and its application. It is also best suited for the PV sector in numerous ways, such a transparent electrode, antireflection coating, and many others. The graphene layer possesses highly efficient optical absorption properties over a broad wavelength ranging from mid-infrared (IR) to ultraviolet (UV) spectrum [251], achieving super broadband antireflection with a light absorption efficiency as high as $99 \%$. The prominent antireflective coating materials such as $\mathrm{SiO}_{2}, \mathrm{TiO}_{2}, \mathrm{SiNx}: \mathrm{H}, \mathrm{ZnO}, \mathrm{MgF}_{2}$, and their composites have well studied, and their implication on suitable PV applications is yet to explore. Polymers, on the other hand, prove to be a better ARC, but other perspectives dealing with low-cost fabrication methods, stability on PV 
analysis, and efficiency enhancement remain to be investigated. Also, polymer material like Norland optical adhesive 63 (NOA63) and some more UV-curable polymers are widely employed as ARCs to improve the light propagation in many optical devices that have the potential to be extended to the PV field [400-402].

The ARC also plays a crucial role in the new generation of organic solar cell technology. A study reveals that an organic solar cell having a structure of glass/ITO/PEDOT is reported to exhibit reduced reflection with an additional coating of moth's eye based nanostructured arrays, and also, the coating enhances the PCE of the solar cell by 2.5-3\% [403]. Emerging PV technologies such as transparent solar cells, flexible solar cells, and dye-sensitized solar cells also require AR coatings of desirable properties. For instance, for flexible solar cells, the AR coating should have flexible properties apart from its fundamental optical properties to suit the application. Further, many novel photovoltaic technologies have been researched and developed, such as bifacial solar photovoltaics [404], where the role of AR coating is of utmost importance.

The desired properties of the AR coating is obtained from the nature of the material and the structure of the coating. The development of bioinspired and biomimetic ARCs would help us to fabricate increasingly more advanced biomimetic functional materials that have the potential for widespread applications. The moth-eye structure has gained attention among scholars, and many pioneering structures are produced and researched. Further, porous structures and textured surfaces still have a space to improve in terms of fabrication in large-scale, cost-effective techniques. The feasibility of an antireflection coating relies on its unique properties and manufacturing methods. Designing the fabrication technique in which the operating parameters can be precisely controlled is a significant factor that impacts the topography of ARCs, and the research in optimizing the fabricating process is also encouraged.

An essential aspect of ARC is its influence on efficiency enhancement. Though the reflectivity is reduced, it is desirable to know its effect on efficiency enhancement in various types of PV cells. This data can help us to identify the most suitable AR coating for a different class of PV devices in a more effective way. The implementation of light trapping techniques in the PV device will significantly enhance its performance. The applications of plasmonics in the PV sector are very prospective, and it does have the potential for downsizing the solar cell and ultimately reducing the cost. The spectral modification techniques, such as down-conversion and up-conversion methods are emerging. Although the down-conversion technique has reported having an impact on the PCE of the solar cell, the up-conversion techniques lag behind, which should be backed up with innovations. Further, some innovative light-trapping structures have proved their potential in maximizing the absorption approaching or even conquering the Yablonovitch limit. Imagine the effect of combining all these light trapping techniques in a single device, and that would be astonishing. Indeed, there are some reports that utilized these techniques along with antireflective coatings. Further, the development and refining of these techniques in the field of PV is a desideratum.

In general, antireflective coatings are used in a wide range of optical and optoelectronic applications, including eyeglasses, mirrors, lenses, laser applications, automobile anti-glare glasses, diodes, cameras, photovoltaics, window glasses, and almost in every day to day applications. Also, in-depth research analysis in antireflection coatings is carried out in areas such as electrochromism $[405,406]$ and thermochromism [407] apart from photovoltaic fields. Therefore, new developments create enormous opportunities for customizing ARCs to suit particular applications with cutting edge technology and product improvisation.

To conclude, nature and science have guided us to achieve what we know now. The anti-reflective coating (ARC) is an essential technology with innovations rolling over it, opening up a broad field of applications. As of now, the primary functions of antireflection (AR) coatings have been fully utilized, and further additional functions of the coating are being imparted and researched. The growing technology and state-of-art fabrication techniques would support us in researching more about AR structures and surfaces and their impact on photovoltaics (PVs). Natural structures are unique, 
and their replication has shown promising results, yet the production of such structures isn't easier or cost-effective. Moreover, various materials are found to be suitable for antireflection coatings, and advanced materials are still emerging. So, further analysis of such ARCs from a PV perspective is needed. This review provides some valuable insight into the current trends of ARC and its evolution from the past. Furthermore, research addressing the current challenges in ARC applications (as presented above) should be guided towards commercialization.

Author Contributions: Conceptualization, R.P., R.M.E. and N.S.; Data curation, R.P.; Formal analysis, R.P., R.M.E. and N.S.; Methodology, R.P. and R.M.E.; Visualization, R.P.; Comprehensive analysis, R.P. and R.M.E.; Writing-Original draft preparation, R.P., R.M.E. and N.S.; Supervision, R.M.E.; Review validation, R.M.E.; Editing, R.P. and R.M.E.; Reviewing, R.M.E., N.S., N.D. and P.K.; Funding acquisition (towards APC), R.M.E and N.D. All authors have read and agreed to the published version of the manuscript.

Funding: This research activity received no external funding.

Conflicts of Interest: The authors declare no conflict of interest.

\section{Nomenclature}

\begin{tabular}{|c|c|c|c|}
\hline ARC & Antireflection coatings & $\mathrm{SiO}_{2}$ & Silica or Silicon dioxide \\
\hline PV & Photovoltaics & SiNWs & Silicon Nanowires \\
\hline PCE & Power conversion efficiency & PSi & Porous Silicon \\
\hline GRIN & Gradient refractive index & $\mathrm{TiO}_{2}$ & Titanium Oxide \\
\hline SWS & Subwavelength structure & $\mathrm{ZnO}$ & Zinc oxide \\
\hline RI & Refractive index & $\mathrm{MgF}_{2}$ & Magnesium fluoride \\
\hline$n_{\mathrm{s}}$ & Index of refraction of the substrate & ITO & Indium Tin oxide \\
\hline$\lambda$ & Wavelength of the light & FTO & Fluorine doped tin oxide \\
\hline AGC & Antiglare coatings & $\mathrm{Ta}_{2} \mathrm{O}_{5}$ & Tantalum Pentoxide \\
\hline SLARC & Single layer antireflection coating & PS & Polystyrene \\
\hline DLARC & Double layer antireflection coating & PMMA & Poly (methyl methacrylate) \\
\hline QLARC & Quadruple-layer ARC & PDMS & Polydimethylsiloxane \\
\hline CBD & Chemical bath deposition & PET & Polyethylene terephthalate \\
\hline CVD & Chemical vapor deposition & CNT & Carbon nano-tubes \\
\hline PECVD & Plasma-enhanced chemical vapor deposition & SWCNT & Single-walled carbon nanotube \\
\hline RF-PECVD & $\begin{array}{l}\text { Radio frequency Plasma-enhanced chemical } \\
\text { vapor deposition }\end{array}$ & MWCNT & Multi-walled carbon nanotube \\
\hline APCVD & $\begin{array}{l}\text { Atmospheric pressure chemical vapor } \\
\text { deposition }\end{array}$ & $\mathrm{c}-\mathrm{Si}$ & Crystalline Silicon \\
\hline NIL & Nanoimprint Lithography & $\mathrm{CPV}$ & Concentrated Photovoltaics \\
\hline FIBL & Focused ion-beam Lithography & DSSC & dye-sensitized solar cells \\
\hline RIE & Reactive ion etching & GaAs & Gallium Arsenide \\
\hline LPD & Liquid phase deposition & CIGS & Copper indium gallium selenide \\
\hline WCA & Water contact angle & PSC & Perovskite solar cells \\
\hline
\end{tabular}

\section{References}

1. Dong, C.; Lu, H.; Yu, K.; Shen, K.-S.; Zhang, J.; Xia, S.-Q.; Xiong, Z.-G.; Liu, X.-Y.; Zhang, B.; Wang, Z.-J.; et al. Low emissivity double sides antireflection coatings for silicon wafer at infrared region. J. Alloy Compd. 2018, 742, 729-735. [CrossRef]

2. Leon, J.J.D.; Hiszpanski, A.M.; Bond, T.C.; Kuntz, J.D. Design Rules for Tailoring Antireflection Properties of Hierarchical Optical Structures. Adv. Opt. Mater. 2017, 5, 1700080. [CrossRef]

3. Leem, J.W.; Yu, J.S. Artificial inverted compound eye structured polymer films with light-harvesting and self-cleaning functions for encapsulated III-V solar cell applications. RSC Adv. 2015, 5, 60804-60813. [CrossRef]

4. Raut, H.K.; Dinachali, S.S.; He, A.Y.; Ganesh, V.A.; Saifullah, M.S.M.; Law, J.; Ramakrishna, S. Robust and durable polyhedral oligomeric silsesquioxane-based anti-reflective nanostructures with broadband quasi-omnidirectional properties. Energy Environ. Sci. 2013, 6, 1929. [CrossRef] 
5. Kim, S.; Jung, U.T.; Kim, S.-K.; Lee, J.-H.; Choi, H.S.; Kim, C.-S.; Jeong, M.Y. Nanostructured Multifunctional Surface with Antireflective and Antimicrobial Characteristics. ACS Appl. Mater. Interfaces 2015, 7, 326-331. [CrossRef]

6. Peng, Y.-J.; Huang, H.-X.; Xie, H. Rapid fabrication of antireflective pyramid structure on polystyrene film used as protective layer of solar cell. Sol. Energy Mater. Sol. Cells 2017, 171, 98-105. [CrossRef]

7. Zhang, X.; Ji, D.; Lei, T.; Zhao, B.; Song, K.; Hu, W.; Wang, J.-Y.; Pei, J.; Wang, Y. Integration of antireflection and light diffraction in nature: A strategy for light trapping. J. Mater. Chem. A 2013, 1, 10607. [CrossRef]

8. Kuo, S.-Y.; Hsieh, M.-Y.; Han, H.-V.; Lai, F.-I.; Chuang, T.-Y.; Yu, P.; Lin, C.-C.; Kuo, H.-C. Flexible-textured polydimethylsiloxane antireflection structure for enhancing omnidirectional photovoltaic performance of $\mathrm{Cu}(\mathrm{In}, \mathrm{Ga}) \mathrm{Se} 2$ solar cells. Opt. Express 2014, 22, 2860. [CrossRef]

9. Bernhard, C.G.; Miller, W.H. A Corneal Nipple Pattern in Insect Compound Eyes. Acta Physiol. Scand. 1962, 56, 385-386. [CrossRef]

10. Stavenga, D.G.; Foletti, S.; Palasantzas, G.; Arikawa, K. Light on the moth-eye corneal nipple array of butterflies. Proc. R. Soc. B Biol. Sci. 2006, 273, 661-667. [CrossRef]

11. Siddique, R.H.; Gomard, G.; Holscher, H. The role of random nanostructures for the omnidirectional anti-reflection properties of the glasswing butterfly. Nat. Commun. 2015, 6, 6909. [CrossRef] [PubMed]

12. Yoshida, A.; Motoyama, M.; Kosaku, A.; Miyamoto, K. Antireflective Nanoprotuberance Array in the Transparent Wing of a Hawkmoth, Cephonodes hylas. Zool. Sci. 1997, 14, 737-741. [CrossRef]

13. Morikawa, J.; Ryu, M.; Seniutinas, G.; Balcytis, A.; Maximova, K.; Wang, X.; Zamengo, M.; Ivanova, E.P.; Juodkazis, S. Nanostructured Antireflective and Thermoisolative Cicada Wings. Langmuir 2016, 32, 4698-4703. [CrossRef] [PubMed]

14. Bagge, L.E.; Osborn, K.J.; Johnsen, S. Nanostructures and Monolayers of Spheres Reduce Surface Reflections in Hyperiid Amphipods. Curr. Biol. 2016, 26, 3071-3076. [CrossRef]

15. Cronin, T.W. Camouflage: Being Invisible in the Open Ocean. Curr. Biol. 2016, 26, R1179-R1181. [CrossRef]

16. Wu, L.; He, J.; Shang, W.; Deng, T.; Gu, J.; Su, H.; Liu, Q.; Zhang, W.; Zhang, D. Optical Functional Materials Inspired by Biology. Adv. Opt. Mater. 2015, 4, 195-224. [CrossRef]

17. Gu, J.; Zhang, W.; Su, H.; Fan, T.; Zhu, S.; Liu, Q.; Zhang, D. Morphology Genetic Materials Templated from Natural Species. Adv. Mater. 2014, 27, 464-478. [CrossRef]

18. Leem, J.W.; Kim, S.; Lee, S.H.; Rogers, J.A.; Kim, E.; Yu, J.S. Efficiency Enhancement of Organic Solar Cells Using Hydrophobic Antireflective Inverted Moth-Eye Nanopatterned PDMS Films. Adv. Energy Mater. 2014, 4, 1301315. [CrossRef]

19. Woo Leem, J.; Guan, X.-Y.; Choi, M.; Su Yu, J. Broadband and omnidirectional highly-transparent coverglasses coated with biomimetic moth-eye nanopatterned polymer films for solar photovoltaic system applications. Sol. Energy Mater. Sol. Cells 2015, 134, 45-53. [CrossRef]

20. Ghymn, Y.H.; Jung, K.; Shin, M.; Ko, H. A luminescent down-shifting and moth-eyed anti-reflective film for highly efficient photovoltaic devices. Nanoscale 2015, 7, 18642-18650. [CrossRef]

21. Oh, Y.-J.; Kim, J.-J.; Jeong, K.-H. Biologically Inspired Biophotonic Surfaces with Self-Antireflection. Small 2014, 10, 2558-2563. [CrossRef]

22. Ji, S.; Park, J.; Lim, H. Improved antireflection properties of moth eye mimicking nanopillars on transparent glass: Flat antireflection and color tuning. Nanoscale 2012, 4, 4603. [CrossRef]

23. Lin, C.-Y.; Lin, K.-Y.A.; Yang, T.-W.; Chen, Y.-C.; Yang, H. Self-assembled hemispherical nanowell arrays for superhydrophobic antireflection coatings. J. Colloid Interface Sci. 2017, 490, 174-180. [CrossRef]

24. Park, J.Y.; Lee, I.; Ham, J.; Gim, S.; Lee, J.-L. Simple and scalable growth of AgCl nanorods by plasma-assisted strain relaxation on flexible polymer substrates. Nat. Commun. 2017, 8, 15650. [CrossRef]

25. Lai, F.-I.; Yang, J.-F.; Liao, W.-X.; Kuo, S.-Y. Enhanced omnidirectional and weatherability of $\mathrm{Cu}_{2} \mathrm{ZnSnSe}_{4}$ solar cells with $\mathrm{ZnO}$ functional nanorod arrays. Sci. Rep. 2017, 7, 14927. [CrossRef]

26. Buencuerpo, J.; Llorens, J.M.; Dotor, M.L.; Ripalda, J.M. Broadband antireflective nano-cones for tandem solar cells. Opt. Express 2015, 23, A322. [CrossRef]

27. Zhang, C.; Li, W.; Yu, D.; Wang, Y.; Yin, M.; Wang, H.; Song, Y.; Zhu, X.; Chang, P.; Chen, X.; et al. Wafer-Scale Highly Ordered Anodic Aluminum Oxide by Soft Nanoimprinting Lithography for Optoelectronics Light Management. Adv. Mater. Interfaces 2017, 4, 1601116. [CrossRef]

28. Benito, N.; Recio-Sanchez, G.; Escobar-Galindo, R.; Palacio, C. Formation of antireflection Zn/ZnO core-shell nano-pyramidal arrays by $\mathrm{O} 2+$ ion bombardment of $\mathrm{Zn}$ surfaces. Nanoscale 2017, 9, 14201-14207. [CrossRef] 
29. Huang, Y.-F.; Chattopadhyay, S.; Jen, Y.-J.; Peng, C.-Y.; Liu, T.-A.; Hsu, Y.-K.; Pan, C.-L.; Lo, H.-C.; Hsu, C.-H.; Chang, Y.-H.; et al. Improved broadband and quasi-omnidirectional anti-reflection properties with biomimetic silicon nanostructures. Nat. Nanotechnol. 2007, 2, 770-774. [CrossRef]

30. IPA Adriatic Cross-Border Cooperation. Photovoltaic Systems; REA Kvarner Ltd.: Rijeka, Croatia, 2012.

31. International Technology Roadmap for Photovoltaic (ITRPV), ITRPV 2019 Reports. Available online: https://itrpv.vdma.org/ (accessed on 17 March 2020).

32. Klimm, E.; Lorenz, T.; Weiss, K. Can anti-soiling coating on solar glass influence the degree of performance loss over time of PV modules drastically? In Proceedings of the 28th European PV Solar Energy Conference, Paris, France, 30 September-4 October 2013.

33. Midtdal, K.; Jelle, B.P. Self-cleaning glazing products: A state-of-the-art review and future research pathways. Sol. Energy Mater. Sol. Cells 2013, 109, 126-141. [CrossRef]

34. Sarkın, A.S.; Ekren, N.; Saglam, S. A review of anti-reflection and self-cleaning coatings on photovoltaic panels. Sol. Energy 2020, 199, 63-73. [CrossRef]

35. Mozumder, M.S.; Mourad, A.-H.I.; Pervez, H.; Surkatti, R. Recent developments in multifunctional coatings for solar panel applications: A review. Sol. Energy Mater. Sol. Cells 2019, 189, 75-102. [CrossRef]

36. Han, Z.; Jiao, Z.; Niu, S.; Ren, L. Ascendant Bioinspired Antireflective Materials: Opportunities and Challenges Coexist. Prog. Mater. Sci. 2019, 103, 1-68. [CrossRef]

37. Hanaei, H.; Assadi, M.K.; Saidur, R. Highly efficient antireflective and self-cleaning coatings that incorporate carbon nanotubes (CNTs) into solar cells: A review. Renew. Sustain. Energy Rev. 2016, 59, 620-635. [CrossRef]

38. Han, Z.W.; Wang, Z.; Feng, X.M.; Li, B.; Mu, Z.Z.; Zhang, J.Q.; Niu, S.C.; Ren, L.Q. Antireflective surface inspired from biology: A review. Biosurface Biotribol. 2016, 2, 137-150. [CrossRef]

39. Mehmood, U.; Al-Sulaiman, F.A.; Yilbas, B.S.; Salhi, B.; Ahmed, S.H.A.; Hossain, M.K. Superhydrophobic surfaces with antireflection properties for solar applications: A critical review. Sol. Energy Mater. Sol. Cells 2016, 157, 604-623. [CrossRef]

40. Yao, L.; He, J. Recent progress in antireflection and self-cleaning technology-From surface engineering to functional surfaces. Prog. Mater. Sci. 2014, 61, 94-143. [CrossRef]

41. Raut, H.K.; Ganesh, V.A.; Nair, A.S.; Ramakrishna, S. Anti-reflective coatings: A critical, in-depth review. Energy Environ. Sci. 2011, 4, 3779. [CrossRef]

42. Chattopadhyay, S.; Huang, Y.F.; Jen, Y.J.; Ganguly, A.; Chen, K.H.; Chen, L.C. Anti-reflecting and photonic nanostructures. Mater. Sci. Eng. R Rep. 2010, 69, 1-35. [CrossRef]

43. Rayleigh, L. On Reflection of Vibrations at the Confines of two Media between which the Transition is Gradual. Proc. Lond. Math. Soc. 1879, 1, 51-56. [CrossRef]

44. Fink, Y. A Dielectric Omnidirectional Reflector. Science 1998, 282, 1679-1682. [CrossRef]

45. Dobrowolski, J.A.; Piotrowski, S.H.C. Refractive index as a variable in the numerical design of optical thin film systems. Appl. Opt. 1982, 21, 1502. [CrossRef]

46. Cox, J.T.; Hass, G. Antireflection coatings for optical and infrared materials. In Physics of Thin Films; Academic Press: New York, NY, USA, 1968; Volume 2, p. 239.

47. San Vicente, G.; Morales, A.; German, N.; Suarez, S.; Sanchez, B. SiO2/TiO2 Antireflective Coatings with Photocatalytic Properties Prepared by Sol-Gel for Solar Glass Covers. J. Sol. Energy Eng. 2012, 134, 041011. [CrossRef]

48. Bouhafs, D. Design and simulation of antireflection coating systems for optoelectronic devices: Application to silicon solar cells. Sol. Energy Mater. Sol. Cells 1998, 52, 79-93. [CrossRef]

49. Jacobsson, R. Progress in Optics; Wolf, E., Ed.; North-Holland Publishing Company: Amsterdam, The Netherlands, 1966; Volume 5, p. 247.

50. Sheldon, B.; Haggerty, J.S.; Emslie, A.G. Exact computation of the reflectance of a surface layer of arbitrary refractive-index profile and an approximate solution of the inverse problem. J. Opt. Soc. Am. 1982, 72, 1049. [CrossRef]

51. Southwell, W.H. Gradient-index antireflection coatings. Opt. Lett. 1983, 8, 584. [CrossRef]

52. Spiller, E.; Haller, I.; Feder, R.; Baglin, J.E.E.; Hammer, W.N. Graded-index AR surfaces produced by ion implantation on plastic materials. Appl. Opt. 1980, 19, 3022. [CrossRef]

53. Yeh, P.; Sari, S. Optical properties of stratified media with exponentially graded refractive index. Appl. Opt. 1983, 22, 4142. [CrossRef] 
54. Verly, P.G.; Dobrowolski, J.A.; Willey, R.R. Fourier-transform method for the design of wideband antireflection coatings. Appl. Opt. 1992, 31, 3836. [CrossRef]

55. Grann, E.B.; Moharam, M.G.; Pommet, D.A. Optimal design for antireflective tapered two-dimensional subwavelength grating structures. J. Opt. Soc. Am. A 1995, 12, 333. [CrossRef]

56. Zhou, W.; Tao, M.; Chen, L.; Yang, H. Microstructured surface design for omnidirectional antireflection coatings on solar cells. J. Appl. Phys. 2007, 102, 103105. [CrossRef]

57. Xi, J.-Q.; Schubert, M.F.; Kim, J.K.; Schubert, E.F.; Chen, M.; Lin, S.-Y.; Liu, W.; Smart, J.A. Optical thin-film materials with low refractive index for broadband elimination of Fresnel reflection. Nat. Photonics 2007, 1, 176-179. [CrossRef]

58. Gombert, A.; Glaubitt, W.; Rose, K.; Dreibholz, J.; Blasi, B.; Heinzel, A.; Sporn, D.; Doll, W.; Wittwer, V. Subwavelength-structured antireflective surfaces on glass. Thin Solid Film 1999, 351, 73-78. [CrossRef]

59. Bernhard, C.G. Structural and functional adaptation in a visual system. Endeavour 1967, 26, 79-84.

60. Clapham, P.B.; Hutley, M.C. Reduction of Lens Reflexion by the "Moth Eye" Principle. Nature 1973, 244, 281-282. [CrossRef]

61. Nicoll, F.H. A New Chemical Method of Reducing the Reflectance of Glass. RCA Rev. 1942, 6, 287.

62. Nicoll, F.H.; Williams, F.E. Properties of Low Reflection Films Produced by the Action of Hydrofluoric Acid Vapor. J. Opt. Soc. Am. 1943, 33, 434. [CrossRef]

63. Monaco, S.F. Reflectance of an Inhomogeneous Thin Film. J. Opt. Soc. Am. 1961, 51, 280. [CrossRef]

64. Minot, M.J. The angluar reflectance of single-layer gradient refractive-index films. J. Opt. Soc. Am. 1977, 67, 1046. [CrossRef]

65. Walheim, S.; Walheim, S.; Schaffer, E.; Mlynek, J.; Steiner, U. Nanophase-Separated Polymer Films as High-Performance Antireflection Coatings. Science 1999, 283, 520-522. [CrossRef]

66. Parker, A.R.; Hegedus, Z.; Watts, R.A. Solar-absorber antireflector on the eye of an Eocene fly (45 Ma). Proc. R. Soc. B Biol. Sci. 1998, 265, 811-815. [CrossRef]

67. Craighead, H.G.; Howard, R.E.; Sweeney, J.E.; Tennant, D.M. Textured surfaces: Optical storage and other applications. J. Vac. Sci. Technol. 1982, 20, 316-319. [CrossRef]

68. Gittleman, J.I.; Sichel, E.K.; Lehmann, H.W.; Widmer, R. Textured silicon: A selective absorber for solar thermal conversion. Appl. Phys. Lett. 1979, 35, 742-744. [CrossRef]

69. Craighead, H.G.; Howard, R.E.; Tennant, D.M. Textured thin-film Si solar selective absorbers using reactive ion etching. Appl. Phys. Lett. 1980, 37, 653-655. [CrossRef]

70. Craighead, H.G.; Howard, R.E.; Tennant, D.M. Selectively emissive refractory metal surfaces. Appl. Phys. Lett. 1981, 38, 74-76. [CrossRef]

71. Horwitz, C.M. A new vacuum-etched high-transmittance (antireflection) film. Appl. Phys. Lett. 1980, 36, 727-729. [CrossRef]

72. Deinega, A.; Valuev, I.; Potapkin, B.; Lozovik, Y. Minimizing light reflection from dielectric textured surfaces. J. Opt. Soc. Am. A 2011, 28, 770. [CrossRef]

73. Sopori, B.L.; Pryor, R.A. Design of antireflection coatings for textured silicon solar cells. Sol. Cells 1983, 8, 249-261. [CrossRef]

74. Rao, B.G.; Mukherjee, D.; Reddy, B.M. Chapter 1-Novel approaches for preparation of nanoparticles. In Nanostructures for Novel Therapy; Elsevier: Amsterdam, The Netherlands, 2017; pp. 1-36. [CrossRef]

75. Adachi, H.; Wasa, K. Thin Films and Nanomaterials. Handb. Sputtering Technol. 2012, 3-39.

76. Levy, F. Film Growth and Epitaxy: Methods. In Reference Module in Materials Science and Materials Engineering; Elsevier: Amsterdam, The Netherlands, 2016. [CrossRef]

77. Zaier, A.; Meftah, A.; Jaber, A.Y.; Abdelaziz, A.A.; Aida, M.S. Annealing effects on the structural, electrical and optical properties of $\mathrm{ZnO}$ thin films prepared by thermal evaporation technique. J. King Saud Univ. Sci. 2015, 27, 356-360. [CrossRef]

78. Wang, Z.; Yao, N.; Hu, X. Single material TiO2 double layers antireflection coating with photocatalytic property prepared by magnetron sputtering technique. Vacuum 2014, 108, 20-26. [CrossRef]

79. Hawkeye, M.M.; Brett, M.J. Glancing angle deposition: Fabrication, properties, and applications of microand nanostructured thin films. J. Vac. Sci. Technol. A Vac. Surf. Film. 2007, 25, 1317. [CrossRef]

80. Kiema, G.K.; Colgan, M.J.; Brett, M.J. Dye sensitized solar cells incorporating obliquely deposited titanium oxide layers. Sol. Energy Mater. Sol. Cells 2005, 85, 321-331. [CrossRef] 
81. Kennedy, S.R.; Brett, M.J. Porous broadband antireflection coating by glancing angle deposition. Appl. Opt. 2003, 42, 4573. [CrossRef]

82. Martinu, L.; Poitras, D. Plasma deposition of optical films and coatings: A review. J. Vac. Sci. Technol. A 2000, 18, 2619-2645. [CrossRef]

83. Remache, L.; Fourmond, E.; Mahdjoub, A.; Dupuis, J.; Lemiti, M. Design of porous silicon/PECVD SiOx antireflection coatings for silicon solar cells. Mater. Sci. Eng. B 2011, 176, 45-48. [CrossRef]

84. Neuman, G.A. Anti-reflective coatings by APCVD using graded index layers. J. Non Cryst. Solids 1997, 218, 92-99. [CrossRef]

85. Dorey, R. Chapter 5-Patterning: How to go from a coating to a shape. In Ceramic Thick Films for MEMS and Microdevices; Elsevier: Amsterdam, The Netherlands, 2012; pp. 113-143.

86. Koynov, S.; Brandt, M.S.; Stutzmann, M. Black nonreflecting silicon surfaces for solar cells. Appl. Phys. Lett. 2006, 88, 203107. [CrossRef]

87. Papet, P.; Nichiporuk, O.; Kaminski, A.; Rozier, Y.; Kraiem, J.; Lelievre, J.-F.; Chaumartin, A.; Fave, A.; Lemiti, M. Pyramidal texturing of silicon solar cell with TMAH chemical anisotropic etching. Sol. Energy Mater. Sol. Cells 2006, 90, 2319-2328. [CrossRef]

88. Zhao, J.; Wang, A.; Green, M.A. 2nd World Conference on Photovoltaic Solar Energy Conversion. In Proceedings of the International Conference, Vienna, Austria, 6-10 July 1998.

89. Shultz, O.; Emanuel, G.; Glunz, S.W.; Willeke, G.P. Texturing of multicrystalline silicon with acidic wet chemical etching and plasma etching. In Proceedings of the 3rd World Conference on Photovoltaic Solar Energy Conversion, Osaka, Japan, 12-18 May 2003; pp. 1360-1363.

90. Acikgoz, C.; Hempenius, M.A.; Huskens, J.; Vancso, G.J. Polymers in conventional and alternative lithography for the fabrication of nanostructures. Eur. Polym. J. 2011, 47, 2033-2052. [CrossRef]

91. Zhou, S.; Hu, M.; Guo, Q.; Cai, X.; Xu, X.; Yang, J. Solvent-transfer assisted photolithography of high-density and high-aspect-ratio superhydrophobic micropillar arrays. J. Micromech. Microeng. 2015, 25, 025005. [CrossRef]

92. Kooy, N.; Mohamed, K.; Pin, L.; Guan, O. A review of roll-to-roll nanoimprint lithography. Nanoscale Res. Lett. 2014, 9, 320. [CrossRef] [PubMed]

93. Han, K.-S.; Shin, J.-H.; Yoon, W.-Y.; Lee, H. Enhanced performance of solar cells with anti-reflection layer fabricated by nano-imprint lithography. Sol. Energy Mater. Sol. Cells 2011, 95, 288-291. [CrossRef]

94. Lim, J.H.; Leem, J.W.; Yu, J.S. Solar power generation enhancement of dye-sensitized solar cells using hydrophobic and antireflective polymers with nanoholes. RSC Adv. 2015, 5, 61284-61289. [CrossRef]

95. Ibn-Elhaj, M.; Schadt, M. Optical polymer thin films with isotropic and anisotropic nano-corrugated surface topologies. Nature 2001, 410, 796-799. [CrossRef]

96. Maier, T.; Bach, D.; Mullner, P.; Hainberger, R.; Bruckl, H. Antireflective surface structures in glass by self-assembly of $\mathrm{SiO} 2$ nanoparticles and wet etching. Opt. Express 2013, 21, 20254. [CrossRef]

97. Ji, S.; Song, K.; Nguyen, T.B.; Kim, N.; Lim, H. Optimal Moth Eye Nanostructure Array on Transparent Glass Towards Broadband Antireflection. Acs Appl. Mater. Interfaces 2013, 5, 10731-10737. [CrossRef]

98. Park, K.-C.; Choi, H.J.; Chang, C.-H.; Cohen, R.E.; McKinley, G.H.; Barbastathis, G. Nanotextured Silica Surfaces with Robust Superhydrophobicity and Omnidirectional Broadband Supertransmissivity. ACS Nano 2012, 6, 3789-3799. [CrossRef]

99. Mahadik, D.B.; Lakshmi, R.V.; Barshilia, H.C. High performance single layer nano-porous antireflection coatings on glass by sol-gel process for solar energy applications. Sol. Energy Mater. Sol. Cells 2015, 140, 61-68. [CrossRef]

100. Nagel, H.; Metz, A.; Hezel, R. Porous SiO2 films prepared by remote plasma-enhanced chemical vapour deposition - a novel antireflection coating technology for photovoltaic modules. Sol. Energy Mater. Sol. Cells 2001, 65, 71-77. [CrossRef]

101. Zhao, J.; Wang, A.; Altermatt, P.; Green, M.A. Twenty-four percent efficient silicon solar cells with double layer antireflection coatings and reduced resistance loss. Appl. Phys. Lett. 1995, 66, 3636-3638. [CrossRef]

102. Strehlke, S.; Bastide, S.; Guillet, J.; Levy-Clement, C. Design of porous silicon antireflection coatings for silicon solar cells. Mater. Sci. Eng. B 2000,69-70, 81-86. [CrossRef]

103. Lipinski, M.; Panek, P.; Bełtowska, E.; Czternastek, H. Reduction of surface reflectivity by using double porous silicon layers. Mater. Sci. Eng. B 2003, 101, 297-299. [CrossRef] 
104. Wang, N.; Fang, J.; Zhang, X.; Wang, G.; Wang, L.; Liu, C.; Zhao, H.; Chen, Z.; Chen, X.L.; Sun, J.; et al. Combined $\mathrm{SiO} 2$ antireflective coatings with MOCVD-ZnO:B to improve light absorption in thin-film solar cells. Sol. Energy Mater. Sol. Cells 2014, 130, 420-425. [CrossRef]

105. Cao, H.; Bai, Y.; Qiao, L. Antireflection effect of $\mathrm{SiO} 2$ thin film on the pyramidal textured surface of monocrystalline silicon. Opt. Int. J. Light Electron Opt. 2015, 126, 2643-2645. [CrossRef]

106. Guo, Z.Q.; Liu, Y.; Tang, M.Y.; Wang, J.H.; Su, X.P. Super-durable closed-surface antireflection thin film by silica nanocomposites. Sol. Energy Mater. Sol. Cells 2017, 170, 143-148. [CrossRef]

107. Agustin-Saenz, C.; Sanchez-Garcia, J.A.; Machado, M.; Brizuela, M.; Zubillaga, O.; Tercjak, A. Broadband antireflective coating stack based on mesoporous silica by acid-catalyzed sol-gel method for concentrated photovoltaic application. Sol. Energy Mater. Sol. Cells 2018, 186, 154-164. [CrossRef]

108. Liu, H.-C.; Wang, G.-J. Fabrication of high anti-reflection nanowires on silicon using two-stage metal-assisted etching. J. Renew. Sustain. Energy 2013, 5, 053115. [CrossRef]

109. Li, X. Metal assisted chemical etching for high aspect ratio nanostructures: A review of characteristics and applications in photovoltaics. Curr. Opin. Solid State Mater. Sci. 2012, 16, 71-81. [CrossRef]

110. Jung, J.-Y.; Guo, Z.; Jee, S.-W.; Um, H.-D.; Park, K.-T.; Hyun, M.S.; Yang, J.M.; Lee, J.-H. A waferscale Si wire solar cell using radial and bulk p-n junctions. Nanotechnology 2010, 21, 445303. [CrossRef]

111. Li, S.; Ma, W.; Chen, X.; Xie, K.; Li, Y.; He, X.; Yang, X.; Lei, Y. Structure and antireflection properties of SiNWs arrays form mc-Si wafer through Ag-catalyzed chemical etching. Appl. Surf. Sci. 2016, 369, 232-240. [CrossRef]

112. Nielsen, K.H.; Orzol, D.K.; Koynov, S.; Carney, S.; Hultstein, E.; Wondraczek, L. Large area, low cost anti-reflective coating for solar glasses. Sol. Energy Mater. Sol. Cells 2014, 128, 283-288. [CrossRef]

113. Van de Groep, J.; Spinelli, P.; Polman, A. Single-Step Soft-Imprinted Large-Area Nanopatterned Antireflection Coating. Nano Lett. 2015, 15, 4223-4228. [CrossRef] [PubMed]

114. Sobahan, K.M.A.; Park, Y.J.; Kim, J.J.; Hwangbo, C.K. Nanostructured porous SiO2 films for antireflection coatings. Opt. Commun. 2011, 284, 873-876. [CrossRef]

115. Jia, G.; Ji, Z.; Wang, H.; Chen, R. Preparation and properties of five-layer graded-refractive-index antireflection coating nanostructured by solid and hollow silica particles. Thin Solid Film 2017, 642, 174-181. [CrossRef]

116. Zhi, J.; Zhang, L.-Z. Durable superhydrophobic surface with highly antireflective and self-cleaning properties for the glass covers of solar cells. Appl. Surf. Sci. 2018, 454, 239-248. [CrossRef]

117. Chi, F.; Liu, D.; Wu, H.; Lei, J. Mechanically robust and self-cleaning antireflection coatings from nanoscale binding of hydrophobic silica nanoparticles. Sol. Energy Mater. Sol. Cells 2019, 200, 109939. [CrossRef]

118. Liang, Z.; Li, W.; Dong, B.; Sun, Y.; Tang, H.; Zhao, L.; Wang, S. Double-function SiO2-DMS coating with antireflection and superhydrophobic surface. Chem. Phys. Lett. 2019, 716, 211-214. [CrossRef]

119. Luo, Q.; Deng, X.; Zhang, C.; Yu, M.; Zhou, X.; Wang, Z.; Chen, X.; Huang, S. Enhancing photovoltaic performance of perovskite solar cells with silica nanosphere antireflection coatings. Sol. Energy 2018, 169, 128-135. [CrossRef]

120. Li, D.; Han, S.; Li, A.; Wang, Y.; Shan, Y.; Huang, F. Novel-type nanostructured SiO2 antireflection coatings and their application in $\mathrm{Cu}(\mathrm{In}, \mathrm{Ga}) \mathrm{Se} 2$ solar cells. Mater. Chem. Phys. 2015, 165, 97-102. [CrossRef]

121. Wang, D.; Yang, Z.; Li, F.; Liu, D.; Wang, P.; He, D. Broadband antireflection of silicon nanorod arrays prepared by plasma enhanced chemical vapor deposition. Appl. Surf. Sci. 2011, 258, 1058-1061. [CrossRef]

122. Duttagupta, S.; Ma, F.; Hoex, B.; Mueller, T.; Aberle, A.G. Optimised Antireflection Coatings using Silicon Nitride on Textured Silicon Surfaces based on Measurements and Multidimensional Modelling. Energy Procedia 2012, 15, 78-83. [CrossRef]

123. Prasad, B.; Bhattacharya, S.; Saxena, A.K.; Reddy, S.R.; Bhogra, R.K. Performance enhancement of mc-Si solar cells due to synergetic effect of plasma texturization and SiNx:H AR coating. Sol. Energy Mater. Sol. Cells 2010, 94, 1329-1332. [CrossRef]

124. Yoshioka, K.; Minami, Y.; Shudo, K.; Dao, T.D.; Nagao, T.; Kitajima, M.; Takeda, J.; Katayama, I. Terahertz-Field-Induced Nonlinear Electron Delocalization in Au Nanostructures. Nano Lett. 2015, 15, 1036-1040. [CrossRef] [PubMed]

125. De Zuani, S.; Rommel, M.; Gompf, B.; Berrier, A.; Weis, J.; Dressel, M. Suppressed Percolation in Nearly Closed Gold Films. ACS Photonics 2016, 3, 1109-1115. [CrossRef]

126. Fan, P.; Bai, B.; Jin, G.; Zhang, H.; Zhong, M. Patternable fabrication of hyper-hierarchical metal surface structures for ultrabroadband antireflection and self-cleaning. Appl. Surf. Sci. 2018, 457, 991-999. [CrossRef] 
127. Teperik, T.V.; García de Abajo, F.J.; Borisov, A.G.; Abdelsalam, M.; Bartlett, P.N.; Sugawara, Y.; Baumberg, J.J. Omnidirectional absorption in nanostructured metal surfaces. Nat. Photonics 2008, 2, 299-301. [CrossRef]

128. Raza, S.; Stenger, N.; Pors, A.; Holmgaard, T.; Kadkhodazadeh, S.; Wagner, J.B.; Pedersen, K.; Wubs, M.; Bozhevolnyi, S.I.; Mortensen, N.A. Extremely confined gap surface-plasmon modes excited by electrons. Nat. Commun. 2014, 5, 4125. [CrossRef]

129. Ding, L.; Wu, Q.Y.S.; Teng, J.H. Polarization independent broadband terahertz antireflection by deep-subwavelength thin metallic mesh. Laser Photonics Rev. 2014, 8, 941-945. [CrossRef]

130. Xu, S.-T.; Hu, F.-T.; Chen, M.; Fan, F.; Chang, S.-J. Broadband Terahertz Polarization Converter and Asymmetric Transmission Based on Coupled Dielectric-Metal Grating. Ann. Der Phys. 2017, 529, 1700151. [CrossRef]

131. Toma, M.; Loget, G.; Corn, R.M. Fabrication of Broadband Antireflective Plasmonic Gold Nanocone Arrays on Flexible Polymer Films. Nano Lett. 2013, 13, 6164-6169. [CrossRef] [PubMed]

132. Kern, W.; Tracy, E. Titanium dioxide antireflection coating for silicon solar cells by spray deposition. RCA Rev. 1980, 41, 133-180.

133. Shinde, P.; Sadale, S.; Patil, P.; Bhosale, P.; Bruger, A.; Neumann-spallart, M.; Bhosale, C. Properties of spray deposited titanium dioxide thin films and their application in photoelectrocatalysis. Sol. Energy Mater. Sol. Cells 2008, 92, 283-290. [CrossRef]

134. Zallen, R.; Moret, M.P. The optical absorption edge of brookite TiO2. Solid State Commun. 2006, 137, $154-157$. [CrossRef]

135. Richards, B.S.; Cotter, J.E.; Honsberg, C.B.; Wenham, S.R. Novel uses of TiO2 in crystalline silicon solar cells. In Proceedings of the 28th IEEE Photovoltaic Specialists Conference, Anchorage, AK, USA, 15-22 September 2000; pp. 375-378.

136. Pore, V.; Rahtu, A.; Leskela, M.; Ritala, M.; Sajavaara, T.; Keinonen, J. Atomic Layer Deposition of Photocatalytic TiO2 Thin Films from Titanium Tetramethoxide and Water. Chem. Vap. Depos. 2004, 10, 143-148. [CrossRef]

137. Yamauchi, S.; Saiki, S.; Ishibashi, K.; Nakagawa, A.; Hatakeyama, S. Low Pressure Chemical Vapor Deposition of $\mathrm{Nb}$ and F Co-Doped TiO2 Layer. J. Cryst. Process Technol. 2014, 4, 79-88. [CrossRef]

138. Kafizas, A.; Noor, N.; Carmichael, P.; Scanlon, D.O.; Carmalt, C.J.; Parkin, I.P. Combinatorial Atmospheric Pressure Chemical Vapor Deposition of F:TiO2; the Relationship between Photocatalysis and Transparent Conducting Oxide Properties. Adv. Funct. Mater. 2013, 24, 1758-1771. [CrossRef]

139. Dan, Y.; Seo, K.; Takei, K.; Meza, J.H.; Javey, A.; Crozier, K.B. Dramatic Reduction of Surface Recombination by in Situ Surface Passivation of Silicon Nanowires. Nano Lett. 2011, 11, 2527-2532. [CrossRef]

140. Giannakopoulou, T.; Todorova, N.; Vaimakis, T.; Ladas, S.; Trapalis, C. Study of Fluorine-Doped TiO2 Sol-Gel Thin Coatings. J. Sol. Energy Eng. 2008, 130, 041007. [CrossRef]

141. Leyland, N.S.; Podporska-Carroll, J.; Browne, J.; Hinder, S.J.; Quilty, B.; Pillai, S.C. Highly Efficient F, Cu doped $\mathrm{TiO} 2$ anti-bacterial visible light active photocatalytic coatings to combat hospital-acquired infections. Sci. Rep. 2016, 6, 24770. [CrossRef]

142. Li, D.; Haneda, H.; Hishita, S.; Ohashi, N.; Labhsetwar, N.K. Fluorine-doped TiO2 powders prepared by spray pyrolysis and their improved photocatalytic activity for decomposition of gas-phase acetaldehyde. J. Fluor. Chem. 2005, 126, 69-77. [CrossRef]

143. Yu, J.; Yang, Y.-L.; Fan, R.-Q.; Li, L.; Wei, L.-G. Mechanism of performance enhancement via fluorine doped titanium dioxide nanoparticles in dye sensitized solar cells. J. Fluor. Chem. 2015, 176, 71-77. [CrossRef]

144. Ren, G.; Gao, Y.; Liu, X.; Xing, A.; Liu, H.; Yin, J. Synthesis of high-activity F-doped TiO2 photocatalyst via a simple one-step hydrothermal process. Reaction Kinetics. Mech. Catal. 2010, 100, 487-497.

145. Ho, W.; Yu, J.C.; Lee, S. Synthesis of hierarchical nanoporous F-doped TiO2 spheres with visible light photocatalytic activity. Chem. Commun. 2006, 100, 1115. [CrossRef] [PubMed]

146. Maki, H.; Okumura, Y.; Ikuta, H.; Mizuhata, M. Ionic Equilibria for Synthesis of TiO2 Thin Films by the Liquid-Phase Deposition. J. Phys. Chem. C 2014, 118, 11964-11974. [CrossRef]

147. Hocine, D.; Belkaid, M.S.; Pasquinelli, M.; Escoubas, L.; Simon, J.J.; Riviere, G.A.; Moussi, A. Improved efficiency of multicrystalline silicon solar cells by $\mathrm{TiO} 2$ antireflection coatings derived by APCVD process. Mater. Sci. Semicond. Process. 2013, 16, 113-117. [CrossRef]

148. Yu, J.; Chary, S.; Das, S.; Tamelier, J.; Pesika, N.S.; Turner, K.L.; Israelachvili, J.N. Gecko-Inspired Dry Adhesive for Robotic Applications. Adv. Funct. Mater. 2011, 21, 3010-3018. [CrossRef] 
149. Prabhu, S.; Cindrella, L.; Joong Kwon, O.; Mohanraju, K. Superhydrophilic and self-cleaning rGO-TiO2 composite coatings for indoor and outdoor photovoltaic applications. Sol. Energy Mater. Sol. Cells 2017, 169, 304-312. [CrossRef]

150. Adak, D.; Ghosh, S.; Chakraborty, P.; Srivatsa, K.M.K.; Mondal, A.; Saha, H.; Mukherjee, R.; Bhattacharyya, R. Non lithographic block copolymer directed self-assembled and plasma treated self-cleaning transparent coating for photovoltaic modules and other solar energy devices. Sol. Energy Mater. Sol. Cells 2018, 188, 127-139. [CrossRef]

151. Haider, A.J.; Najim, A.A.; Muhi, M.A.H. TiO2/Ni composite as antireflection coating for solar cell application. Opt. Commun. 2016, 370, 263-266. [CrossRef]

152. Huang, J.-J.; Lin, C.-C.; Wuu, D.-S. Antireflection and passivation property of titanium oxide thin film on silicon nanowire by liquid phase deposition. Surf. Coat. Technol. 2017, 320, 252-258. [CrossRef]

153. Visniakov, J.; Janulevicius, A.; Maneikis, A.; Matulaitiene, I.; Selskis, A.; Stanionyte, S.; Suchodolskis, A. Antireflection TiO 2 coatings on textured surface grown by HiPIMS. Thin Solid Film 2017, 628, 190-195. [CrossRef]

154. Richards, B.S. Single-material TiO2 double-layer antireflection coatings. Sol. Energy Mater. Sol. Cells 2003, 79, 369-390. [CrossRef]

155. Kim, S.; Koh, J.H.; Yang, X.; Chi, W.S.; Park, C.; Leem, J.W.; Kim, B.; Seo, S.; Kim, Y.; Yu, J.S.; et al. Enhanced Device Efficiency of Bilayered Inverted Organic Solar Cells Based on Photocurable P3HTs with a Light-Harvesting ZnO Nanorod Array. Adv. Energy Mater. 2013, 4, 1301338. [CrossRef]

156. Hsueh, H.-T.; Chen, Y.-H.; Lin, Y.-D.; Lai, K.-C.; Chen, J.-W.; Wu, C.-L. Integration of flower-like ZnO nanostructures with crystalline-Si interdigitated back contact photovoltaic cell as a self-powered humidity sensor. Appl. Phys. Lett. 2013, 103, 213109. [CrossRef]

157. Lee, J.W.; Ye, B.U.; Kim, D.; Kim, J.K.; Heo, J.; Jeong, H.Y.; Kim, M.H.; Choi, W.J.; Baik, J.M. ZnO Nanowire-Based Antireflective Coatings with Double-Nanotextured Surfaces. ACS Appl. Mater. Interfaces 2014, 6, 1375-1379. [CrossRef]

158. Dalvand, R.; Mahmud, S.; Rouhi, J.; Raymond Ooi, C.H. Well-aligned ZnO nanoneedle arrays grown on polycarbonate substrates via electric field-assisted chemical method. Mater. Lett. 2015, 146, 65-68. [CrossRef]

159. Leem, J.W.; Kim, S.; Park, C.; Kim, E.; Yu, J.S. Strong Photocurrent Enhancements in Plasmonic Organic Photovoltaics by Biomimetic Nanoarchitectures with Efficient Light Harvesting. ACS Appl. Mater. Interfaces 2015, 7, 6706-6715. [CrossRef]

160. Dogar, S.; Khan, W.; Kim, S.-D. Ultraviolet photoresponse of ZnO nanostructured AlGaN/GaN HEMTs. Mater. Sci. Semicond. Process. 2016, 44,71-77. [CrossRef]

161. So, H.; Senesky, D.G. ZnO nanorod arrays and direct wire bonding on GaN surfaces for rapid fabrication of antireflective, high-temperature ultraviolet sensors. Appl. Surf. Sci. 2016, 387, 280-284. [CrossRef]

162. Agarwal, D.C.; Chauhan, R.S.; Avasthi, D.K.; Sulania, I.; Kabiraj, D.; Thakur, P.; Chae, K.H.; Chawla, A.; Chandra, R.; Ogale, S.B.; et al. VLS-like growth and characterizations of dense ZnO nanorods grown by e-beam process. J. Phys. D Appl. Phys. 2009, 42, 035310. [CrossRef]

163. Poornajar, M.; Marashi, P.; Haghshenas Fatmehsari, D.; Kolahdouz Esfahani, M. Synthesis of ZnO nanorods via chemical bath deposition method: The effects of physicochemical factors. Ceram. Int. 2016, 42, 173-184. [CrossRef]

164. Zhao, Y.; Li, C.; Chen, M.; Yu, X.; Chang, Y.; Chen, A.; Zhu, H.; Tang, Z. Growth of aligned ZnO nanowires via modified atmospheric pressure chemical vapor deposition. Phys. Lett. A 2016, 380, 3993-3997. [CrossRef]

165. Yin, Y.T.; Que, W.X.; Kam, C.H. ZnO nanorods on ZnO seed layer derived by sol-gel process. J. Sol Gel Sci. Technol. 2009, 53, 605-612. [CrossRef]

166. Liu, B.; Zeng, H.C. Hydrothermal Synthesis of ZnO Nanorods in the Diameter Regime of $50 \mathrm{~nm}$. J. Am. Chem. Soc. 2003, 125, 4430-4431. [CrossRef] [PubMed]

167. Yang, J.; Zheng, J.; Zhai, H.; Yang, X.; Yang, L.; Liu, Y.; Lang, J.; Gao, M. Oriented growth of ZnO nanostructures on different substrates via a hydrothermal method. J. Alloy Compd. 2010, 489, 51-55. [CrossRef]

168. Nowak, R.-E.; Vehse, M.; Sergeev, O.; Voss, T.; Seyfried, M.; von Maydell, K.; Agert, C. ZnO Nanorods with Broadband Antireflective Properties for Improved Light Management in Silicon Thin-Film Solar Cells. Adv. Opt. Mater. 2013, 2, 94-99. [CrossRef]

169. Chung, R.-J.; Lin, Z.-C.; Lin, C.-A.; Lai, K.-Y. Study of an antireflection surface constructed of controlled ZnO nanostructures. Thin Solid Film 2014, 570, 504-509. [CrossRef] 
170. Makableh, Y.F.; Vasan, R.; Sarker, J.C.; Nusir, A.I.; Seal, S.; Manasreh, M.O. Enhancement of GaAs solar cell performance by using a ZnO sol-gel anti-reflection coating. Sol. Energy Mater. Sol. Cells 2014, 123, 178-182. [CrossRef]

171. Qu, Y.; Huang, X.; Li, Y.; Lin, G.; Guo, B.; Song, D.; Cheng, Q. Chemical bath deposition produced ZnO nanorod arrays as an antireflective layer in the polycrystalline Si solar cells. J. Alloy Compd. 2017, 698, 719-724. [CrossRef]

172. Lin, Z.; Huang, B.; He, G.; Yang, W.; He, Q.; Li, L. High efficiency enhancement of multi-crystalline silicon solar cells with syringe-shaped $\mathrm{ZnO}$ nanorod antireflection layers. Thin Solid Film 2018, 653, 151-157. [CrossRef]

173. Fernandez, S.; Gandia, J.J. Texture optimization process of $\mathrm{ZnO}: \mathrm{Al}$ thin films using $\mathrm{NH} 4 \mathrm{Cl}$ aqueous solution for applications as antireflective coating in thin film solar cells. Thin Solid Film 2012, 520, 4698-4702. [CrossRef]

174. Yun, J.-H.; Lee, E.; Park, H.-H.; Kim, D.-W.; Anderson, W.A.; Kim, J.; Litchinitser, N.M.; Zeng, J.; Yi, J.; Kumar, M.M.D.; et al. Incident light adjustable solar cell by periodic nanolens architecture. Sci. Rep. 2014, 4, 6879. [CrossRef]

175. Ham, J.; Park, J.Y.; Dong, W.J.; Jung, G.H.; Yu, H.K.; Lee, J.-L. Antireflective indium-tin-oxide nanobranches for efficient organic solar cells. Appl. Phys. Lett. 2016, 108, 073903. [CrossRef]

176. Tien, W.C.; Chu, A.K. Double-layer ITO antireflection electrodes fabricated at low temperature. Sol. Energy Mater. Sol. Cells 2012, 100, 258-262. [CrossRef]

177. Rubio, F.; Denis, J.; Albella, J.M.; Martinez-Duart, J.M. Sputtered Ta2O5 antireflection coatings for silicon solar cells. Thin Solid Film 1982, 90, 405-408. [CrossRef]

178. Rubio, F.; Dennis, J.; Albella, J.M.; Martinez-Duart, J.M. Reactive sputtered Ta2O5 antireflection coatings. Sol. Cells 1983, 8, 263-268. [CrossRef]

179. Fujihara, S.; Tada, M.; Kimura, T. Controlling Factors for the Conversion of Trifluoroacetate Sols into Thin Metal Fluoride Coatings. J. Sol Gel Sci. Technol. 2000, 19, 311-314. [CrossRef]

180. Bass, J.D.; Boissiere, C.; Nicole, L.; Grosso, D.; Sanchez, C. Thermally Induced Porosity in CSD MgF2-Based Optical Coatings: An Easy Method to Tune the Refractive Index. Chem. Mater. 2008, 20, 5550-5556. [CrossRef]

181. Noack, J.; Emmerling, F.; Kirmse, H.; Kemnitz, E. Sols of nanosized magnesium fluoride: Formation and stabilisation of nanoparticles. J. Mater. Chem. 2011, 21, 15015. [CrossRef]

182. Sevonkaev, I.; Matijevic, E. Formation of Magnesium Fluoride Particles of Different Morphologies. Langmuir 2009, 25, 10534-10539. [CrossRef] [PubMed]

183. Nandiyanto, A.B.D.; Ogi, T.; Okuyama, K. Control of the Shell Structural Properties and Cavity Diameter of Hollow Magnesium Fluoride Particles. ACS Appl. Mater. Interfaces 2014, 6, 4418-4427. [CrossRef] [PubMed]

184. Cao, M.; Wang, Y.; Qi, Y.; Guo, C.; Hu, C. Synthesis and characterization of MgF2 and KMgF3 nanorods. J. Solid State Chem. 2004, 177, 2205-2209. [CrossRef]

185. Chandra Sekhar Reddy, K.; Karthik, D.; Bhanupriya, D.; Ganesh, K.; Ramakrishna, M.; Sakthivel, S. Broad band antireflective coatings using novel in-situ synthesis of hollow MgF2 nanoparticles. Sol. Energy Mater. Sol. Cells 2018, 176, 259-265. [CrossRef]

186. Karthik, D.; Pendse, S.; Sakthivel, S.; Ramasamy, E.; Joshi, S.V. High performance broad band antireflective coatings using a facile synthesis of ink-bottle mesoporous $\mathrm{MgF} 2$ nanoparticles for solar applications. Sol. Energy Mater. Sol. Cells 2017, 159, 204-211. [CrossRef]

187. Pendse, S.; Chandra Sekhar Reddy, K.; Narendra, C.; Murugan, K.; Sakthivel, S. Dual-functional broadband antireflective and hydrophobic films for solar and optical applications. Sol. Energy 2018, 163, 425-433. [CrossRef]

188. Shin, B.-K.; Lee, T.-I.; Xiong, J.; Hwang, C.; Noh, G.; Cho, J.-H.; Myoung, J.-M. Bottom-up grown ZnO nanorods for an antireflective moth-eye structure on CuInGaSe2 solar cells. Sol. Energy Mater. Sol. Cells 2011, 95, 2650-2654. [CrossRef]

189. Scholtz, L.; Sutta, P.; Calta, P.; Novak, P.; Solanska, M.; Mullerova, J. Investigation of barium titanate thin films as simple antireflection coatings for solar cells. Appl. Surf. Sci. 2018, 461, 249-254. [CrossRef]

190. Chen, Y.-C.; Huang, Z.-S.; Yang, H. Cicada-Wing-Inspired Self-Cleaning Antireflection Coatings on Polymer Substrates. ACS Appl. Mater. Interfaces 2015, 7, 25495-25505. [CrossRef] 
191. Kwon, Y.W.; Park, J.; Kim, T.; Kang, S.H.; Kim, H.; Shin, J.; Jeon, S.; Hong, S.W. Flexible Near-Field Nanopatterning with Ultrathin, Conformal Phase Masks on Nonplanar Substrates for Biomimetic Hierarchical Photonic Structures. ACS Nano 2016, 10, 4609-4617. [CrossRef]

192. Dudem, B.; Heo, J.H.; Leem, J.W.; Yu, J.S.; Im, S.H. CH3NH3PbI3 planar perovskite solar cells with antireflection and self-cleaning function layers. J. Mater. Chem. A 2016, 4, 7573-7579. [CrossRef]

193. Choi, K.; Park, S.H.; Song, Y.M.; Lee, Y.T.; Hwangbo, C.K.; Yang, H.; Lee, H.S. Nano-tailoring the Surface Structure for the Monolithic High-Performance Antireflection Polymer Film. Adv. Mater. 2010, 22, 3713-3718. [CrossRef] [PubMed]

194. Leem, J.W.; Dudem, B.; Yu, J.S. Thermal-tolerant polymers with antireflective and hydrophobic grooved subwavelength grating surfaces for high-performance optics. RSC Adv. 2016, 6, 79755-79762. [CrossRef]

195. Kumar, A.; Yerva, S.V.; Barshilia, H.C. Broadband and wide angle anti-reflective nanoporous surface on poly (ethylene terephthalate) substrate using a single step plasma etching for applications in flexible electronics. Sol. Energy Mater. Sol. Cells 2016, 155, 184-193. [CrossRef]

196. Jun, J.; Lee, J.-H.; Choi, H.-J.; Moon, S.; Kim, I.-D.; Lee, H. Fabrication of optically-functionalized colorless polyimide patterns with high durability. Appl. Surf. Sci. 2017, 423, 881-886. [CrossRef]

197. Xie, H.; Huang, H.-X.; Peng, Y.-J. Rapid fabrication of bio-inspired nanostructure with hydrophobicity and antireflectivity on polystyrene surface replicating from cicada wings. Nanoscale 2017, 9, 11951-11958. [CrossRef]

198. Chou, Y.-Y.; Lee, K.-T.; Lee, Y.-C. Fabrication of hierarchical anti-reflective structures using polystyrene sphere lithography on an as-cut p-Si substrate. Appl. Surf. Sci. 2016, 377, 81-85. [CrossRef]

199. Thiyagu, S.; Devi, B.P.; Pei, Z. Fabrication of large area high density, ultra-low reflection silicon nanowire arrays for efficient solar cell applications. Nano Res. 2011, 4, 1136-1143. [CrossRef]

200. Zhang, Y.; Xuan, Y. Preparation of structured surfaces for full-spectrum photon management in photovoltaic-thermoelectric systems. Sol. Energy Mater. Sol. Cells 2017, 169, 47-55. [CrossRef]

201. Ye, X.; Huang, J.; Zeng, Y.; Sun, L.-X.; Geng, F.; Liu, H.-J.; Wang, F.-R.; Jiang, X.-D.; Wu, W.-D.; Zheng, W.-G. Monolayer Colloidal Crystals by Modified Air-Water Interface Self-Assembly Approach. Nanomaterials 2017, 7, 291. [CrossRef]

202. Li, Y.; Cai, B.; Zhu, Y. Fabrication of anti-reflective micro-structure at terahertz frequency by using Chinese acupuncture needles. Opt. Lett. 2015, 40, 2917. [CrossRef] [PubMed]

203. Chen, J.Y.; Chang, W.-L.; Huang, C.K.; Sun, K.W. Biomimetic nanostructured antireflection coating and its application on crystalline silicon solar cells. Opt. Express 2011, 19, 14411. [CrossRef] [PubMed]

204. Chen, W.; Diao, Z.; Dirks, J.-H.; Geiger, F.; Spatz, J. Enhanced Optical Transmittance by Reduced Reflectance of Curved Polymer Surfaces. Macromol. Mater. Eng. 2017, 302, 1700072. [CrossRef]

205. Liu, Y.; Song, Y.; Niu, S.; Zhang, Y.; Han, Z.; Ren, L. Integrated super-hydrophobic and antireflective PDMS bio-templated from nano-conical structures of cicada wings. RSC Adv. 2016, 6, 108974-108980. [CrossRef]

206. Galeotti, F.; Trespidi, F.; Timo, G.; Pasini, M. Broadband and Crack-Free Antireflection Coatings by Self-Assembled Moth Eye Patterns. ACS Appl. Mater. Interfaces 2014, 6, 5827-5834. [CrossRef] [PubMed]

207. Lin, Y.; Xu, Z.; Yu, D.; Lu, L.; Yin, M.; Tavakoli, M.M.; Chen, X.; Hao, Y.; Fan, Z.; Cui, Y.; et al. Dual-Layer Nanostructured Flexible Thin-Film Amorphous Silicon Solar Cells with Enhanced Light Harvesting and Photoelectric Conversion Efficiency. ACS Appl. Mater. Interfaces 2016, 8, 10929-10936. [CrossRef]

208. Dudem, B.; Ko, Y.H.; Leem, J.W.; Lee, S.H.; Yu, J.S. Highly Transparent and Flexible Triboelectric Nanogenerators with Subwavelength-Architectured Polydimethylsiloxane by a Nanoporous Anodic Aluminum Oxide Template. ACS Appl. Mater. Interfaces 2015, 7, 20520-20529. [CrossRef]

209. Dudem, B.; Jung, J.W.; Yu, J.S. Improved light harvesting efficiency of semitransparent organic solar cells enabled by broadband/omnidirectional subwavelength antireflective architectures. J. Mater. Chem. A 2018, 6, 14769-14779. [CrossRef]

210. Dudem, B.; Ko, Y.H.; Leem, J.W.; Lim, J.H.; Yu, J.S. Hybrid Energy Cell with Hierarchical Nano/Micro-Architectured Polymer Film to Harvest Mechanical, Solar, and Wind Energies Individually/Simultaneously. ACS Appl. Mater. Interfaces 2016, 8, 30165-30175. [CrossRef]

211. Zhang, Y.; Zheng, J.; Fang, C.; Li, Z.; Zhao, X.; Li, Y.; Ruan, X.; Dai, Y. Enhancement of silicon-wafer solar cell efficiency with low-cost wrinkle antireflection coating of polydimethylsiloxane. Sol. Energy Mater. Sol. Cells 2018, 181, 15-20. [CrossRef] 
212. Biswas, K.; Gangopadhyay, S.; Kim, H.-C.; Miller, R.D. Nanoporous organosilicate films as antireflection coatings. Thin Solid Film 2006, 514, 350-354. [CrossRef]

213. Dai, M.; Wang, Y.; Pan, M.; Lin, S.; Rempel, G.L.; Pan, Q. Synthesis and characterization of nanostructured poly(methyl methacrylate) for antireflection coating. Appl. Surf. Sci. 2014, 289, 209-217. [CrossRef]

214. Fang, C.; Yang, Z.; Zhang, J.; Zhuang, Y.; Liu, S.; He, X.; Zhang, Y. Biomimetic diodon-skin nanothorn polymer antireflection film for solar cell applications. Sol. Energy Mater. Sol. Cells 2020, 206, 110305. [CrossRef]

215. Liu, Z.; Zhang, X.; Murakami, T.; Fujishima, A. Sol-gel SiO2/TiO2 bilayer films with self-cleaning and antireflection properties. Sol. Energy Mater. Sol. Cells 2008, 92, 1434-1438. [CrossRef]

216. Lien, S.; Wuu, D.; Yeh, W.; Liu, J. Tri-layer antireflection coatings (SiO2/SiO2-TiO2/TiO2) for silicon solar cells using a sol-gel technique. Sol. Energy Mater. Sol. Cells 2006, 90, 2710-2719. [CrossRef]

217. Fateh, R.; Dillert, R.; Bahnemann, D. Preparation and Characterization of Transparent Hydrophilic Photocatalytic TiO2/SiO2 Thin Films on Polycarbonate. Langmuir 2013, 29, 3730-3739. [CrossRef]

218. Ye, L.; Zhang, Y.; Zhang, X.; Hu, T.; Ji, R.; Ding, B.; Jiang, B. Sol-gel preparation of SiO2/TiO2/SiO2-TiO2 broadband antireflective coating for solar cell cover glass. Sol. Energy Mater. Sol. Cells 2013, 111, 160-164. [CrossRef]

219. Miao, L.; Su, L.F.; Tanemura, S.; Fisher, C.A.J.; Zhao, L.L.; Liang, Q.; Xu, G. Cost-effective nanoporous $\mathrm{SiO} 2-\mathrm{TiO} 2$ coatings on glass substrates with antireflective and self-cleaning properties. Appl. Energy 2013, 112, 1198-1205. [CrossRef]

220. Yao, L.; He, J.; Geng, Z.; Ren, T. Fabrication of mechanically robust, self-cleaning and optically high-performance hybrid thin films by SiO2\&TiO2double-shelled hollow nanospheres. Nanoscale 2015, 7, 13125-13134.

221. Lu, Z.; Chen, F.; He, M.; Song, M.; Ma, Z.; Shi, W.; Yan, Y.; Lan, J.; Li, F.; Xiao, P. Microwave synthesis of a novel magnetic imprinted $\mathrm{TiO} 2$ photocatalyst with excellent transparency for selective photodegradation of enrofloxacin hydrochloride residues solution. Chem. Eng. J. 2014, 249, 15-26. [CrossRef]

222. Lu, Z.; Zhou, W.; Huo, P.; Luo, Y.; He, M.; Pan, J.; Li, C.; Yan, Y. Performance of a novel TiO2 photocatalyst based on the magnetic floating fly-ash cenospheres for the purpose of treating waste by waste. Chem. Eng. J. 2013, 225, 34-42. [CrossRef]

223. Tao, C.; Zou, X.; Du, K.; Zhou, G.; Yan, H.; Yuan, X.; Zhang, L. Fabrication of robust, self-cleaning, broadband $\mathrm{TiO} 2 \mathrm{SiO} 2$ double-layer antireflective coatings with closed-pore structure through a surface sol-gel process. J. Alloy Compd. 2018, 747, 43-49. [CrossRef]

224. Mazur, M.; Wojcieszak, D.; Kaczmarek, D.; Domaradzki, J.; Song, S.; Gibson, D.; Placido, F.; Mazur, P.; Kalisz, M.; Poniedzialek, A. Functional photocatalytically active and scratch resistant antireflective coating based on $\mathrm{TiO} 2$ and SiO2. Appl. Surf. Sci. 2016, 380, 165-171. [CrossRef]

225. Spinelli, P.; Hebbink, M.; de Waele, R.; Black, L.; Lenzmann, F.; Polman, A. Optical Impedance Matching Using Coupled Plasmonic Nanoparticle Arrays. Nano Lett. 2011, 11, 1760-1765. [CrossRef]

226. Singh, Y.P.; Jain, A.; Kapoor, A. Localized Surface Plasmons Enhanced Light Transmission into c-Silicon Solar Cells. J. Sol. Energy 2013, 2013, 584283. [CrossRef]

227. Spinelli, P.; van Lare, C.; Verhagen, E.; Polman, A. Controlling Fano lineshapes in plasmon-mediated light coupling into a substrate. Opt. Express 2011, 19, A303-A311. [CrossRef]

228. Xu, R.; Wang, X.; Liu, W.; Song, L.; Xu, X.; Ji, A.; Yang, F.; Li, J. Optimization of the Dielectric Layer Thickness for Surface-Plasmon-Induced Light Absorption for Silicon Solar Cells. Jpn. J. Appl. Phys. 2012, 51, 042301.

229. Rao, J.; Varlamov, S.; Park, J.; Dligatch, S.; Chtanov, A. Optimization of Dielectric-Coated Silver Nanoparticle Films for Plasmonic-Enhanced Light Trapping in Thin Film Silicon Solar Cells. Plasmonics 2012, 8, 785-791. [CrossRef]

230. Li, H.-M.; Zhang, G.; Yang, C.; Lee, D.-Y.; Lim, Y.-D.; Shen, T.-Z.; Yoo, W.J.; Park, Y.J.; Kim, H.; Cha, S.N.; et al. Enhancement of light absorption using high-k dielectric in localized surface plasmon resonance for silicon-based thin film solar cells. J. Appl. Phys. 2011, 109, 093516. [CrossRef]

231. Cortes-Juan, F.; Chaverri Ramos, C.; Connolly, J.P.; David, C.; Garcia de Abajo, F.J.; Hurtado, J.; Mihailetchi, V.D.; Ponce-Alcantara, S.; Sanchez, G. Effect of Ag nanoparticles integrated within antireflection coatings for solar cells. J. Renew. Sustain. Energy 2013, 5, 033116. [CrossRef]

232. Liu, G.Q.; Liu, Z.Q.; Chen, Y.; Cai, Z.; Hu, Y.; Zhang, X.; Huang, K. Multi-band near-unity absorption and near-zero reflection of optical field in metal-dielectric-metal hybrid crystals. Sci. Adv. Mater. 2014, 6, 1099. [CrossRef] 
233. Sun, X.; Chen, X.; Zhang, Z.; Sun, Z. Plasmon based antireflection coatings containing nanostructured Ag and silica medium. Appl. Surf. Sci. 2012, 258, 3785-3788. [CrossRef]

234. Huang, X.; Lou, C.; Zhang, H.; Yang, H. Broadband anti-reflection in Si substrate via Ag nanospheres on Si nanopillar arrays. Opt. Commun. 2020, 460, 125133. [CrossRef]

235. Li, D.; Huang, F.; Ding, S. Sol-gel preparation and characterization of nanoporous $\mathrm{ZnO} / \mathrm{SiO} 2$ coatings with broadband antireflection properties. Appl. Surf. Sci. 2011, 257, 9752-9756. [CrossRef]

236. Salman, K.A.; Omar, K.; Hassan, Z. Effective conversion efficiency enhancement of solar cell using ZnO/PS antireflection coating layers. Sol. Energy 2012, 86, 541-547. [CrossRef]

237. Shim, B.-H.; Kang, J.-W.; Jeong, H.; Jeong, Y.; Kumar, T.P.; Jang, J.-H.; Park, S.-J. Enhanced efficiency of $\mathrm{Cu}(\mathrm{In}, \mathrm{Ga}) \mathrm{Se} 2$ solar cells with antireflection coating layers of MgF 2 and $\mathrm{ZnO}$ nanorods. Thin Solid Film 2016, 603, 103-107. [CrossRef]

238. Wuu, D.-S.; Lin, C.-C.; Chen, C.-N.; Lee, H.-H.; Huang, J.-J. Properties of double-layer Al2O3/TiO2 antireflection coatings by liquid phase deposition. Thin Solid Film 2015, 584, 248-252. [CrossRef]

239. Sharma, N.; Kumar, M.; Kumari, N.; Karar, V.; Sharma, A.L. Design and deposition of single and multilayer antireflection coatings of glass substrate using electron beam deposition. Mater. Today Proc. 2018, 5, 6421-6425. [CrossRef]

240. Rajvikram, M.; Leoponraj, S. A method to attain power optimality and efficiency in solar panel. Beni Suef Univ. J. Basic Appl. Sci. 2018, 7, 705-708. [CrossRef]

241. Zhang, W.-J.; Ma, D.-H.; Fan, Z.-Q.; Ma, X.-B.; Jiang, Z. Optimal design of quadruple-layer antireflection coating structure for conversion efficiency enhancement in crystalline silicon solar cells. Optik 2017, 177, 123-130. [CrossRef]

242. Kim, M.; Kang, T.-W.; Kim, S.H.; Jung, E.H.; Park, H.H.; Seo, J.; Lee, S.-J. Antireflective, self-cleaning and protective film by continuous sputtering of a plasma polymer on inorganic multilayer for perovskite solar cells application. Sol. Energy Mater. Sol. Cells 2019, 191, 55-61. [CrossRef]

243. Uzum, A.; Kuriyama, M.; Kanda, H.; Kimura, Y.; Tanimoto, K.; Ito, S. Non-Vacuum Processed Polymer Composite Antireflection Coating Films for Silicon Solar Cells. Energies 2016, 9, 633. [CrossRef]

244. Rajvikram, M.; Leoponraj, S.; Ramkumar, S. Enhancement of Solar Panel Efficiency with the Adoption of Antireflective Coating Techniques. J. Sci. Ind. Res. 2020, 79, 261-265.

245. Li, D.; Liu, Z.; Wang, Y.; Shan, Y.; Huang, F. Efficiency Enhancement of Cu(In,Ga)Se2 Solar Cells by Applying SiO2-PEG/PVP Antireflection Coatings. J. Mater. Sci. Technol. 2015, 31, 229-234. [CrossRef]

246. Kum, B.G.; Park, Y.C.; Chang, Y.J.; Jeon, J.Y.; Jang, H.M. Single-layered porous silica films on polyethylene terephthalate substrates for antireflection coatings. Thin Solid Film 2011, 519, 3778-3781. [CrossRef]

247. Yu, L.; Shearer, C.; Shapter, J. Recent Development of Carbon Nanotube Transparent Conductive Films. Chem. Rev. 2016, 116, 13413-13453. [CrossRef]

248. Barbero, D.R.; Stranks, S.D. Functional Single-Walled Carbon Nanotubes and Nanoengineered Networks for Organic- and Perovskite-Solar-Cell Applications. Adv. Mater. 2016, 28, 9668-9685. [CrossRef]

249. Liu, Y.; Wang, S.; Peng, L.-M. Toward High-Performance Carbon Nanotube Photovoltaic Devices. Adv. Energy Mater. 2016, 6, 1600522. [CrossRef]

250. Habisreutinger, S.N.; Nicholas, R.J.; Snaith, H.J. Carbon Nanotubes in Perovskite Solar Cells. Adv. Energy Mater. 2016, 7, 1601839. [CrossRef]

251. Anguita, J.V.; Ahmad, M.; Haq, S.; Allam, J.; Silva, S.R.P. Ultra-broadband light trapping using nanotextured decoupled graphene multilayers. Sci. Adv. 2016, 2, e1501238. [CrossRef]

252. Choi, Y.; Lee, J.; Seo, J.; Jung, S.; Kim, U.; Park, H. The effect of the graphene integration process on the performance of graphene-based Schottky junction solar cells. J. Mater. Chem. 2017, 5, 18716-18724. [CrossRef]

253. Kim, J.M.; Kim, S.; Shin, D.H.; Seo, S.W.; Lee, H.S.; Kim, J.H.; Jang, C.W.; Kang, S.S.; Choi, S.-H.; Kwak, G.Y.; et al. Si-quantum-dot heterojunction solar cells with $16.2 \%$ efficiency achieved by employing doped-graphene transparent conductive electrodes. Nano Energy 2018, 43, 124-129. [CrossRef]

254. De Nicola, F.; Hines, P.; De Crescenzi, M.; Motta, N. Moth-eye effect in hierarchical carbon nanotube anti-reflective coatings. Carbon 2016, 108, 262-267. [CrossRef]

255. De Nicola, F.; Salvato, M.; Cirillo, C.; Crivellari, M.; Boscardin, M.; Scarselli, M.; Nanni, F.; Cacciotti, I.; Crescenzi, M.D.; Castrucci, P. Record efficiency of air-stable multi-walled carbon nanotube/silicon solar cells. Carbon 2016, 101, 226-234. [CrossRef] 
256. George, Z.; Xia, Y.; Sharma, A.; Lindqvist, C.; Andersson, G.; Inganas, O.; Moons, E.; Muller, C.; Andersson, M.R. Two-in-one: Cathode modification and improved solar cell blend stability through addition of modified fullerenes. J. Mater. Chem. A 2016, 4, 2663-2669. [CrossRef]

257. Wang, Y.-C.; Li, X.; Zhu, L.; Liu, X.; Zhang, W.; Fang, J. Efficient and Hysteresis-Free Perovskite Solar Cells Based on a Solution Processable Polar Fullerene Electron Transport Layer. Adv. Energy Mater. 2017, 7, 1701144. [CrossRef]

258. Ginley, D.S.; Bright, C. Transparent Conducting Oxides. MRS Bull. 2000, 25, 15-18. [CrossRef]

259. Kılıç, Ç.; Zunger, A. Origins of Coexistence of Conductivity and Transparency in SnO2. Phys. Rev. Lett. 2002, 88, 095501. [CrossRef]

260. Deshmukh, H.P.; Shinde, P.S.; Patil, P.S. Structural, optical and electrical characterization of spray-deposited TiO2 thin films. Mater. Sci. Eng. B 2006, 130, 220-227. [CrossRef]

261. Zhang, S.; Yao, Y.; Hu, D.; Lian, W.; Qian, H.; Jie, J.; Wei, Q.; Ni, Z.; Zhang, X.; Xie, L. Application of Silicon Oxide on High Efficiency Monocrystalline Silicon PERC Solar Cells. Energies 2019, 12, 1168. [CrossRef]

262. Gangopadhyay, U.; Kim, K.; Mangalaraj, D.; Yi, J. Low cost CBD ZnS antireflection coating on large area commercial mono-crystalline silicon solar cells. Appl. Surf. Sci. 2004, 230, 364-370. [CrossRef]

263. Green, M.A.; Blakers, A.W.; Shi, J.; Keller, E.M.; Wenham, S.R. 19.1\% efficient silicon solar cell. Appl. Phys. Lett. 1984, 44, 1163-1164. [CrossRef]

264. Xu, Y.; Zhang, J.; Ai, L.; Lou, X.; Lin, S.; Lin, Y.; Fan, B.; Jin, J.; Song, W. Fabrication of mesoporous double-layer antireflection coatings with near-neutral color and application in crystalline silicon solar modules. Sol. Energy 2020, 201, 149-156. [CrossRef]

265. Minemoto, T.; Mizuta, T.; Takakura, H.; Hamakawa, Y. Antireflective coating fabricated by chemical deposition of ZnO for spherical Si solar cells. Sol. Energy Mater. Sol. Cells 2007, 91, 191-194. [CrossRef]

266. Gangopadhyay, U.; Jana, S.; Das, S.; Ghosh, P.; Mondal, A. Anti-reflective nano-composite based coating for crystalline silicon solar cells with noticeable significance. J. Renew. Sustain. Energy 2013, 5, 031607. [CrossRef]

267. Bowden, N.B.; Brittain, S.T.; Evans, A.G.; Hutchinson, J.W.; Whitesides, G.M. Spontaneous Formation of Ordered Structures in Thin Films of Metals Supported on an Elastomeric Polymer. Nature 1998, 393, 146-149. [CrossRef]

268. Pocivavsek, L.; Dellsy, R.; Kern, A.; Johnson, S.; Lin, B.; Lee, K.Y.C.; Cerda, E. Stress and Fold Localization in Thin Elastic Membranes. Science 2008, 320, 912-916. [CrossRef]

269. Kim, P.; Abkarian, M.; Stone, H.A. Hierarchical folding of elastic membranes under biaxial compressive stress. Nat. Mater. 2011, 10, 952-957. [CrossRef]

270. Kim, J.B.; Kim, P.; Pegard, N.C.; Oh, S.J.; Kagan, C.R.; Fleischer, J.W.; Stone, H.A.; Loo, Y.-L. Wrinkles and deep folds as photonic structures in photovoltaics. Nat. Photonics 2012, 6, 327-332. [CrossRef]

271. Li, R.; Yi, H.; Hu, X.; Chen, L.; Shi, G.; Wang, W.; Yang, T. Generation of diffraction-free optical beams using wrinkled membranes. Sci. Rep. 2013, 3, 2775. [CrossRef]

272. Li, Y.; Dai, S.; John, J.; Carter, K.R. Superhydrophobic Surfaces from Hierarchically Structured Wrinkled Polymers. ACS Appl. Mater. Interfaces 2013, 5, 11066-11073. [CrossRef] [PubMed]

273. Rhee, D.; Lee, W.-K.; Odom, T.W. Crack-Free, Soft Wrinkles Enable Switchable Anisotropic Wetting. Angew. Chem. 2017, 129, 6623-6627. [CrossRef]

274. Stafford, C.M.; Harrison, C.; Beers, K.L.; Karim, A.; Amis, E.J.; Vanlandingham, M.R.; Kim, H.-C.; Volksen, W.; Miller, R.D.; Simonyi, E.E. A buckling-based metrology for measuring the elastic moduli of polymeric thin films. Nat. Mater. 2004, 3, 545-550. [CrossRef] [PubMed]

275. Efimenko, K.; Rackaitis, M.; Manias, E.; Vaziri, A.; Mahadevan, L.; Genzer, J. Nested self-similar wrinkling patterns in skins. Nat. Mater. 2005, 4, 293-297. [CrossRef] [PubMed]

276. Basher, M.K.; Hossain, M.K.; Akand, M.A.R. Effect of surface texturization on minority carrier lifetime and photovoltaic performance of monocrystalline silicon solar cell. Optik 2018, 176, 93-101. [CrossRef]

277. Singh, P.K.; Kumar, R.; Lal, M.; Singh, S.N.; Das, B.K. Effectiveness of anisotropic etching of silicon in aqueous alkaline solutions. Sol. Energy Mater. Sol. Cells 2001, 70, 103-113. [CrossRef]

278. Macdonald, D.H.; Cuevas, A.; Kerr, M.J.; Samundsett, C.; Ruby, D.; Winderbaum, S.; Leo, A. Texturing industrial multicrystalline silicon solar cells. Sol. Energy 2004, 76, 277-283. [CrossRef]

279. Chen, W.-H.; Hong, F.C.-N. 0.76\% absolute efficiency increase for screen-printed multicrystalline silicon solar cells with nanostructures by reactive ion etching. Sol. Energy Mater. Sol. Cells 2016, 157, 48-54. [CrossRef] 
280. Feng, P.; Liu, G.; Wu, W.W.; Shi, Y.; Wan, Q. Improving the blue response and efficiency of multicrystalline silicon solar cells by surface nanotexturing. IEEE Electron Device Lett. 2016, 37, 306-309. [CrossRef]

281. Chen, W.-H.; Lin, H.-H.; Hong, F.C.-N. Improvement of conversion efficiency of multi-crystalline silicon solar cells using reactive ion etching with surface pre-etching. Thin Solid Film 2015, 597, 50-56. [CrossRef]

282. Prasad, B.; Bhattacharya, S.; Saxena, A.K.; Reddy, S.R.; Bedi, B.L.; Bhogra, R.K. Effect of self-masking, low-energy RIE texturization process on the performance of large-area multi-crystalline silicon solar cells. In Proceedings of the 22nd European Photovoltaic Solar Energy Conference and Exhibition, Milan, Italy, 3-7 September 2007; WIP Renewable Energies Press: Milan, Italy, 2007; pp. 1477-1479.

283. Slooff, L.H.; Kinderman, R.; Burgers, A.R.; Bakker, N.J.; van Roosmalen, J.A.M.; Buchtemann, A.; Danz, R.; Schleusener, M. Efficiency Enhancement of Solar Cells by Application of a Polymer Coating Containing a Luminescent Dye. J. Sol. Energy Eng. 2007, 129, 272. [CrossRef]

284. Kuang, Y.; van Lare, M.C.; Veldhuizen, L.W.; Polman, A.; Rath, J.K.; Schropp, R.E.I. Efficient nanorod-based amorphous silicon solar cells with advanced light trapping. J. Appl. Phys. 2015, 118, 185307. [CrossRef]

285. Nowak, R.-E.; Vehse, M.; Sergeev, O.; von Maydell, K.; Agert, C. ZnO nanorod arrays as light trapping structures in amorphous silicon thin-film solar cells. Sol. Energy Mater. Sol. Cells 2014, 125, 305-309. [CrossRef]

286. Sardana, S.K.; Chandrasekhar, P.S.; Kumar, R.; Komarala, V.K. Efficiency enhancement of silicon solar cells with vertically aligned $\mathrm{ZnO}$ nanorod arrays as an antireflective layer. Jpn. J. Appl. Phys. 2017, 56, 040305. [CrossRef]

287. Dong, W.; Huang, C.; Wei, T.; Zhang, Y.; Zhang, K.; Sun, Y.; Chen, X.; Dai, N. Nondestructively decorating surface textured silicon with nanorod arrays for enhancing light harvesting. Phys. Status Solidi A 2013, 210, 2542-2549. [CrossRef]

288. Liu, B.; Qiu, S.; Hu, R.; Liao, Y.; Chen, N.; Du, G. Multiscaled hierarchical nanostructures for enhancing the conversion efficiency of crystalline silicon solar cells. Appl. Surf. Sci. 2012, 259, 705-710. [CrossRef]

289. Chen, J.Y.; Sun, K.W. Growth of vertically aligned ZnO nanorod arrays as antireflection layer on silicon solar cells. Sol. Energy Mater. Sol. Cells 2010, 94, 930-934. [CrossRef]

290. Peranantham, P.; Park, G.H.; Kim, K.; Ahn, K.J.; Hwangbo, C.K.; Lee, J.; Rotermund, F. Efficiency Enhancement of a Single-Junction GaAs Solar Cell with ZnO Nanorod Arrays as an Antireflection Layer. J. Nanosci. Nanotechnol. 2017, 17, 4279-4282. [CrossRef]

291. Laube, M.; Rauch, F.; Ottermann, C.; Anderson, O.; Bange, K. Density of thin TiO2 films. Nucl. Instrum. Methods Phys. Res. Sect. B Beam Interact. Mater. Atoms 1996, 113, 288-292. [CrossRef]

292. Richards, B.S.; Rowlands, S.F.; Ueranatasun, A.; Cotter, J.E.; Honsberg, C.B. Potential cost reduction of buried-contact solar cells through the use of titanium dioxide thin films. Sol. Energy 2004, 76, 269-276. [CrossRef]

293. Repins, I.; Contreras, M.A.; Egaas, B.; DeHart, C.; Scharf, J.; Perkins, C.L.; To, B.; Noufi, R. 19.9\%-efficient $\mathrm{ZnO} / \mathrm{CdS} / \mathrm{CuInGaSe2solar}$ cell with 81.2\% fill factor. Progress in Photovoltaics. Res. Appl. 2008, 16, $235-239$.

294. Bhal Singh, C.; Bhattacharya, S.; Singh, V.; Balaji Bhargav, P.; Sarkar, S.; Bhavanasi, V.; Ahmad, N. Application of SixNy:Hz (SiN) as index matching layer in a-Si:H thin film solar cells. J. Renew. Sustain. Energy 2013, 5, 031605. [CrossRef]

295. Granqvist, C.G. Transparent conductors as solar energy materials: A panoramic review. Sol. Energy Mater. Sol. Cells 2007, 91, 1529-1598. [CrossRef]

296. Ellmer, K.; Klein, A.; Rech, B. (Eds.) Transparent Conductive Zinc Oxide: Basics and Applications in Thin Film Solar Cells; Springer: Berlin, Germany, 2008.

297. Lu, Y.; Zhang, X.; Huang, J.; Li, J.; Wei, T.; Lan, P.; Yang, Y.; Xu, H.; Song, W. Investigation on antireflection coatings for Al:ZnO in silicon thin-film solar cells. Optik 2013, 124, 3392-3395. [CrossRef]

298. Yang, W.; Yu, H.; Tang, J.; Su, Y.; Wan, Q.; Wang, Y. Omnidirectional light absorption in thin film silicon solar cell with dual anti-reflection coatings. Sol. Energy 2011, 85, 2551-2559. [CrossRef]

299. Addonizio, M.L.; Fusco, L.; Antonaia, A.; Cominale, F.; Usatii, I. Optimization of surface morphology and scattering properties of TCO/AIT textured glass front electrode for thin film solar cells. Appl. Surf. Sci. 2015, 357, 651-658. [CrossRef]

300. Dimroth, F.; Grave, M.; Beutel, P.; Fiedeler, U.; Karcher, C.; Tibbits, T.N.D.; Oliva, E.; Siefer, G.; Schachtner, M.; Wekkeli, A.; et al. Wafer bonded four-junction GaInP/GaAs//GaInAsP/GaInAs concentrator solar cells with 44.7\% efficiency. Prog. Photovolt. Res. Appl. 2014, 22, 277-282. [CrossRef] 
301. Zwerdling, S.; Wang, K.L.; Yeh, Y.C.M. High-Efficiency, Thin-Film GaAs Solar Cells. J. Sol. Energy Eng. 1983, 105, 237. [CrossRef]

302. Oh, G.; Kim, Y.; Lee, S.J.; Kim, E.K. Broadband antireflective coatings for high efficiency InGaP/GaAs/InGaAsP/InGaAs multi-junction solar cells. Sol. Energy Mater. Sol. Cells 2020, 207, 110359. [CrossRef]

303. Tsai, M.-T.; Yang, Z.-P.; Jing, T.-S.; Hsieh, H.-H.; Yao, Y.-C.; Lin, T.-Y.; Chen, Y.-F.; Lee, Y.-J. Achieving graded refractive index by use of $\mathrm{ZnO}$ nanorods/TiO 2 layer to enhance omnidirectional photovoltaic performances of InGaP/GaAs/Ge triple-junction solar cells. Sol. Energy Mater. Sol. Cells 2015, 136, 17-24. [CrossRef]

304. Leem, J.W.; Yu, J.S.; Kim, J.N.; Noh, S.K. Theoretical modeling and optimization of III-V GaInP/GaAs/Ge monolithic triple-junction solar cells. J. Korean Phys. Soc. 2014, 64, 1561-1565. [CrossRef]

305. Hou, J.-L.; Chang, S.-J.; Hsueh, T.-J.; Wu, C.-H.; Weng, W.-Y.; Shieh, J.-M. InGaP/GaAs/Ge triple-junction solar cells with ZnO nanowires. Prog. Photovolt. Res. Appl. 2012, 21, 1645-1652. [CrossRef]

306. Sertel, T.; Ozen, Y.; Baran, V.; Ozcelik, S. Effect of single-layer Ta2O5 and double-layer $\mathrm{SiO} 2 / \mathrm{Ta} 2 \mathrm{O} 5$ anti-reflective coatings on $\mathrm{GaInP} / \mathrm{GaAs} / \mathrm{Ge}$ triple-junction solar cell performance. J. Alloy Compd. 2019, 806, 439-450. [CrossRef]

307. Shi, E.; Li, H.; Yang, L.; Zhang, L.; Li, Z.; Li, P. Colloidal Antireflection Coating Improves Graphene-Silicon Solar Cells. Nano Lett. 2013, 13, 1776-1781. [CrossRef]

308. Lancellotti, L.; Bobeico, E.; Castaldo, A.; Delli Veneri, P.; Lago, E.; Lisi, N. Effects of different graphene dopants on double antireflection coatings/graphene/ $\mathrm{n}$-silicon heterojunction solar cells. Thin Solid Film 2018, 646, 21-27. [CrossRef]

309. Nakayama, K.; Tanabe, K.; Atwater, H.A. Plasmonic nanoparticle enhanced light absorption in GaAs solar cells. Appl. Phys. Lett. 2008, 93, 121904. [CrossRef]

310. Ilican, S.; Caglar, Y.; Caglar, M. Preparation and characterization of ZnO thin films deposited by sol-gel spin coating method. J. Optoelectron. Adv. Mater. 2008, 10, 2578-2583.

311. Yao, B.D.; Chan, Y.F.; Wang, N. Formation of ZnO nanostructures by a simple way of thermal evaporation. Appl. Phys. Lett. 2002, 81, 757-759. [CrossRef]

312. Cheng, A.-J.; Tzeng, Y.; Zhou, Y.; Park, M.; Wu, T.; Shannon, C.; Wang, D.; Lee, W. Thermal chemical vapor deposition growth of zinc oxide nanostructures for dye-sensitized solar cell fabrication. Appl. Phys. Lett. 2008, 92, 092113. [CrossRef]

313. Znaidi, L. Sol-gel-deposited ZnO thin films: A review. Mater. Sci. Eng. B 2010, 174, 18-30. [CrossRef]

314. Yeh, L.-K.; Lai, K.-Y.; Lin, G.-J.; Fu, P.-H.; Chang, H.-C.; Lin, C.-A.; He, J.-H. Giant Efficiency Enhancement of GaAs Solar Cells with Graded Antireflection Layers Based on Syringe like ZnO Nanorod Arrays. Adv. Energy Mater. 2011, 1, 506-510. [CrossRef]

315. Su, B.-Y.; Chu, S.-Y.; Juang, Y.-D.; Lin, M.-C.; Chang, C.-C.; Wu, C.-J. Efficiency Enhancement of GaAs Photovoltaics Due to Sol-Gel Derived Anti-Reflective AZO Films. J. Electrochem. Soc. 2012, 159, H312-H316. [CrossRef]

316. Jung, S.-M.; Kim, Y.-H.; Kim, S.-I.; Yoo, S.-I. Design and fabrication of multi-layer antireflection coating for III-V solar cell. Curr. Appl. Phys. 2011, 11, 538-541. [CrossRef]

317. Inomata, Y.; Fukui, K.; Shirasawa, K. Surface texturing of large area multicrystalline silicon solar cells using reactive ion etching method. Sol. Energy Mater. Sol. Cells 1997, 48, 237-242. [CrossRef]

318. Hovhannisyan, A.S. Single-layer antireflection coatings for GaAs solar cells. J. Contemp. Phys. 2008, 43, 136-138. [CrossRef]

319. Wu, J.; Makableh, Y.F.M.; Vasan, R.; Manasreh, M.O.; Liang, B.; Reyner, C.J.; Huffaker, D.L. Strong interband transitions in InAs quantum dots solar cell. Appl. Phys. Lett. 2012, 100, 051907. [CrossRef]

320. Xu, Y.; Zhang, B.; Hao Fan, W.; Wu, D.; Han Sun, Y. Sol-gel broadband anti-reflective single-layer silica films with high laser damage threshold. Thin Solid Film 2003, 440, 180-183. [CrossRef]

321. Wongcharee, K.; Brungs, M.; Chaplin, R.; Hong, Y.J.; Pillar, R.; Sizgek, E.J. Sol-gel processing by aging and pore creator addition for porous silica antireflective coatings. J. Sol Gel Sci. Technol. 2002, 25, $215-221$. [CrossRef]

322. Bautista, M.C.; Morales, A. Silica antireflective films on glass produced by the sol-gel method. Sol. Energy Mater. Sol. Cells 2003, 80, 217-225. [CrossRef]

323. Chen, C.-C.; Lin, D.-J.; Don, T.-M.; Huang, F.-H.; Cheng, L.-P. Preparation of organic-inorganic nano-composites for antireflection coatings. J. Non Cryst. Solids 2008, 354, 3828-3835. [CrossRef] 
324. Rezaei, N.; Isabella, O.; Vroon, Z.; Zeman, M. Optical optimization of a multi-layer wideband anti-reflection coating using porous MgF2 for sub-micron-thick CIGS solar cells. Sol. Energy 2019, 177, 59-67. [CrossRef]

325. Dahan, N.; Jehl, Z.; Hildebrandt, T.; Greffet, J.-J.; Guillemoles, J.-F.; Lincot, D.; Naghavi, N. Optical approaches to improve the photocurrent generation in $\mathrm{Cu}(\mathrm{In}, \mathrm{Ga}) \mathrm{Se} 2$ solar cells with absorber thicknesses down to $0.5 \mu \mathrm{m}$. J. Appl. Phys. 2012, 112, 094902. [CrossRef]

326. Shimazaki, K.; Imaizumi, M.; Kibe, K. SiO2 and $\mathrm{Al} 2 \mathrm{O} 3 / \mathrm{SiO} 2$ coatings for increasing emissivity of $\mathrm{Cu}(\mathrm{In}$, Ga)Se2 thin-film solar cells for space applications. Thin Solid Film 2008, 516, 2218-2224. [CrossRef]

327. Wakefield, G.; Adair, M.; Gardener, M.; Greiner, D.; Kaufmann, C.A.; Moghal, J. Mesoporous silica nanocomposite antireflective coating for $\mathrm{Cu}(\mathrm{In}, \mathrm{Ga}) \mathrm{Se} 2$ thin film solar cells. Sol. Energy Mater. Sol. Cells 2015, 134, 359-363. [CrossRef]

328. Moghal, J.; Kobler, J.; Sauer, J.; Best, J.; Gardener, M.; Watt, A.A.R.; Wakefield, G. High-Performance, Single-Layer Antireflective Optical Coatings Comprising Mesoporous Silica Nanoparticles. ACS Appl. Mater. Interfaces 2012, 4, 854-859. [CrossRef]

329. Moghal, J.; Reid, S.; Hagerty, L.; Gardener, M.; Wakefield, G. Development of single layer nanoparticle anti-reflection coating for polymer substrates. Thin Solid Film 2013, 534, 541-545. [CrossRef]

330. O'Regan, B.; Grätzel, M. A low-cost, high-efficiency solar cell based on dye-sensitized colloidal TiO2 films. Nature 1991, 353, 737-740. [CrossRef]

331. Roy-Mayhew, J.D.; Bozym, D.J.; Punckt, C.; Aksay, I.A. Functionalized Graphene as a Catalytic Counter Electrode in Dye-Sensitized Solar Cells. ACS Nano 2010, 4, 6203-6211. [CrossRef]

332. Zong, H.; Zhang, J.; Shi, G.; Li, Y.; Zhang, Q.; Wang, H. Directly grown anatase TiO2 films via liquid phase deposition as the photoanodes for dye-sensitized solar cells. Electrochim. Acta 2015, 179, 197-205. [CrossRef]

333. Chanta, E.; Bhoomanee, C.; Gardchareon, A.; Wongratanaphisan, D.; Phadungdhitidhada, S.; Choopun, S. Development of Anti-Reflection Coating Layer for Efficiency Enhancement of ZnO Dye-Sensitized Solar Cells. J. Nanosci. Nanotechnol. 2015, 15, 7136-7140. [CrossRef]

334. Chen, C.-N.; Wu, M.-J.; Hsu, C.-F.; Huang, J.-J. Antireflection coating of $\mathrm{SiO} 2$ thin film in dye-sensitized solar cell prepared by liquid phase deposition. Surf. Coat. Technol. 2017, 320, 28-33. [CrossRef]

335. Li, W.; Lv, F.; Shu, T.; Tan, X.; Jiang, L.; Xiao, T.; Xiang, P. Improving the performance of FTO conducting glass by $\mathrm{SiO} 2$ and $\mathrm{ZnO}$ anti-reflection films for dye-sensitized solar cells. Mater. Lett. 2019, 243, 108-111. [CrossRef]

336. Chanta, E.; Wongratanaphisan, D.; Gardchareon, A.; Phadungdhitidhada, S.; Ruankham, P.; Choopun, S. Effect of $\mathrm{ZnO}$ Double Layer as Anti-Reflection Coating Layer in ZnO Dye-Sensitized Solar Cells. Energy Procedia 2015, 79, 879-884. [CrossRef]

337. Li, W.; Tan, X.; Zhu, J.; Xiang, P.; Xiao, T.; Tian, L.; Yang, A.; Wang, M.; Chen, X. Broadband antireflective and superhydrophobic coatings for solar cells. Mater. Today Energy 2019, 12, 348-355. [CrossRef]

338. Tang, C.W. Two-layer organic photovoltaic cell. Appl. Phys. Lett. 1986, 48, 183-185. [CrossRef]

339. Na, S.-I.; Kim, S.-S.; Jo, J.; Oh, S.-H.; Kim, J.; Kim, D.-Y. Efficient Polymer Solar Cells with Surface Relief Gratings Fabricated by Simple Soft Lithography. Adv. Funct. Mater. 2008, 18, 3956-3963. [CrossRef]

340. You, J.; Dou, L.; Yoshimura, K.; Kato, T.; Ohya, K.; Moriarty, T.; Emery, K.; Chen, C.-C.; Gao, J.; Li, G.; et al. A polymer tandem solar cell with 10.6\% power conversion efficiency. Nat. Commun. 2013, 4, 1446. [CrossRef]

341. Zhao, W.; Li, S.; Yao, H.; Zhang, S.; Zhang, Y.; Yang, B.; Hou, J. Molecular Optimization Enables over 13\% Efficiency in Organic Solar Cells. J. Am. Chem. Soc. 2017, 139, 7148-7151. [CrossRef]

342. Green, M.A.; Hishikawa, Y.; Dunlop, E.D.; Levi, D.H.; Hohl-Ebinger, J.; Ho-Baillie, A.W.Y. Solar cell efficiency tables (version 51). Prog. Photovolt. Res. Appl. 2017, 26, 3-12. [CrossRef]

343. Kinoshita, T.; Fujishima, D.; Yano, A.; Ogane, A.; Tohoda, S.; Matsuyama, K.; Nakamura, Y.; Tokuoka, N.; Kanno, H.; Sakata, H.; et al. The approaches for high efficiency HIT solar cell with very thin $(<100 \mu \mathrm{m})$ silicon wafer over 23\%. In Proceedings of the 26th European Photovoltaic Solar Energy Conference, Hamburg, Germany, 5-9 September 2011; pp. 871-874.

344. Descoeudres, A.; Holman, Z.C.; Barraud, L.; Morel, S.; De Wolf, S.; Ballif, C. $>21 \%$ Efficient Silicon Heterojunction Solar Cells on n- and p-Type Wafers Compared. IEEE J. Photovolt. 2013, 3, 83-89. [CrossRef]

345. De Wolf, S.; Descoeudres, A.; Holman, Z.C.; Ballif, C. High-efficiency Silicon Heterojunction Solar Cells: A Review. Green 2012, 2, 7-24. [CrossRef] 
346. Zhang, D.; Digdaya, I.A.; Santbergen, R.; van Swaaij, R.A.C.M.M.; Bronsveld, P.; Zeman, M.; van Roosmalen, J.A.M.; Weeber, A.W. Design and fabrication of a SiOx/ITO double-layer anti-reflective coating for heterojunction silicon solar cells. Sol. Energy Mater. Sol. Cells 2013, 117, 132-138. [CrossRef]

347. Hussain, B.; Ebong, A.; Ferguson, I. Zinc oxide as an active n-layer and antireflection coating for silicon-based heterojunction solar cell. Sol. Energy Mater. Sol. Cells 2015, 139, 95-100. [CrossRef]

348. Samajdar, D.P. Light-trapping strategy for PEDOT:PSS/c-Si nanopyramid based hybrid solar cells embedded with metallic nanoparticles. Sol. Energy 2019, 190, 278-285.

349. Hu, D.; Liu, D.; Zhang, J.; Wu, L.; Li, W. Preparation and stability study of broadband anti-reflection coatings and application research for CdTe solar cell. Opt. Mater. 2018, 77, 132-139. [CrossRef]

350. Womack, G.; Kaminski, P.M.; Abbas, A.; Isbilir, K.; Gottschalg, R.; Walls, J.M. Performance and durability of broadband antireflection coatings for thin film CdTe solar cells. J. Vac. Sci. Technol. A Vac. Surf. Film 2017, 35, 021201. [CrossRef]

351. Beard, M.C.; Luther, J.M.; Semonin, O.E.; Nozik, A.J. Third Generation Photovoltaics based on Multiple Exciton Generation in Quantum Confined Semiconductors. Acc. Chem. Res. 2012, 46, 1252-1260. [CrossRef]

352. Wei, H.; Qiu, P.; Peng, M.; Wu, Q.; Liu, S.; An, Y.; He, Y.; Song, Y.; Zheng, X. Interface modification for high-efficient quantum dot sensitized solar cells using ultrathin aluminum nitride coating. Appl. Surf. Sci. 2019, 476, 608-614. [CrossRef]

353. Lay, T.S.; Lin, Z.H.; Chuang, K.Y.; Tzeng, T.E. InGaAs quantum dots-in-a-well solar cells with anti-reflection coating. J. Cryst. Growth 2019, 513, 6-9. [CrossRef]

354. Zhang, J.; Li, J.; Zheng, L.; Lu, Y.; Moulin, E.; Haug, F.-J.; Ballif, C.; Xu, H.; Dai, N.; Song, W. Simultaneous realization of light distribution and trapping in micromorph tandem solar cells using novel double-layered antireflection coatings. Sol. Energy Mater. Sol. Cells 2015, 143, 546-552. [CrossRef]

355. Agustín-Sáenz, C.; Machado, M.; Zubillaga, O.; Tercjak, A. Hydrophobic and spectrally broadband antireflective methyl-silylated silica coatings with high performance stability for concentrated solar applications. Sol. Energy Mater. Sol. Cells 2019, 200, 109962. [CrossRef]

356. Atwater, H.A.; Polman, A. Plasmonics for improved photovoltaic devices. Nat. Mater. 2010, 9, $205-213$. [CrossRef] [PubMed]

357. Enrichi, F.; Quandt, A.; Righini, G.C. Plasmonic enhanced solar cells: Summary of possible strategies and recent results. Renew. Sustain. Energy Rev. 2018, 82, 2433-2439. [CrossRef]

358. Catchpole, K.R.; Polman, A. Design principles for particle plasmon enhanced solar cells. Appl. Phys. Lett. 2008, 93, 191113. [CrossRef]

359. Catchpole, K.R.; Polman, A. Plasmonic solar cells. Opt. Express 2008, 16, 21793. [CrossRef]

360. Matheu, P.; Lim, S.H.; Derkacs, D.; McPheeters, C.; Yu, E.T. Metal and dielectric nanoparticle scattering for improved optical absorption in photovoltaic devices. Appl. Phys. Lett. 2008, 93, 113108. [CrossRef]

361. Zhang, D.; Yang, X.; Hong, X.; Liu, Y.; Feng, J. Aluminum nanoparticles enhanced light absorption in silicon solar cell by surface plasmon resonance. Opt. Quantum Electron. 2014, 47, 1421-1427. [CrossRef]

362. Zhang, Y.; Chen, X.; Ouyang, Z.; Lu, H.; Jia, B.; Shi, Z.; Gu, M. Improved multicrystalline Si solar cells by light trapping from Al nanoparticle enhanced antireflection coating. Opt. Mater. Express 2013, 3, 489. [CrossRef]

363. Spinelli, P.; Polman, A. Prospects of near-field plasmonic absorption enhancement in semiconductor materials using embedded Ag nanoparticles. Optics Express 2012, 20, A641. [CrossRef]

364. Wang, E.; White, T.P.; Catchpole, K.R. Resonant enhancement of dielectric and metal nanoparticle arrays for light trapping in solar cells. Opt. Express 2012, 20, 13226. [CrossRef]

365. Prabhathan, P.; Murukeshan, V.M. Surface Plasmon Polariton-coupled Waveguide Back Reflector in Thin-film Silicon Solar Cell. Plasmonics 2015, 11, 253-260. [CrossRef]

366. Lee, J.-Y.; Peumans, P. The origin of enhanced optical absorption in solar cells with metal nanoparticles embedded in the active layer. Opt. Express 2010, 18, 10078. [CrossRef] [PubMed]

367. Mendes, M.J.; Morawiec, S.; Mateus, T.; Lyubchyk, A.; Aguas, H.; Ferreira, I. Broadband light trapping in thin film solar cells with self-organized plasmonic nano-colloids. Nanotechnology 2015, 26, 135202. [CrossRef]

368. Stanley, C.; Mojiri, A.; Rosengarten, G. Spectral light management for solar energy conversion systems. Nanophotonics 2016, 5, 161-179. [CrossRef]

369. Van der Ende, B.M.; Aarts, L.; Meijerink, A. Near-Infrared Quantum Cutting for Photovoltaics. Adv. Mater. 2009, 21, 3073-3077. [CrossRef] 
370. Zhang, Q.Y.; Yang, C.H.; Pan, Y.X. Cooperative quantum cutting in one-dimensional (YbxGd1-x)Al3(BO3)4:Tb3+ nanorods. Appl. Phys. Lett. 2007, 90, 021107. [CrossRef]

371. Chen, D.; Wang, Y.; Yu, Y.; Huang, P.; Weng, F. Near-infrared quantum cutting in transparent nanostructured glass ceramics. Opt. Lett. 2008, 33, 1884. [CrossRef]

372. Chen, D.; Wan, Z.; Zhou, Y.; Zhong, J.; Ding, M.; Yu, H. Tuning into blue and red luminescence in dual-phase nano-glass-ceramics. J. Alloy Compd. 2015, 645, 38-44. [CrossRef]

373. Chen, D.; Wan, Z.; Zhou, Y.; Xiang, W.; Zhong, J.; Ding, M. Tuning into blue and red: Europium single-doped nano-glass-ceramics for potential application in photosynthesis. J. Mater. Chem. C 2015, 3, 3141-3149. [CrossRef]

374. Svrcek, V.; Yamanari, T.; Mariotti, D.; Mitra, S.; Velusamy, T.; Matsubara, K. A silicon nanocrystal/polymer nanocomposite as a down-conversion layer in organic and hybrid solar cells. Nanoscale 2015, 7, 11566-11574. [CrossRef]

375. Fukuda, T.; Kato, S.; Kin, E.; Okaniwa, K.; Morikawa, H.; Honda, Z.; Kamata, N. Wavelength conversion film with glass coated Eu chelate for enhanced silicon-photovoltaic cell performance. Opt. Mater. 2009, 32, $22-25$. [CrossRef]

376. Chen, W.; Hou, Y.; Osvet, A.; Guo, F.; Kubis, P.; Batentschuk, M. Sub-bandgap photon harvesting for organic solar cells via integrating up-conversion nanophosphors. Org. Electron. 2015, 19, 113-119. [CrossRef]

377. Tatsi, E.; Griffini, G. Polymeric materials for photon management in photovoltaics. Sol. Energy Mater. Sol. Cells 2019, 196, 43-56. [CrossRef]

378. Yablonovitch, E. Statistical ray optics. J. Opt. Soc. Am. 1982, 72, 899. [CrossRef]

379. Basu, P.K.; Khanna, A.; Hameiri, Z. The effect of front pyramid heights on the efficiency of homogeneously textured inline-diffused screen-printed monocrystalline silicon wafer solar cells. Renew. Energy 2015, 78, 590-598. [CrossRef]

380. Höhn, O.; Tucher, N.; Bläsi, B. Theoretical study of pyramid sizes and scattering effects in silicon photovoltaic module stacks. Opt. Express 2018, 26, A320. [CrossRef] [PubMed]

381. Alshal, M.A.; Allam, N.K. Broadband Absorption Enhancement in Thin Film Solar Cells Using Asymmetric Double-Sided Pyramid Gratings. J. Electron. Mater. 2016, 45, 5685-5694. [CrossRef]

382. Wang, K.X.; Yu, Z.; Liu, V.; Cui, Y.; Fan, S. Absorption Enhancement in Ultrathin Crystalline Silicon Solar Cells with Antireflection and Light-Trapping Nanocone Gratings. Nano Lett. 2012, 12, 1616-1619. [CrossRef]

383. Ma, H.; Wu, B.; Zhou, J.; Huang, H.; Xu, X.; Wang, C. Efficiency enhancement in ultrathin crystalline silicon solar cells with composite surface gratings. Opt. Commun. 2017, 393, 207-212. [CrossRef]

384. Zin, N.; McIntosh, K.; Bakhshi, S.; Vázquez-Guardado, A.; Kho, T.; Fong, K.; Stocks, M.; Franklin, E.; Blakers, A. Polyimide for silicon solar cells with double-sided textured pyramids. Sol. Energy Mater. Sol. Cells 2018, 183, 200-204. [CrossRef]

385. Hsu, W.-C.; Tong, J.K.; Branham, M.S.; Huang, Y.; Yerci, S.; Boriskina, S.V.; Chen, G. Mismatched front and back gratings for optimum light trapping in ultra-thin crystalline silicon solar cells. Opt. Commun. 2016, 377, 52-58. [CrossRef]

386. Guan, L.; Shen, G.; Liang, Y.; Tan, F.; Xu, X.; Tan, X.; Li, X. Double-sided pyramid texturing design to reduce the light escape of ultrathin crystalline silicon solar cells. Opt. Laser Technol. 2019, 120, 105700. [CrossRef]

387. Wangyang, P.; Wang, Q.; Hu, K.; Shen, X. Optical absorption enhancement of nanoconical frustum arrays texturing for c-Si film solar cells. Opt. Commun. 2014, 310, 19-24. [CrossRef]

388. Callahan, D.M.; Munday, J.N.; Atwater, H.A. Solar Cell Light Trapping beyond the Ray Optic Limit. Nano Lett. 2012, 12, 214-218. [CrossRef] [PubMed]

389. Konedana, S.S.P.; Vaida, E.; Viller, V.; Shalev, G. Optical absorption beyond the Yablonovitch limit with light funnel arrays. Nano Energy 2019, 59, 321-326. [CrossRef]

390. Wang, C.; Yu, S.; Chen, W.; Sun, C. Highly Efficient Light-Trapping Structure Design Inspired By Natural Evolution. Sci. Rep. 2013, 3, 1025. [CrossRef]

391. Saeta, P.N.; Ferry, V.E.; Pacifici, D.; Munday, J.N.; Atwater, H.A. How much can guided modes enhance absorption in thin solar cells? Opt. Express 2009, 17, 20975. [CrossRef]

392. Nielsen, K.H.; Kittel, T.; Wondraczek, K.; Wondraczek, L. Optical breathing of nano-porous antireflective coatings through adsorption and desorption of water. Sci. Rep. 2014, 4, 6595. 
393. Toth, S.; Muller, M.; Miller, D.C.; Moutinho, H.; To, B.; Micheli, L.; Linger, J.; Engtrakul, C.; Einhorn, A.; Simpson, L. Soiling and cleaning: Initial observations from 5-year photovoltaic glass coating durability study. Sol. Energy Mater. Sol. Cells 2018, 185, 375-384. [CrossRef]

394. Ábrahám, A.; Kócs, L.; Albert, E.; Tegze, B.; Szolnoki, B.; Nagy, N.; Safran, G.; Basa, P.; Hórvölgyi, Z. Durability of microporous hybrid silica coatings: Optical and wetting properties. Thin Solid Films 2020, 699, 137914. [CrossRef]

395. Zhang, J.; Ai, L.; Lin, S.; Lan, P.; Lu, Y.; Dai, N.; Tan, R.; Fan, B.; Song, W. Preparation of humidity, abrasion, and dust resistant antireflection coatings for photovoltaic modules via dual precursor modification and hybridization of hollow silica nanospheres. Sol. Energy Mater. Sol. Cells 2019, 192, 188-196. [CrossRef]

396. Guiheneuf, V.; Delaleux, F.; Pouliquen, S.; Riou, O.; Logerais, P.-O.; Durastanti, J.-F. Effects of the irradiance intensity during UV accelerated aging test on unencapsulated silicon solar cells. Sol. Energy 2017, 157, 477-485. [CrossRef]

397. Bouraiou, A.; Hamouda, M.; Chaker, A.; Neçaibia, A.; Mostefaoui, M.; Boutasseta, N.; Ziane, A.; Dabou, R.; Sahouane, N.; Lachtar, S. Experimental investigation of observed defects in crystalline silicon PV modules under outdoor hot dry climatic conditions in Algeria. Sol. Energy 2018, 159, 475-487. [CrossRef]

398. Vicente, G.S.; Bayon, R.; Morales, A. Effect of Additives on the Durability and Properties of Antireflective Films for Solar Glass Covers. J. Sol. Energy Eng. 2008, 130, 011007. [CrossRef]

399. Druffel, T.; Geng, K.; Grulke, E. Mechanical comparison of a polymer nanocomposite to a ceramic thin-film anti-reflective filter. Nanotechnology 2006, 17, 3584-3590. [CrossRef] [PubMed]

400. Heo, S.Y.; Koh, J.K.; Kang, G.; Ahn, S.H.; Chi, W.S.; Kim, K.; Kim, J.H. Bifunctional Moth-Eye Nanopatterned Dye-Sensitized Solar Cells: Light-Harvesting and Self-Cleaning Effects. Adv. Energy Mater. 2013, 4, 1300632. [CrossRef]

401. Leem, J.W.; Choi, M.; Dudem, B.; Yu, J.S. Hierarchical structured polymers for light-absorption enhancement of silicon-based solar power systems. RSC Adv. 2016, 6, 55159-55166. [CrossRef]

402. Kim, J.-J.; Lee, Y.; Kim, H.G.; Choi, K.-J.; Kweon, H.-S.; Park, S.; Jeong, K.-H. Biologically inspired LED lens from cuticular nanostructures of firefly lantern. Proc. Natl. Acad. Sci. USA 2012, 109, 18674-18678. [CrossRef]

403. Osbond, P. Plasma sprayed anti-reflection coatings for microwave optical components. Adv. Mater. 1992, 4, 807-809. [CrossRef]

404. Guerrero-Lemus, R.; Vega, R.; Kim, T.; Kimm, A.; Shephard, L.E. Bifacial solar photovoltaics-A technology review. Renew. Sustain. Energy Rev. 2016, 60, 1533-1549. [CrossRef]

405. Cui, H.N.; Costa, M.F.; Teixeira, V.; Porqueras, I.; Bertran, E. Electrochromic coatings for smart windows. Surf. Sci. 2003, 532-535, 1127-1131. [CrossRef]

406. Liu, C.; Wang, S.; Zhou, Y.; Yang, H.; Lu, Q.; Magdassi, S.; Tay, C.Y.; Long, Y. Index-tunable anti-reflection coatings: Maximizing solar modulation ability for vanadium dioxide-based smart thermochromic glazing. J. Alloy Compd. 2018, 731, 1197-1207. [CrossRef]

407. Lee, M.-H.; Cho, J.-S. Better thermochromic glazing of windows with anti-reflection coating. Thin Solid Film 2000, 365, 5-6. [CrossRef]

(C) 2020 by the authors. Licensee MDPI, Basel, Switzerland. This article is an open access article distributed under the terms and conditions of the Creative Commons Attribution (CC BY) license (http://creativecommons.org/licenses/by/4.0/). 